\author{
UNIVERSIDADE DE SÃO PAULO \\ FACUldade DE Filosofia, LETRAS E CiÊNCIAS Humanas \\ DEParTamento de LETRas ClásSiCas E VERnáCUlas \\ Programa de PÓS-GRADUAÇÃo EM LiTERATURA BRASILEIRA
}

ARLINDO REBECHI JUNIOR

Glauber Rocha, ensaísta do Brasil

V. 1

São Paulo

2011 


\author{
UNIVERSIDADE DE SÃO PAULO \\ FACUldade DE FILOSOFIA, LETRAS E CIÊNCIAS HumanaS \\ DEParTamento de LETRAS ClásSiCAS E VERNÁCUlas \\ Programa de PÓS-GRADUAÇÃo EM LiTERATURA BRASILEIRA
}

\title{
Glauber Rocha, ensaísta do Brasil
}

[exemplar original]

Arlindo Rebechi Junior

Tese apresentada ao Programa de PósGraduação em Literatura Brasileira, do Departamento de Letras Clássicas e Vernáculas da Faculdade de Filosofia, Letras e Ciências Humanas da Universidade de São Paulo, para a obtenção do título de Doutor em Letras

Orientador: Prof. Dr. Antonio Dimas

V. 1

São Paulo

2011 
Rebechi Junior, Arlindo

Glauber Rocha, ensaísta do Brasil / Arlindo Rebechi Junior. - São Paulo:

Universidade de São Paulo / Faculdade de Filosofia, Letras e Ciências Humanas, 2011.

$x, 578 \mathrm{f} . ; 31 \mathrm{~cm}$.

\section{Orientador: Antonio Dimas}

Tese (doutorado) - USP / Faculdade de Filosofia, Letras e Ciências Humanas / Programa de Pós-Graduação em Literatura Brasileira, 2011.

Referências bibliográficas: f. 291-302

1. Glauber Rocha (1939-1981). 2. Ensaísmo. 3. Campo Intelectual. 4. Campo Cultural. 5. Produção Seriada. - Tese. I. Dimas, Antonio. II. Universidade de São Paulo, Faculdade de Filosofia, Letras e Ciências Humanas, Programa de PósGraduação em Literatura Brasileira. III. Título. 


\section{Folha de Aprovação}

Arlindo Rebechi Junior

\section{Glauber Rocha, ensaísta do Brasil}

Tese submetida ao Programa de Pós-Graduação em Literatura Brasileira, do Departamento de Letras Clássicas e Vernáculas da Faculdade de Filosofia, Letras e Ciências Humanas da Universidade de São Paulo, para a obtenção do título de Doutor em Letras.

Defesa em / 2011

Membros da banca examinadora: 
A todos os meus professores e professoras, muitos deles demonstraram-me que a sonata da vida deve ser a de um "homem bom". O meu respeito a todos eles.

À Crô, não seria fácil imaginar o percurso sem ela, quanto mais fazê-lo. 


\section{Agradecimentos}

Em geral, o preparo de uma tese é algo bastante solitário. Demanda do estudioso o tempo de reflexão, requer dele os vaivéns de um percurso sinuoso que parece infindável e ainda por cima, na maior parte dos casos, o coloca à margem de muitas coisas da vida prosaica. Tudo é uma questão de opção e gosto, eu diria. O fim de uma tese, todavia, revela outros dois lados deste trajeto: que o trabalho solitário não era tão solitário assim e que se, por um lado, nos deixou à margem de algo, por outro, nos colocou em interação penetrante com um mundo à parte que é a construção da própria tese - o mundo do seu objeto.

Sob todos esses aspectos, o momento de agradecimento de uma tese é o momento de uma explícita lembrança, em que o trabalho de pesquisa se mostra devedor de pessoas e instituições. É a demonstração social mais clara no fim do percurso de que a construção de conhecimento é uma marca coletiva, ainda que se pense, em falsos momentos, que só dependa de si mesmo. Na lembrança de pessoas e instituições, espero não ter se esquecido de nenhuma delas. No caso de um lapso involuntário, de antemão já faço minhas desculpas públicas. Vamos ao que interessa.

Agradeço às seguintes instituições e pessoas a elas vinculadas:

No Rio de Janeiro, a grandiosa Biblioteca Nacional (BN) mostrou-se de uma receptividade ímpar na acolhida e nela pude pesquisar material raro de jornais e revistas; de dentro da Divisão de Informação Documental (DINF), órgão responsável pela reprodução em microfilme e em arquivos digitais do material consultado da BN, sou especialmente grato ao serviço prestado por Maria Lizete dos Santos, que é também do quadro docente da Universidade Federal do Rio de Janeiro (UFRJ), do seu Departamento de Letras Neolatinas. Ainda na capital carioca, senti igual receptividade no Tempo Glauber, localizado no bonito casarão de Botafogo. Lá, pude notar que a prática escrita de Glauber ultrapassava em boa medida sua dedicação em tempo às filmagens de cinema. Desta instituição agradeço em especial D. Lúcia Rocha, mãe de Glauber e a maior das idealizadoras da conservação do material de pesquisa sobre o cineasta baiano no Brasil; estendo tal agradecimento aos demais familiares do artista baiano e aos funcionários que de lá me atenderam.

Na Bahia, em Salvador, os funcionários da Biblioteca Pública do Estado da Bahia, mais conhecida como Biblioteca Central, mostraram-se uma dedicação singular na conservação do 
material e no atendimento; infelizmente, são obrigados "a fazer das tripas coração" com os parcos recursos que eles dispõem.

De São Paulo, agradeço as instituições dentro da nossa universidade, sobretudo as bibliotecas que consultei material: Faculdade de Filosofia, Letras e Ciências Humanas (FFLCH), Escola de Comunicações e Artes (ECA), Faculdade de Administração e Economia (FEA) e Instituto de Estudos Brasileiros (IEB). Sou grato ainda aos funcionários do Departamento de Letras Clássicas e Vernáculas, em especial, a sempre simpática Dayane Esteves Nogueira.

Ainda nesta cidade, também foi imprescindível o trabalho de uma instituição: o Centro de Documentação e Pesquisa da Cinemateca Brasileira, que possui um dos mais importantes acervos sobre o cineasta - o Arquivo Glauber Rocha -, doado pelo titular em 1980. Junto com o Tempo Glauber, estas duas instituições são uma base segura para o pesquisador de manuscritos e de inéditos do cineasta baiano. $\mathrm{Na}$ Cinemateca, eu devo o ótimo atendimento à Anna Paula e à Viviane.

$\mathrm{Na}$ Universidade Estadual de Campinas (Unicamp), pude utilizar os serviços do Arquivo Edgard Leuenroth (AEL), ligado ao Instituto de Filosofia e Ciências Humanas (IFCH). Esta instituição possui ótimo acervo com consulta bastante facilitada aos pesquisadores. Da Pontifícia Universidade Católica de São Paulo (PUC-SP), sou grato ao serviço de digitalização de microfilmes por meio do seu Cedic.

À CAPES, pelo apoio financeiro imprescindível por meio de bolsa de doutorado no Programa de Excelência Acadêmica (Proex).

Agradeço ainda as pessoas que fizeram, de um jeito ou de outro, parte deste meu percurso intelectual:

Um agradecimento especial ao meu orientador: Antonio Dimas. Com peculiar humor e olhar sabido, soube conduzir a orientação na medida certa, oferecendo-me a liberdade necessária para minhas escolhas e para meu trajeto. Trata-se, sem sombra de dúvida, de um tipo de orientação que ultrapassa em larga escala os muros da nossa USP.

Em Bauru, tenho por lá bons companheiros. Marcelo Carbone, Marcelo Bulhões, Mauro Ventura foram amigos que fiz nos corredores do Departamento de Ciências Humanas, da Universidade Estadual Paulista (UNESP), instituição que estive como professor substituto quando ainda se iniciava esta pesquisa. Do escaldante centro-oeste paulista, ainda estão meus fieis confidentes: os grandes amigos de afinidades eletivas Jean Cristtus Portela e 
Matheus Nogueira Schwartzmann, sempre me recebendo com grande hospitalidade em Bauru.

Em São Paulo, a lista de amigos não é menor.

De forma muito gentil e com muita amizade, Fabrício Vieira conseguiu junto ao Banco de Dados da Folha de S. Paulo cópia de material de difícil acesso para minha pesquisa. À Márcia Morgan, sua esposa e minha amiga, eu também estendo os meus agradecimentos.

Aos amigos da USP e da revista Teresa fica a minha lembrança de agradecimento. Em especial, a Ricardo Souza de Carvalho (FFLCH-USP), pelas conversas sempre francas nos inúmeros cafés da nossa universidade; a Jefferson Agostini de Mello (EACH-USP), pela acolhida em dois oportunos momentos: no Programa de Aperfeiçoamento de Ensino (PAE), quando estive ao seu lado por um ano na unidade da USP Leste, a Escola de Artes, Ciências e Humanidades (EACH), e quando, sob sua coordenação de simpósio, pude apresentar e discutir parte de minha proposta de pesquisa na Abralic de 2008; a Ieda Lebensztayn (IEBUSP), sempre disposta com os amigos, foi uma das primeiras a ler minha proposta deste trabalho, ainda em sua gênese.

Ainda no mundo da universidade, meu reconhecimento a Benedito Veiga (UEFS), pela precisão na informação, conduzindo-me ao lugar certo pela capital baiana; à Fatimarlei Lunardelli (UFRGS), pesquisadora de cinema no Rio Grande do Sul, que, num gesto de imensa gentileza, conseguiu dirimir uma dúvida minha em relação a uma fonte de pesquisa raríssima; a André Luís Gomes (UnB), que, junto com seu grupo na Abralic de 2007, permitiu-me que discutisse um trabalho sobre um texto teatral de Glauber; ao professor Rubens Machado Jr. (ECA-USP), também estudioso do cineasta baiano, pelo seu interesse em discutir minha pesquisa em uma mesa na Sociedade Brasileira de Estudos de Cinema e Audiovisual (Socine), em 2009; aos professores Fabiana Buitor Carelli Marquezini (FFLCHUSP) e Maurício Cardoso (FFLCH-USP), que, com muita pertinência e inteligência, conduziram comentários bastante válidos durante o exame de qualificação desta tese; ao professor Ismail Xavier (ECA-USP), pelos apontamentos cheios de erudição em curso, em nível de pós-graduação, sobre crítica de cinema, que frequentei no primeiro semestre de 2007; à professora Cilaine Alves Cunha (FFLCH-USP), que no papel de coordenadora do nosso programa demonstrou transparência no uso de todos os recursos públicos, a ela e toda a comissão formada na época agradeço a liberação de verba para custeio tanto de parte de 
uma das minhas viagens à Bahia para pesquisa em arquivo como de parte dos gastos com microfilmagem de material na Biblioteca Nacional.

Aos meus familiares:

Aos Sr. Arlindo e Sra. Lourdes, meus pais, que me mostraram o mundo da escola pública, apresentando-me seu aspecto mais transformador: com este mundo vi a possibilidade de um filho de operário metalúrgico do $\mathrm{ABC}$ paulista ser conduzido para uma defesa de doutoramento; aos meus sogros, aos meus irmãos e cunhadas. Registro publicamente, o meu agradecimento ao meu irmão Robson Rebechi e seu filho, meu sobrinho Robinho, que, numa generosidade ímpar, ofereceram-me um auxílio propício em minha volta do exterior para que pudesse ter a tranquilidade de tocar as coisas da vida e da tese.

Por fim, para Claudia, uma companheira que sempre esteve ao meu lado em todas as situações. Faz parecer que mais de uma década é coisa pouca. 
Compreender é primeiro compreender o campo com o qual e contra o qual cada um se fez.

Pierre Bourdieu, Esboço de auto-análise.

\section{O que Glauber quer?}

Fazer onda. Abrir bate-papo sobre assuntos sagrados. Demolir os figurões, os produtores boçais, os diretores comerciais, os exibidores ladrões. Discutir e achar que o cinema novo, $o$ cinema de autor, é o que vale. Tudo o que digo pode não ter importância um mês depois, mas na hora funciona. Sempre. [...]

A gente deve falar pouco, porém firme. Agora, se é para falar mesmo, tem que ser como mestre Villa: os violoncelos tudo doido, as trompas tudo alucinada, os tambores tudo correndo, os travelling, tudo montado sem continuidade. Geraldo Del Rey e (Antônio) Pitanga gritando, Waldemar no rodopio, o mar atlântico rebolando - de uma forma que quando a razão recusa, o coração aceita e perdoa. Não é assim no amor?

Glauber Rocha, em depoimento a Antônio Torres para a revista Finesse, em 1964. 


\section{Sumário}

\section{Volume 1 [estudo]}

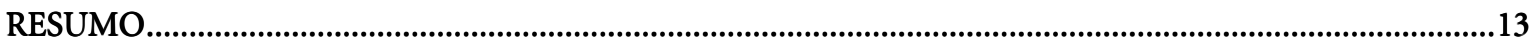

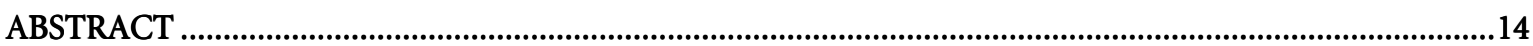

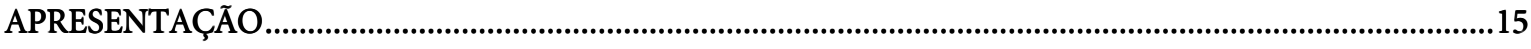

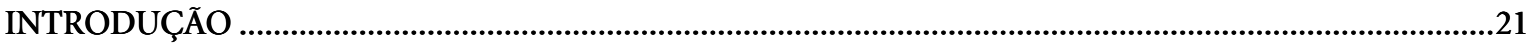

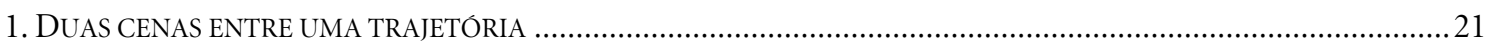

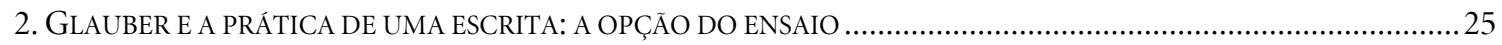

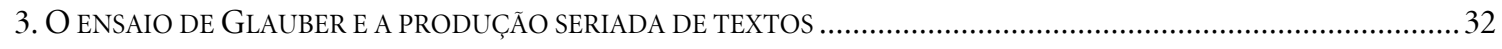

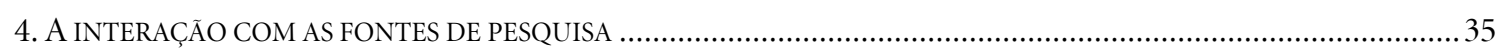

I. O ENSAÍSTA EM FORMAÇÃO. O ESTUDANTE ENTRE 1957-1959 …………………………………..........39

1. OS JOVENS DE MAPA: “EDITAR OS MAIS NOVOS SOBRETUDO, OS MAIS VELHOS NA MEDIDA DO POSSÍVEL E DO JUSTO"

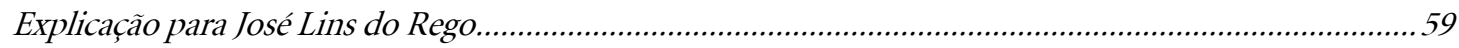

Visão sobre $o$ Western e a lição do filme mexicano ................................................................................ 74

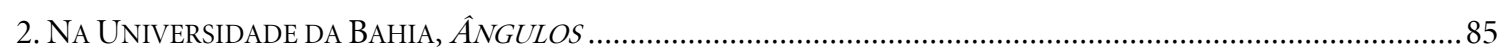

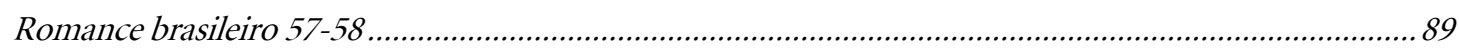

Da cinestética ao filme experimental ............................................................................................ 99

II. O ENSAÍSTA EM FORMAÇÃO. O PROFISSIONAL NA IMPRENSA ENTRE 1958-1962.........................108

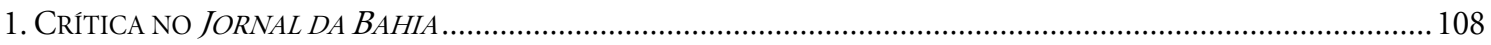

Do repórter de polícia à crítica na coluna "Jornal do Cinema" ............................................................ 112

Disseminação das ideias nacionais pelo cinema: defesa da arte dos moços na Bahia ............................. 122

2. A UM PASSO DO RIO, CRÍTICA NO DIÁRIO DE NOTÍCIAS ................................................................................. 135

Por ideias locais no Suplemento Artes e Letras .................................................................................... 136

O espaço do Suplemento Artes e Letras e a gênese para um manifesto.................................................. 148

III. A PRÁTICA DO ENSAIO DE IDEIAS E A CONFIRMAÇÃO DA CONSAGRAÇÃO....................................158

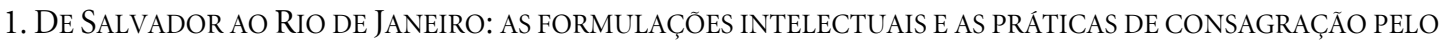

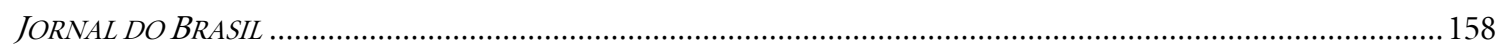

O jovem intelectual do cinema dá as caras no Rio de Janeiro............................................................ 168

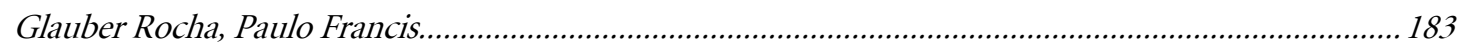

2. PrÁtICA DE CONSAGRAÇ̃̃o PELO LIVRO REVISÃ O CRÍTICA DO CINEMA BRASILEIRO ....................................... 193

Militância e liderança, pari passu.................................................................................................. 197

O gesto literário: por uma crítica do intelectual empenhado............................................................206 
3. GLAUbER AQUi DE DENTRO E LÁ DE FORA, UM HOMEM SEM PROFISSÃO: ESPECIAL PARA O PASQUIM .............216

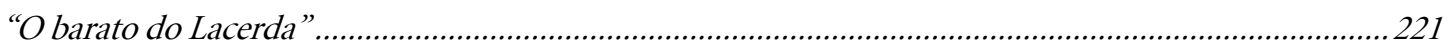

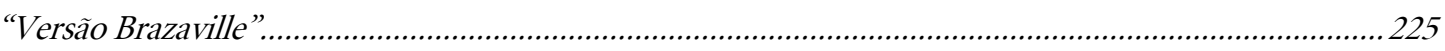

IV. O ENSAÍSMO DE GLAUBER NA VOLTA AO BRASIL ...................................................................231

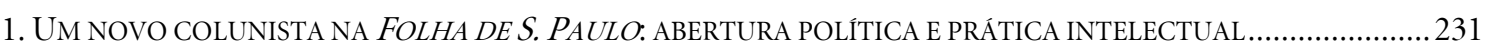

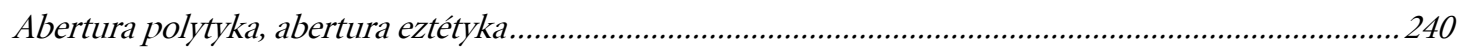

Intelectuais à brasileira por Glauber ou alguma coisa que veio de Iracema até Macunaíma ....................259

2. A ORGANIZAÇÃO PROGRAMÁTICA DO LIVRO REVOLUÇÃO DO CINEMA NOVO: ISOLAMENTO E TENTATIVA DE

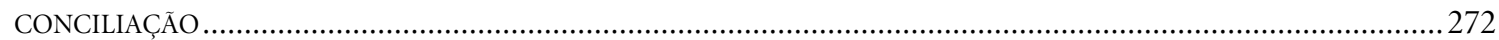

Prefácios, Américas e outras trajetórias .............................................................................................2280

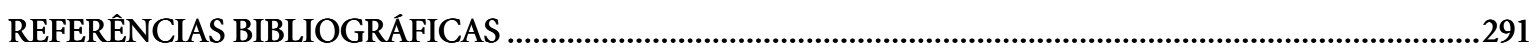

\section{Volume 2 [apêndice]}

1. Kynoperzpektyva Glauber Rocha: seleção de textos

2. Quadro das publicações

3. Um mapa cronológico para Glauber Rocha .573 


\section{Resumo}

REBECHI JUNIOR, Arlindo. Glauber Rocha, ensaísta do Brasil. 2011. 2 v. Tese (Doutorado em Letras - Literatura Brasileira) - Faculdade de Filosofia, Letras e Ciências Humanas, Universidade de São Paulo, São Paulo, 2011.

Glauber Rocha (1939-1981), conhecido principalmente pelo seu trabalho de cineasta e como um dos expoentes do Cinema Novo, atuou em diversos cenários da nossa intelectualidade e da cultura nacional. Este trabalho examina a prática ensaística deste intelectual manifestada em sua produção escrita que circulou na grande imprensa, nos veículos alternativos, em revistas literárias e culturais e em livros, entre o final dos anos 1950 e início dos anos 1980. Como método, privilegia-se a análise do seu trajeto intelectual em convivência com a análise de sua prática do ensaio de ideias sob a forma de divulgação seriada. Por esta intersecção, foi possível apreender: os movimentos de Glauber pelo campo cultural brasileiro em distintos períodos; sua visão, cheia de mobilidades, sobre os temas nacionais e culturais mais variados; e as estratégias disseminadas em seus escritos de ensaio que revelam o seu processo de consagração e rejeição diante de seus pares contemporâneos, no contexto cultural e intelectual de suas experiências de artista e crítico.

Palavras-Chave: Glauber Rocha (1939-1981); Ensaísmo; Campo Literário; Campo Intelectual; Produção Seriada. 


\section{Abstract}

REBECHI JUNIOR, Arlindo. Glauber Rocha, essayist of Brazil. 2011. 2 v. Thesis (PhD Brazilian Literature) - School of Philosophy, Literature and Human Sciences, University of São Paulo, São Paulo, 2011.

Glauber Rocha (1939-1981), Brazilian filmmaker and exponent of Cinema Novo, has acted in several contexts of the intelligentsia and culture of Brazil. This thesis examines his essay's practice manifested in their written production that circulated in the mainstream press, in the alternative media, in the literary and cultural magazines and books, between the late 1950s and early 1980s. The method which is used is interdisciplinary and includes two analytical perspectives: the intellectual trajectory of Glauber in harmony with the analysis of his essay's practice. In this thesis, we will discuss: the positions of the Glauber inscribed in the Brazilian cultural field at different times; his viewpoint of cultural and political practices in Brazil; and the strategies developed by Glauber, in his essay, that reveal his process of consecration and rejection in the cultural and intellectual context of his experiences as a Brazilian artist.

Keywords: Glauber Rocha (1939-1981); Essay; Literary Field; Intellectual Field; Press. 


\section{Apresentação}

Glauber Rocha (1939-1981) é reconhecido no campo cultural brasileiro pelos seus trabalhos em cinema entre as décadas 1960 e 1970. Autêntico polemista, ele ainda travou, tanto aqui como lá fora, diálogos com inúmeros representantes da literatura, do cinema, do teatro, da academia e do jornalismo.

Em outra via que não privilegiasse apenas o artista de cinema, este trabalho concentra seus estudos nos artigos de Glauber que circularam em periódicos da grande imprensa e da imprensa alternativa, em revistas literárias e culturais e em livros. No exame destes artigos, deu-se especial atenção aos seus possíveis diálogos com sua matriz geradora, suas práticas intelectuais, podendo-se, assim, tanto lançar comentários sobre o processo constituído de consagração e rejeição da figura intelectual de Glauber Rocha no campo literário e cultural brasileiro nos anos 1960 e 1970, como analisar sua concepção de Brasil construída por um pensamento político e intelectual heterogêneo, divulgado ao longo dos anos de suas contribuições em periódicos. Como hipótese central, levou-se em conta que sua prática escrita lançou mão da forma ensaística para a apreensão e análise dos problemas brasileiros de então. Daí, justificar-se o título deste trabalho: "Glauber Rocha, ensaísta do Brasil".

A ideia desta tese surgiu ainda em 2005, quando então eu voltava de uma viagem de mais de um ano da América do Norte, mais precisamente do Canadá. Impulsionado pelos seus filmes que lá havia revisto e pela leitura das novas edições de Revisão Crítica do Cinema Brasileiro e Revolução do Cinema Novo - até então raridades de sebo -, assim que coloquei meus pés em território brasileiro comecei a buscar por material escrito de Glauber que pudesse sugerir uma via profícua de trabalho para uma tese de doutoramento. Do contato que já havia feito com a fortuna crítica de Glauber, sabia da existência desse material, embora ainda não fosse capaz de dimensioná-lo.

Em 2006, em uma viagem de reconhecimento de terreno, estive na capital carioca para uma visita ao Tempo Glauber, no bairro do Botafogo. Em conversas anteriores ao meu ingresso no doutorado, Antonio Dimas - este que viria a ser o orientador deste trabalho sempre me alertava sobre a obrigatoriedade do pesquisador em investigar previamente as condições do local da pesquisa e propriamente as condições do material a ser pesquisado 
nesses arquivos. Um protocolo que merecia ser seguido antes do prosseguimento de qualquer projeto de fôlego. Bem recebido pelos que estavam à frente do acervo, pude dar conta do amplo material que foi coletado por Dona Lúcia - mãe de Glauber Rocha - antes e depois da morte de seu filho. Nesta e em outras visitas, certifiquei-me de uma produção extensa em fotografia, em áudio, em desenho e pintura, em manuscritos (tanto éditos como ainda inéditos), em artigos publicados em periódicos, sem contar o material de terceiros sobre Glauber Rocha e a biblioteca que pertenceu ao artista, cujas marginálias valorizavam cada exemplar de livro. Todo aquele material junto representava um mundo que se abria para pesquisadores interessados em Glauber Rocha. Para mim, não foi diferente.

Num primeiro momento, acreditei que podia concentrar meus esforços sobre o material manuscrito inédito do acervo e sobre os artigos publicados em periódicos. Enfeixava, naquelas circunstâncias, dois conjuntos de textos que eu achava serem complementares e, dessa forma, possíveis de serem trabalhados lado a lado.

Os manuscritos inéditos formavam um gradiente que se movimentava de romances de fôlego, com mais de 500 páginas, até a produção do ensaio de especulação filosófica, passando por uma ampla criação em poemas, uma extensa produção de contos e crônicas, autoria de textos teatrais, uma contumaz escrita de cartas, entre outras coisas. Enfim, verdadeiro oásis para pesquisadores com os pés na crítica genética e no fenômeno literário.

Em contato com seu material publicado, em especial seus artigos de periódicos, observei que muitos textos eram contundentes declarações de uma ação combativa de seu autor dentro do campo cultural brasileiro. O contato cada vez mais próximo com esse material mostrava-se, gradativamente, proveitoso e significativo, pois, a partir de leituras preliminares, já era possível levantar uma hipótese em torno daquela ação combativa presente nos artigos: ela também trazia consigo uma experiência de trabalho com a forma, o que me levava a dizer que aqueles textos eram também resultado de um experimento ensaístico de seu autor. A hipótese criava uma perspectiva possível de trabalho nas delimitações da literatura brasileira e alçava Glauber como uma figura que poderia ser relevante para os estudiosos dessa área. Dali em diante, decidimos que deveríamos deixar de lado, para o projeto da tese, os manuscritos inéditos e, realmente, depositar todos os esforços de pesquisa no material editado principalmente em periódicos. 
Tomada a decisão, surgiram os primeiros problemas. Embora o Tempo Glauber guardasse uma fatia representativa dos textos, nem sempre as condições das datações e da referência do material eram satisfatórias. Por diversos fatores, entre eles a provável pressa do seu autor em recortar e guardar o artigo de jornal ou mesmo as diversas equipes que passaram pelo acervo - cada uma delas deixando uma forma de organização do material-, datas e mesmo nomes de jornais foram presumidos. É comum, por exemplo, textos no acervo com apenas as indicações de ano. Diante disso, achei que seria mais honesto iniciar uma investida por arquivos, ir de jornal em jornal, de revista em revista, para confirmar datas, autorias de textos e, além disso, era a possibilidade de coletar novos materiais que poderiam não fazer parte de nenhuma hemeroteca, como era o caso do acervo do Tempo Glauber. Questão, esta última, que se confirmou na poeira dos arquivos.

Antes das primeiras visitas aos acervos, achei por bem fazer um escrupuloso levantamento na fortuna crítica do autor, agrupando todas as referências de textos de Glauber Rocha que encontrasse pela frente. O resultado foi um quadro com mais de 60 páginas em que se agrupavam todas as citações dos críticos de Glauber em relação aos seus artigos publicados durante a vida intelectual do autor em mais de duas décadas. Daquele ponto em diante, tornava-se possível presumir com mais precisão a dimensão prévia do trabalho a ser enfrentado na futura coleta. Com essa lista em mãos e demais referências obtidas no Tempo Glauber, tinha a certeza de que o trabalho nos arquivos poderia ser mais bem direcionado e, por conta disso, tornar-se mais exaustivo e seguro. Sabia de alguns acervos que guardavam parte das publicações que procurava e, assim, parti para eles. Comecei pelo mais óbvio, os acervos de periódicos da Universidade de São Paulo, nas diversas unidades (FFLCH, ECA, FEA e IEB). O próximo passo foi realizar uma visita ao acervo da Cinemateca Brasileira, no seu setor de documentação, onde também se guarda um valioso arquivo pessoal de Glauber. Lá, em alguns textos, constatei o mesmo problema do Tempo Glauber, ou seja, muitos artigos de hemeroteca não tinham uma confiável datação, portanto necessitavam de uma nova pesquisa para confirmações. Ainda na capital paulista, pude encontrar material publicado por Glauber na parte de documentação do Museu Lasar Segall, fechando assim minhas investidas na cidade.

Esgotadas as possibilidades em São Paulo, começava a etapa da pesquisa fora do estado, principalmente com o objetivo de buscar as publicações baianas e cariocas de que Glauber foi assíduo colaborador. 
Na Biblioteca Nacional, no Rio de Janeiro, localizei parte do material dos jornais baianos, com os textos de juventude de nosso autor, algumas revistas literárias e jornais cariocas em que ele, sobretudo nos anos 1960, colaborou. Como nem todo material estava em bom estado de conservação e parte dele, ainda por cima, estava inacessível, precisei complementar a pesquisa em arquivos baianos.

Meses depois, a partir das indicações feitas pelo pesquisador baiano Benedito Veiga, fui direto à Biblioteca Central da Bahia, em Salvador. Para minha sorte, os jornais de lá estavam em melhor conservação que o material do Rio de Janeiro. Completava-se, assim, com uma última investida pela capital soteropolitana, a coleta do material publicado por Glauber Rocha.

Ao final do levantamento em arquivos, confirmou-se um dado que prevíamos de modo ainda intuitivo no início dos trabalhos. Glauber produziu e publicou constantemente ao longo de sua vida intelectual. Os números dão uma ideia dessa extensão. Foram coletados e reproduzidos dos arquivos 702 textos de sua autoria.

Com o material em mãos e já organizado, comecei a divisão do trabalho. No primeiro volume da tese, além de uma introdução, o estudo a ser apresentado é composto de quatro capítulos mais complementos.

$\mathrm{Na}$ "Introdução" da tese, retomarei alguns pressupostos que circunscrevem meu desenho metodológico do trabalho e o problema central da tese - o estudo do que considero o ensaísmo de Glauber Rocha pelos seus textos seriados. Ali poderei expor o horizonte de problemas que minha abordagem levanta, tanto em termos históricos, já que este trabalho também acompanha e considera o percurso de formação intelectual de seu autor ao longo do tempo, como em termos críticos, na medida em que se propõe uma avaliação da sua prática escrita manifestada no ensaio. Somado a isso, também abordarei as dificuldades do trabalho crítico diante de um autor como Glauber Rocha, um representante não-canônico do campo literário nacional, e quais seriam os princípios de compreensão para se apreender sua experiência ensaística. Por fim, comento o meu trabalho de interação com as fontes de pesquisa.

No capítulo "I. O ensaísta em formação. O estudante entre 1957-1959", investigarei o trabalho inicial de busca de consagração pelo jovem Glauber Rocha, em Salvador, quando ainda é apenas conhecido pela sua atuação na crítica em periódicos baianos. Concentrarei a análise em duas publicações; na revista Mapa, organizada por ele e 
seus colegas; e na revista do grêmio da Faculdade de Direito, da Universidade da Bahia, e que se intitulou Angulos. Da primeira, vou me deter em três artigos mais longamente: "Romance de José Lins do Rego"; “O Western - uma introdução ao estudo do gênero e do herói”; e "Raices mexicanas de Benito Alazraki”. Da segunda, concentro meus comentários nos seguintes textos "Romance brasileiro 57"; "Velas - Calasans Neto e Paulo Gil"; "De cinestética"; "Filme experimental: um tempo fora do tempo".

No capítulo "II. O ensaísta em formação. O profissional na imprensa entre 19581962", analisarei sua atuação no Jornal da Bahia, publicação recém fundada na época e pela qual Glauber ajuda a constituir seu suplemento de cultura; no Diário de Notícias, principalmente pelos textos que ele publicou no Suplemento Artes e Letras. Do Jornal da Bahia, destacam-se em nosso estudo principalmente os seus textos publicados sobre cinema, entre eles: "Glória feita de sangue (I)"; "Glória feita de sangue (II)"; "As virgens de Salém (I)"; "Cinema nacional sabotado"; "Nota breve: o intelectual e o cinema"; "Indústria de cinema na Bahia”; “'Redenção” - primeiro filme baiano”; "Notas e comentários de cinema na Bahia"; "Rio, Zona Norte"; "Rio, Zona Norte (II)"; "Importância de Nelson Pereira dos Santos”. Do Diário, com todos os textos publicados dentro do Suplemento Artes e Letras, os destaques ficam por conta de: "reunião (E Sonia) 1"; "David \& Ubaldo \& Noenio"; "Inconsciência \& inconseqüência da atual cultura baiana"; "Eis a fogueira, poeta!"; "Sobre 'ângulos' \& outros bichos"; "Experiência 'Barravento': confissão sem moldura"; "Luz Atlântica, 1962”.

No capítulo "III. A prática do ensaio de ideias e a confirmação da consagração", prosseguirei o exame da busca de consagração pelo jovem crítico; analisarei suas formas de inserção no cenário carioca, tornando-se ele um assíduo colaborador do Suplemento Dominical do Jornal do Brasil, o que o levou, junto com sua atuação nos projetos de cinema da cidade, a ser reconhecido como um legítimo intelectual daquele cenário e representante de uma geração e líder de um grupo - os cinema-novistas. Em especial do Jornal do Brasil, destaco duas abordagens: sua estratégia muito bem sucedida de se ligar ao grupo de neoconcretos, que detinham as páginas do Suplemento Dominical, abrindo-lhe as portas deste jornal a partir de seu primeiro curta-metragem, Pátio; e sua estratégica polêmica com o consagrado crítico de teatro Paulo Francis, do Diário Carioca, em que a defesa do jovem crítico ultrapassa o dado provinciano e faz com que seja reconhecido no debate cultural mais amplo. Nesta mesma época, mais precisamente em 1963, Glauber publica seu primeiro livro, 
Revisão crítica do cinema brasileiro. Obra, esta, que examinarei o significado para sua militância e liderança no movimento do Cinema Novo. Tendo em vista sua consagração fora da Bahia, discutirei os possíveis significados de Glauber colocar um livro com aquelas características em circulação. Fechando o capítulo, examinarei suas colaborações com os veículos de comunicação alternativos, momento em que me detenho nas suas contribuições para o Pasquim. Modelares de sua forma de atuação no jornal carioca alternativo, destacamse os dois textos de minha abordagem: "O barato do Lacerda" e "Os mortos do primavera".

Por fim, no capítulo "IV.O ensaísmo de Glauber na volta ao Brasil”, retomarei os textos compostos na sua volta do exílio ao Brasil, com especial atenção para sua atuação como colunista na Folha de S. Paulo. Deste conjunto de textos, minha abordagem passa por dois pontos principais: a discussão empenhada por Glauber em torno da abertura política; e o perfil do intelectual exemplar que Glauber discute no periódico, cujo modelo ele remete ao escritor romântico José de Alencar, reavivando uma polêmica com Machado de Assis. Em paralelo, examinarei o processo de organização do seu livro mais famoso, o Revolução do Cinema Novo, cuja tônica descrevo ser entre o isolamento e sua tentativa frustrada de conciliação com o seu antigo grupo e sua memória de um passado dos anos 1960.

Em segundo volume, disponho ainda na tese o apêndice: uma "Kynoperzpektyva Glauber Rocha: seleção de textos” com aquilo que elegi como sua produção mais relevante para este estudo; um "Quadro das publicações" coletadas durante a pesquisa (resolvi registrar os textos de Glauber e de seus contemporâneos que pudessem interessar); "Um mapa cronológico para Glauber Rocha”, em que organizo um esquema para o que considero marcos de atuação e polêmicas em torno de alguns fatos da vida intelectual de Glauber 


\section{Introdução}

E a liberdade, em última análise, é o saber poder fazer. Basta de analisar o velho mundo. Vamos criar o novo mundo.

Glauber Rocha, em entrevista concedida a Paulo Francis [revista Status, 11 mar. 1975]

O ensaio procede, por assim dizer, metodicamente sem método. Theodor W. Adorno, "O ensaio como forma"

\section{Duas cenas entre uma trajetória}

Cena 1. Final da década de 1950, no trem que seguia de Maceió para o Recife, levava em um de seus vagões um homem velho e muito alto. Perto dele dois jovens em excursão por terras nordestinas. João Carlos Teixeira Gomes, companheiro de viagem do jovem Glauber Rocha, chama a atenção para o que parecia uma coincidência absurda. Aquele senhor poderia ser o reconhecido poeta Ascenso Ferreira. A dúvida inicial é resolvida pela resposta positiva à pergunta entre "assustadora e indiscreta" de um dos jovens ao senhor. Sim, era Ascenso, justamente no trem do Catende, "o trem do poema gostoso". O princípio indeciso da conversa, sem muitos jeitos e contornos dos rapazes, é quebrado pela lembrança do velho poeta: para surpresa geral, ele ligava os dois jovens à novata revista Mapa. Estabelecia, assim, a intimidade necessária. Na precisão correta do "timbre do sertão ou dos engenhos", Ascenso declamou fabulosamente, como era de sua praxe, "O trem de Alagoas" e outros tantos. Ascenso começou a falar de sua poesia, explicando-lhes sobre suas buscas sonoras e não propagandísticas. Ascenso com sua língua afiadíssima soltou aos jovens suas preferências: na poesia estão entre os grandes Drummond e Mário de Andrade, "João Cabral é bom mas eu não entendo a história da faca só lâmina", "gosto de Manuel Bandeira quando não faz besteira". Ascenso, aos sessenta e dois anos, com "força telúrica" e "graça folclórica", 
entoou a admiração entre os jovens artistas nordestinos. Todos seguiam danados "prá Catende"1 na companhia do poeta ${ }^{2}$.

Cena 2. Setembro de 1980. Em terras italianas, Glauber almejava o prêmio do Festival de Veneza. Carlo Lizzani, o diretor da mostra, diante de muitas expectativas, anuncia os vencedores do Leone d'Oro na entrevista coletiva. Desde 1968, Veneza não premiava os cineastas. Bastou que a notícia da exclusão da premiação de seu $A$ idade da terra circulasse para que começassem seus protestos cheios de discursos inflamados, algo entre a indignação e a raiva. Ali mesmo no saguão do Hotel Excelsior, Glauber encontrou Louis Malle, um dos premiados, e sem medir palavras deixa clara sua posição ao cineasta francês: "você ganhou o Leão de Ouro porque as cartas estavam marcadas, você venceu porque o seu filme foi produzido pela Gaumont, uma multinacional imperialista". Na sua cabeça, "Malle é um cineasta de segunda classe", e tal como os outros dois premiados - Cassavetes e Angelopoulos -, não faziam jus ao prêmio: “Ô Malle, [...] você realmente merece, não o Leão de Ouro, mas uma leoa de merda”. Pela Lido de Veneza, ele começa sua caminhada rumo ao Palazzo del Cinema, ponto principal do evento e onde poderia encontrar os membros do júri. Uma legião de jornalistas, maioria de italianos, o segue; alguns tomam notas, outros registram em audiovisual ou em fotografias a desenfreada irritação de Glauber. Em meio ao círculo desses homens e mulheres, o cineasta brasileiro começa seu discurso em seu italiano de pronúncia desajustada, intercalando o português com sotaque baiano:

"Uma premiação que foi, sob o meu ponto de vista, uma falta de respeito à
tradição intelectual. Por que dar um prêmio a Louis Malle - um cineasta de
segunda classe que faz filme comercial -, Cassavetes - um cineasta americano que
faz filme comercial com um rótulo de filme de vanguarda -, Angelopoulos...um
filme acadêmico ultrapassado? [Pausadamente] Tudo isso demonstra ignorância,
corrupção, racismo e falta de seriedade. Um descambo, uma sabotagem da
programação, da crítica (com jornais só falando dos filmes americanos e
franceses) e uma sabotagem do júri [...] Um júri absolutamente corrupto que
comete um erro grave... diplomático em relação à América Latina e em relação ao
Brasil. Farei uma campanha pra que se feche o escritório da Gaumont lá, pra que
se retalhe a RAI lá [...] O Festival de Veneza é muito bom para os franceses, é

\footnotetext{
${ }^{1}$ Glauber Rocha, "Com Ascenço no trem de Catende”, Diário de Notícias, Salvador (BA), 1957, s/p.

${ }^{2}$ Cf. Glauber Rocha, "Com Ascenço no trem de Catende", Diário de Notícias, Salvador (BA), 1957, s/p; João Carlos Teixeira Gomes, Glauber, esse vulcão, 1997, pp. 121-132; João Carlos Teixeira Gomes, "Ascenso e Bandeira esquecidos", em Camões contestador e outros ensaios, 1979.
} 
muito bom para os americanos, MAS NÃO PRA NÓS [ênfase]. Nós não somos estúpidos, nós conhecemos muito bem o cinema, a economia, a técnica e a política. A vergonha é de Veneza, o descambo é de Veneza, demonstrando sua decadência e o reacionarismo, incluindo a crítica italiana aqui. Vieram me massacrar, com uma coisa programada, uma vergonha. Eu sou a grande vítima desta intolerância. Eu não os respeito, porque meu filme é muito superior a esses. Meu filme fala do futuro, de um novo mundo, com uma ideologia e uma linguagem novas. MUITO MAIS QUE ESTA CRÍTICA DECADENTE QUE AMA LOUIS MALLE, A HITCHCOCK E A TUDO QUE ESTA MERDA QUE ESTÁ AÍ [já gritando]. Eu não ponho mais os pés em festival europeu e ainda farei uma campanha para que os latino-americanos não venham mais aqui...ou em Cannes. ESTÁ É UMA GUERRA DA CULTURA [em gritos]”³.

Anunciada a guerra, começava ele sua investida em direção aos responsáveis pela premiação. Glauber estava inconsolável, não suportava a falsa expectativa que Lizzani criara com o aceno do prêmio para $A$ idade da terra. De frente ao Palazzo, restava a Glauber lançar uma última ferroada altissonante: "Isto é um desrespeito à cultura, premiar um filme de Louis Malle... é uma vergonha. O Sr. George Stevens representa aqui o Pentágono! O Sr. Andrews Sarris representa a CIA! Os críticos que estão de acordo com esta premiação estão assinando a sua própria sentença de morte cultural. É um desrespeito com a tradição do cinema, com a Itália, a Itália de Rossellini, de Visconti. Isto não é possível”. Nada mais poderia ser feito. Nada. Triste e doente, o cineasta deixaria Veneza, logo depois de sua última performance pública no continente europeu. Morreria em menos de um ano ${ }^{4}$.

$$
* * *
$$

Em termos temporais, as duas cenas circunscrevem narrativas da vida intelectual de Glauber Rocha em pontas opostas: da juventude à fase adulta. Entre uma e outra ponta temporal, há uma via construída sob vários aspectos: por Glauber como artista e intelectual, por instituições e grupos que ele venha ter participado, por suas relações pessoais e

\footnotetext{
${ }^{3}$ Glauber Rocha, entrevista em Canal italiano RAI TER, 1980. [Depoimento]; Glauber Rocha em Sílvio Tendler, Glauber o Filme - Labirinto do Brasil (filme), 2003. [Depoimento].

${ }^{4}$ Cf. Glauber Rocha, em Pedro Del Pichia e Virginia Murano, Glauber, o leão de Veneza, 1982. [Depoimento]; Pedro Del Pichia, "Veneza dá os Leões, e Glauber faz comício", Folha de S. Paulo, São Paulo (SP), set. 1980, s/p; Paulo Francis, "Glauber, o leão de Veneza", Folha de São Paulo, São Paulo (SP), 19 set. 1980, p. 32; Louis Malle em Amir Labaki, "Memórias de uma geração", Folha de S. Paulo (suplemento Mais.), São Paulo (SP), 21 jan. 1996, p. 8. [Depoimento].
} 
profissionais. Em todas essas instâncias projetam-se seus discursos e suas experiências - seu trajeto intelectual de uma vida cheia de altos e baixos.

O aceno curioso de um jovem diante do representante de uma geração intelectual anterior caracteriza a primeira cena. Nas circunstâncias da dinâmica cultural nordestina, sobretudo, na dinâmica baiana, o encontro fortuito entre os jovens baianos e o velho poeta pernambucano serve para se estabelecer simbolicamente um limiar entre duas gerações - a do poeta já estabelecido, participante da vida agitada das revistas culturais do primeiro modernismo, e a dos jovens baianos, ainda de incipiente vida artística, procurando aliar formação intelectual com agitação cultural, numa Salvador bastante conservadora de então. Glauber nem sequer apresentava-se como promessa segura de uma nova geração. Tão somente começava a trilhar alguns caminhos de acesso ao seu admirável mundo.

$\mathrm{Na}$ segunda cena, as circunstâncias são outras. Glauber traz a carga de ser reconhecido e consagrado aqui e lá fora. Sua produção cinematográfica lista-se entre as mais importantes para o desenvolvimento do cinema mundial entre 1960 e 1970. É respeitado e goza de autoridade num grande espectro de intelectuais no mundo afora, ainda que estivesse ressentido com muitos deles. Em certa medida, Glauber aqui é promessa cumprida, cuja narrativa registra o fim de sua atuação, em desfecho melancólico de sua longa ação combativa.

Entre uma e outra cena, constitui-se não só o mundo simbólico de sua atuação, mas o espaço de possibilidades para uma trajetória. Significa dizer que, entre os marcos estabelecidos, há uma tortuosa linha que representa sua vida intelectual em várias dimensões: neste espaço convivem suas formas de relações pessoal e profissional; suas redes de sociabilidade; os processos que dão conta de suas primeiras inserções no campo cinematográfico e literário; as formas como ele estabeleceu seu percurso em direção ao primeiro emprego, ao primeiro filme produzido, aos primeiros juízos críticos recebidos; suas premiações e louvores recebidos em torno da recepção do seu trabalho artístico; as formas de rejeição de sua figura intelectual; as escolhas feitas por ele entre os gêneros de textos para que pudesse se processar seu trabalho artístico e crítico, entre tantas outras coisas possíveis. As cenas funcionam aqui, diante da vida intelectual de seu personagem, como demarcações. Estão nelas cristalizadas o início e o fim deste complexo movimento.

As duas cenas também esboçam um questionamento que se afunila para um problema de feição mais específica, cujo nosso interesse é imediato: será que Glauber, com 
uma trajetória intelectual tão rica, em que se fez a passagem do jovem curioso ao intelectual consagrado, embora ressentido, tenha em sua obra escrita uma manifestação tão vibrante dessa sua trajetória a se apreender, da mesma forma que sua obra de cinema possibilita? Em outras palavras, seria possível pela análise de sua produção escrita apreender as matizes dessa sua mesma trajetória intelectual? Convém saber o que extrair dessas possibilidades: que problema sua produção escrita aponta, que relação sua produção escrita pode gerar com sua trajetória e suas práticas intelectuais, que contribuições ela poderá gerar para sua fortuna crítica.

A tarefa, próxima de uma montagem de um quebra-cabeça, exige o exame mais apurado de todas essas questões em torno de sua prática escrita. A seguir, coloquemos nossas peças à mesa.

\section{Glauber e a prática de uma escrita: a opção do ensaio}

Certamente, a primeira face de Glauber Rocha a vir à tona é a do cineasta. E não é por menos. Por detrás dela vislumbra-se a força das suas imagens orquestradas por uma câmera: do sertão messiânico de Deus e o Diabo na Terra do Sol (1964); da tensão entre o mundo individualizado, internalizado do poeta, jornalista e militante Paulo Martins, e o mundo do seu confronto, cuja realidade conformista reina e domina o Estado entorpecido de Eldorado em Terra em Transe (1967); do “matador de cangaceiros” Antonio das Mortes, de O Dragão da Maldade contra o Santo Guerreiro (1969); da África de O leão de sete cabeças (Der Leone Have Sept Cabeças, 1970). E o que dizer do Di Cavalcanti construído em contexto fúnebre por Glauber, no Di (1977), e da figura de Cristo em A Idade da Terra (1980), além de tantos outros filmes e tantos outros personagens compostos pelo cineasta aqui e no exterior? A lista não para nestes exemplos e pode ser ainda espichada em um sem número de cenas e sequências captadas pela câmera nervosa que marcou a mise-en-scène de Glauber.

Aos olhos do público, incluídos aí os dos estudiosos, por seus filmes impõe-se uma cinematografia que, entre outras preocupações, quer entender o cinema com vistas à discussão dos parâmetros da identidade nacional. Com muita ambição, tal projeto de debate, em torno do homem brasileiro e de sua realidade, tornara-se cada vez mais demarcado depois 
do nosso primeiro modernismo por intelectuais de diferentes ramos. O saldo desse esforço convergia em linhagens de romances e ensaios que conviveram com diversas perspectivas da vida social brasileira. Alinhado a esta tradição, o cinema de Glauber dispunha, nesta mesma seara de preocupações, seu campo de maior visibilidade para sua crítica. Razão pela qual se justifica, em parte, a produção numerosa, em âmbito brasileiro e estrangeiro, de teses e livros em torno de Glauber Rocha cineasta e sua representação de um autêntico cinema voltado para os problemas de nossa formação.

Dito isso, não deixando de se compreender a relevância do cinema de Glauber e da crítica que ao redor dele gravita, convém salientar outro foco de possibilidades: seus escritos. O problema não é de hoje; já está disposto lá atrás.

Em 1963, em função das polêmicas geradas pela publicação do livro Revisão crítica do cinema brasileiro, de Glauber Rocha, o periódico Última Hora e a Fundação Cinemateca Brasileira promoveram um debate com alguns figurões da crítica e do cinema brasileiros de então. Interessa saber a opinião de um deles. Na ocasião, Paulo Emílio, então conservador da Cinemateca, deu uma declaração de penetrante alcance sobre o livro em debate e, mesmo anos depois, são palavras que ainda têm o mérito de nos expor as razões que justificam os estudos dos escritos de Glauber. Diz ele:

"O livro nos interessa porque nos interessamos pela personalidade dele [Glauber Rocha], sentimos que há uma personalidade criadora que tem importância no cinema brasileiro. O tal "autor" é o próprio G.R., porque digere tudo, faz o que bem entende das coisas, não toma conhecimento das coisas como elas são. De acordo com a personalidade afirmativa que ele tem, interpreta tudo à luz dos problemas que o estão preocupando no momento. Isso é importante para a gente sentir não só os limites, mas também o interesse do livro, de que forma pode ser um livro interessante e curioso, de que ângulo muito particular pode ser levado a sério". ${ }^{5}$

Décadas depois, Ivana Bentes, organizadora da importante obra da correspondência de Glauber Rocha, vai também apontar a relevância dos seus escritos. Por estes, visualizamos uma nova forma de abordagem de sua obra e, consequentemente, a lacuna que existe em sua fortuna crítica. Afirma, assim, Ivana Bentes:

\footnotetext{
${ }^{5}$ Paulo Emílio, "Debate sobre Revisão crítica do cinema brasileiro" [ Última Hora, São Paulo (SP), 9 nov. 1963, pp. 6-9], em Glauber Rocha, Revisão crítica do cinema brasileiro, 2003, p. 207.
} 
"Glauber não foi apenas um correspondente compulsivo, foi um escritor obsessivo, que passou mais tempo sobre a máquina de escrever que atrás de uma câmera. Ao nos defrontarmos com seus escritos, mais de quinhentas cartas, roteiros, poemas, ensaios, entrevistas, textos conceituais e confessionais, surge a pergunta decisiva: onde termina sua "obra" e até que ponto essa produção textual, de uma exuberância barroca, se integra a toda uma vida marcada pelo cinema? Diante desse sem-fim de papéis guardados ao longo de quase trinta anos, carregados em malas, pastas e baús pelos quatro cantos, numa errância nômade, outra questão se impõe: já é hora de tirar Glauber do "gueto" do cinema e inserilo na história da cultura e do pensamento contemporâneos, da qual o seu cinema faz parte". ${ }^{6}$

Entre uma declaração e outra, passaram-se mais de três décadas. Em 1963, Paulo Emílio estava ainda diante de um jovem cineasta, autor de apenas dois filmes - Barravento e Deus e o Diabo na terra do sol. Já Ivana Bentes, em final dos anos 1990, estava diante do já mitificado autor de Terra em transe e $A$ idade da terra. Mesmo que sejam estudiosos de diferentes épocas, um eixo, porém, parece comum às duas declarações: ambos entendem que os escritos de Glauber devam ser levados a sério para se descortinar a figura do intelectual de cultura brasileiro, que também é cineasta.

Não concentrar em seus discursos produzidos por seus filmes e assumir os escritos de Glauber Rocha como possibilidade de um detido estudo traz algumas implicações que precisam ser mais bem esmiuçadas aqui.

A primeira das implicações refere-se à própria postura que o pesquisador deverá ter diante do seu objeto. Escrevo algumas palavras sobre isso.

Todo campo de investigação delimita de modo particular seu objeto. Com Glauber e seus escritos não poderiam ser diferente. No conjunto formado por seus textos está contemplada uma multiplicidade de interações: dos escritos com Glauber, dos escritos com a recepção social destes, do escritor com outros intelectuais contemporâneos, com os grupos artísticos e com as instituições que ele se relaciona.

$\mathrm{Na}$ base de toda essa convivência, nem sem sempre pacífica, Glauber engrossa o coro daqueles que participam de uma vida literária e cultural de um tempo. Constituída de uma incessante aproximação e separação das ações e reações entre seus indivíduos, tal vida

\footnotetext{
${ }^{6}$ Ivana Bentes, "Introdução", em Glauber Rocha, Cartas ao mundo, 1997, p. 9.
} 
literária - em larga escala, tal como a própria sociedade - é um fenômeno cheio de dinamismos, constituído, sobretudo, pelas formas que assumem as motivações e os impulsos destes seus indivíduos. E com Glauber não foi diferente.

Ao investigar Glauber Rocha e seus escritos, neste campo de interação social, minha preocupação se volta para a forma pouco estável que é a própria dinâmica social em que está inserido o fenômeno literário. Nosso autor vivendo uma vida literária de um tempo assume para si uma forma literária que se torna, ao estudioso, um corpo observável. Por mais temerária que possa parecer, minha tarefa ante Glauber Rocha está enviesada justamente aí: convém observar tal vida social, incluindo nosso autor, interpretá-la e dar certa vida ao que se passou pelas mãos do escritor. Não uma vida completa, cheia de inteiras "verdades", mas uma vida constituída da observação e análise daquele que olha em retrospecto e assume, conscientemente, as contradições, as idas e vindas, o consenso e o conflito, típicos daquela vida literária de um tempo. Como crítico de Glauber, terei a favor aquilo que resistiu ao tempo, o que se cristalizou de uma prática escrita do escritor, aquilo que restou do seu fazer intelectual. Refiro-me aos seus escritos, sejam eles na forma que ganharam na divulgação seriada em periódico ou em sua forma menos perene, agrupados em livro.

Entre os pressupostos para uma abordagem do texto de um autor e intelectual como Glauber Rocha, minha primeira premissa está justaposta à relação que o analista está submetido ao tratar de um objeto tão dinâmico como um escritor e sua respectiva produção intelectual. O caso de Glauber é modelar. Deve-se compreender que seu escrito, assim como ocorre com todos os demais escritores, materializa uma prática intelectual que, comparativamente, sempre estará em conflito simbólico com os demais textos e práticas intelectuais em circulação num contexto cultural específico de um tempo e um espaço delimitados. Sem este entendimento, certamente, a tarefa passaria de uma análise crítica voltada para a busca de uma explicação que se poderia denominar como um dado sensível do escritor para um pobre entendimento de que os textos literários e a experiência sensível do escritor representam, longe de sua situação histórica de existência, tão somente uma qualidade inefável. Uma espécie de sublimação que só sugere uma visão idílica da arte, com seus cultores e mentores. Esta última, uma abordagem pouco profícua que apenas criaria mais uma aura em torno de Glauber e em nada poderia contribuir a sua fortuna crítica mais recente. 
Os escritos de Glauber e ele mesmo como intelectual de nossa cultura solicita do estudioso uma perspicácia ímpar. Trata-se, em outras palavras, de um discernimento que leve o pesquisador a prestar especial atenção às motivações do autor baiano em sua relação direta com o gosto de seu tempo, o que só vem demonstrar a permanente submissão da obra artística e crítica na aceitação e recusa dos valores de um tempo, e o modo como os jogos políticos e a perspectiva histórica são relevantes na compreensão do objeto estético, mesmo que tenhamos seu entendimento enquanto forma autônoma. Quando se pensa nos mecanismos de produção de textos para Glauber, a questão se afunila ainda mais, pois é necessário apreender sua luta travada, uma luta simbólica, por sinal, que acontece num território de grande disputa entre as formas de produção, circulação e consagração de obras e textos de intelectuais e artistas.

O problema, no nosso caso, poderia ser traduzido pelos cinco pontos seguintes:

1) os escritos de Glauber são constituídos também de suas práticas cotidianas, revelando-se neles uma forma tão viva e social quanto a vida daqueles que são os praticantes daquele cotidiano de onde o texto emerge historicamente. Saliente-se, no entanto, que o trabalho do crítico com seus escritos requer o cuidado de não projetar sempre as interpretações válidas para o Glauber cineasta como se fossem naturais ao Glauber escritor. Nem sempre a mesma validade de lá, do campo cinematográfico, pode ser útil e adequada para a compreensão de sua atuação no campo literário. Isso, porém, não quer dizer que interpretações e juízos corretos de seus leitores da obra cinematográfica não possam contribuir, por um dado informativo que seja, na compreensão do seu pensamento intelectual formalizado por sua escrita. A sobrevivência de uma boa interpretação sobre um Glauber voltado às práticas literárias trabalha no limite entre entender qual é o papel do homem do cinema no homem da literatura. Em contrapartida, entender o papel das práticas literárias para o homem do cinema. É evidente que o sucesso da empreitada (e seu risco) dependerá da dosagem que o estudioso fará na constituição do seu ponto de vista e de suas opções entre a escolha e a separação de uma ou outra coisa;

2) há em seus escritos a marca e o registro de suas lutas e adesões ao que é canônico e ao não-canônico. Sua consagração social, ou não, dependerá da intensidade de como estas marcas alimentam as experiências de recepção crítica ao longo dos tempos;

3) os escritos de Glauber estão submetidos a uma forma literária de seu tempo e podem trazer consigo um duplo movimento em relação aos impulsos de seu escritor. Ora 
assimila seu empenho "individual" de enfrentar o campo de forças presentes na vida social, demarcando na sua escrita o traço mais característico com que ele, o escritor, socializa-se com seus contemporâneos, com as obras e ideias contemporâneas e com a recepção crítica de obras de uma tradição literária e intelectual. Ora, em certo sentido, distancia-se deste empenho "individual" do escritor visto que a forma literária instituída caminha rumo à autonomização; neste caso, passando a refletir diretamente sobre as outras formas literárias e sociais de seu tempo;

4) quando pensamos no fenômeno literário do qual Glauber participa, pode-se compreender que toda prática cultural que dali surge opera dentro de um sistema linguístico, colocando em circulação sempre a apropriação e a reapropriação de ideias e valores linguísticos do seu tempo. Este ato de falar, que é derivado das próprias práticas culturais, traça uma rede de relações, contratos e dependências entre os indivíduos deste mesmo sistema linguístico, fundando uma percepção daquela experiência tanto em termos temporais (do presente de sua produção) como em termos espaciais (do lugar de onde surgem as ideias do texto literário e de seu modo de produção);

5) A prática literária de Glauber, assim como todas as outras, visa uma forma de cristalização perene de algo que se pode denominar como "material literário", sendo este uma forma substancial do aparecimento e da constatação de um campo literário em formação ou mesmo já formado. Neste material, já estão crivados as forças e os limites da vida social do intelectual; impossível, portanto, não haver nele marcas profundas de conflito, resignação, resistência e adequação de classe.

Colocadas todas essas implicações para a pesquisa dos escritos de Glauber, é momento de especificar a nuance de nossa abordagem.

Considerando que não seja uma característica exclusiva dele, veremos que o caso das práticas intelectuais em Glauber merece destaque, principalmente se pensarmos que estas práticas são geradoras de textos em diversos formatos, em diversas épocas e espaços, e são resultados das situações e circunstâncias das várias posições assumidas por Glauber no campo cultural brasileiro entre os finais dos anos 1950 e o início dos anos de 1980.

Glauber foi um intelectual de muita mobilidade em suas ações intelectuais e culturais. Esteve ambientado não só no Brasil, como participou de um amplo debate cultural no hemisfério norte. De uma ampla capacidade de adaptação às diversas experiências e circunstâncias que ele enfrentava, seus escritos refletem os passos dessas transformações. 
Dentre os vários formatos e experiências de textos que ele produziu, conduzimos nosso trabalho com base em seus textos ensaísticos. Ele encontrou na prática do ensaio o espaço adequado para a experiência de uma forma literária que, simultaneamente, tanto assimilasse seu empenho crítico em relação à vida social quanto assumisse sua condição e suas relações diante da sua posição de intelectual no campo cultural brasileiro de sua época. Somado à prática do cinema, o projeto intelectual e cultural de Glauber manifesta-se também na forma do ensaio.

Em outros termos, o ensaio (quem sabe seja bastante adequado falarmos ainda em experiência ensaística) de Glauber Rocha talvez seja a principal formalização de sua prática intelectual com a palavra, de sua atuação no campo de forças do próprio espaço social da literatura brasileira não-canônica. Por ora, sem entrar muito no mérito da questão, já que este será um trabalho inteiramente dedicado ao problema levantado, basta dizer que esta tese se debruçará exatamente sobre a prática ensaística, mais precisamente sobre a experiência ensaística de Glauber Rocha a partir de sua prática escrita representada, sobretudo, em seus textos publicados em periódicos. Nestes artigos de crítica e opinião, buscarei analisar duas questões centrais: 1) os recursos formais e de conteúdo que o escritor lançou mão como base de interpretação para a sua prática de escrita ensaística sobre a realidade brasileira. Neste caso, o propósito é apreender, dentro de sua trajetória intelectual e por meio dos seus escritos de ensaio, a mobilidade de sua visão sobre os temas nacionais e culturais mais variados, a depender ainda de suas estratégias e de suas posiçôes ocupadas no campo cultural brasileiro de então; 2) as estratégias presentes em seus escritos, a partir da forma do ensaio, que sugerem, em diferentes épocas e contextos, uma explicação sobre seu processo de consagração ou seu processo de rejeição como artista e intelectual brasileiro de forte atuação no contexto cultural dos anos 1960 e 1970, perante, obviamente, seus pares contemporâneos.

Com a focalização definida pela demarcação do pensamento intelectual de Glauber a partir do seu ensaio de ideias, optou-se por agrupar o material de pesquisa (seus escritos) em três grandes conjuntos de abordagem:

1) os escritos da atuação de Glauber Rocha na Bahia, em sua juventude. Trata-se de um conjunto que estabelece as bases para uma discussão em torno dos passos do ensaísta em formação. São ainda textos de experimentação da forma do ensaio e do tipo de interpretação a ser esboçada em termos metodológicos pelo seu autor; 
2) os escritos que marcam sua passagem de atuação intelectual em seu círculo local para uma atuação mais ampla, em contexto nacional, quando ele estabelece um diálogo maior com artistas consagrados e novatos do cenário nacional, em especial os artistas do Rio de Janeiro. Marca-se, na mesma época, o momento em que ele cada vez mais ganha um maior espaço no debate cultural e, como consequência, também se torna um intelectual muito mais consagrado em seu meio;

3) os escritos que registram sua experiência combativa da fase pós-exílio, a partir de 1976. Como intelectual já experiente e tomando para si todas as vivências e dessabores do exílio, Glauber acha que este é o momento mais adequado para lançar seus diversos balanços: dos períodos anteriores, dos acontecimentos para ele mais marcantes e das pessoas de afeto e desafeto.

Estes três grupos de escritos sustentam nosso desafio central: o estudo do seu percurso intelectual e ensaístico com prática escrita orquestrada pela forma do ensaio e o seu processo, nem sempre pacífico, de consagração como um dos grandes intelectuais e artistas brasileiros dos anos 1960 e 1970.

Convém a seguir, nos limites dessa proposta, esmiuçar as razões que colocam frente a frente a forma do ensaio em Glauber e a produção seriada de textos.

\section{O ensaio de Glauber e a produção seriada de textos}

Glauber foi, em todos os sentidos, um colaborador contumaz de jornais e revistas na imprensa brasileira e internacional. Quando não estava escrevendo um artigo, estava ele opinando em uma entrevista. Seus livros de não-ficção publicados em vida - Revisão crítica do cinema brasileiro e Revolução do cinema novo - são em parte a reconstituição desses seus lances e percursos de imprensa.

Pelas páginas dos textos seriados, ele mostrou-se um escritor ousado. Não porque havia desafiado - como de fato fez - críticos e artistas contemporâneos. Mas porque privilegiou o espaço desses veículos, fossem alternativos ou de grande circulação, para a manifestação de uma forma de texto: o ensaio de suas ideias e interpretações sobre nossa realidade artística e política. Não à toa, ele criou um movimento de duplo sentido. Sua experiência ensaística tornara-se dependente da sua produção seriada de textos, bem como 
esta também se ligava ao balão de ensaio vindo das transformações no calor das disputas intelectuais e de suas ideias fervilhantes.

Ao mesmo tempo em que Glauber tinha o desafio de escrever no jornal, num espaço convencionalmente considerado para ser consumido às pressas pelo leitor diário, ele mostrou-se com habilidade suficiente para considerar este espaço bastante propício para o ensaio de suas ideias, mesmo que assim fossem no calor dos acontecimentos ou no dia a dia. Tratado como documento das práticas de seu escritor, quase um diário do seu pensamento criador e intelectual, cada texto, no que trazia de ideias originais e problemas, ligava-se a outro e assim sucessivamente até se formular um mosaico cheio de interpretações verdadeira mostra da sua experiência de ensaísta.

Dentro de nossa proposta, os textos seriados de Glauber constituíram o escopo principal para a análise nesta tese, formulando-se, a partir deste material privilegiado, uma base para a reconstituição das representações do pensamento glauberiano de natureza política e cultural. $\mathrm{O}$ andamento da pesquisa mostrou que o conjunto de sua produção seriada, por acomodar o dado ensaístico sempre em transformação de seu autor, seria representativo também para o exame cronológico das etapas do seu pensamento intelectual, incluindo, por sua vez, suas mudanças de rumos, suas idiossincrasias, seus dilemas, suas contradições e ainda acertos analíticos.

Como hipótese, se a totalidade desses artigos indicava uma gênese a partir de uma experiência de aliança entre a prática cotidiana de seu autor e o arranjo criterioso das palavras para as páginas diárias dos jornais e revistas, foi ainda mais curioso notar que, quando colocados lado a lado, eles apresentavam-se como um quadro coerente para análise de sua prática escrita. Juntos, esses artigos sugeriam uma ideia central para o desenvolvimento deste trabalho: na mesma medida que seria possível deles extrair as visões da cultura nacional que Glauber havia acomodado por uma forma de ensaio de interpretação do Brasil e de suas realidades, também seria possível rastrear as formas pelas quais o intelectual passou na suas disputas de consagração e rejeição por se tornar reconhecido.

A experiência do ensaio de ideias na produção seriada dos textos de Glauber surge das contingências de sua vida intelectual atribulada. Daí, duas coisas se explicam da sua relação com os periódicos:

1) na juventude, os jornais e revistas vêm ao encontro de seus interesses pessoais e profissionais, tanto por se tratar de um espaço propício para a intensa divulgação de suas 
ideias, trazendo-lhe repercussões e vantagens imediatas localmente, como por se tratar de um espaço muito oportuno para sua própria formação em termos de prática escrita: naquele momento ele buscava, sem as certezas da vida madura, a melhor calibração interpretativa;

2) na sua fase mais madura, já nos anos 1970, os veículos escritos dos meios de comunicação de massa junto com a televisão eram os fenômenos de maior repercussão social entre as massas. É possível supor que, em relação aos meios impressos, nenhum outro meio lhe parecia ser tão eficiente para as propagações maciças de sua forma escrita e de suas ideias sempre em transformações. Se nesta época, ele via nos jornais um espaço adequado para praticar largamente uma escrita de ideias, por outro lado, parcela dos jornais que ele colaborou - sempre à procura de uma incessante renovação, algo próprio dos mecanismos da indústria cultural - talvez, no máximo, visse em Glauber um "cineasta exótico", um novo símbolo que poderia se tornar atração (talvez mercadológica) das páginas diárias do veículo.

De algum modo, esses artigos também passaram a funcionar como termômetro das suas intervenções políticas e estéticas no contexto da nossa cultura. Ao longo da coleta do material pesquisado para a composição da tese e nas suas posteriores leituras, notei que grande parte desses textos reportava-se ainda ao que chamei de uma experiência combativa, descrição da própria ação de seu autor que se fixou, sobretudo: na definição do que seriam as singularidades nacionais e locais; na forma de atuação do intelectual e do artista no campo cultural brasileiro e internacional; na divulgação massificada de um programa estético no qual ele era um dos mentores e difusores de ideias.

Cuidadoso e rigoroso, o crítico deve se preparar para os torneios e vaivéns que a fórmula de escrita glauberiana em uma produção seriada exige. Questões em forma e conteúdo que aparecem na juventude podem reaparecer, anos depois, como se fossem algo novo e de primeira ordem, quando na verdade é senão uma releitura de algo que o autor, sem meias palavras, pretende repisar e demarcar como território de seus problemas e suas certezas.

De nossa parte, o esforço demanda separar o joio do trigo, atentando-se para o conjunto que seus artigos formulam e como representam o seu pensamento, inclusive político, sobre a cultura brasileira em cada etapa de sua vida intelectual. 


\section{A interação com as fontes de pesquisa}

Desde o início, o levantamento do material de pesquisa sobre a produção seriada de textos de Glauber Rocha apresentou-se como um desafio quanto à sua realização. Sabíamos que uma procura de textos dispersos é sempre muito árdua e, muitas vezes, tornase uma atividade impossibilitada, já que nem sempre os arquivos em nosso país conseguem manter suas coleções em bom estado de conservação ou mesmo com todos os seus fascículos de maneira completa.

Não é raro ouvirmos certas histórias atormentadoras: de um jornal que fulano de tal levou para tal lugar e acabou por se extraviar. Tudo na maior naturalidade das coisas. Infelizmente, o pesquisador das coisas do Brasil não mais se surpreende quando se depara com jornais recortados ou com papéis que se dissolvem a cada mudança de página, dandolhe a impressão que será o último homem a ler aquele texto. No Brasil - de novo infelizmente -, ainda parecem bastante válidas as palavras de Jean-Michel Massa sobre as dificuldades de se pesquisar em nossos arquivos, por sinal ditas quase 40 anos atrás, na ocasião de seu original levantamento sobre Machado de Assis: "O pesquisador, antes de mais nada, deve transformar-se em bandeirante. Encontrar o que foi publicado já não é uma aventura fácil. As coleções são, com muita frequência, incompletas ou fragmentárias, às vezes dizimadas, o que retarda as pesquisas e as entrava. A mata passa à categoria de sertão de vegetação escassa. País jovem voltado para o futuro, o Brasil ainda não tem o devido respeito por seu passado"7.

Felizmente, se notarmos o saldo final de nossa pesquisa, nós veremos que, apesar de todas essas dificuldades inerentes, nosso levantamento não ficou impossibilitado e que a atividade nos arquivos de São Paulo, Rio de Janeiro e Bahia ocorreu de modo bastante satisfatório.

Como já havia adiantado em mais de uma vez, nossas fontes, em grande parte, encontram-se nos periódicos, em seus vários e distintos veículos. As contribuições de Glauber começaram antes mesmo que ele completasse seus 18 anos. O início de nossa coleta é com as revistas literárias e culturais de Salvador, das quais, em duas delas, ele foi um dos seus organizadores. Refiro-me aos dois veículos: Mapa, que ele organiza com seu grupo de amigos ainda do Colégio Central, e Angulos, revista do Centro Acadêmico Ruy Barbosa (CARB),

\footnotetext{
${ }^{7}$ Jean-Michel Massa, A juventude de Machado de Assis, 2009. p. 26.
} 
pertencente aos alunos da Faculdade de Direito da Universidade da Bahia, instituição que Glauber esteve por um curto período matriculado.

Da Bahia, foram ainda fontes imprescindíveis de pesquisa os jornais locais de final dos anos 1950 e início dos anos 1960. Detemo-nos em veículos de imprensa onde Glauber já havia se tornado um profissional. Coletaram-se do Jornal da Bahia seus textos da coluna "Jornal de Cinema" e outros escritos, em que se incluem suas manifestações sobre as políticas culturais locais e as manifestações tais como a literatura. A maior parte destes textos foi publicada entre 1958 e 1959. Da mesma forma, do Diário de Notícias, periódico que Glauber contribui por meio do Suplemento Artes e Letras, coletaram-se seus textos sobre cinema, políticas culturais locais e literatura.

Na imprensa carioca, Glauber formulou uma contribuição bastante valiosa para o Jornal do Brasil no início dos anos 1960. Os textos coletados deste veículo encontram-se quase que exclusivamente nas páginas do seu famoso Suplemento Dominical e tiveram relevância ímpar na medida que revelam sobre suas ideias no período inicial de sua inserção no Rio de Janeiro. Embora não abordado em seção específica na tese, fez parte desta coleta de textos da imprensa carioca, a coluna que Glauber manteve por pouco mais de um mês, no final do ano de 1964, no Diário Carioca. Da imprensa alternativa do Rio, também foi coletado material. Em especial, os textos do Pasquim. Tais textos de uma época, entre 1970 e 1977, em que Glauber já goza de bom destaque tanto aqui como lá fora, registram as marcas de várias passagens de suas experiências e embates durante o período.

Os anos finais de Glauber, parte importante para que se compreendam seus ressentimentos e suas ações de final de vida, revelam-se em colaborações constantes na imprensa nacional. Tornou-se relevante a coleta de sua coluna do suplemento Ilustrada, no jornal paulista Folha de S. Paulo; sua maior quantidade de contribuições é do ano de 1978. São textos importantes para nossa abordagem, pois neles Glauber torna-se mais do que nunca um crítico de ensaio político.

Por contribuir na reconstituição de sua vida intelectual, suas entrevistas desempenharam um papel central e tornaram-se uma fonte imprescindível, assim como suas cartas (remetidas e recebidas), para se captar uma experiência sua, fosse esta de fracasso, de consagração ou de um juízo mal recebido de outrem. As épocas e os veículos contemplados nestas entrevistas são os mais variados possíveis. Vão desde veículos de grande imprensa das grandes capitais do Brasil até revistas internacionais de todos os cantos. Onde houvesse um 
veículo disposto a ouvi-lo, Glauber não economizava nas palavras. Demonstrava-se por sempre longas páginas, das quais seus acervos ainda guardam originais, meticulosamente, alterados por ele, que sua disposição em oferecer um depoimento ultrapassava, muitas vezes, o espaço das próprias páginas ofertadas. Há casos em que seu longo depoimento deve ser contorcido na diagramação espremida das páginas ou casos em que sua entrevista ganha páginas extras, continuando em um próximo número do jornal ou da revista.

Seus livros, principalmente, Revisão... e Revolução..., foram fontes que registram o seu esforço intelectual em coletar aquilo que publicara no periódico para, assim, colocar em nova significação o seu material. Evidente que tal material torna-se ainda mais relevante na abordagem desta tese na medida em que, da parte de Glauber, estes textos também refletem uma postura comum e presente nos dois livros: ele não só coligiu tais textos, mas também buscou aliá-los a sua própria agenda de artista e intelectual e quando necessário ele fez com que os textos fossem arredondados nos retoques de sua caneta ou de sua máquina de escrever. Ainda no campo dos livros como fontes, foi obrigatório considerar sua fortuna crítica sob dois aspectos: as obras de conteúdo biográfico, muitas delas com clara mitificação do biografado, e os livros que tratavam de sua obra, estes em grande parte lidando com os aspectos do cinema glauberiano. Ainda em tempo: outros escritos que porventura fizeram parte deste nosso levantamento encontram-se na listagem completa de textos fotocopiados ou fotografados nos arquivos. Tal lista pode ser consultada no segundo volume desta tese.

Completa-se ainda o levantamento, uma última fonte de pesquisa, não menos importante: seus filmes em curta-metragem e longa-metragem, estejam eles sob o domínio do gênero documentário ou como obra de ficção. Embora a tese não se debruce sobre todos eles, colocando-os como objeto central de análise, eles não deixam de significar muito na trajetória intelectual de Glauber e são, portanto, parte indispensável para se ter acesso a sua forma de pensamento em diferentes épocas e ambientações. Como seus filmes, muitas vezes, são responsáveis por cristalizar posições políticas e estéticas do escritor e demonstram, embora de forma sempre esfumaçada, suas alianças no mundo intelectual, é preciso encarálos com certa ressalva. São filmes que sem descuidar de seu dado mais aparente de formalização de uma realidade nacional - e de uma visão sobre o Brasil - buscam, na mesma medida, dar vazão ao artista que se coloca como independente. 
Achei por bem esclarecer uma opção que se encontra na tese e que não deixa de ser também uma opção metodológica presente no estudo. Em nome do que se supõe ser uma leitura mais fluída do trabalho, optamos por não colocar em todo o estudo uma única nota de rodapé explicativa. As notas utilizadas aqui só remetem aos dados bibliográficos de eventuais citações presentes no texto ou de remissões de estudos que reiteram o dado informativo trazido a lume. Deliberadamente, a escolha acolhe um risco. Sem a opção de entrecortar a leitura com remissões, resta ao leitor apenas o texto principal e nada mais. Reitero: em nome de uma maior fluidez, achei que seria o caso de se arriscar. Restará saber a recepção disso.
\end{abstract}




\section{O ensaísta em formação. 0 estudante entre 1957-1959}

Você sabe que Bahia é terra de autodidatismo e muita raça, senão se vai por água abaixo.

Glauber Rocha, em carta a Adalmir da Cunha Miranda [Salvador, jul. 1957]

\section{Os jovens de Mapa: "editar os mais novos sobretudo, os mais velhos na medida do possível e do justo"}

A frase entre aspas foi extraída de um dos editoriais da revista cultural baiana Mapa e dá uma boa ideia do embate estabelecido na cidade de Salvador, no final dos anos 1950. De vida curta, Mapa circulou apenas em três números, entre 1957 e 1958. Foi, no entanto, o suficiente para lançar a plataforma dessa nova geração baiana: a necessidade da renovação do circuito artístico baiano pelos experimentos intelectuais dos mais jovens. Inserido nesse grupo de jovens que organizou Mapa estava Glauber Rocha. Em parte pelos estímulos lançados com a construção de Brasília e o plano de metas de Juscelino Kubitschek, em parte pelos estímulos vindos da repercussão dos experimentos de outros jovens de São Paulo, como o grupo dos Concretos, Glauber e seus companheiros demarcavam o território de suas ações como legítimos representantes da ideia reformista que pairava sob o país.

Embora a Bahia já houvesse experimentado sopros de modernizações artísticas caso da revista modernista Arco e Flexa, fundada em 1928, que perdurou com seus cinco números até 1929, e do grupo que organizou os exemplares de Caderno da Bahia, nos anos 1940 e 1950, e realizou o I Salão Baiano de Belas Artes, em 1949 -, dentro daquelas 
circunstâncias, os jovens de Mapa receberam novos impulsos com as movimentações políticas e institucionais do momento e, assim, puderam constituir uma proposta ambiciosa que ligasse irremediavelmente a renovação das artes baiana à própria geração formada no seio do novo ambiente de mudanças.

Não parece exagero aferir aquele momento como rodeado por uma atmosfera de mudanças. Em centros nordestinos, o governo do presidente Juscelino Kubitschek emplacava seu otimismo desenvolvimentista pela criação da Superintendência do Desenvolvimento do Nordeste (Sudene). A industrialização do petróleo na bacia do Recôncavo e seus seguidos investimentos formulavam uma crença cheia de esperanças numa nova etapa de real desenvolvimento econômico para o estado. Na capital baiana, a questão se traduzia nas tentativas e projetos elaborados pela Comissão de Planejamento Econômico (CPE), cujo resultado mais vistoso, nem por isso o mais bem sucedido, culminou com a elaboração do Plano de Desenvolvimento, o Plandeb, em 1959. Em Salvador, as mudanças tornaram-se visuais. A Superintendência de Urbanização da Capital (Surcap) e a prefeitura da cidade refizeram contornos urbanísticos, realocando hábitos e costumes de sua gente. No que toca a sua elite local, a cidade no seu dia a dia acumulava, refundia e disseminava o discurso modernizador daquele momento. Em termos políticos, a relação mais estreita de Juscelino com o então governador da Bahia Juracy Magalhães, ainda que fossem de partidos diferentes, oferecia a medida exata da proximidade entre aquilo que acontecia na capital federal e nas fronteiras baianas.

Glauber e seus companheiros de Mapa não ficariam incólumes a esse clima.

Parcela intelectual da vida baiana, da qual esses jovens eram parte, fazia crer que havia uma atmosfera para uma nobre missão. Nobre porque se tratava de uma renovação sem precedentes: o localismo da arte baiana - fechada em si mesma e ainda dependente das "velhas" formas - seria expurgado, conseguindo-se, enfim, alçar a arte baiana ao reconhecimento em nível nacional. Sob o impacto dos sentimentos dessa premente renovação, as páginas dos jornais traduziam por seus diferentes colunistas a suposta contribuição da cultura baiana ao cânone artístico brasileiro: "Com grande interesse por parte tanto de artistas como de amadores, foi recebida esta semana a comunicação feita por D. LAVÍNIA MAGALHÃES sobre a criação do Museu de Arte Moderna da Bahia. Desde agora hipotecamos todo o nosso apoio a essa iniciativa, que dará à Bahia mais um elemento de contacto com o resto do mundo, afastando ainda mais aquelas características de isolamento 
provinciano em que se manteve até poucos anos atrás em matéria de arte" ou "Na Bahia estão se realizando coisas de cidade grande; não são as aparentes, ditadas por um urbanismo errado e que vão aumentar os problemas de uma cidade de difícil circulação, mas outras, no campo de imaterial, do espiritual, que, se não é que mais interessa a todo mundo no momento, é, paradoxalmente, o que permanece e fica com ressonância ulterior, na seqüência dos tempos"

Se a missão de renovação das artes - poderiam pressupor muitos intelectuais baianos - era providência dos jovens de Mapa, mesmo que para isso fosse preciso colocar em prática propostas de ataques a um espectro de autores estabelecidos no circuito artístico baiano, nem todas as experiências dos mais velhos foram deixadas em segundo plano.

À época, em fins dos anos 1950, experientes intelectuais e artistas baianos compunham uma lista de nomes de forte influência e por sinal bastante representativos nos jornais, nas revistas e nos círculos e salões baianos. Entre eles estavam: Oswaldo Dias Costa, James Amado, Jorge Amado, João Martins, Hélio Ferrari Vaz, Carlos Vasconcelos Maia, Pedro Moacir Maia, entre outros.

Para o jovem Glauber e seus companheiros estar sob a tutela de alguns deles representava a melhor forma de se inserirem no pequeno circuito artístico baiano. Dessa aliança e convívio, Glauber não se privou e, aos poucos, nele se fez presente. Em 1959, Vasconcelos Maia e Nelson de Araujo organizaram uma antologia, o Panorama do conto baiano. Nela, foram colocados lado a lado autores profissionais e já em circulação entre grandes editoras do país - "muitos deles devotados de maneira integral à sua profissão"” -, como Jorge Amado, James Amado e Adonias Aguiar Filho, com os novatos e de circulação ainda restrita e mais local, caso de Glauber Rocha e João Ubaldo Ribeiro. No texto de apresentação da obra, quando Vasconcelos Maia e Nelson de Araujo expõem seus critérios de seleção, o argumento atravessa exatamente o problema relacional entre a nova e a velha geração:

"Reunindo em suas páginas ficcionistas consagrados e autores apenas iniciantes, ela [a antologia] apresenta, todavia, uma coesão interna que lhe justifica o

\footnotetext{
${ }^{1}$ Lênio Braga, “O M.A.M. da Bahia”, Jornal da Bahia, Salvador (BA), 07-08 jun. 1959, p. 5.

${ }^{2}$ Pedro Moacir Maia, "Jograis na Bahia - I", A Tarde, Salvador (BA), 27 dez. 1956, p. 7.

${ }^{3}$ Vasconcelos Maia e Nelson de Araujo, “Critério”, em Panorama do conto baiano, 1959, p. 10.
} 
aparecimento: a comum influência desta velha cidade do Salvador, que a todos moldou ou afetou com a força do seu espírito [...]

Primeira tentativa desta natureza que se faz na Bahia, Panorama do Conto Baiano, seria de novo essencialmente omisso caso se restringisse aos escritores mais novos, filiados aos movimentos dos últimos lustros, bem definidos com a menção das revistas Caderno da Bahia e Mapa. Pois cumpre notar que, a despeito das diversas orientações que elegeram, as novas gerações baianas têm-se sentido obrigadas a levar em conta o patrimônio cultural que receberam do passado, no que a sua posição coincide com a das outras gerações surgidas desde o Modernismo, divergindo embora em pontos de interpretação e avaliação" ${ }^{4}$.

A constatação dos autores da antologia vinha ao encontro dos interesses de Glauber e seus companheiros. Se, como sugeria a frase-emblema de Mapa, eles pensavam em acomodar, sim, os mais novos, sem, todavia, descartar as tradições dos mais experientes, é de se supor que eles enfrentassem um dilema: o dado provinciano só deixaria de ser a pecha da nova geração, caso pudessem introduzir discussões em sintonia fina com os centros dirigentes nacionais. Isso incluía, entre outras ações estratégicas, inserir o cinema como arte a ser praticada e discutida, missão que Glauber levaria mais a cabo que os demais de sua geração.

Apenas angariar a confiança dos intelectuais locais não era a garantia de sucesso nas instâncias de consagração da produção cultural baiana para esses jovens. Não podiam se furtar de se articular em outros cantos em busca de apoios e apadrinhamentos artísticos. Glauber pensava assim. Tanto é que, em registro epistolar, os propósitos das suas viagens em 1957 por terras mineiras, cariocas e paulistas esboçam uma dessas tentativas. Ele escreve suas impressões sobre as possibilidades dessas alianças e os percalços em angariar fundos para se praticar a arte cinematográfica na Bahia, em carta endereçada do Rio de Janeiro, em 3 de abril de 1957, a Fernando da Rocha Peres e aos colegas de Yemanjá Filmes, a jovem produtora baiana: "Estou escrevendo para ganhar um pouco de ânimo, sou ainda só neste grande Rio de Janeiro apesar de algumas conquistas. Dos grandes daqui uma amizade já foi feita. Alex Viany, um velho com espírito de novo. Tem me assistido [...]” e, em trecho adiante, escreve sobre o apoio que poderia conseguir em outro canto: "Vamos a São Paulo lutar. Se nada foi feito a culpa não foi nossa e também não será de vocês. A culpa será de motivos que caberiam em um ensaio de cem páginas e que possivelmente eu escreverei” ${ }^{2}$.

\footnotetext{
${ }^{4}$ Vasconcelos Maia e Nelson de Araujo, "Critério", em Panorama do conto baiano, 1959, pp. 7 e 9.

${ }^{5}$ Glauber Rocha, Cartas ao mundo, 1997, pp. 89-90 [carta de 03 abr. 1957, Rio de Janeiro (RJ)].
} 
Além de pessoas, havia instituições, também contagiadas pelo clima de mudanças, que apoiavam o grupo de Mapa. Abro aqui o parêntese para o caso da Universidade da Bahia e seu reitor, Edgard Santos. Não é novidade que sua longa gestão pregou e promoveu uma considerável reforma administrativa na ainda incipiente e bastante jovem instituição universitária e para ela levou grandes investimentos nos setores das Humanidades.

Ora visto com bons olhos, ora visto com outros não tão bons olhos assim, é interessante notar a importância que alguns estudiosos têm dado à figura de Edgard Santos no contexto da cultura baiana dos anos 1950 e 1960. Antonio Risério, em seu livro Avantgarde na Bahia, vê Edgard Santos como um "ideólogo modernizante" na capital baiana e que permitiu e, de algum modo, criou as bases para um processo de generalização da cultura erudita. O ensaísta baiano destaca Edgard como uma figura que, longe de ser um homem cultivado, atento e empolgado com as últimas novidades estéticas, é um burocrata habilidoso que cria os mecanismos para que outros pudessem aproveitar a via humanista de uma instituição em clima de mudanças. Para Risério, o que importa mesmo é o reitor ter sido um homem humanista, síntese da seguinte imagem: "Edgard tinha seguramente noção do que lia, ainda que em letras arredondadas por dedos alheios" ${ }^{\text {. }}$. Maria do Socorro Carvalho, no seu livro Imagens de um tempo em movimento, parece partilhar da mesma opinião ou motivações de Risério, já que compreende Edgard Santos “o principal incentivador da Universidade da Bahia”, num "esforço de construção dessa Universidade, tanto material quanto culturalmente" ${ }^{7}$, numa época em que ela atribuiu ser os "anos dourados"

Em outra visão crítica, o protagonismo do reitor é substituído pela análise do tipo de modernização a que ele se ligava e quais interesses estavam em jogo naquele processo histórico. Veja-se a contraposição estabelecida pelo artigo de André Dias, “A universidade e a modernização conservadora na Bahia”, no qual seu autor mostra Edgard Santos não como um herói mítico do progresso e da modernidade, mas, sim, como ator social com toda a herança de um passado ligado à tradicional aristocracia baiana. As mudanças implementadas pelo reitor deixam de ser vistas como modelo para transformações, sejam elas no circuito artístico ou não, mas como um tipo de "modernização conservadora por conta de suas

\footnotetext{
${ }^{6}$ Antonio Risério, Avant-garde na Bahia, 1995, p. 41.

${ }^{7}$ Maria do Socorro Silva Carvalho, Imagens de um tempo em movimento, 1999, pp. 126-127.

${ }^{8}$ Maria do Socorro Silva Carvalho, Imagens de um tempo em movimento, 1999, p. 124.
} 
motivações e interesses profundamente enraizados nos grupos oligárquicos politicamente hegemônicos". Seu argumento está ligado à compreensão de que Edgard, "filho de uma família aristocrática baiana”, foi, na verdade, um legítimo representante das classes dirigentes locais, afinando não um discurso próprio em prol das artes e do desenvolvimento das carreiras universitárias menos utilitárias, mas um discurso pertinente ao jogo político da época. Daí se explica a gestão centralizadora do reitor, num processo sempre marcado pelos jogos de favores e a força trazida pelo dinheiro levantado nos passos de um outro jogo: o de influências em nível federal e órgãos financiadores da época. Segundo André Dias, o reitor levou ao ambiente acadêmico o mesmo modelo de domínio das oligarquias locais, que na disputa de poder na esfera baiana sempre buscavam ocupar os espaços públicos para que pudessem dividir, no momento mais conveniente, os espaços de circulação pelas suas zonas de influência, "segundo as quais as decisões sempre eram tomadas de acordo com os interesses dos chefes e em atenção às reivindicações de seus correligionários" ${ }^{\prime 1}$.

Das duas primeiras abordagens - a de Antonio Risério e de Maria do Socorro Carvalho - não é inadequado supor Edgard Santos como um paladino do desenvolvimento e da onda de modernização baiana dos anos 1950-1960. Elas partem para uma análise de personagens tomados como heróis e constituídos por uma autonomia social. Se isso é discutível? Sem sombra de dúvida. A perspectiva de André Dias, neste sentido, parte de um campo oposto. Em sua análise, consideram-se as relações de poder (e dominação) de Edgard Santos e como isso se tornou possível para o reitor instituir certos pontos de vista dentro do seu espaço social de atuação.

Tendo sob o horizonte essas distintas abordagens, sem, no entanto, basear-se em nenhuma delas, o mais importante, no nosso caso, é pensar como essas mudanças praticadas pelo reitor constituíram uma das bases para a atuação dos mais jovens.

O fato é que ocorreram mudanças dentro e fora dos muros universitários. Implantaram-se novos cursos na instituição, tais como os de dança e de teatro; ampliou-se quase que por consequência do primeiro fator - a rede de relações e de apoio aos intelectuais

\footnotetext{
${ }^{9}$ André Luís Mattedi Dias, “A universidade e a modernização conservadora na Bahia: Edgard Santos, o Instituto de Matemática e Física e a Petrobras”, Revista da SBHC, Rio de Janeiro (RJ), v. 3, n. 2, jul./dez. 2005, p. 126.

${ }^{10}$ André Luís Mattedi Dias, “A universidade e a modernização conservadora na Bahia: Edgard Santos, o Instituto de Matemática e Física e a Petrobras”, Revista da SBHC, Rio de Janeiro (RJ), v. 3, n. 2, jul./dez. 2005, p. 127.
} 
mais jovens. Um apoio não só através do estímulo institucional às artes, mas também material.

Notem-se três registros de repercussão desse suporte financeiro oferecido às camadas de jovens intelectuais baianos da universidade: do próprio Glauber em carta, embora o faça com alguma ressalva: "Por falar em reitorismo, o 'Magnífico' nos conferiu dez mil cruzeiros por trinta exemplares de Samba de roda, o que salvou o prejuízo mas não deu para subornar, como ele pretendeu"11; dos organizadores da revista Ângulos, em finais de 1957, exemplar de que Glauber foi um dos paginadores, ao deixarem o recado em letras garrafais numa de suas últimas páginas da edição número 12: “Ângulos agradece mais uma vez o amparo que lhe foi dado pelo magnífico reitor da Univ. da Bahia Dr. Edgar(sic) Santos" ${ }^{12}$; e dos jovens de Mapa com cordial recado ao reitor, como se nota no editorial da terceira edição da revista: "mapa em terceiro número, graças ao magnífico reitor edgard santos e ao amigo editor pinto de aguiar"13.

Não é de se estranhar que nesse ambiente embebido em clima de renovação e, em alguma medida, com consideráveis recursos também, se importassem professores de todos os cantos e especialidades para a instituição. Pelo ponto de vista dos mais jovens intelectuais da época, a visita desses novos especialistas ao mundo baiano representaria uma boa oxigenação local aos ares ainda apegados ao tradicionalismo estético de pessoas e instituições.

Se não faltaram novos nomes e novas nacionalidades nos quadros institucionais de docência e pesquisa na Universidade da Bahia, a pergunta mais justa passa por saber o alcance desse impulso para o campo da produção artística e crítica de Salvador na época. Quem seriam esses novos professores? Quais seriam suas filiações estéticas e artísticas? Em qual fronteira do espaço social estavam alocados antes da chegada na Bahia? Por fim, e mais importante, eles teriam feito alguma contribuição ou dado algum impulso ao grupo de Mapa?

Para os Seminários Livres de Música, o alemão Hans-Joachim Koellreutter, que estava no Brasil desde os finais dos anos 1930, assumiu, em 1954, a proposta de praticar e pesquisar a música experimental atonal e dodecafônica em circuito baiano. À época, Koellreutter já era artista conhecido em outros centros: estivera à frente de projetos em São Paulo na Sociedade Pró-Arte Moderna e na orientação de jovens, através do grupo Música

\footnotetext{
${ }^{11}$ Glauber Rocha, Cartas ao mundo, 1997, p. 95 [carta de 13 ago. 1957, Salvador (BA), endereçada a Adalmir da Cunha Miranda].

${ }^{12}$ Ângulos, Salvador (BA), ano 7, n. 12, dez. 1957, p. 147.

13 "Editorial", Mapa, Salvador (BA), ano 2, n. 3, ago. 1958.
} 
Viva, por experimentos de música dodecafônica. Além disso, publicou em meados da década de 1940 o "Manifesto 1946”, cuja reação contrária e mais lembrada é a de Camargo Guarnieri em sua polêmica "Carta aberta aos músicos e críticos do Brasil", enviada nos meses finais de 1950, para diversos intelectuais, sendo logo depois publicada no jornal O Estado de São Paulo (17 dez. 1950) e na revista Fundamentos (jan. 1951).

Em outra área, a polonesa Yanka Rudzka viera para compor o quadro docente para os experimentos em dança na universidade. Convidada pelo próprio Koellreutter, e sem ser ainda institucionalizada pela universidade, Yanka ministra cursos livres, em 1954, e apenas, em 1956, chega definitivamente às terras baianas, para, em seguida, constituir as bases para a implantação do que seria no futuro a Escola de Dança. O caso de Yanka, tal como o de Koellreutter, inclui um período inicial de trabalho em terras paulistas. Ela chegou ao Brasil por conta do convite de Pietro Maria Bardi, o marido de Lina Bo Bardi, para o trabalho junto ao Museu de Arte de São Paulo (Masp), para, na sequência, desenvolver outras atividades sempre com o ensino experimental de dança e coreografia.

Como se pode notar, já havia entre parte dos professores estrangeiros que chegam à Bahia para a formação dos quadros docentes em artes uma relação iniciada momentos antes na capital paulista. O depoimento de uma das alunas de Yanka, Yolanda Amadei, dá evidências, por exemplo, da ligação entre Rudzka e o músico alemão: “A Yanka também dava aulas na Pró-Arte dirigida pelo Koellreutter, associação ligada principalmente à música, com sede na rua Sergipe. Quando o projeto dela no MASP não deu certo, fomos para a Pró-Arte, onde estudei bastante tempo com ela - o que foi muito bom porque estávamos próximos ao Koellreutter, um grande maestro que nos dava algumas aulas"14.

Para as atividades de teatro na universidade, a vaga seria assumida por Martim Gonçalves, que fundaria a Escola de Teatro, uma das primeiras do país. O cenógrafo e diretor vinha com a experiência de ter trabalhado na companhia Os Comediantes com o polonês Zbigniew Ziembinski na montagem de 1946, de O desejo, de Eugene O’Neill. Martim havia também trabalhado em produções, no Rio de Janeiro, do Teatro de Marionetes. Mesmo que não fosse um praticante do teatro experimental, por assim dizer um "vanguardista" - tal como eram vistos Koellreutter e Rudzka -, Martim conseguiu boa repercussão do seu trabalho na capital baiana. Fixou-se muito mais nas montagens de peças consagradas e trouxe para terras baianas pela primeira vez encenações do teatro brechtiano, caso da Ópera dos três

\footnotetext{
${ }^{14}$ Yolanda Amadei, Memória da Dança em São Paulo, 2007, p. 39.
} 
vinténs. Ligado a Martim, no que diz respeito ao preparo cênico, havia as contribuições da arquiteta italiana Lina Bo Bardi, que já estivera antes na universidade para o ensino de Arquitetura, na Escola de Belas Artes, e que naquele momento estava em Salvador, a convite do então governador Juracy Magalhães, para a criação do Museu de Arte Moderna da Bahia, o primeiro do gênero na época.

As transformações no quadro docente não param por aí.

Para a fundação do Centro de Estudos Afro-Orientais (CEAO), uma novidade naqueles tempos, o reitor Edgard Santos trouxe o português Agostinho da Silva, compondo, assim, o corpo estrangeiro da universidade. O intelectual português, talvez o mais experiente de todos esses professores de fora, acumulava uma vivência singular. Ele chegara ao Brasil depois de ter cursado Filologia Clássica, na Universidade do Porto, e depois de ter defendido o seu doutorado com a tese "O Sentido Histórico das Civilizações Clássicas". Sem contar suas colaborações que já havia feito para a importante revista Seara Nova, de Portugal.

No momento em que Agostinho da Silva chega à Bahia, ele já tinha percorrido várias regiões na América do Sul e divulgado seu trabalho em diferentes universidades brasileiras (Rio de Janeiro, Paraíba, Santa Catarina, Pernambuco, entre outras). Em alguns casos, como o da Universidade de Santa Catarina, ele havia sido um dos mentores para a fundação da própria instituição. Somado a tudo isso, em parceria com o não menos importante historiador português Jaime Cortesão, Agostinho foi um dos organizadores da “Exposição do Quarto Centenário”, em São Paulo, no ano de 1954.

Deste espectro de professores que chegaram à Bahia, exceção feita a Martim Gonçalves, que era brasileiro, embora com período de formação na Inglaterra no Ruskin College Oxford por conta de uma bolsa de estudo, os demais eram europeus e encontravam no Brasil o refúgio para a prática artística sem as perseguições e variáveis de uma inconveniente situação própria dos períodos anteriores e posteriores à Segunda Guerra. Este, no entanto, não é o dado mais importante e a chave de leitura para se compreender suas respectivas inserções no ambiente artístico da Bahia a ponto de iluminar as possíveis (e prováveis) relações desses fatos e fatores com as práticas artísticas implementadas pelos jovens de Mapa.

Fechado o longo parêntese sobre a instituição universitária baiana e suas modificações lançadas na realidade local, é momento de se analisar como essas mudanças, tanto com a chegada dos novos professores como com a constituição de cursos menos 
utilitários, podem ter atingido Glauber e seus companheiros de Mapa. As terras baianas se impunham para aqueles estrangeiros como nova etapa de vivência no Brasil. Se já estavam profundamente marcados pelas experiências do trabalho tanto no Rio de Janeiro como em São Paulo, constituindo, muitos deles, grupos de interlocução sólidos, o trabalho em Salvador trazia novas perspectivas: tinham à disposição uma estrutura institucional e o apoio financeiro, senão exclusivo, com uma boa oferta de dinheiro. Mesmo que tivesse representado uma mostra do poder do reitor e que, por esse horizonte, fosse parte de sua estratégia e a de uma elite dirigente baiana para a constituição de um modo de modernização conservadora, a chegada desses novos professores, sem dúvida, criou uma outra dinâmica na vida cultural baiana e por esta nova configuração seus jovens, incluindo o grupo de Mapa, receberam outros modelos de formação intelectual. Pode-se supor, entre outras coisas, que, naquele momento, configurava-se um quadro como este:

1) sob a tutela dos docentes estrangeiros, aqueles novos experimentos artísticos, tidos como arte de vanguarda, mais o pensamento desenvolvimentista, em parte demarcado pela poesia concreta de então e pela mitificação em torno da construção de Brasília, trouxeram um novo modelo de prática intelectual e artística para aqueles jovens baianos. Estavam, todos eles, marcados por um hibridismo entre o veio local e outro cosmopolita. Não é à toa que Glauber, em 1959, filma um curta-metragem, Pátio, em claro diálogo com as pregações concretas vindas principalmente do Rio de Janeiro e, ao mesmo tempo, escreve o conto "Retreta na praça"15, de um realismo das terras baianas, quase colado ao estilo de um jovem Jorge Amado - talvez a mesma "realidade honesta" de que Mário de Andrade falou na ocasião da leitura de Mar morto, em 1936;

2) abria-se uma perspectiva a um novo tipo de formação, em termos humanísticos, aos mais jovens. Com a chegada daqueles docentes e uma série de colaboradores - estes sempre em visita à cidade baiana -, aumentou-se o número de espetáculos, fossem eles de teatro, música ou dança, o que só fazia crescer a movimentação e o burburinho com respeito às modificações daquele mundo cultural. Basta uma boa passada de olhos pelos jornais da época para notar a dimensão de tal situação;

3) os jovens, certamente apreendidos por aqueles novos valores e, de algum modo, estimulados por tudo aquilo, puderam constituir um novo esquema de difusão para seus pensamentos, embora também mantivessem a utilização das formas mais tradicionais,

\footnotetext{
${ }^{15}$ Cf. Glauber Rocha, “Retreta na praça”, em Panorama do conto baiano, 1959, pp. 81-86.
} 
como a dos grandes jornais de Salvador. De todo modo, com o apoio institucional de parte da comunidade intelectual e artística e, de certa forma, da própria Universidade da Bahia, eles buscaram, através desses novos esquemas de difusão, a demarcação de sua geração por alguns feitos, sempre no contraste em relação aos seus predecessores. Formulava-se, por assim dizer, um problema geracional entre eles;

4) Não abordado, salvo engano, de forma suficiente pela crítica especializada da Sociologia e da Antropologia, a questão é que, com a constituição do CEAO e os trabalhos de Agostinho da Silva, surgia uma maior valorização dos elementos da cultura afro-baiana, que aos poucos, como ideia de arte popular, foram incorporados ao campo de produção erudita, constituindo uma nova opção em termos de tradição para aqueles jovens intelectuais baianos.

Foi com esta Salvador que os jovens de Mapa se depararam: a favor tinham uma promissora movimentação e, em contraposição, toda uma estrutura social que se modificaria muito lentamente, ainda arrastada pelo pensamento da oligarquia local. Diante disso, não havia alternativas. Precisavam agir e criar estratégias de se inserirem e de divulgarem seus trabalhos no circuito intelectual local. Entre os seus feitos que representaram marcos, dois se destacaram: a feitura da revista Mapa - origem do nome do grupo - e as teatralizações de poemas, que ficaram conhecidas como As Jogralescas. Estas últimas, o motivo dos comentários seguintes.

As teatralizações ainda se iniciam nos tempos de colégio.

Em 1954, Glauber Rocha começou o curso clássico no Colégio Central em Salvador, instituição estadual bastante conhecida na cidade. Pouco tempo depois, tornou-se membro do Círculo de Estudo, Pensamento e Ação (CEPA), cuja direção era do professor Germano Machado, homem tido como católico, nacionalista e anticomunista pelo olhar local. Mais do que um centro irradiador de ideias e caminhos para o jovem Glauber e seus companheiros que ainda se formavam em termos intelectuais, este Círculo conseguiu constituir um sólido grupo de interlocuções sobre o mundo cultural baiano. Independente das sessões formais comandadas pelo professor Machado, segundo o relato de João Carlos Teixeira Gomes, um dos seus participantes, esses jovens se reuniam diariamente para escrever e ler contos e poemas na porta da Livraria Civilização ou na Biblioteca Pública de Salvador ${ }^{16}$.

Num destes encontros, já em 1955, Glauber e um de seus amigos, Fernando Péres, tiveram a ideia de teatralizar poemas, estabelecendo aquilo que ficou conhecido como

\footnotetext{
${ }^{16}$ Cf. João Carlos Teixeira Gomes, Glauber Rocha, esse vulcão, 1997, pp. 27-85.
} 
As Jogralescas. Não tardou que o grupo conseguisse tanto o reconhecimento e destaque no cenário cultural baiano e, em alguma medida, fora dele. Críticas e notícias foram estampadas em diversos periódicos sobre suas encenações.

A ideia das teatralizações, segundo o próprio Glauber, em depoimento ${ }^{17}$ nos anos 1970, partiu de encenações de poemas brasileiros de qualidade e dotados de sentido nacionalista, em oposição a uma declamação de molde mais clássico. Numa explicação dada ao fenômeno d'As Jogralescas, que pode ser lida na revista Mapa número 2, seus organizadores disseram que o movimento surgiu como uma medida de aproximação da poesia e do povo, com o poema sofrendo o tratamento teatral e submetido a uma mise-enscène e a uma cenografia. Seu público receberia, assim, "com agrado para os olhos e para os ouvidos, toda uma antologia poética que cumpre, ao mesmo tempo, uma finalidade pedagógica e estética"18.

Por certo, o grupo sabia das restrições inerentes ao se dramatizar um poema. A resposta desses jovens vinha, no sentido, de responder àqueles que, por ventura, achassem que só a leitura silenciosa ou a leitura de uma ou mais vozes emitidas por pessoas estáticas poderia transmitir o máximo da intensidade lírica ou dramática de um poema. Toda opinião deles reforçava o valor das encenações e eles, assim, diriam que "sob outro aspecto podemos chegar que a 'teatralização' de poemas possuidores de vivas sugestões plásticas e de rica movimentação, traz e confere a estes uma dignidade artística e superior àquela em exclusivo estado de palavra. E ainda surge um esforço insofismável - e aqui experimentamos e provamos -: o público recebe o poema encenado com mais 'simpatia' do que o poema 'declamado'”'

Em meados de 1957, em sua quarta apresentação, o grupo sofreria manifestações contrárias a sua continuidade. Conforme um memorial do jornal $A$ Tarde, de Salvador, a 3 de julho daquele mesmo ano, cujos signatários eram a professora Dalva Matos e seus diversos seguidores - entre eles os professores Cícero Bahia Pedreira Ferraz, José Maria da Costa Vargens, Raimundo Pereira - , revelava-se que o protesto se baseava numa suposta falta de respeito do grupo aos motivos religiosos católicos. Em um dos seus primeiros parágrafos, o texto já explicita a ideia que seus signatários tinham sobre aqueles jovens:

\footnotetext{
${ }^{17}$ Cf. Glauber Rocha, "Glauber Rocha: eu e o cinema (fotogramas de uma vida)”, Versus, n. 6, out./nov. 1976, pp. $15-18$.

18 “A jogralesca. Explicação”, Mapa, Salvador (BA), ano 1, n. 2, 1957, pp. 81-82.

19 “A jogralesca. Explicação”, Mapa, Salvador (BA), ano 1, n. 2, 1957, pp. 81-82.
} 
"O que temos, em nossa terra, são jovens mal orientados que, à falta da necessária assistência dos pais, se deixam influenciar pelo cinema, o rádio, a literatura de quadrinho, qualquer coisa que lhes fale à exaltada imaginação.

Por isto mesmo, trabalhadas pelas idéias materialistas que dominam o mundo moderno, desprezam tradições, enfrentam preconceitos e vão até o ponto de escarnecer os sentimentos religiosos daqueles que continuam fiéis às suas crenças" ${ }^{20}$.

Para os dias de hoje, é curioso notar a que ponto aquelas encenações de jovens, diga-se de passagem com nem 20 anos completos, repercutiam entre os conservadores locais. Segundo eles, os rapazes eram uma verdadeira ameaça à "herança moral da Pátria” e aos bons costumes. O protesto em relação aos jovens por si só já é um fator a ser levado em conta para se ter a ideia da dimensão das interferências na atmosfera cultural baiana de então. Dois fatos dentro das teatralizações chamaram a atenção dos que protestavam, que aqui merecem ser transcritos pelo tom peremptório, que beira à tolice, de suas interpretações:

\begin{abstract}
"Num dos intervalos, teria sido apresentado no palco um cartaz com os dizeres: 'Amados Irmãos: Entenderam? Se entenderam por que ainda não gemeram? Amém. - Imprimatur. Nihil Obstat', enquanto que pessoas travestidas de sacristães do culto católico apresentavam, pilhericamente, sacolas solicitando óbulos (sic) à platéia. Já do programa constava poesia 'Blasfêmia', cujo sentido, evidentemente mal inspirado, se presta a desfazer da religião

Ora, aqui há poucos dias, celebramos a Páscoa dos Estudantes, precedida de palestras religiosas. Como silenciar, quando alguns poucos elementos, - talvez na irreflexão de uma infeliz brincadeira, apenas, - procuram deslustrar a Religião Católica numa ostensiva deselegância para com a maioria dos que vieram, convidados, ao auditório?"21.
\end{abstract}

Como se percebe, a forma condicional do "teria sido" só diz contra eles mesmos. Sugere que os signatários protestaram sem, de fato, terem ouvido ou visto as apresentações. Ou seja, protestaram por ouvir dizer. E não porque tenham acompanhado as encenações dos rapazes. É de se ainda supor que um dos trechos do longo poema "Blasfêmia", de Cecília

\footnotetext{
${ }^{20}$ Dalva Matos e al, "Memorial da Congregação do ginásio da Bahia à direção do estabelecimento", A Tarde, Salvador (BA), 03 jul. 1957, p. 5.

${ }^{21}$ Dalva Matos e al, "Memorial da Congregação do ginásio da Bahia à direção do estabelecimento", $A$ Tarde, Salvador (BA), 03 jul. 1957, p. 5.
} 
Meireles, que chamou a atenção da ala católica baiana tenha sido as duas estrofes, a antepenúltima e a penúltima:

\author{
"Ah, santa insensível, \\ não sofres, não pecas! \\ Senhora da Várzea! \\ Senhora da Serra! \\ Devolve o ouro e a prata \\ das minhas ofertas! \\ Que o vento arrebente \\ portas e janelas \\ das tuas igrejas! \\ E fiquem nas trevas \\ ou sejam levados \\ pelas labaredas \\ altares queimados \\ e naves desertas! \\ Caiam no teu peito \\ mais agudas setas! \\ Arda em brasa o ramo \\ que nas mãos carregas! \\ Nunca mais se arrastem \\ meus joelhos nas pedras, \\ nem a minha boca \\ suspire mais rezas! \\ Nunca mais andores, \\ nem círios nem festas! \\ Dei-te seis igrejas: \\ que me deste? Lepra!" 22.
}

Talvez por ignorância dos fatos ou por simples moralismo, os versos de Cecília Meireles incomodaram, e muito, o grupo de Dalva Matos. A reação, no entanto, foi revertida de outro modo nas páginas dos jornais.

Após a publicação da referida moção, vários intelectuais, artistas e jornalistas vieram a público em defesa dos jovens d'As Jogralescas. A ressonância do acontecido pôde

\footnotetext{
${ }^{22}$ Cecília Meireles, "Blasfêmia”, Mar Absoluto e outros poemas, em Obra Poética, 1967, p. 305.
} 
ainda ser sentida fora do próprio estado baiano, como foi o caso de São Paulo: graças à presença do crítico Adalmir da Cunha Miranda, autor da coluna semanal "Crônica de Salvador" n'O Estado de S. Paulo, As Jogralescas tiveram a cobertura da imprensa paulista. $\mathrm{Na}$ ocasião dos protestos da quarta encenação, este mesmo crítico, bem informado pelo diálogo epistolar mantido com o jovem Glauber, conseguiu reunir um grupo variado de intelectuais e artistas da cena paulista para uma manifestação de apoio aos jovens baianos, que foi lida na quinta e derradeira encenação. Datada de setembro de 1957, esta moção apresentada pela Sociedade Paulista de Escritores, pela Associação Brasileira de Escritores e pelo Clube de Poesia do Brasil - foi assinada por nomes como Renata Pallotini, Paulo Dantas, Sábato Magaldi, Décio de Almeida Prado, Lourival Gomes Machado, Lygia Fagundes Telles, Ricardo Ramos, entre muitos outros. Reproduzida na edição número 2 de Mapa, o referido documento apontou que seus signatários estavam cientes dos acontecimentos de Salvador pela cobertura dos jornais $A$ Tarde e $O$ Estado de S. Paulo. A moção focalizou a valorização dos espetáculos d'As Jogralescas, segundo eles, uma iniciativa de "moços da Bahia” com "alto valor estético", em que se destacavam uma seleção de poemas de autores representativos de "um patrimônio cultural do país". Todos os signatários diziam estar certos da seriedade da investida daqueles moços, porque se tratava de "tarefa tão admirável de dignificação e difusão da cultura literária”. Nada mais justo, portanto, para os signatários, que aquela moção trouxesse um gesto político: o de solicitar o apoio das autoridades locais baianas para o grupo e o de expressar "o seu aplauso às "Jogralescas"” e a sua discordância "contra pessoas e grupos obscurantistas que não representam, em hipótese alguma, a reconhecida e autêntica inteligência bahiana $(\ldots)^{m 23}$.

Ressalte-se que o círculo de opiniões ampliou-se ainda mais, conforme se vê nas páginas do referido exemplar da revista Mapa, de 1957. Neste mesmo periódico ainda estampou-se um texto crítico do linguista português da Universidade de Coimbra, Armando de Lacerda. À época, de passagem pela cidade baiana, o professor português pôde acompanhar a quarta e famosa apresentação d'As Jogralescas. Ficara admirado com o grupo, pois, segundo suas palavras, tratava-se de "gente muito nova, que, apesar de sua pouca idade, conseguiu revelar extraordinárias possibilidades artísticas” ${ }^{24}$, chegando a afirmar que a apresentação fora "uma bela afirmação da gente moça, uma grande lição para todos aqueles

\footnotetext{
${ }^{23}$ Vários autores, “Escritores paulistas saúdam a Jogralesca”, Mapa, Salvador (BA), ano 1, n. 2, 1957, p. 89.

${ }^{24}$ Armando de Lacerda, “Depoimentos”, Mapa, Salvador (BA), ano 1, n. 2, 1957, p. 87.
} 
professores de literatura que, em vez de estarem presentes, com o seu saber e experiência à disposição dos novos, se alheiam, incompreensivelmente, do mundo de realizações poéticas que mais vivamente pode ser sentido pela nova geração, pelos homens de amanhã ${ }^{25}$. Ainda neste mesmo exemplar de Mapa foram incluídas as reproduções das opiniões de Carvalho Filho, o poeta baiano, e de Hernani Cidade, outro catedrático, de Literatura Portuguesa da Universidade de Lisboa, em Portugal.

Em termos locais, Pedro Moacir Maia foi um dos maiores entusiastas do grupo. Consagrou-o em dois artigos publicados sob o título de "Jograis na Bahia", I e II, no jornal $A$ Tarde. Em seu primeiro texto, de 27 de dezembro de 1956, tendo em vista a terceira jogralesca, ele fez questão de imprimir uma fisionomia ao grupo: eles não praticavam um tipo de recitação cujo ponto alto seria a voz embargada, demonstração de "uma subliteratura melosa, sentimentalesca"26, mas, sim, uma reação a esse modelo, numa prática que já pudesse envolver tanto os "grandes azes de nossa literatura contemporânea" ${ }^{27}$ como a encenação com substanciais caracterizações cênicas e gesticulações próprias do teatro, num todo que explorava a plena teatralidade do poema. Segundo ele, era uma forma original daqueles jovens acrescentarem novos dispositivos às leituras de poemas, e, assim, ultrapassar as formas dos recitais clássicos, cuja limitação estava na subordinação quase exclusiva à voz do declamador.

O mesmo tom elogioso continua em seu segundo texto, publicado a 3 de janeiro de 1957. Diferente, porém, do primeiro texto, Pedro Maia oferece uma especificidade maior de análise e aponta nos principais poemas o modo como aqueles jovens se sobressaíam. Vejase, por exemplo, seus comentários sobre “Essa nega Fulô!”, de Jorge de Lima, em que o crítico notabiliza não a força da "emoção" que o poema por uma tradicional desenvoltura declamatória poderia trazer e, sim, uma nova prática configurada pela "sábia modalidade de humor ou ironia, modulações de voz e variações dos mesmos gestos, tudo usado com infinita graça pela garota a nos contar o acontecido e que parecia estar também se divertindo com aquilo, não houvesse no poeta, em sua intérprete, e em nós todos, um pouco de malícia"28. Dois trechos sintetizam muito bem o grau de aderência do crítico às ideias do grupo: "quem lendo essas linhas achar muitos os adjetivos, vá assistir ao próximo recital dos jograis, e dirá,

\footnotetext{
${ }^{25}$ Armando de Lacerda, "Depoimentos", Mapa, Salvador (BA), ano 1, n. 2, 1957, p. 88.

${ }^{26}$ Pedro Moacir Maia, "Jograis na Bahia - I”, A Tarde, Salvador (BA), 27 dez. 1956, p. 7.

${ }^{27}$ Pedro Moacir Maia, “Jograis na Bahia - I”, A Tarde, Salvador (BA), 27 dez. 1956, p. 7.

${ }^{28}$ Pedro Moacir Maia, “Jograis na Bahia - II”, A Tarde, Salvador (BA), 03 jan. 1957, p. 11.
} 
como dissemos, que sucesso!"29, e mais adiante, "deixemo-los fazer o que querem e como querem - um grupo que organiza um espetáculo desses é excepcional. Que choquem nossa moralidade e nosso pretenso bom gosto!"30.

Todas essas reações constituem marcas de opinião de grupos consagrados nacionais, daqueles de apoio local e de grupos contrários e representam em si uma vitória dos jovens de Mapa. Para eles, o objetivo em termos de repercussão e inserção do grupo no debate cultural havia sido realizado com sucesso a partir d'As Jogralescas. Porque parcelas de intelectuais, ligados por motivos dos mais distintos possíveis, tiveram dois tipos de reação: seja de reconhecimento, seja de discordância e recusa. Glauber e seus companheiros, por meio das teatralizações conseguiram, mesmo que por um momento, polarizar as forças locais, jogando frente a frente os defensores de uma cultura mais tradicional e de base católica contra os defensores de um modernismo estético, do qual esses jovens eram uma das partes mais interessadas.

Foi visto até o momento que As Jogralescas representaram um marco para que o grupo se tornasse mais conhecido. Não foi o único. A este ligou-se a própria organização da revista Mapa e, em outro grau, a editora Macunaíma. Fixarei os comentários na primeira.

Com a publicação apoiada pela Associação Baiana de Estudantes Secundários (ABES), a organização da revista estava vinculada a uma direção editorial, ora na mão de Fernando da Rocha Peres, ora na mão de Glauber, e a uma orientação gráfica, que obteve importante contribuição de Calasans Neto. Como se pode notar pelos expedientes e sumários do periódico, dele ainda participaram muitos nomes que depois despontariam no cenário de produção crítica e artística baiana, a destacar: Albérico Motta, João Carlos Teixeira Gomes, Florisvado Mattos, Paulo Gil Soares, Carlos Anísio Melhor, Silva Dutra, Sante Scaldaferri, Frederico José de Souza Castro, entre os demais. Tudo isso sem contar as colaborações externas de outros estados e ainda os veteranos locais que se mesclavam aos mais jovens, casos do crítico de arte Wilson Rocha, do cineasta e crítico Alex Viany ou do pintor Di Cavalcanti.

Aos olhos de hoje, é possível dizer que Mapa - não mais encontrável em sebos, mesmo os melhores, e raridade em bibliotecas do país - pode ser considerada uma revista cultural de variedades, pois nela se estamparam trabalhos de organizadores e colaboradores

\footnotetext{
${ }^{29}$ Pedro Moacir Maia, “Jograis na Bahia - II”, A Tarde, Salvador (BA), 03 jan. 1957, p. 11.

${ }^{30}$ Pedro Moacir Maia, “Jograis na Bahia - II”, A Tarde, Salvador (BA), 03 jan. 1957, p. 11.
} 
em torno de variados gêneros: ensaio, contos, poemas e crônicas, tudo isso numa edição com cuidadoso valor gráfico. Para se ter uma ideia deste esmero visual, em cada um dos seus três números acrescentou-se um encarte especial com a reprodução de obras de artistas plásticos locais.

Além de refletir o espírito desses jovens, essa variedade de Mapa também representa certa ambição intelectual por um público mais heterogêneo, menos especialista talvez. Trata-se ainda de fazer frente, embora de forma marota, porém pensada, à fração dominante de intelectuais estabelecidos. Vistos em conjunto, o aparecimento da revista, mais as teatralizações n'As Jogralescas, encaixavam-se nessa linha estratégica. Cabe como registro desse propósito, o primeiro texto editorial da revista: “[...] Queremos as gerações passando por estas páginas, queremos falar do presente como é, e do futuro quando chegar. Ambos, presente e futuro, devem entregar tudo de si através do pensamento moço. O jovem tem um destino, tem uma bandeira não para carregar em desfile patriótico, e sim para abrir ao vento e ficar alerta [...] Mapa é uma afirmação do que somos. Mocidade voltada para problemas de arte e que não deixa de conhecer os problemas do Brasil”31.

Como número de estréia da revista, Mapa precisava ser apresentada por alguém já conhecido em Salvador. Se possível por um artista de amplo reconhecimento entre os vários estratos intelectuais da cidade. Não pensaram duas vezes em dispor de um nome representativo para setores tradicionais da cultura baiana. Foi desse modo que Carvalho Filho, um dos participantes da onda modernista baiana em finais dos anos 1920 e um dos organizadores de Arco e Flexa, foi convidado a apresentar os moços de Mapa. Com um texto estampado nas primeiras páginas do primeiro número do periódico, Carvalho Filho não poupou elogios sobre o projeto de atuação daqueles jovens, que para ele, por mais paradoxal que possa parecer hoje, estavam criando o próprio espaço de ação sem a necessidade de se vincular a qualquer pessoa ou grupo de estabelecidos: "Esses moços não desejam naufragar no mar de fezes que nos assoberba. Querem salvar por conta própria, sem tutela de medalhões, uma voz que já ouviram no fundo da alma e que, sem o seu heroísmo pessoal, perecerá no limbo. Pretendem, por isso, criar o espaço e o seu destino, pois não há a quem invocar proteção"32.

\footnotetext{
${ }^{31}$ Mapa, Salvador (BA), ano 1, n. 1, 1957, s/p [encontra-se na contracapa da revista].

${ }^{32}$ Mapa, Salvador (BA), ano 1, n. 1, 1957, p. 1.
} 
Com curtíssima duração, a revista, do início ao fim, não deixou de alinhar um mesmo discurso de atuação. Seu último editorial, de Mapa número 3, que, segundo informa João Carlos Teixeira Gomes, fora escrito pelo próprio Glauber ${ }^{33}$, é bastante representativo dessa definição. Escrito por Glauber ou não, parece ser mais importante sua perspectiva de síntese tanto em relação à atuação de Mapa como veículo de difusão de ideias em Salvador, funcionando, para usar um termo comum aos dias de hoje, como grupo de pressão junto às autoridades e aos dirigentes do circuito artístico baiano, como em relação às linhas de força a que o grupo estava sujeito, precisando combater e defender pessoas e pensamentos distintos. Para a abordagem de seus temas e questões, este editorial pode ser divido em três partes:

A primeira delas representou uma síntese sobre o papel de Mapa como veículo de repercussão entre uma juventude que se diz atenta, preocupada e com ideias próprias diante dos problemas culturais da terra, daí se justificar a necessidade de uma posição, segundo eles, fundamental: "editar os novos sobretudo, os mais velhos na medida do possível e do justo" ${ }^{34}$, a frase-síntese que já considerei apropriada para se pensar a plataforma dessa nova geração. Só assim, dentro dessa "angulação bem enquadrada" ${ }^{35}$, seria possível ficar de olhos abertos sobre uma prática de retrocesso cultural na Bahia, lugar que, segundo eles, representava uma "casa por excelência da tradição e do culto ao passado e da robusta mitologia em torno de falsos valores daqui e de outras terras" ${ }^{\prime 36}$. Nesta primeira parte, o editorial firmava a voz institucional de Mapa e o que eles estabeleciam como base de um ideário de grupo, ou seja, aquilo que estavam reafirmando no debate baiano desde as primeiras apresentações de $A s$ Jogralescas até o que foi referenciado nos números anteriores da revista.

A segunda parte do editorial demonstrou a posição de grupo em referência às lutas políticas e aos jogos de poder que limitavam a atuação deles frente às camadas (não aliadas, diga-se bem) que dominavam e ocupavam as várias estruturas da prática cultural baiana. Sem meias palavras, o grupo logo se dirigiu ao governador do estado, que à época se incumbia da reconstrução das dependências do Teatro Castro Alves, danificadas por um incêndio. E, quase em tom de denúncia, voltavam seus ataques em direção à comissão de cultura artística do estado, responsável também pela direção desse mesmo teatro, dizendo ser os seus membros, salvo três ou quatro exceções, representantes da reação e da ignorância

\footnotetext{
${ }^{33}$ Cf. João Carlos Teixeira Gomes, Glauber Rocha, esse vulcão, 1997, p. 37.

34 “Editorial”, Мapa, Salvador (BA), ano 2, n. 3, ago. 1958, sem paginação.

35 "Editorial”, Mapa, Salvador (BA), ano 2, n. 3, ago. 1958, sem paginação.

36 “Editorial”, Mapa, Salvador (BA), ano 2, n. 3, ago. 1958, sem paginação.
} 
"mistificada da Bahia", o "sangue velho em farra pseudo-artística" ${ }^{37}$. A defesa de alguma forma trançava aquilo que foi divulgado no plano de ação de As Jogralescas, a ideia de se pensar a prática artística aproximada do povo com a própria razão de existência divulgada no primeiro exemplar da revista, ou seja, moços que querem "falar do presente como é, e do futuro quando chegar" ${ }^{\text {"3 }}$. Daí suas cobranças às autoridades: "se o teatro é do povo como a política anuncia, que o primeiro espetáculo seja para o povo e não para a burrice de casaca" ${ }^{39}$. Segundo eles, a necessidade de mudanças é inevitável, caso contrário, as consequências poderiam ter seus efeitos além do localismo baiano; é curioso notar o argumento arrolado pelo grupo: "sr. Governador, cumpre também evitar que a Bahia se desmoralize no Sul" ${ }^{4}$.

Por fim, a terceira parte inicia em tom de aviso. Reafirma a missão de seus jovens para em seguida comunicar a brevidade de Mapa, que por falta de recursos poderia deixar de circular. O tom de aviso, no entanto, dá lugar ao revide cheio de protesto: "uma publicação cultural é sempre estrangulada quando abala os ídolos moles”. Estava dado em linhas gerais o pesado recado. Bastava esperar as repercussões das circulações das ideias.

O fim de Mapa não representou o fim do grupo, nem tampouco o fim da atuação de Glauber, como se sabe. Em regras gerais, o grupo de Mapa fez-se perceber dentro desse cenário de mudanças soteropolitanas. Além de ganharem espaço nos jornais com a divulgação de suas ações, a visibilidade social dessa repercussão abriu novas perspectivas de atuação aos participantes do grupo. Representou a oportunidade de enfrentarem uma redação e adquirirem o primeiro posto de trabalho profissional no jornalismo: foi assim com Glauber, como veremos adiante; foi assim com João Carlos; foi assim com tantos outros do grupo.

A revista serviu de teste para a vida intelectual adulta, já que boa parte dos integrantes pôde incorrer na prática escrita do ensaio, da prosa de ficção, da crônica ou mesmo da poesia. Mesmo antes dos 20 anos de idade, muitos deles puderam promover seus primeiros debates públicos em torno de políticas culturais e discutir os possíveis rumos de uma produção artística e intelectual contemporânea, o que não representava pouco para moços recém-chegados à vida adulta.

\footnotetext{
37 "Editorial", Mapa, Salvador (BA), ano 2, n. 3, ago. 1958, sem paginação.

${ }^{38}$ Mapa, Salvador (BA), ano 1, n. 1, 1957, sem paginação [encontra-se na contracapa da revista].

39 "Editorial", Mapa, ano 2, n. 3, ago. 1958, sem paginação.

40 "Editorial", Mapa, ano 2, n. 3, ago. 1958, sem paginação.
} 
De modo específico, com a revista Mapa, formalizava-se um espaço de difusão para o pensamento do jovem Glauber Rocha. Sem demora, ele notou as possibilidades que o novo veículo trazia e tratou logo de experimentar a divulgação de ideias que condensassem sua via mais nacionalista na valorização de escritores do romance social e na valorização de formas artísticas como modelos de defesa de uma cultura local. Questões, estas, de interesse a seguir.

\section{Explicação para José Lins do Rego}

Em 1957, na revista Mapa número 2, Glauber Rocha publicou aquilo que, salvo engano, foi o seu primeiro ensaio de fôlego sobre um autor da literatura brasileira. Utilizando ainda seu sobrenome Andrade, ele dedicou quase 20 páginas ao escritor José Lins do Rego, que havia falecido naquele mesmo ano. Embora possa ser encarado como uma homenagem póstuma, a leitura desse texto sugere a necessidade de apreensão de outros propósitos seus. Um exame mais detalhado se dá não só pela compreensão dos impactos que um romancista de forte ligação com o regionalismo nordestino pode ter ocasionado em um jovem baiano ainda em formação, mas também pela busca e compreensão da visão nacionalista e de arte moderna explicitada pelo jovem crítico - por certo, esta, tributária também das leituras do autor de Fogo Morto, um escritor que Glauber considerava o grande romancista moderno brasileiro, por excelência.

O ensaio "Romance de José Lins do Rêgo" é dividido em cinco partes: uma explicação inicial, uma visão geral sobre os romances, um exame sobre o ciclo de cana-deaçúcar, uma análise dos últimos trabalhos de José Lins e uma pequena conclusão.

Já no preâmbulo do artigo, quando se implementa uma explicação inicial com os propósitos da abordagem, Glauber, bem ao estilo modernista, passou os recados. Não se conteve e foi incisivo. Deu nome aos bois e guiou-se por uma visão nacionalista de defesa da nossa literatura e das coisas da nossa terra. Estava compelido a fazer incutir nos jovens tais valores. Missão quase compulsória, o crítico de Mapa precisava deixar claro a todos que a abordagem não se devia à morte do escritor, mas que todas aquelas ideias vinham de percurso de longa data. Por trás disso, Glauber reafirmava a necessidade de valorização de seus escritores preferidos, com destaque para José Lins, para, assim, fazê-lo penetrar em lugares 
fechados dentro das discussões culturais baianas, ou como dizia, em lugar "imbecilmente fechado para ele" ${ }^{31}$.

Glauber supõe que a desvalorização de José Lins por setores jovens da sociedade baiana - e é isto que ele notava naquele momento - ligava-se irremediavelmente às inúmeras interferências vindas de fora, em parte pela propagação de teorias e modismos que gravitavam em torno do gosto de jovens fascinados, e pela pregação de certos autores de literatura fácil, cujo exemplo salientado é o de Campos de Carvalho, autor de Uma lua vem da Ásia. Sua disposição está em falar para um grupo mais amplo de jovens, principalmente aqueles que enxergavam com simpatia a cultura estrangeira e com ressalvas, mesmo troça, a cultura legítima nacional e regional. O jovem crítico pretendia levar a palavra a "uma geração sem crença, inimiga do entusiasmo" ${ }^{42}$. Para Glauber, se esses jovens, na condição de homens de cidade, não conseguiam mais diferenciar entre aquilo que é o "conhecimento de nossa literatura e dos nossos costumes" ${ }^{43}$ e aquilo que é a cultura estrangeira com "pregação de um falso universalismo" ${ }^{44}$ é porque também eles, os jovens, não conseguiriam mais notar o vão entre o mundo urbano e o mundo rural brasileiro:

\footnotetext{
"Não floresceu no jovem do litoral a simpatia pelo homem brasileiro, pelo camponês, pelo vaqueiro, seringueiro; nem o jovem do litoral viu o operário que vai com ele no bonde ou o estivador que lhe descarrega as importações. O jovem também não viu o amor. Tornou-se maldito, desequilibrado sexual, machinho sem fibra. [...]

Vergonhoso que o romance brasileiro, principalmente o moderno, seja mais conhecido do público literariamente despretensioso do que por quantos, autosuficientes e envoltos no mais fácil e pretensioso verbalismo, já se presumem os renovadores de nossa literatura. Isso para não falar da inautenticidade em nosso teatro e cinema, para não dizer que o nosso sucesso popular apaixona mais que a honestidade e a convicção de um dever, sacerdócio literário. Uma coisa é realizar uma obra bem feitinha e outra é realizar uma obra conseqüente; o Brasil está cheio de literato frustrado macaqueando prolixidades nas colunas dos suplementos literários"45.
}

\footnotetext{
${ }^{41}$ Glauber Rocha, "Romance de José Lins do Rêgo", Mapa, Salvador (BA), ano 1, n. 2, 1957, p. 60.

${ }^{42}$ Glauber Rocha, "Romance de José Lins do Rêgo", Mapa, Salvador (BA), ano 1, n. 2, 1957, p. 59.

${ }^{43}$ Glauber Rocha, "Romance de José Lins do Rêgo", Mapa, Salvador (BA), ano 1, n. 2, 1957, p. 59.

${ }^{44}$ Glauber Rocha, "Romance de José Lins do Rêgo", Mapa, Salvador (BA), ano 1, n. 2, 1957, p. 59.

${ }^{45}$ Glauber Rocha, "Romance de José Lins do Rêgo”, Mapa, Salvador (BA), ano 1, n. 2, 1957, p. 59.
} 
Desde então, nos escritos de Glauber tornou-se recorrente o registro de certo impacto entre fazer uma "obra bem feitinha", no sentido de ela operar com o uso da boa técnica, com resultados mais kosmetikós que estéticos, e uma "obra consequente", esta, sim, preocupada com a renovação da prática artística de seu tempo e sua consequente modernização de parâmetros em relação à tradição. Por essa mesma perspectiva crítica, ampliou-se seu espectro de comentários e pode, em mais de uma vez e em distintos momentos, debater uma das teses mais importantes de seu pensamento político e estético: a distinção, as consequências e as fronteiras permeáveis entre uma arte comercial, voltada para a alienação dos seus receptores, segundo seus termos, e uma arte produzida nas cercanias do campo de produção erudita com ambiciosa atualização desse campo.

Retomo aqui, sob esse aspecto acima referido, um dos seus textos mais conhecidos, "Uma estética da fome", para comentá-lo tendo como pano de fundo o retrospecto desse artigo sobre José Lins do Rego.

Publicado pela primeira vez em português na famosa Revista Civilização Brasileira, dirigida por Ênio Silveira, esse manifesto de Glauber foi dirigido não só ao público de casa, mas também ao público de fora. Originalmente, foi preparado para ser apresentado como tese nos debates em torno do cinema na América Latina no seminário Terzo Mondo e Comunitá Mondiale, na V Rassegna del Cinema Latino-Americano, em Gênova, em 1965, e aqui ganhou repercussão, transformando-se num dos documentos de plataforma do Cinema Novo. Na ocasião da publicação no periódico brasileiro, atendendo a um pedido de Alex Viany, foram acrescentados comentários mais locais e menos genéricos no sentido de deixálo mais polêmico e informativo.

Grosso modo, se há um problema geral a ser identificado no teor do manifesto, esse problema se refere à diferenciação que Glauber - impactado, em parte, pelas leituras bastante correntes na época de Frantz Fanon ${ }^{46}$ - faz do olhar estrangeiro em relação a nós mesmos. Ainda que não só isso. Está em jogo também sua relação com a forma de arte que surge no mundo subdesenvolvido, naquilo que, nos anos 1960, tornou-se agenda entre intelectuais de diferentes manifestações do campo artístico e cultural de toda a América Latina. É emblemático o modo como Glauber equacionou o problema por meio de um

\footnotetext{
${ }^{46}$ Cf. Ismail Xavier, “Considerações sobre a 'estética da fome”, em Sertão Mar, 1983, pp. 153-67.
} 
dilema: "nem o latino comunica sua verdadeira miséria ao homem civilizado nem o homem civilizado compreende verdadeiramente a miséria do latino" ${ }^{\text {. }}$.

O que interessa aqui, todavia, é o ponto de contato entre "Uma estética da fome" e o problema inicial na abordagem e valoração do objeto artístico nacional proposto pelo ensaio "Romance de José Lins do Rêgo". Diante disso, me fixarei apenas naquilo que supostamente foi o conteúdo mais específico para o público brasileiro do manifesto, naquilo que foi deixado como recado e alerta das especificidades em relação à forma artística do cinema brasileiro defendida por Glauber e seus pares naquele momento de ampla movimentação, em meados dos anos 1960. No manifesto há uma predisposição de Glauber em demonstrar o empenho do Cinema Novo para se constituir uma "obra consequente" e não uma arte comercial, ou, em suas palavras, "o Cinema Novo se marginaliza da indústria porque o compromisso do Cinema Industrialé com a mentira e com a exploração"48.

Mas o "consequente" aqui, no manifesto, pode contemplar um significado parecido com o "consequente" lá, no ensaio sobre José Lins?

Sem que se faça uma generalização que possa levar a um entendimento evolucionista entre um e outro texto, na medida do possível, tudo leva a crer que sim. O "consequente" de um e outro compartilham de uma mesma motivação. Observe-se o paralelo. Quando Glauber, no texto de Mapa, critica a importação dos “ismos" e, por consequência deste fator, a desvalorização de obras como a de José Lins do Rego entre moços de sua geração, ele está demarcando um território de problemas e temas que se repetiriam mais tarde em seu manifesto. Segundo ele, "nosso jovem volta a adquirir um requinte já superado, encara o livro pela qualidade gráfica, o teatro pelos efeitos de luz, o cinema pela nitidez do som, etc., etc.[...] Hoje qualquer menino que leu um artigo ligeiro sobre Kierkgaard (sic) se enche de inteligência e passa a esculhambar, sem razão aparente, por esnobismo apenas, Euclides da Cunha, por exemplo”49. Só a obra consequente, da qual José Lins do Rego é figura modelar em sua visão de 1957, pode tirar o jovem dessa situação e leválo a encarar nossa marginalidade cultural e social.

\footnotetext{
${ }^{47}$ Glauber Rocha, "Uma estética da fome", Revista Civilização Brasileira, Rio de Janeiro (RJ), ano 1, n. 3, jul. 1965, p. 165.

${ }^{48}$ Glauber Rocha, "Uma estética da fome", Revista Civilização Brasileira, Rio de Janeiro (RJ), ano 1, n. 3, jul. 1965, p. 170.

${ }^{49}$ Glauber Rocha, "Romance de José Lins do Rêgo", Mapa, Salvador (BA), ano 1, n. 2, pp. 59-60.
} 
No texto de 1965, Glauber tem à frente outras circunstâncias pessoais dentro do campo artístico brasileiro. Aqui, o cineasta baiano já está valorizado por ser um dos participantes do Cinema Novo e lá fora todos querem ouvi-lo por ser considerado um autêntico intelectual latino-americano. Todavia, esses são fatores que não alteram, de modo substancial, seu ponto de vista sobre a necessidade de uma arte consequente. Só ela pode alterar o "raquitismo filosófico" e a "impotência" entre os setores artísticos nacionais. No seu exame da questão, ele mantém a mesma raiz para se pensar o problema, embora acrescente outros termos ao debate, desdobrando-os: nas letras do manifesto posterior há, por exemplo, a crítica ao condicionamento colonialista, que enxerga no processo de criação artística do mundo subdesenvolvido um modo de satisfazer a "nostalgia do primitivismo" para o homem do mundo desenvolvido; salienta a imagem da fome, tal como foi a terra e o homem na obra de José Lins do Rego apontada por Glauber no texto de Mapa, para encará-la não mais como a pecha do cinema brasileiro que desvaloriza a arte nacional, transformando-se, a fome e sua representação, a própria razão de sua existência artística, o "nervo de sua própria sociedade", e assim "o Cinema Novo narrou, descreveu, poetizou, discursou, analisou, excitou os temas da fome: personagens comendo terra, personagens comendo raízes, personagens roubando para comer, personagens matando para comer, personagens fugindo para comer, personagens sujas, feias, descarnadas, morando em casas sujas, feias, escuras: foi esta a galeria de famintos que identificou o Cinema Novo com o miserabilismo" ${ }^{50}$; por fim, esse mesmo condicionamento colonialista, que também é de base econômica e política, representou a causa da esterilidade e da histeria ${ }^{51}$ no campo de produção artística brasileira, surtindo motivos, entre outros, como a incapacidade de entusiasmo dos jovens, a mesma apontada no texto de Mapa. Se no artigo, sobre José Lins, Glauber só registra como esterilidade a falta de disposição e percepção da juventude baiana em relação ao que na verdade representou o moderno na arte brasileira, em seu manifesto de 1965 sua abordagem se amplia e seu foco recai sobre um exame mais amplo das causas. O jovem cineasta baiano não deixou de contemplar todos os setores da nossa arte:

\footnotetext{
${ }^{50}$ Glauber Rocha, "Uma estética da fome", Revista Civilização Brasileira, Rio de Janeiro (RJ), ano 1, n. 3, jul. 1965 , p. 167.

${ }^{51}$ Cf. Glauber Rocha, "Uma estética da fome", Revista Civilização Brasileira, Rio de Janeiro (RJ), ano 1, n. 3, jul. 1965, pp. 166-167.
} 
"aquelas obras encontradas fartamente em nossas artes, onde o autor se castra em exercícios formais que, todavia, não atingem a plena possessão de suas formas. $\mathrm{O}$ sonho frustrado da universalização: artistas que não despertaram do ideal estético adolescente. Assim, vemos centenas de quadros nas galerias, empoeirados e esquecidos; livros de contos e poemas; peças teatrais, filmes (que, sobretudo em São Paulo, provocaram inclusive falências). O mundo oficial encarregado das artes gerou exposições carnavalescas em vários festivais e bienais, conferências fabricadas, fórmulas fáceis de sucesso, vários coquetéis em várias partes do mundo, além de alguns monstros oficiais da cultura, acadêmicos de Letras e Artes, júris de pintura e marchas culturais pelo país afora. Monstruosidades universitárias: as famosas revistas literárias, os concursos, os títulos" ${ }^{32}$.

A permanência de certos temas debatidos por Glauber no final dos anos 1950 também contemplará outros textos do autor de Terra em Transe.

Veja-se outro exemplo: em 1966, Glauber escreveu o artigo "O Diretor (ou o Autor)" para o livro coletivo Cinema moderno, cinema novo, organizado por Flávio Moreira da Costa, e nele expõe seu entendimento de direção no cinema sob dois aspectos: um deles sobre o papel do diretor cinematográfico e sua relação com a figura do produtor de cinema; o outro, sua compreensão do diretor cinematográfico como autor, momento em que este está compromissado com a criação de obras consequentes.

Para Glauber, como mostra seu artigo sobre o autor de Menino de Engenho, a condição de constituição de um campo literário dependerá da circulação dessas obras e desses autores consequentes, para usar o seu termo de análise. José Lins do Rego, Jorge Amado, Euclides da Cunha são seus bons exemplos na literatura. Também enfileira seus maus exemplos. Sua interpretação mais ácida enquadra o que denominou escritores de "subliteratura", lugar de destaque para a francesa Françoise Sagan e o já citado Campos de Carvalho.

Como ele alçou vôos não só no campo da literatura, é momento de se perguntar: Que linhas de análise Glauber segue no artigo "O Diretor (ou o Autor)"? Nas suas discussões, o campo de produção e recepção de obras também está polarizado pelas obras de valor comercial e de valor erudito? Seria possível pensar a mesma questão, de maus e bons exemplos, em termos comparativos para o campo de produção no cinema? Isto é, segundo

\footnotetext{
${ }^{52}$ Glauber Rocha, "Uma estética da fome”, Revista Civilização Brasileira, Rio de Janeiro (RJ), ano 1, n. 3, jul. 1965, p. 166.
} 
sua opinião, haveria no caso do campo cinematográfico a mesma necessidade de defesa de uma obra e um autor consequente, como fez com José Lins do Rego?

Glauber responderia a esta última pergunta com um suntuoso sim. Para o caso do artigo "O Diretor (ou o Autor)", importa aqui saber que sua análise é implacável com o cinema de indústria (leia-se cinema como mercadoria) e o que nele estiver submisso (por exemplo, diretor submisso ao produtor que por sua vez está submisso ao sucesso de bilheteria e ao filme como comércio) e generoso com o cinema de autor, que, para ele, é o único meio possível de se extrair um valor de criação artística e, portanto, o seu modelo de bom exemplo. Um diretor como autor é seu único exemplo de artista dentro do campo cinematográfico passível de comparação com as figuras consagradas como José Lins do Rego ou Guimarães Rosa. Por esses motivos é que sua análise está sempre a reforçar que uma obra consequente só surge a partir de uma figura de autor, devendo ela não se ligar ao produto nem ao produtor da indústria cinematográfica, sob o risco de perda moral.

Em "Uma estética da fome”, Glauber aplica a importância da originalidade do autor para se pensar o processo cinematográfico nos trópicos, deixando seu alerta (e recusa) ao olhar exótico do colonizador, e em "O Diretor (ou o Autor)" ele aplica o exame do autor como premissa para se pensar um campo cinematográfico sem as amarras do cinema comercial, e, portanto, como possibilidade e alternativa para a ação dentro das fronteiras do cinema nacional. Em ambos os casos, tal como acontece com sua análise sobre o escritor paraibano em Mapa, Glauber explora que a dignidade da arte na vida social só é possível pelos mecanismos de circulação de obras prestes a demarcar sempre uma consciência de autoria, esteja esta travestida de literatura ou de cinema. José Lins é defendido por Glauber, porque é um autor. O mesmo ocorre com o diretor de cinema; só há defesa para aqueles que apresentam as características de autoria:

“[...] eu diria que um verdadeiro diretor de cinema é aquele que domina a técnica da consciência: este, no caso, é o mais avançado politicamente, é aquele que, se libertando da tirania do produtor assume sua própria tirania sobre o cinema, domina-o para colocá-lo a serviço do homem, como instrumento de desalienação, de denúncia, de análise e de agitação política nos momentos críticos da história. $[\ldots]$ 
O caráter de um verdadeiro diretor de cinema se mede, sobretudo, pela sua resistência diante das tentações da indústria. Nem só de filmes vive um diretor mas também dos silêncios a que se impõe para manter sua dignidade" ${ }^{33}$.

Feitos os comentários sobre esses dois textos, volto, de forma mais específica, ao artigo "Romance de José Lins do Rêgo". Chamo a atenção para a perspectiva focalizada por Glauber em um dos romances do escritor paraibano. Interessa compreender as razões pelas quais ele considerou Cangaceiros um dos romances mais bem acabados do escritor e quais seriam os efeitos disso em sua formação intelectual. Ao livro ofereceu boas páginas do seu ensaio e selecionou trechos para em seguida comentá-los. Se supor que essa escolha pode representar uma de suas aderências, tanto temática como formal, ao escritor paraibano e sua obra, isso pode ainda representar mais um dado explicativo para a apreensão dos aspectos formativos de sua trajetória como intelectual e pensador de nossa realidade.

É possível dizer que Glauber projeta sobre José Lins uma crítica impressionista, no sentido que, para ele, vale menos apresentar a visão de conjunto do escritor e sim transbordar sua própria visão e no que esta se modificou com o conjunto da obra do escritor. Desde o início, ele procura deixar claro que José Lins é escritor compatível com seu próprio pensamento. Compatível com um nacionalismo sem demarcação ufanista, pois como observou o jovem crítico "conhecer o Brasil e seu tema e sua cultura e sua história e sua sociologia não é ufanismo" 54 .

A começar pelo tipo de romance, José Lins é visto como um escritor que lida com o complexo do Nordeste, ocupa-se, sobretudo, pelo aspecto da vivência e da experiência própria, como autor, dessa realidade. Não é a terra distante que é a base de seu romance, mas a terra onde o escritor viveu e rastreou todas as minúcias documentais da situação de decadência de uma aristocracia local. Para Glauber, José Lins é a marca viva, portanto sua explicação fundamental, de uma época dos engenhos e dos valores locais nordestinos. Em sua visão, trata-se de um escritor da literatura brasileira mais importante que o próprio Euclides da Cunha e seu Os Sertões para o entendimento do homem do Norte, pois nele "encontramos uma estrutura humana mais bem aparelhada, um mergulho na raça mais sofrida, menos frio, mais vivenciado" ${ }^{" 55}$. Ele encontra no escritor uma análise pela via da

\footnotetext{
${ }^{53}$ Glauber Rocha, "O Diretor (ou o Autor)", em Cinema moderno, cinema novo, 1966, pp. 51-52.

${ }^{54}$ Glauber Rocha, "Romance de José Lins do Rêgo", Mapa, Salvador (BA), ano 1, n. 2, 1957, p. 60.

${ }^{55}$ Glauber Rocha, "Romance de José Lins do Rêgo", Mapa, , Salvador (BA), ano 1, n. 2, 1957, p. 61.
} 
tragédia que vai da "feliz" vida dos meninos nos engenhos até a decadência com o aparecimento das usinas e suas produções em massa, passando pela vida do cangaço no meio do sertão e do misticismo desse homem. Se ainda por cima não tem a "aridez do mestre alagoano [Graciliano Ramos]" ou "os propósitos políticos de Jorge Amado"56, é porque seu lirismo conseguiu adequar, segundo Glauber, uma forma perfeita de análise social e compreensão ficcional daquele homem e daquela terra.

Não é novidade que há no jovem Glauber a preocupação pelas coisas do Nordeste. Para ele, é vital demonstrar interesse por um autor que tivesse, sob seu olhar, conjugado a qualidade literária com o empenho no caráter documental nordestino. Como se pode observar nas notas finais do texto, em que o crítico baiano estabelece quais são os autores consultados da fortuna crítica de José Lins, é bem possível que ele estivesse excitado pelas leituras empenhadas de escritores e críticos sobre a obra do escritor. O leque era amplo: Mário de Andrade, que havia frisado em o Empalhador de passarinhos a importância do romancista de Fogo Morto, é contemplado no artigo por mais de uma vez. É referência não só como fortuna crítica de José Lins, mas também é evocado pelos versos de $O$ carro da miséria: "Enquanto isso os sabichões / discutem se dôce-de-abóbora não dá chumbo pra canhão"; Otto Maria Carpeaux, Álvaro Lins e Franklin Thompsom e suas ideias contidas num livrinho de 1952 organizado pelos três autores e que se chama José Lins do Rêgo; pelas ideias contidas no livro de autoria do próprio José Lins, sob o título Presença do Nordeste na Literatura Brasileira, de 1957, e ainda o teor bastante polêmico do "Manifesto Regionalista" de Gilberto Freyre, o qual Glauber, ao que tudo indica, deve ter lido via o livro dos três autores acima referido ou o livro de críticas de José Lins. Em ambos o manifesto é retratado.

Importa mesmo sublinhar que Glauber estava impregnado das coisas do Nordeste. E continuou assim marcado por um bom tempo. Seus dois primeiros filmes, Barravento e Deus e o Diabo na terra do sol, respectivamente de 1962 e 1964, continuam o tratamento temático: há em ambos a fisionomia do homem do Nordeste e seu problema com a terra (sentido do espaço e seu problema da apropriação, já que em Barravento a questão se passa pela exploração do mar e em Deus e o Diabo pela exploração da terra, entre outras coisas).

Voltando ao caso dos seus comentários para o livro Cangaceiros (1953), Glauber vai encontrar na obra um modelo de composição de personagens, pois a técnica perfeita,

\footnotetext{
${ }^{56}$ Glauber Rocha, “Romance de José Lins do Rêgo", Mapa, , Salvador (BA), ano 1, n. 2, 1957, p. 61.
} 
segundo ele, passa pela habilidade do escritor em por "o que tem a contar na boca de seus personagens" ${ }^{\prime 57}$. Assim, Glauber parte para definir Cangaceiros em seus aspectos de obra de ficção que ensaia o problema social do nordeste brasileiro: "é [...] no fundo uma conversa geral ou, no conjunto, o grande monólogo do próprio nordeste. A amargura, o cansaço, o desespero de injustiçado capitão decadente que lamenta o filho apunhalado pelos jagunços de um temoroso Cazuza, insinua-se como doloroso contraponto, como um pêndulo cruel a ritmar o sangue facilmente ritmado $[. .].]^{\prime 58}$. Dentro desse mundo, o que o atrai, sem dúvida, é o personagem Aparício Vieira. Para Glauber, um herói invencível que vive na boca do povo e guarda o misticismo de santo ou demônio. Trata-se de uma fisionomia composta a partir dessa heroicidade:

“[...] mesmo decapitado e assim exibido por toda a terra, continuará vivo nas feiras, nos abecês populares, nas histórias dos velhos. Aparício Vieira é mais um integrante da geração inaugurada pelo lendário Cabeleira, dignificada por Antonio Silvino, tristemente encerrada por Virgulino Lampião. Aparício é esse herói brasileiro em sua dimensão literária. Quando surge em 'Cangaceiros' já traz uma glória, envolve-o uma sombra de medo, coragem, invencibilidade, sangue, vingança, bem. Cavalga virilmente, traz rifle e punhal, ornamenta-se com requinte, anéis nos dedos, chapéu de couro bordado, cinto de fivela, alpercata trabalhada. Rica de caracteres exteriores, a representação plástica do cangaceiro avulta mais sugestiva e imponente que a dos bandoleiros norte-americanos vistos nos filmes de 'western' ou de qualquer outro bandido ou revolucionário de outra parte do mundo que agisse em campo, a cavalo, a arma branca e arma de fogo" 59 .

Como o jovem crítico está a estabelecer uma leitura de Cangaceiros que leve irremediavelmente a uma visão do sertão entre os domínios do misticismo e do cangaço, nos limites entre o santo e o guerreiro, é bastante plausível que escolhesse como imagem central do romance a cena em que Aparício Vieira, deixando o rifle cair e ajoelhando-se em frente ao Santo, primeiro se põe a receber suas bênçãos e depois, possuído de fúria, ergue-se e com o rifle em punho, na mão esquerda, fita o Santo, puxando a seguir, com a mão direita, o punhal da bainha ${ }^{60}$.

\footnotetext{
${ }^{57}$ Glauber Rocha, "Romance de José Lins do Rêgo", Mapa, Salvador (BA), ano 1, n. 2, 1957, p. 68.

${ }^{58}$ Glauber Rocha, "Romance de José Lins do Rêgo", Mapa, Salvador (BA), ano 1, n. 2, 1957, p. 68.

${ }^{59}$ Glauber Rocha, "Romance de José Lins do Rêgo", Mapa, Salvador (BA), ano 1, n. 2, 1957, pp. 68-69.

${ }^{60}$ Cf. José Lins do Rego, Cangaceiros, 1976, p. 8.
} 
Glauber idealiza o cangaceiro como o personagem mais original da terra sertaneja. No artigo sobre José Lins, ele enxerga esse personagem-tipo sempre em tom melancólico e vivendo o mundo da lenda no sertão, na corda bamba entre aderir aos poderes do messias do sertão, e, portanto, aos poderes de Deus, ou aderir compulsoriamente ao mundo da violência que o levaria a sair ou a sucumbir na própria terra. Não é o elemento ou o tom natural das ações dos personagens que Glauber assumirá no futuro, mas aquilo que constitui a teatralidade dessa lenda e seu dilema popular: não nega a violência do sertão e não nega a crença na força divina. Este é o tecido histórico que busca interpretar, seja na ficção do outro, seja na constituição de sua própria ficção.

É certo que do universo da cena do romance, caracterizando um aspecto de Aparício em Cangaceiros, ou seja, de um homem que vive em meio ao mundo da fé e da violência, Glauber vá extrair algumas semelhanças para a composição, mais tarde, de seus personagens com traços e ligações com o cangaço ou a vida sertaneja. Exemplos não faltam e merecem ser aqui arrolados. Veja-se o caso, no seu filme Deus e o Diabo na terra do sol, do personagem Manuel e sua adesão ao cangaço, conduzido junto com Rosa, sua mulher, pelo Cego Júlio para se ligar à Corisco, este um legítimo herdeiro de Lampião.

Manuel, enquanto personagem do cangaço, opera com os mesmos termos apontados por Glauber em sua leitura de Cangaceiros de José Lins. Porque há nele, no personagem do filme e do livro, como princípio que o norteia, um dilema a ser vencido dentro da própria alienação a que está sujeito: precisa encontrar um projeto de salvação e mudança de seu destino social. A história desse personagem do filme, já sublinhada pelo melhor da fortuna crítica de Deus e o Diabo, pode ser analisada pelas três passagens ou rupturas $^{61}$ entre os mundos do sertão: da vida de homem explorado pelo grande proprietário de terra ao homem violento e integrado ao banditismo, passando antes, porém, pela vida de beato. Em análise miúda, o desdobramento do enredo deu-se assim: depois de deixar sua vida de vaqueiro, Manuel adere primeiro ao mundo messiânico junto a Sebastião, o santo que é morto por Rosa, para em seguida encontrar Corisco e fazer o seu segundo pacto, agora com o mundo do cangaço.

Para a representação da ambiguidade vivida por esse personagem, escolho como emblemática a sequência em que Corisco e seu grupo (já com Manuel) invadem a fazenda do

\footnotetext{
${ }^{61}$ Cf. Ismail Xavier, Sertão Mar, 1983, pp. 69-119.
} 
Coronel Calazans. Dessa sequência, logo após uma breve descrição da sua composição, extrairei meus comentários seguintes.

Ali está bastante evidente - e o ponto de vista criado pela narração no filme confirma isso - a fissão vivida entre os dois projetos de vida pelo personagem Manuel, sua experiência religiosa de crença na salvação e, consequente, mudança de trajetória para uma vida beata, e sua experiência da irremediável violência com que é forçado naquele mundo do sertão. De início, como ritual de passagem, Manuel, diante da opção pelo cangaço, recebe um novo nome dado por Corisco. Chama-se agora Satanás, personagem que tinha como primeira missão junto aos demais o assalto à casa do coronel, que, segundo Corisco, era homem ligado aos donos do poder, à "gente do governo". O som de um violino estridente, quase beirando o atonalismo, levando à noção de uma ruptura de tempo em relação ao quadro anterior, pontua o início da sequência. Num primeiro plano, nota-se o enquadramento de um bolo, rudemente esfacelado pela mão de Manuel-Satanás, reconhecese em seguida. Ainda em segundo plano, visualiza-se alguém sendo agredido a chicote, demonstrando que o assalto já havia começado de fato. A câmera na mão roda pela casa, ora aproximando-se mais de uns, ora flagrando mais outros, e apresenta quem são os personagens em cena: Rosa, com expressão assustada e acompanhada de Cego Júlio, passa, súbito, em frente à cena sem ao certo saber o que procura; em seguida, o corte se faz para Corisco, que logo após a clara recusa dos fatos por parte de Dadá, sua mulher, ele começa sua violência sexual contra a personagem que se supõe ser a mulher do tal coronel. A cena da violência perde lugar para Manuel, que invade o espaço cênico. Após um rápido giro a demonstrar a nova disposição dos personagens (Cego Júlio andando, Rosa e Dadá apreciando adornos que haviam roubado e Corisco em luta com a mulher a ser violentada), a câmera mais uma vez se fixa em Manuel. Ele está agora parado diante da imagem de Jesus Cristo na cruz num pequeno altar de madeira. Num impulso do personagem, com a câmera a acompanhá-lo e sob o que parece ser os gritos da mulher violentada, Manuel empunha a cruz, ritual que demonstra ainda que o homem de fé-messiânica ainda sobrevive naquele que já se traveste de homem da violência e do cangaço. Começa um novo som, o violino parece acompanhar a adoração do personagem frente à imagem religiosa. Em seguida, a câmera fixa acompanha o ritual de carinho entre Rosa e Dadá, que logo perde lugar para o ritual de Manuel. Ele carrega uma cruz entre as mãos, repetindo o gesto de Sebastião, quem ele seguia e adorava antes da entrada no cangaço. O gesto, bem como o fim do som de violino que 
acompanhava o ritual, é interrompido por Corisco. A câmera fixa flagra o silêncio, sinal do confronto entre os dois personagens de cena: Corisco e Manuel. À cena é incorporado o suposto marido da vítima violentada trazido por dois cangaceiros. Novamente se faz um novo confronto entre Corisco e Manuel, quando este último é solicitado a castrar o tal homem, o que lhe obriga o cangaceiro-chefe: "Satanás, mostra que tu já é um cabra bom. Corta a macheza desse corno!", oferecendo em seguida a faca a Manuel. Com a faca na mão direita e a cruz na esquerda, o personagem opera aquilo que poderia ser considerado seu emblema maior: a vida sertaneja entre os dois mundos. Naquele momento de dilema, a câmera muito mais próxima afasta-se e projeta uma nova perspectiva. A abertura do zoom da câmera estilhaça a ruptura do pobre sertanejo. Corisco retira a cruz de uma das mãos de Manuel, enquanto os dois cangaceiros seguram a vítima. E Manuel, sem piedade, cede ao violento pedido. Dos elementos sonoros, extraídos da movimentação apenas de objetos e de pessoas em cena, dá-se lugar a uma nova instância de narração: a música de tonalidade épica. Fechava-se, assim, o cerimonial de passagem da ação de Manuel-beato para a ação de Manuel-cangaceiro, que, entre outras coisas, pode ser interpretada como uma nova perspectiva adotada pelo personagem em sua tentativa de sobrevivência no mundo duro do sertão.

Dito de outro modo, é evidente que a figura de Manuel não apresenta as mesmas linhas de constituição do personagem Aparício levantado por Glauber em Mapa, não sendo, portanto, seu espelho. Eu não quis em nenhum momento demonstrar isso; pode beirar à ingenuidade. Interessa aqui sublinhar o grau de comparação entre os dois universos: de José Lins e Glauber. E, enquanto jovem intelectual, como Glauber resolveu assinalar um aspecto que mais tarde pôde ser prolongado como atitude crítica frente à formulação do seu próprio projeto ficcional revestido de um ensaísmo de interpretação junto ao mundo sertanejo. Aparício é assinalado por Glauber como personagem requintado naquele universo sertanejo. Um requinte que, na obra do autor de Deus e o Diabo, pode ser visto em Corisco - pelo menos em termos de vestimentas, ornamentos e mesmo crueldade. Já o personagem Manuel é mais emblemático como prolongamento desse universo sertanejo retratado e destacado pelo Glauber analista do romance de José Lins. Assim, não é à toa que ele tenha escolhido de Cangaceiros de José Lins justamente a cena em que estão representados lado a lado os valores da crença divina e os valores da prática do cangaço. Em seu projeto de composição de seu personagem Manuel, Glauber procurou visualizar sua solução exatamente nessa fissão entre 
uma e outra coisa: universo popular e violência de um mundo degradado pari passu com uma representação de arte moderna. Eis, talvez sua principal conexão com o modernismo de José Lins.

Foi dito até o momento que o cangaço, fonte de interesse de Glauber pelo romance Cangaceiros, tem sua ressonância em seu segundo filme, isto é, em 1964. Antes desta data, no entanto, ele já demonstrava sinais de aproximações com o tema. Basta notar a primeira versão do que viria a ser o roteiro de Deus e o Diabo, escrito em 1959, com o título provisório de "Ira de Deus". Não entrarei nas minúcias desse roteiro, e sobretudo nas características de composição do personagem Corisco, mas basta dizer que há indícios, por sinal muito convincentes, de que a ideia do título passa diretamente pela leitura desse romance de José Lins. A pesquisadora Josette Monzani, em competente estudo sobre o percurso genético de composição do filme, aponta quatro trechos do livro do escritor paraibano para supô-los como fontes de inspiração para o título da primeira versão do roteiro, em que a ideia de um castigo divino paira sobre o universo do sertão ${ }^{62}$.

Nesse percurso pelo cangaço, Glauber ainda deixou outros rastros. Valem aqui como lembrança, pois demonstram que seu interesse pela vida do cangaço e a violência no sertão vinham de longa data e, sob tais circunstâncias, continuariam a ser importante fonte de suas preocupações intelectuais no novo decênio que vinha.

Em 21-22 de fevereiro de 1960, Glauber foi autor de uma grande reportagem dominical em que focalizou Corisco ${ }^{63}$. Em sua investigação, conseguiu entrevistar o major José Rufino, o homem que matou Corisco em maio de 1939. Outro registro vem do Centro de Documentação da Cinemateca, em São Paulo, local onde se encontra parte do arquivo pessoal de Glauber. Numa das pastas de seus recortes, espécie de hemeroteca particular do escritor, pode-se verificar o flagrante desse seu interesse. De tudo que provavelmente leu e guardou sobre o cangaço, sobraram três recortes de jornais em que constam grandes reportagens ${ }^{64}$ publicadas em jornais baianos. Numa delas, datada de janeiro de 1950, portanto

\footnotetext{
${ }^{62}$ Cf. Josette Monzani, Gênese de Deus e o Diabo na Terra do Sol, 2005, p. 29.

${ }^{63}$ Cf. Glauber Rocha, "No roteiro do cangaço repórter DN descobre Corisco", Diário de Notícias, Salvador (BA), 21-22 fev. 1960, p. 7.

${ }^{64}$ Cf. Bruno Gomes, "Como se forja um cangaceiro: Corisco, o diabo louro", Diário de Notícias, Salvador (BA), 08 mai. 1959; Bruno Gomes, "Como se forja um cangaceiro: um cabra covarde", Diário de Notícias, Salvador (BA), 14 mai. 1959; Berliet Júnior, "Meu minuto trágico: Corisco quando brigava se parecia com o demônio", Estado da Bahia, Salvador (BA), 23 jan. 1950.
} 
quando ele estava com apenas 11 anos, dá-se prova, ao menos se faz supor, que o interesse pelo cangaço por parte de Glauber vinha de longa data em sua vida.

As reportagens, sejam elas preparadas pelo próprio Glauber, sejam elas escritas por terceiros e guardadas pelo cineasta baiano, só reforçam seu leque de interesse por aquilo que seria a marca mais real daquele universo. Nesse horizonte, a obra de José Lins do Rego vinha como uma luva para seus interesses juvenis, pois se apresentava como retrato, pela via moderna, desse universo nordestino que o tocava profundamente desde longa data. $\mathrm{O}$ escritor paraibano lhe oferecia um exemplo de como se fazer o equilíbrio entre a análise do fenômeno social (leia-se sociedade patriarcal em decadência) e a prática de uma arte moderna.

Para finalizar meus comentários, esboço, mesmo que sumariamente, algumas razões sobre as quais penso ser bastante estratégica a postura de Glauber naquele momento, ou seja, quando lança mão de afinar ideias de um escritor modernista de primeira ordem com as suas propostas iniciais de explicitação de um projeto intelectual. Escolher o autor de Fogo Morto como tema de um ensaio trouxe para Glauber uma marca de distinção em relação aos demais jovens intelectuais do campo artístico baiano. Em outras palavras: na base de seu ensaio sobre José Lins, estava ele não só promovendo um tipo de arte moderna que ligava, sem as amarras acadêmicas, o homem (e sua via popular) e sua própria terra, mas também estilhaçando o emblema de "arte pela arte". Naquele momento de sua morte, José Lins já era um escritor moderno canonizado pela crítica. Autor visto com bons olhos sob os crivos exigentes de Mário de Andrade a Carpeaux. Glauber deseja aderir o escritor de Menino do engenho ao seu próprio projeto intelectual. Glauber quer que seu projeto intelectual se identifique com José Lins. Enfim, em sua estratégia está a conexão entre as ideias dessa forma de arte moderna sobre o universo nordestino, presente em José Lins, e a sua forma de pensamento sobre a arte mais adequada à nossa realidade.

Glauber parte do princípio: sou um intelectual moderno e vivo e cultuo aquilo que é moderno e da terra, sendo eu o desdobramento de certas linhas de autores e obras dentro do campo literário contemporâneo. Então, o jovem crítico baiano se valorizava enquanto intelectual na medida em que se colocava como herdeiro da tradição de José Lins, que a crítica literária a reconhecia como própria do romance social moderno. 


\section{Visão sobre o Western e a lição do filme mexicano}

Como assinalei lá no início, a revista Mapa apenas alcançou três exemplares. Ativo participante do processo de sua edição, em todos, Glauber contribuiu com textos de interpretação sobre os fenômenos artísticos contemporâneos. Se o artigo sobre José Lins publicado na número 2 é, sem dúvida, o que o jovem crítico mais escreveu, empenhando-se por longo tempo na escrita de extensas páginas de análise e interpretação do escritor paraibano, os outros dois artigos restantes deixam entrever um aspecto comum de suas motivações intelectuais, pelo qual se pode comentar e interpretar o saldo dessa sua empreitada.

Em ambos os casos, seja quando Glauber escreve sobre o Western, caso do artigo de Mapa 1, seja quando escreve sobre o cinema mexicano, caso do artigo de Mapa 3, ele considera que uma visão interpretativa do Brasil para ser mais completa necessita também contemplar o aspecto comparativo com outras formações discursivas e de linguagens. É desse modo que considera necessário discutir e às vezes buscar o estímulo em outro campo artístico que não o de sua realidade. Como um legítimo analista comparatista, Glauber escreveu sobre literatura com a intenção de lançar argumentos para a arte cinematográfica, escreveu sobre outras cinematografias para esboçar argumentos e assim pensar a nossa própria cinematografia.

Cabe abordar cada um dos dois artigos para discutir o modo como se deram essas incorporações e como elas refletiram na discussão da própria visão que o jovem tinha naquele momento sobre o Brasil. Fixarei a maior parte do esforço no artigo sobre o western americano.

Em 1957, o primeiro número de Mapa estampava o artigo de Glauber “O western - uma introdução ao estudo do gênero e do herói”. Como o próprio título indicava, as preocupações do cineasta baiano se voltavam para o gênero mais típico americano, o filme de faroeste ou de bangue-bangue como aqui ficou conhecido. Dividido em três partes, e não tão longo quanto o artigo sobre José Lins, o texto basicamente faz uma espécie de caracterização do gênero, discute sua formatação dentro da realidade do cinema americano e finaliza com uma reflexão sobre o papel do herói no western e como suas transformações interferem e modificam o próprio gênero. Destaco aquilo que considero uma longa cena de caracterização 
do gênero feito pelo jovem crítico. Embora seja uma longa citação, merece aqui ser destacada, pois por ela alinharemos nossos comentários seguintes:

"O chapéu é de largas abas, o revólver de balas intermináveis é sacado com a velocidade do raio, o cavalo é preto ou branco e é fiel até o último perigo, os punhos são fortes e ágeis. A estrela no peito é o símbolo do bem.

O cowboy vem de onde o homem ou menino não sabe; surge lá no fim da pradaria sob a quentura do sol, varando a cortina seca de poeira. Cantarola às vezes; é uma cantiga triste, fala para uma mulher, fala de uma terra...

O cavalo vem trazendo o homem até o primeiro plano e o mito cresce e se realiza. Os tiros surgem tão inexplicavelmente quanto ELE. A diligência perseguida leva uma mulher bonita, leva um caixeiro-viajante, leva um homem mau granfino da cidade trazendo o pecado para o oeste. Os bandidos mascarados - às vezes com panos pretos nas caras, às vezes com penas e tinturas de guerra - precisam ser derrotados. ELE saca os revólveres, dispara certeiramente, cada tiro é uma queda certa. A canção agora já não está em seus lábios; saindo da alma do herói, ganha o tempo, domina a pradaria, é uma variação ao ritmo das balas.

O mal não resiste a ELE. Fogem os bandidos. Voltarão depois para nova refrega. ELE é galante, conquista o coração da mocinha e desperta o ódio do homem mau, ganha a simpatia do caixeiro-viajante.

Na cidade ELE é o ídolo das crianças. Porque uma delas é morta, ele põe a estrela no peito, invade o saloon pelas portas balançantes, dá um tiro na luz, vira a mesa de jogo, briga com três, quebra a cara do valentão. O chefe o desafia para um duelo. Ele é corajoso. Pelo coração da mocinha, pelo bem, e por causa da admiração das crianças, e muito mais, pela importância do mito que não pode ser quebrado, porque todos os homens confiam cegamente na infalibilidade do herói, ELE aceita o duelo mesmo sabendo de uma emboscada, mesmo com a certeza de várias armas escondidas apontando às suas costas.

A aurora em desenvolvimento situa a ruazinha deserta. Aquela música triste temendo pelo herói. ELE surge; caminha firme, os olhos para um direção bem longe. O momento vale um gesto quase imperceptível terminado pelos disparos sucessivos. A música hesita, os corações de homens e de meninos afastados do mundo no refúgio da sala escura param por um segundo.

Quando o homem mau dobra o corpo e cai, um sorriso de libertação dos homens e das crianças.

ELE está indiferente. Tira a estrela do peito, monta o cavalo preto ou branco, deixa uma mulher amada e some no fim da pradaria e no fim do mundo. 
Os homens e os meninos estão alegres por ELE venceu mais uma vez. Voltará na próxima semana para novas apreensões e novas libertações” ${ }^{\prime 65}$.

A caracterização do jovem crítico é precisa, não deixando de ser afetiva e crítica diante do seu objeto. Sem hesitações e com requintes de composição, demonstrando não só a caminhada do herói, mas também a do seu público diante dele, a descrição agrupa todos os elementos de cena de um filme faroeste. Seu fio condutor é o herói, sempre ele. É ele quem saca a pistola e enfrenta o quente meio-dia diante da morte. Apesar de seus poucos 18 anos, Glauber demonstra ser leitor inteligente e estratégico, que não está preocupado apenas com o processo de encadeamento de ações. Importa para ele, e talvez isso seja o mais relevante aqui, o modo como se dá a montagem e o processo dessa narrativa.

Coloco em destaque dessa descrição três aspectos que o texto do jovem Glauber levanta sobre o western: o mito da infalibilidade do herói; a construção mítica do espaço das fronteiras; a nova missão que se renova, uma após a outra, marca da previsibilidade do herói diante do seu público fiel e constituído de uma massa heterogênea de espectadores.

A descrição inicial do herói é marca dessa sua infalibilidade. Sempre alinhado nas vestimentas, ele leva consigo um revólver sem igual, com "balas intermináveis". O instrumento em si, porém, não significaria muita coisa, não fosse a agilidade e habilidade do manejo de seu dono. É a segurança para mocinhas e crianças diante do banditismo generalizado de um suposto mundo sem-lei e sem ordem. Sob a tutela do Estado em formação, recebe para si a missão de levar a paz nas terras da desordem. O símbolo maior dessa missão é a estrela do bem estampada no peito. É a fantasia construída de uma infalibilidade de um herói para a configuração do próprio mito nacional da superação diante do outro. Versátil, esse herói, antes de ser um sujeito da ordem, é a marca viva do processo civilizatório, num esquema, por assim dizer, maniqueísta, em que se agrupa de um lado a moral cristã, com seus homens de bem, e de outro o lado do mal, contrário ao processo colonizador e à demarcação de espaços territoriais e de identidades definidas. Por dentro dessa missão do herói, o crítico tem a consciência de que é ela quem demarca a afinidade de seu público com o cinema americano. Para Glauber, esse herói, muitas vezes esquemático e sempre muito adorado, é a marca do filme americano. Portanto, ele, o herói-personagem,

\footnotetext{
${ }^{65}$ Glauber Rocha, "O western - uma introdução ao estudo do gênero e do herói”, Mapa, Salvador (BA), ano 1, n. 1, 1957, pp. 18-19.
} 
carrega consigo as marcas de identificação plena com aquela cultura do passado, que revive e constrói o presente de uma nação.

Também é consciência do jovem crítico que o espaço onde esse herói transita é tão importante para a construção do gênero western, tanto quanto suas ações de personagem. O espaço compõe e dispõe, feito tabuleiro de xadrez, as peças para a construção dos mitos, tanto do herói como do gênero por excelência americano. Se são os grandes vales e as pradarias que descortinam o herói para o público, iniciando suas ações mais envolventes, são esses espaços que também encaminham o herói para outra missão desconhecida ao final. $\mathrm{Na}$ câmera que se abre em panorâmica, deixando o herói como elemento solitário e nanico diante da imensidão do território, sugere-se ao público a dimensão da investida histórica feita no passado. Era necessário constituir fronteiras para a permanência bem sucedida daquela moral cristã estabelecida na América. Apenas um herói, com aquelas características e vigor, poderia comportar o fardo diante do inóspito espaço desconhecido. Seu aspecto original dependerá do tema, que dependerá do melhor modo de exploração do espaço cênico constituído. Mais do que o espaço de fronteiras geográficas, importa mesmo é a ambientação a que o seu personagem principal está sujeito dentro das quatro linhas de enquadramento. Que fique claro que ambientação aqui é no sentido que Osman Lins consagra, em nível teórico, no seu clássico estudo sobre o espaço no romance: "Por ambientação, entenderíamos o conjunto de processos conhecidos ou possíveis, destinados a provocar, na narrativa, a noção de um determinado ambiente. Para aferição do espaço, levamos a nossa experiência do mundo; para ajuizar sobre a ambientação, onde transparecem os recursos expressivos do autor, impõe-se um certo conhecimento da arte narrativa" ${ }^{\prime 66}$. Em outra parte do artigo, o jovem crítico expõe o valor do espaço, e por consequência o da ambientação, para o gênero, e mais do que isso, ressalta o caráter de constituição original do espaço para o cinema americano:

“Tema genuinamente nascido durante a expansão territorial e a colonização dos Estados Unidos, legou aos cineastas de Hollywood esta singular possibilidade de trabalhar com a matéria que, dado o seu caráter estritamente regional, não poderia sofrer a exploração de outros cinemas" ${ }^{\prime 67}$.

\footnotetext{
${ }^{66}$ Osman Lins, Lima Barreto e o espaço romanesco, 1976, p. 77.

${ }^{67}$ Glauber Rocha, "O western - uma introdução ao estudo do gênero e do herói", Mapa, Salvador (BA), ano 1, n. 1, 1957, p. 21.
} 
Como último aspecto a ser abordado, Glauber analisa o público maciço do western. Gênero de mocinho e bandido, é a previsibilidade das ações do herói que constitui o elã entre público e filme faroeste. A previsibilidade do personagem, composta pelo seu aparecimento, diante da mocinha, seu estabelecimento no vilarejo, sua ação novamente contra os bandidos e sua indiferença e, por fim, seu desaparecimento na paisagem, é o que formula as etapas de apreensão do seu público. Ser menos ou ser mais bem sucedido, no caso desse tipo de filme, dependerá de como cada etapa se encaixa com as demais. Ainda que muito suave, o crítico deixa escapar nas suas entrelinhas que o público que ele nota é tãosomente um espectador preocupado com encadeamento lógico das ações do herói, com a catarse de cada cena contida no clímax de cada etapa da narrativa. Nesse tipo de apreensão por conta da recepção de um específico espectador, misto de alienação e força de uma cultura sobre outra, Glauber vai centralizar sua crítica mais ácida. Vem ao caso a lembrança, ainda que de modo sumário, de um outro texto seu de 1957, em que faz uma análise, pari passu com esta, sobre a inserção e relação do cinema americano em outras praças. Utilizo este texto mais tarde modernizado pelo autor e incluído em $O$ século do cinema, mas que originalmente, sob o título "Pregação da violência no cinema americano", foi publicado no suplemento literário Sete Dias, de Vida Capixaba:

"Tem Hollywood o objetivo de atingir o coração do grande público e the conquistar simpatia e preferência. Partindo do pressuposto de que o homem de classe média quando entra no cinema procura uma fuga e não espelho da realidade, os produtores capricham nos clichês de entorpecimento e retiram o público do social para o alienante fantástico.

A usina de sonhos produz esperança infantil e insufla a consciência de guerra.

Há subestimação da solidariedade humana e simpatia exagerada pela moral ensinada.

O cinema deixa sua função cultural e assume o papel deseducador.

O público elegeu seus 'Heróis' e não cede lugar ao aparecimento de outros.

Daí a frustração do herói neo-realista cheio de pecados e debilidades, que não serviu para propagandista do capitalismo derrotado. A estrutura do herói americano era outra.

Vencera a guerra e era forte.

$\mathrm{O}$ italiano perdera.

O público infelizmente, não vê e não sente as causas da influência. 
É o fanatismo coletivo que submete parte do mundo aos Estados Unidos.

Com o aparecimento do cinemascópio o filme violento adquiriu um requinte de técnica que acentua a falsidade e sentido de provocação.

Hollywood perdeu a 'forma'e adquiriu a 'fórmula'”68.

Apesar das ressalvas com o cinema americano e sua base colonizadora tão criticada por ele, Glauber ainda enxerga o western como uma contribuição original para o cinema mundial. Se o americano se vê, de corpo e alma, revestido daquela história formativa e, portanto, repleta de valor identitário para ele, o caso do brasileiro, e Glauber sabe disso, é com as ações do herói e sua dimensão mítica. Mas por quê? Nessa linha, ao tentar encontrar uma explicação para o sucesso aqui do gênero, o jovem crítico estabelece algumas possibilidades para se pensar o western e seu sucesso de público em nossas terras. A explicação mais plausível, encontra ele, está na própria transformação estilística do western. A opinião de Glauber sugere certa originalidade com o gênero, pois é a primeira vez que o cinema opera por ele mesmo, com o mínimo de acesso às outras artes para sua própria composição e, desse modo, ganha um "caráter autônomo perante às outras manifestações artísticas ${ }^{\prime 69}$. Portanto, trata-se de um fator que tem suas raízes na própria dimensão da forma do filme. Sem seu peculiar mecanismo de corte e montagem, por certo, seria um gênero não tão bem sucedido por aqui. Ele lembra ainda de outro fator, não menos importante e ligado ao anterior: a persistência com que o gênero se manteve vivo ao longo do tempo, podendo seus cineastas investir na exploração e diversificação da forma do gênero. Vai dizer o crítico, sem exageros e talvez tomado pela própria experiência juvenil de frequentador de salas de cinema: "Poderíamos afirmar que o homem do século XX cresceu à sombra do herói criado por Hollywood"70.

Entre o final dos anos 1950, quando escreve o artigo de Mapa, e o início dos anos 1960, Glauber já vive um período de muita contribuição na imprensa. Além de escrever sobre quase todos os filmes que circulavam nos cinemas de Salvador, também iniciava suas primeiras colaborações em jornais do Rio de Janeiro. As produções quase diárias de artigos faziam com que o crítico se debruçasse sobre tudo que estivesse no circuito de cinema

\footnotetext{
${ }^{68}$ Glauber Rocha, "Pregação da violência”, em O século do cinema, 2006, p. 68.

${ }^{69}$ Glauber Rocha, "O western - uma introdução ao estudo do gênero e do herói”, Mapa, Salvador (BA), ano 1, n. 1, 1957, p. 19.

${ }^{70}$ Glauber Rocha, "O western - uma introdução ao estudo do gênero e do herói”, Mapa, Salvador (BA), ano 1, n. 1, 1957, p. 19.
} 
soteropolitano e, vez por outra, explorasse o western. Uma leitura atenta desses artigos pode estabelecer um paralelo entre eles e os que aqui merecem ser destacados, pois ampliam ou reforçam o que Glauber havia dito em Mapa. Destaco dois deles, a seguir.

Em 27 de outubro de 1957, no Diário de Notícias, de Salvador, sua crítica explora o filme western Rastros de ódio, de John Ford. O início do texto parece ser a parte de maior interesse. É quando o crítico delineia os aspectos do gênero. Intitulado "Notas à propósito de 'Rastros de ódio'”, o referido artigo restabelece o contato com o texto publicado em Mapa. Nele, Glauber volta a enumerar as razões pelas quais considera o gênero o modo mais original da representação americana no cinema: “A descoberta, a percepção e o domínio do tema com absoluta segurança de seus pormenores e sutilezas proporcionou a um punhado de cineastas a grande oportunidade de realizar um cinema de específicas e particulares consumações formais tanto no plano de ritmo e linguagem quanto no próprio aspecto da dramatográfica, no momento em que a intriga passa a obedecer àquela estrutura íntima, aquela linha do herói que vem de longe, vive e luta e vence o problema, e parte no fim para o mesmo 'não sei' de onde surgiu" 71 .

Em outro texto, ele não deixou de apontar as modificações e as novas modulações que o modelo ganhara com o tempo, ampliando sua visão sobre o teor original do gênero. No artigo "Burguês não é o herói que saca a pistola e enfrenta a morte no quente meio-dia", de 10-11 de janeiro de 1960, Glauber polemiza com um crítico português, Villaverde, e defende que o herói do filme western não é um personagem aburguesado. Segundo ele, o "novo western" não modificou seus temas, o personagem continua em seu aspecto original como antes; houve, sim, uma renovação estrutural, movida por necessidade econômica dentro do complexo industrial hollywoodiano. Daí sua consequência no surgimento de uma nova prática de western, sobretudo com modificações na montagem, cujo diretor Fred Zinnemann é o grande exemplo: "A super-estrutura consequente foi a nova forma. Coloque-se a montagem de 'High Noon' diante da montagem de John Ford. Enquanto neste está virgulando, apenas, em Fred Zinnermann [sic] o corte constrói o clima, como no CLIMAX, quando a cadeira, onde antes se sentara Frank Miller, é investida por um travelling que faz a tensão culminar. O que dentro da causa, dentro da origem econômica do

\footnotetext{
${ }^{71}$ Glauber Rocha, “Notas à propósito de 'Rastros de ódio”, Diário de Notícias, Salvador (BA), 27 out. 1957, p. 8.
} 
novo 'western' deve ter sofrido planejamento: mudar urgentemente a forma narrativa, adotar o choque, eliminar as fusões" 72 .

Não resta dúvida que sua atividade de crítico exercida em Salvador levou-o a pensar nos problemas e questões do filme western. Cabe levantar como essa sua recepção sobre um gênero e sobre outra cinematografia pode ter contribuído para uma configuração de uma visão própria e original da nossa realidade e o modo de representação dela.

Neste momento, abordo um artigo em que o crítico Ismail Xavier já disse ter sido talvez "o mais brilhante ensaio escrito na ocasião das primeiras discussões sobre Deus e o Diabo"73. Trata-se do artigo "Dialética da violência", de Luís Carlos Maciel, e que foi publicado no livro Deus e o Diabo na Terra do Sol, em 1965. Nele, o autor coloca lado a lado, o então recém-lançado filme de Glauber, Deus e o Diabo, e o modelo do western, com seus conflitos maniqueístas entre mocinhos e bandidos. Em ambos, o filme de Glauber e o modelo de lá, o eixo de discussão é a violência. No gênero americano contempla-se o que Maciel chamou de "metafísica da violência". A violência em Glauber, por outro lado, faria uma subversão desse tipo de violência. No caso do cineasta baiano, essa violência estaria ligada ao próprio tecido histórico, tendo sua existência relacionada com o próprio processo social de onde emerge. O termo utilizado por Maciel - "Dialética da violência” - pareceu ser bastante apropriado e afinado com o que estava em jogo na narração de Deus e o Diabo. Porque se a violência lá no modelo de western está muito mais ligada ao próprio fio de acontecimentos e encadeamento da narrativa, a violência em Deus e o Diabo é de outra ordem, sugere determinações históricas e reais ${ }^{74}$.

O crítico Ismail Xavier, anos mais tarde, alinhou-se a esses parâmetros para discorrer sobre a comunicação entre Deus e o Diabo e o filme western. Sua perspectiva registra o que é comum, mas principalmente aquilo que faz a diferença entre eles:

"Os deslocamentos em amplos espaços, a passagem rude e quase desértica, a perseguição implacável, a violência grupal e os duelos de feição cavalheiresca constituem matéria comum, o que não surpreende, tendo em vista a semelhança de origem que marca Deus e o Diabo e a mitologia western: o imaginário das lendas e baladas populares, em grande parte elaborado a partir de uma experiência

\footnotetext{
${ }^{72}$ Glauber Rocha, "Burguês não é o herói que saca a pistola e enfrenta a morte no quente meio-dia", Diário de Notícias, Salvador (BA), 10-11 jan. 1960, p. 3.

${ }^{73}$ Ismail Xavier, Sertão Mar, 1983, p. 121.

${ }^{74}$ Cf. Luís Carlos Maciel, "Dialética da violência”, in: Deus e o diabo na terra do sol, 1965, p. 208.
} 
social marcada pela presença do banditismo rural corolário às disputas de terra e à violência de jagunços e pistoleiros ligados aos grandes criadores de gado. Se existe, a partir dessas matrizes semelhantes, uma enorme distância entre a representação de Deus e o Diabo e a do gênero de Hollywood, um dos aspectos que me interessa nessa distância é a diferença de postura diante da história" ${ }^{35}$.

Os argumentos do crítico são elucidativos para a questão porque, ao mesmo tempo, que determinam um ponto de contato e origem de ambas narrativas, eles também refletem sobre as marcas distintivas entre elas. Em Deus e o Diabo não está em jogo, ao menos não é o seu principal aspecto, uma pedagogia do processo civilizatório, gerada sob a égide do duelo, sempre finalizado, renovado e repetido, entre o bem e o mal. Entre aquilo que é o modelo a ser seguido e modelo a ser rejeitado, numa postura moral presente em parte considerável do cinema americano e que mais tarde tornou-se também base da narrativa para a massificação da ficção seriada televisiva. Longe disso, o filme de Glauber inviabilizava tal procedimento, pois, afinal, propõe suas bases de representação da violência como algo próprio do personagem oprimido diante da violência simbólica invisível e, por vezes, institucionalizada ${ }^{76}$.

Que a violência da representação do western foi subvertida por Glauber isso não parece ser nenhuma novidade. Desde o lançamento do filme em meados dos anos 1960, essa questão vem sendo debatida e parece ser uma condução crítica em mais de um estudioso. Finalizando as reflexões sobre western e Glauber, gostaria de destacar que a reflexão sobre a veiculação da história do processo colonizador brasileiro maquinada por Glauber, em Deus e o Diabo e, em alguma medida, em $O$ dragão da maldade contra o santo guerreiro, faz parte de um processo que também se junta às suas reflexões sobre o western. No gênero americano, seus personagens vivem o processo de colonização pelo aspecto de sua vivência com os elementos da fronteira - a terra é desconhecida, o índio guerreiro e o bandido mexicano estão em conflito. Em Deus e o diabo, Glauber incorpora a temática da colonização a partir do sofrimento de seus personagens. Com eles, os conflitos pelas fronteiras não significam muita coisa. Daí se faz a diferença entre o que Glauber abordou e o que foi formalizado no modelo do western. No caso de Deus e o Diabo, o processo de colonização brasileiro é revisitado pela reflexão histórica, buscando sugerir quais foram as operações do passado, que mais tarde,

\footnotetext{
${ }^{75}$ Ismail Xavier, Sertão Mar, 1983, p. 122.

${ }^{76}$ Cf. Ismail Xavier, Sertão Mar, 1983, p. 123.
} 
transformaram-se na dicotomia entre a riqueza e a pobreza de um Brasil do interior. Fica evidente que o processo colonizador contemplado na narrativa glauberiana constitui acesso para a reflexão sobre as assimetrias sociais de dependência de nossa situação colonial vivida no passado.

Fechada esta pequena reflexão sobre a matéria do western, comento outro artigo de Glauber em Mapa.

Publicado em seu último número, em agosto de 1958, "Raices mexicanas de Benito Alazraki” é também um ensaio glauberiano de aderência a uma cinematografia estrangeira. Como o próprio título sugere, Glauber traça um perfil do cineasta mexicano Benito Alazraki. Mais uma vez, tal como havia feito com o western americano, ele focaliza uma cinematografia que estivesse refletindo sobre o processo de colonização da América. Nesse caso, a equação é modulada de modo distinto. Benito Alazraki e seu filme Raíces levam o empenho do jovem crítico, que não deixa de sublinhar ao seu leitor os relevos latinoamericanos da obra.

Seu artigo se inicia com uma tentativa de localizar no eixo historiográfico do cinema mexicano seu objeto. Benito Alazraki, cineasta mexicano nascido em 1921, retoma a linha temática do diretor Emilio Fernández e seu parceiro e fotógrafo Gabriel Figueroa, estes dois, os responsáveis por um conjunto de experiências históricas no cinema mexicano nos anos 1940. Segundo Glauber, a parceria Fernández / Figueroa, caracterizada pelo clima romântico em busca da nacionalidade e identidade nacional do mexicano, foi uma conjugação das mais felizes, porque permitiu a "descoberta poemática do índio na medida exata em que, entre nós, José Lins do Rego vislumbra os cangaceiros nordestinos"77. Esta descoberta, porém, foi apenas um estímulo temático para o trabalho de Benito. Distanciando-se de Fernández e Figueroa, este cineasta mexicano teve de penetrar por outros caminhos e nesse sentido, segundo palavras de Glauber, ele foi “despojando a linguagem em busca de um relato tão cru quanto sugestivo das raízes mais transcendentais da alma índia, pondo mesmo o social e o psicológico em função de tais elementos porventura peças de suporte da civilização francamente em progresso do México"78.

A obra em questão abordada por Glauber é o filme Raíces. Tendo a figura do índio como principal, em seu enfrentamento com o mundo tradicional de sua cultura e o

\footnotetext{
${ }^{77}$ Glauber Rocha, "Raices mexicanas de Benito Alazraki”, Mapa, Salvador (BA), ano 2, n. 3, ago. 1958, s/p.

${ }^{78}$ Glauber Rocha, "Raices mexicanas de Benito Alazraki”, Mapa, Salvador (BA), ano 2, n. 3, ago. 1958, s/p.
} 
modelo de civilização moderna de base europeia, o filme busca configurar uma visão das raízes e dos aspectos de formação do espírito mexicano. Formado por quatro episódios, com histórias que se relacionam pelo seu problema central, Raíces é considerado por Glauber como um precursor de um cinema latino-americano voltado e preocupado com os seus próprios problemas de formação e identidade nacional. Em termos simbólicos, Raíces tornou-se um filme representativo para a formação do jovem Glauber. Não se pode esquecer que foi com esse mesmo artigo sobre Alazraki e seu Raíces que Glauber abriu seu livro-síntese Revolução do cinema novo.

Ressaltem-se os aspectos do filme que interessaram ao jovem crítico. Seu artigo sublinha o painel antropológico criado por Benito para registrar a penetração devastadora do mundo branco sobre o mundo índio. Chamou a atenção de Glauber o modo como o cinema de Alazraki e de seus colaboradores abriram dois indicadores para o cinema latinoamericano: "a descoberta da terra pelos jovens realizadores dos países rurais latinos, principalmente Brasil e Argentina; outro, a cabal demonstração de que o neo-realismo, sob o ângulo duplo de produção e eleição temática, legou às cinematografias jovens lançadas na fogueira comercial, a possibilidade de triunfar dignamente"79. Complementares, esses dois aspectos funcionariam como pedra-fundamental das práticas cinematográficas que alcançariam um admirável número de redutos por toda América Latina. Glauber está voltado a valorizar as características de uma arte ligada ao regionalismo. Sob sua visão, observe-se que a terra documenta e registra como o principal elemento para a formulação de um regionalismo que não mais funciona como projeto exótico ao estrangeiro. Nessa nova formulação, a partir da valorização do elemento próprio e simbolicamente representado na terra de cada povo latino-americano, abre-se a possibilidade do trabalho em rigor de linguagem, que nos termos glauberianos alcançaria a "expressão nacional". Apenas esse trabalho de um "regionalismo cinematográfico" poderia possibilitar, segundo o jovem crítico, uma nova situação para cada cinematografia subdesenvolvida.

Aqui em nossas terras, Nelson Pereira dos Santos é tido por Glauber como o maior exemplo até então para se atingir o mesmo nível de realização e rigor de Alazraki e seu Raíces. Em certo sentido pioneiro, o trabalho de Nelson já enfrentava os problemas da terra e suas pesquisas formais já representavam um consistente diálogo com as realizações do neorealismo italiano; desse mesmo período, veja-se, como exemplos, os casos de seus filmes Rio

\footnotetext{
${ }^{79}$ Glauber Rocha, “Raices mexicanas de Benito Alazraki”, Mapa, Salvador (BA), ano 2, n. 3, ago. 1958, s/p.
} 
quarenta graus (1955) e Rio Zona Norte (1957). Mais à frente, tratarei da abordagem de Glauber em relação a Nelson.

Para o momento, saliente-se que, à época de escrita do artigo, Glauber, mesmo sem prévia experiência como realizador, notou a necessidade de se apontar os caminhos para a empreitada cinematográfica. Nesse sentido, em termos de estímulo ao jovem, a matriz elaborada por Alazraki foi vital para essas suas primeiras formulações. Raíces tornou-se o modelo de prática cinematográfica que aliava tópicos para a discussão dos problemas sociais e sua formalização moderna em termos de arte. Deve-se ainda somar a essa conta, que a recepção do filme de Alazraki chegava ao jovem crítico no mesmo momento em que ele também se renovava de leituras do regionalismo brasileiro, caso de José Lins do Rego. O cineasta mexicano mostrou que, entre vários caminhos, o cinema latino-americano realmente para ser reconhecido como arte moderna necessitava ampliar sua capacidade crítica de análise dos próprios movimentos históricos do continente e de seu processo de colonização. Talvez tendo em vista as experiências malogradas da Vera Cruz, Glauber partilhava de um discurso. Era necessário reverter o cinema latino-americano de sua ambição enquanto cópia das produções clássicas dos grandes estúdios americanos, para enfim criar uma nova perspectiva que acompanhasse o impulso de outras artes, tal como acontecia com a literatura produzida na época por aqui. Tanto sua visão sobre o western, revertendo a dimensão representativa da violência, como o propósito de ação oferecido por Alazraki, por meio de Raíces, eram fatores que o jovem soube apreender e acomodar em sua heterogênea formação. Com ambos, pode visualizar e formalizar uma forma de angariar a própria visão sobre nós mesmos. Eis talvez o aspecto que possa mais nos interessar.

\section{Na Universidade da Bahia, Ângulos}

Diferente de Mapa, que esteve ligada a um grupo formado a partir de afinidades eletivas, a revista Angulos é resultado das movimentações culturais de uma tradicional instituição baiana, a Faculdade de Direito da Universidade da Bahia. Em 1950, o aluno do terceiro ano do curso de Direito Adalmir da Cunha Miranda, aquele que se transformaria em crítico no jornal $O$ Estado de $S$. Paulo e que dialogaria por cartas com Glauber no período final daquela década, foi o responsável em formular a ideia inicial de uma revista ligada ao 
Centro Acadêmico Ruy Barbosa (CARB) que pudesse discutir os principais temas culturais daquele momento.

Com vida mais longa que Mapa, a revista tornou-se, durante toda a década de 1950 e parte dos anos 1960, bastante tradicional entre os estudantes daquela faculdade, sendo que as diretrizes de Angulos foram incorporadas à reformulação do estatuto do CARB, ocorrida no início de 1953. O artigo 54 desse documento retratava o papel da jovem revista e o seu primeiro item dava uma boa ideia dos propósitos e da estruturação de matérias e artigos contidos no corpo da publicação. A íntegra desse item expressava o seguinte: "Uma parte será dedicada à ciência jurídica, à filosofia, às ciências sociais em geral, e outra parte dedicada à literatura, às artes e à crítica, com a colaboração de estudantes, professores, escritores e artistas, locais, nacionais ou estrangeiros" ${ }^{\prime 80}$. A estrutura editorial da revista mostrou-se mais ou menos rígida e sempre esteve demarcada pela presença de um diretor e uma equipe de redatores, que muitas vezes também desempenhavam o papel de paginadores da publicação. A lista de nomes que passou pela revista como diretor ou redator e que mais tarde tornaramse escritor, ensaísta, crítico de jornal, poeta ou cineasta, seja na Bahia ou longe dela, é bastante ampla. Só para ficar em alguns nomes, cito: A. L. Machado Neto (redator em 1950 e diretor em 1951), Florisvaldo Mattos (redator em 1957), David Salles (redator em 1959), João Ubaldo Ribeiro (diretor em 1961), Wally Salomão (diretor em 1965-1966), além, é claro, de Glauber Rocha (redator em 1957 e 1958, além de paginador em 1957).

Em meio às escassas informações coletadas e sistematizadas que existem sobre a história de Ângulos, João Eurico Matta, que foi um dos estudantes da Faculdade de Direito em finais dos anos 1950 - portanto, contemporâneo de Glauber - e que assumiu o cargo de direção da publicação número 12, em 1957, escreveu um pequeno e valioso livro sobre as diversas fases da revista. É dele a interpretação que liga o trabalho editorial de Angulos ao trabalho de outros grupos que atuavam no circuito cultural da Bahia, caso dos participantes de Caderno da Bahia, este no início dos anos 1950, e dos participantes de Mapa, este no final dos anos 1950. E a esse estudo também devo a reprodução do primeiro editorial fundador da publicação e que foi escrito por Adalmir da Cunha Miranda e Eduardo Quintiliano Sobral da Fonseca. Por carregar o registro da diretriz de Angulos, que se seguiu na revista por grande parte de sua existência, este editorial pode ser considerado o meio termo entre a voz institucional, marca de uma ideia de representação dos estudantes de direito frente aos outros

\footnotetext{
${ }^{80}$ Apud João Eurico Matta, Ângulos: a vigência de uma revista universitária, 1987, p. 23.
} 
jovens baianos da sociedade, quando não uma marca de distinção daqueles frente aos demais, e a voz de seus organizadores que se encontravam motivados a estabelecer uma relação mais próxima entre os problemas da sociedade baiana e as formas de representação do objeto artístico, como já havia acontecido com a movimentação em torno da revista Caderno da Bahia. Das reproduções feitas desse texto-fundador no estudo de João Eurico Matta, destaco dois trechos que modulam bem esse aspecto que antes comentei:

\begin{abstract}
"Não nos opomos, sistematicamente, às gerações anteriores negando, de modo absurdo, as contribuições legítimas que deram ao espírito de seu tempo. Julgamos, mesmo, que é dever da juventude acolher essa contribuição com espírito crítico, ...contra todas as formas de domesticidade social e reacionarismo - ético, estético, filosófico e ideológico.

[...] Esta revista do CENTRO ACADÊMICO RUY BARBOSA é criada com o objetivo de ser útil aos estudantes da Faculdade de Direito da Universidade da Bahia. De restabelecer a existência de um diálogo...Não aceita uma orientação unilateral para o seu conteúdo. É ampla e não reflete a linha política de seus diretores, divergentes nesse ponto, mas que aderem à média geral das verdades deste editorial. Nesse sentido apresentará colaboração literária, artística e científica, portadora de um mínimo de méritos qualitativos que possa recomendar Angulos como uma verdadeira revista de cultura aos universitários e intelectuais do Brasil que a lerem" $"$.
\end{abstract}

A diversidade de assuntos e abordagens, a valorização dos jovens, sem, porém, destituir a importância da geração precedente, e o peso para as colaborações que reflitam sobre o campo cultural local são intervenções pregadas no início de Ângulos, que, em certa medida e com adaptações, repetir-se-iam mais tarde nos exemplares de Mapa e que continuariam a ser repisadas nas páginas da revista dos estudantes de direito em fases posteriores, caso de finais dos anos 1950, quando Glauber esteve à frente de ambas publicações. Este vai-e-vem de pessoas e ideias presentes no campo intelectual baiano daquele momento, que de fundo apresenta um problema, em nível teórico, sobre o nacionalismo na cultura brasileira nos anos 1950 e 1960, apenas reflete uma questão que poderia ser analisada em termos comparativos com o restante das manifestações da esquerda brasileira em todo o país no período.

\footnotetext{
${ }^{81}$ Adalmir da Cunha Miranda e Eduardo Quintiliano Sobral da Fonseca apud João Eurico Matta, Ângulos: a vigência de uma revista universitária, 1987, pp. 20-22.
} 
As impressões de Roberto Schwarz em um texto bastante polêmico, "Cultura e política, 1964-1969", publicado pela primeira vez na famosa revista francesa Les Temps Modernes, em 1970, tornam-se aqui válidas pela sua força de testemunho. A inflexão do ensaísta não se ateve apenas ao que ele previu ser um mecanismo social explicativo para aquele momento, Schwarz também se deixou contaminar pela própria experiência e pela própria percepção do clima cultural brasileiro de então.

Já que aqui lidamos com o final dos anos 1950, desse texto do ensaísta interessa o trecho em que ele busca esmiuçar as origens do colapso posterior à implantação da ditadura militar. Sua análise, assim, volta-se para o clima de antes de 1964, momento em que "o socialismo que se difundia no Brasil era forte em antiimperialismo e fraco na propaganda e organização da luta de classes" ${ }^{\$ 2}$. Interessa saber que para o crítico, por inúmeras razões, entre elas a estratégia conciliadora do Partido Comunista, havia se construído no Brasil "uma espécie desdentada e parlamentar de marxismo patriótico, um complexo combativo e de conciliação de classes, facilmente combinável com o populismo nacionalista então dominante" ${ } 83$.

Nesse horizonte, não é de surpreender que ideias em torno de reivindicação patriótica, ora combatendo o capital estrangeiro ou valorizando o aspecto local e sua representação regionalista, ganhem sua versão em uma revista de moços da Bahia ou qualquer outra parte do país. O combate à "domesticidade social e reacionarismo", termos presentes no primeiro editorial de Angulos, poderia ser traduzido à luz desses aspectos levantados por Roberto Schwarz como válido para si mesmo, ou seja, para sua vocação de uma esquerda que criou e difundiu matéria para si mesma. Era o florescimento do ideário esquerdista, no pré-golpe.

A seguir, gostaria de abordar os textos de Glauber Rocha no periódico. Agrupeios pelos seus tópicos de cinema e de literatura. No fundo, quando pensados sob o problema da abordagem da esquerda versus o espírito da época, tratam de uma mesma coisa. Portanto, possuem uma raiz comum.

\footnotetext{
${ }^{82}$ Roberto Schwarz, “Cultura e política, 1964-1969”, em Cultura e política, 2005, p. 10.

${ }^{83}$ Roberto Schwarz, “Cultura e política, 1964-1969”, em Cultura e política, 2005, p. 10.
} 


\section{Romance brasileiro 57-58}

Não é nenhuma novidade que Glauber, quase beirando os seus 20 anos, fosse um jovem bastante ligado aos problemas da nossa literatura. O texto sobre José Lins, publicado em Mapa, é um bom exemplo desse envolvimento, mesmo afetivo, com o objeto literário e suas raízes nacionais. O exemplo não é único. Suas cartas são também mais um registro dessa sua ligação e interesse. Entre uma linha e outra, Glauber sempre deixa um recado ao seu interlocutor em que pese a força da literatura como exemplo de fenômeno artístico empenhado na boa construção ficcional e sempre vinculado a nossa própria realidade social. Daí, seu caráter exemplar para o cinema em construção. Segundo sua convicção, exemplo que ultrapassava em longe o lugar-comum das adaptações literárias em cinema.

Em Angulos, como previra o seu projeto inicial, era bastante destacado o espaço dedicado ao fenômeno literário. Havia espaço tanto para a publicação de prosa e poesia de autores contemporâneos da Bahia e de fora dela, como para a publicação de avaliações críticas de livros, autores e estilos literários contemporâneos. Parte integrante da equipe editorial como redator e paginador, nos números 12 e 13, nos anos de 1957 e 1958, Glauber pôde desempenhar o papel de um dos críticos literários da publicação. Abordou a literatura em duas ocasiões: no artigo "Romance brasileiro - 57" e na resenha "Velas - Calasans Neto e Paulo Gil”.

Antes de comentar os respectivos textos, é preciso fazer algumas considerações, com base na linha editorial seguida por Ângulos, sobre um tema que é bastante recorrente em muitas revistas e discussões nos meios intelectuais brasileiros da época. Refiro-me ao que corriqueiramente foi chamado de nacionalismo na cultura. Ligado a esse conceito, está todo um referencial de valores. Compreendê-los, nos dias atuais, parece ponto importante como parte da tarefa de reflexão da experiência passada daqueles anos finais do decênio de 1950.

Tomar de exemplo os dois editoriais das tais revistas 12 e 13 de Angulos pode ser um começo interessante para pontuar certas ideias correntes entre aqueles jovens. O editorial intitulado "O 'homo ludens' brasileiro", publicado no exemplar 12 por João Eurico Matta, imprime à revista o papel de sua participação naquilo que se denominou como "um espírito novo", capaz, naquele momento, de "encarar e fortalecer uma civilização jovem que só agora 
começa a marchar para o oeste" ${ }^{\nexists 4}$. O significado de marchar para o oeste ganha em Ângulos a força de uma missão, da qual todos os jovens deveriam estar empenhados e preocupados com a vida pública nacional e o seu desenvolvimento. Com seu alerta, a revista demarcava uma posição inquieta e de bom grado com o discurso da esquerda do momento: "pretende trabalhar apenas, bem longe da dolorosa ociosidade e do 'panem et circensis' que seduzem o peso-morto [...]. É quanto nos basta: produzir, ainda que no setor intelectual. Pois não seremos nós os que farão falta à penosa indigência de técnicos, engenheiros, químicos, economistas e quejandos, que tanto dificulta ou atrasa o progresso do Brasil, país que infelizmente peca por excesso de bacharelismo jurídico" ${ }^{85}$. A constatação registrada no editorial da revista é a prova de suas preocupações. Era preciso, segundo eles, acelerar a marcha rumo ao desenvolvimento, em direção ao futuro entoado por tantos séculos e em momentos de frustradas convicções históricas. Não restava dúvida que o discurso de Ângulos estivesse contaminado por tudo que se agitava em vários pontos daquilo que poderíamos, grosso modo, chamar de elite do país. Veja-se um trecho do editorial em que se associam as mudanças em relação ao trabalho e à experiência livresca dos intelectuais:

\begin{abstract}
"Não nos desfaçamos da excessiva mentalidade livresca das nossas elites intelectuais, porque ela é indispensável no mundo de tão fértil cultura dos nossos dias: mas vamos associá-la ao dinamismo econômico e à pragmaticidade da tecnologia, de que carecemos para superar nossa Economia Sub-desenvolvida e de estagnação, as monoculturas regionais, os trustes estrangeiros e nacionais, os cartéis, os monopólios, os oligopólios; para implantar indústrias-chave e expandir as nossas estradas; para produzir nossa energia, nossa eletricidade e nosso petróleo e as grandes riquezas minerais desta terra. [...] Mas não confundam nacionalismo são e progressista com a forma politicamente retrógrada do nacionalismo protofascista ou criptofascista. Mantenhamos a democracia!"86.
\end{abstract}

Parece inevitável não trazer de novo o crítico Roberto Schwarz para o debate. Em seu texto, o mesmo citado de antes, sua leitura salienta as razões para a hegemonia cultural de esquerda, mesmo quando se decretou a ditadura de direita, em 1964. Como já havia ponderado antes, o crítico localiza que essa hegemonia cultural de esquerda tem suas origens

\footnotetext{
${ }^{84}$ João Eurico Matta, “O 'homo ludens’ brasileiro”, Angulos, Salvador (BA), ano VII, n. 12, dez. 1957, p. 1.

${ }^{85}$ João Eurico Matta, “O ‘homo ludens’ brasileiro”, Ângulos, Salvador (BA), ano VII, n. 12, dez. 1957, pp. 1-2.

${ }^{86}$ João Eurico Matta, “O ‘homo ludens’ brasileiro”, Angulos, Salvador (BA), ano VII, n. 12, dez. 1957, p. 2.
} 
no socialismo que se difundia no Brasil, antes de 1964. Sabendo que a forte presença antiimperialista pregada pelo Partido Comunista era seu aspecto combativo mais acentuado, como frisou o crítico, o mais interessante é notar que esse complexo ideológico deixava marcas em vários círculos, do Norte ao Sul do país. Angulos atesta isso. Nada mais justo a esse discurso do que combater o inimigo externo e alfinetar a direita latifundiária em um só golpe.

Em outro editorial, escrito por Nemesio Leal Andrade Salles na publicação número 13, sob o emblemático título "Panamericanismo apedrejado", o inimigo externo está ainda mais materializado do que nunca. Logo de início, o texto remete à conturbada visita do então vice-presidente americano Richard Nixon à América Latina, em 1958. Disse o editorial: "As pedradas sofridas pelo sr. Nixon em países sul-americanos mostraram claramente o ambiente de revolta popular dominante nas repúblicas visitadas, contra o jugo imperialista que as envolve" ${ }^{87}$. Os jovens de Angulos estabelecem o vínculo entre existência nacional e imperialismo. Para eles, é este último que nos sufoca. É este que impede o verdadeiro Brasil de amanhã, o "país onde tudo está para ser feito" ${ }^{88}$. Resta, ainda segundo o editorial, liberá-lo da velha mentalidade e revesti-lo da nova mentalidade, esta tida, por ela mesma, como vigilante.

Trouxe os dois textos editoriais com um fim, um propósito. Foi meu desejo expor as marcas de um discurso que sempre, salvo algumas exceções, esteve voltado e preocupado com o aspecto dito nacional. A “coisa brasileira” era a ocupação do momento para o jovem intelectual daqueles tempos. E continuou a ser assim por um bom tempo ainda. Veja-se a constatação a seguir. Em um ensaio inédito do escritor João Antônio, escrito entre os anos de 1967 e 1973, em que ele tenta esmiuçar o problema da literatura urbana brasileira, a tal "coisa brasileira" ainda é a preocupação do momento. Sua constatação é reflexo de mais de uma geração de ensaístas, escritores e artistas brasileiros: "Mas antes mesmo de se chegar a uma verificação do que existe entre nós em termos de literatura urbana realizada, é preciso explicar por que ela não tem aparecido com tantas facilidades. A verdade é que a coisa brasileira jamais apareceu, transfigurada em matéria estética e artística, com grandes facilidades. Essa busca, que não é tão jovem, vem ocupando, pelo menos, há mais de meio

\footnotetext{
${ }^{87}$ Nemesio Leal Andrade Salles, "Panamericanismo apedrejado", Ângulos, Salvador (BA), ano VIII, n. 13, jul. 1958 , p. 3.

${ }^{88}$ Nemesio Leal Andrade Salles, "Panamericanismo apedrejado", Angulos, Salvador (BA), ano VIII, n. 13, jul. 1958 , p. 4.
} 
século e de forma bem deliberada, estetas, artistas e escolas, que buscam um ideal comum de expressão aparentemente bastante simples: uma arte que apresente, em essência, o espírito que sintetiza todas as características brasileiras e seja apresentada em termos estéticos legitimamente brasileiros" ${ }^{\prime 9}$.

Intelectual de seu tempo, Glauber não foi diferente de seus contemporâneos. Quando escreveu sobre literatura no período fixou-se a partir de preocupações similares. Em seu artigo "Romance brasileiro - 57" ele revisita quatros romances do ano de 1957 e os julga a partir de suas contribuições à discussão do nacional. Outra vez, o artigo do jovem crítico inicia sublinhando a importância do regionalismo para o nosso romance. Para ele, a força do romance brasileiro - tão forte quanto lhe foi permitido pelo seu próprio povo, como aponta advém da "coerência e na continuidade que manteve com as realidades históricas, econômicas e sociais do Brasil" ${ }^{\prime 90}$.

Os seus exemplos?

Os mesmos de sempre: Graciliano Ramos, José Lins do Rego, Raquel de Queiroz, Jorge Amado e um Érico Veríssimo, este último quem sabe para variar um pouco seu repertório de Nordeste. Nessa encruzilhada - para não dizer cruzada - de escritores regionais, Glauber viu o que era talvez para si próprio o aspecto de maior relevo na tradição. Formulava-se, assim, seu parâmetro de valoração crítica. Fora disso, nada feito.

Embora sem seguir a cartilha à risca, registra-se, seu artigo em Angulos enuncia outros propósitos. Não queria - isso segundo suas palavras iniciais - prestar-se ao julgamento do modelo regional, mas, sim, fazer um exame daquilo que havia notado como o mais significativo daquele ano, em termos de publicações originais e de bom avanço para a linguagem do romance brasileiro contemporâneo de então. Desse modo, sua opção fica por conta da análise de dois romances urbanos - Loucos, poetas, amantes, de Geraldo Santos, e $O$ encontro marcado, de Fernando Sabino - e mais duas obras em que pesem os elementos regionais - A madona de cedro, de Antônio Callado, e Marcoré, de Antônio Olavo.

Apesar de ter elogiado certas soluções estéticas dos dois romances urbanos em questão, Glauber deixa claro pelas suas entrelinhas que essa tendência do nosso romance por ele denominada de romance citadino ou de metrópole - é uma contraposição em relação

\footnotetext{
${ }^{89}$ João Antônio, "Literatura urbana: isso existe?", s/ p. [material inédito, Arquivo João Antônio da Unesp de Assis; disponível também no site do Instituto Moreira Salles].

${ }^{90}$ Glauber Rocha, "Romance brasileiro - 57", Angulos, Salvador (BA), ano VII, n. 12, dez. 1957, p. 128.
} 
ao significado ainda do aspecto regional em nossa tradição romanesca moderna naquele momento. Sua posição se completa antes mesmo de ele iniciar a leitura crítica dos romances. É quando o jovem crítico baiano explicita seu entendimento sobre essa tendência, dizendo que, salvo raras exceções, esse tipo de romance "não atingiu uma constância qualitativa que o fixasse como uma característica cristalizada”. Glauber voltava-se para uma explicação do momento, portanto bastante valorizada entre boa parte de seus contemporâneos leitores e outros críticos locais: "a necessidade de alcançar uma consciência nacional forçou a fuga da metrópole geralmente mesclada $[\ldots]$ "..91 .

De uma só tacada, ele aliava dois termos: o nacional e o regional como partes de um mesmo complexo explicativo. Tratava-se talvez de um dilema por ele formulado: o nacional dependeu da representação regional e esta dependeu da força de criação de uma marca nacional. Essa posição claramente demarcada pelo jovem Glauber permite esboçar algumas interpretações em torno dela.

Do que resulta essa sua desconfiança para com o romance urbano e fidelidade à tradição regional brasileira moderna?

É preciso voltar lá atrás e notar os desdobramentos do nacionalismo gerado ainda pelo modernismo paulista de 1922. Significa apreender o impacto dessa difundida nacionalidade na geração que formou o romance social dos anos 1930, este de ampla influência para o jovem crítico baiano. João Antônio, no mesmo ensaio citado antes sobre o romance urbano, faz uma observação aguda sobre a geração desses romancistas e que ajuda a pensar a questão. Segundo o escritor paulista, é possível entender essa geração como propagadora de uma "reconstituição do tempo perdido". Ou seja, segundo suas observações, "quase todos os escritores dessa geração esmeraram-se na redação de livros, alguns volumosos, em que o gênero memória, fosse sob o disfarce de conto, romance ou novela, dominava conforme sua melhor conveniência" "92. Para o escritor de Abraço ao meu rancor, mesmo que muitos deles já estivessem estabelecidos em grandes cidades da região Sudeste brasileira, havia nesses prosadores uma disposição saudosista em estabelecer uma literatura a partir das próprias origens das pequenas cidades ou do campo, escrevendo em tom melancólico e nostálgico sobre uma infância perdida ou uma adolescência de lá atrás.

\footnotetext{
${ }^{91}$ Glauber Rocha, "Romance brasileiro - 57", Angulos, Salvador (BA), ano VII, n. 12, dez. 1957, p. 128.

${ }^{92}$ João Antônio, "Literatura urbana: isso existe?", s/ p. [material inédito, Arquivo João Antônio da Unesp de Assis; disponível também no site do Instituto Moreira Salles].
} 
Defensor de uma literatura urbana brasileira, a contraposição de João Antônio entre uma e outra opção é nítida: "em resumo, o saldo lamentável apresenta uma ficção nitidamente saudosista, que se desenrola à sombra das laranjeiras, nas tardes de sábado e domingo, entre uma cachacinha triste e um cigarrinho. Muita rememoração, bastante saudade e raiva surda daquilo tudo que a cidade grande representava ou poderia representar às suas vidas não exatamente pachorrentas, insossas ou acomodadas, mas apenas deslocadas do seu lugar próprio" ${ }^{93}$.

Longe de qualquer ingenuidade, é óbvio que João Antônio, escritor perspicaz que foi, sabia que o saldo era grande com o romance social de 1930. Basta notar os exemplos de Graciliano Ramos e José Lins do Rego, autores citados pelo escritor paulista. No fundo, tendo por base já toda a experiência da década de 1960 a seu favor, o que João Antônio quis mesmo estabelecer foi um mapa explicativo para o que pode ter acontecido em nome do nacionalismo brasileiro e o que, assim, poderia se apreender daquilo tudo para se pensar a dinâmica do romance de asfalto, como assim chamou e, em mais de uma situação, defendeu.

É diante disso, dessa pequena, embora contundente, observação do escritor paulista que se pode pensar o ponto de vista criado pelo jovem crítico Glauber Rocha, em suas posições defendidas no artigo de Angulos. A fonte da qual o crítico baiano bebia de literatura era, sem dúvida, formada pelo que havia de mais regional. Daí, também se explica sua fascinação pelo escritor de Menino de engenho. E não uma fascinação qualquer, mas criada, até certo ponto, a partir dessa observação e aderência saudosista a um passado melancólico e de base nacionalista. Por certo, seus interesses eram baseados nessa dinâmica do que é nacional e, portanto, regional. Lembre-se que é da mesma época, de 1958, sua viagem de trem, junto com o amigo Joca, para conhecer o mestre da cerâmica Vitalino ${ }^{94}$.

Não podia ser diferente, Glauber deixava tudo contaminar-se pelo regionalismo. Quando via asfalto, arranha-céu, automóvel, logo os contrapunha, em termos de paisagem, ao campo, ao engenho, ao carro de boi. Esse ponto de vista torna-se mais nítido em sua análise de Loucos, poetas, amantes, do estreante Geraldo Santos, no artigo de Angulos. Três problemas são colocados por ele em termos críticos para a realização plena desse romance e que são os seguintes: “a) a cidade, como técnica de captá-la geral e particularmente; b) a

\footnotetext{
${ }^{93}$ João Antônio, "Literatura urbana: isso existe?", s/ p. [material inédito, Arquivo João Antônio da Unesp de Assis; disponível também no site do Instituto Moreira Salles].

${ }^{94}$ Cf. João Carlos Teixeira Gomes, Glauber Rocha, esse vulcão, 1997, pp. 121-131.
} 
trama ou colocar uma geração intelectualizada, tomada pela angústia de após-guerra. O não saber que caminho ou futuro. Procurar situar este isolado grupo em uma metrópole e daí encetar uma expedição devastadora para completa generalização; partir deste particular para um geral, foi o terceiro problema de Geraldo Santos que surgiu como lógica solução para os dois antecedentes. Até onde o romancista resolveu, até que ponto realizou os intentos?"95.

Ao fazer a pergunta, a resposta já estava dada. Tudo o que o jovem crítico levanta de problemas deve-se à particularidade da relação paisagem urbana e personagens, que no caso por ele avaliado - o de Geraldo Santos - funcionou em termos dentro da fatura do romance. Explico melhor. Loucos, poetas, amantes constrói seu enredo a partir da história de alguns personagens que se ambientam na cidade de São Paulo, entre eles: André, o jovem pintor, personagem central na narrativa; sua irmã Aloysia; Vínius e Jim Madeira, seus amigos mais pobres e também ligados à arte; e Estefânia, personagem que André conhece em um encontro casual.

Ambientado em 1946, a primeira parte do romance se prende aos dramas psicológicos dessa geração de jovens - André e seus amigos que vivenciam os projetos intelectuais na casa deste personagem central, também denominada pelos seus frequentadores de "o covil". Na segunda parte, o enredo encontra sua reviravolta e de drama de geração passa ao problema de amor. No que Glauber chamou de "coincidência demasiadamente 'cinematográfica', dado seu aspecto convencionalíssimo de construção, André tem um encontro casual de amor com a personagem Estefânia. Para Glauber, o problema maior do romance começa na medida em que o personagem André, já longe de sua relação com Estefânia, inicia, no que seria uma terceira parte, sua investigação pelos meandros da cidade em busca do seu pai sequestrado. Ali se delineia um desenho da cidade, pela sua miséria e opressão de metrópole. Segundo o crítico de Angulos, tal construção leva a uma incompatibilidade da relação entre paisagem urbana e o aspecto psicológico de seu personagem retratado:

"O draminha piegas do covil sofre a interrupção forte e trágica de um mapa humano-social de São Paulo. Ao passo que André, de pintor e de amante transformado em detetive, desenvolve sua caçada, o autor revela na melhor técnica cinematográfica trechos da vida metropolitana. Surgem em rápidos 'cortes'

\footnotetext{
${ }^{95}$ Glauber Rocha, “Romance brasileiro - 57”, Angulos, ano VII, n. 12, dez. 1957, p. 130.
} 
diversos trechos desta vida. Tecnicamente esta solução, embora denotando uma certa influência da moderna novela-roteiro americana (Paulo Dantas apontou John dos Passos), é perfeita; psicologicamente talvez falha porque os reflexos de tais vivências em André não se processem de maneira a que ele, - o artista - as cultive. Passa pela noite como um boêmio; menos, porque pouco participa" ${ }^{\text {96. }}$.

Essa tal incompatibilidade levantada por ele também deve ser entendida como um modo dele recusar aquilo que não demarca com tintas fortes o aspecto nacional, reapresentando o problema social em sua denúncia. Por esse ponto de vista, André não se processava dentro daquele ambiente marginal e, portanto, não trazia consigo o aspecto da denúncia. Diante desse aspecto, Glauber enxergava o romance urbano menos afeito à sua causa do que o romance social e regional. Isso não quer dizer que esse ponto de vista o impediria de notar seus bons exemplos de romance urbano. Foi o caso de Fernando Sabino, com $O$ encontro marcado. Sua primeira observação é que o autor "realiza o frustro em Geraldo Santos"97. Em outras palavras, o livro de Sabino, segundo Glauber, cumpriu aquilo que o livro de Geraldo Santos buscava cumprir: fazer um fino retrato de uma geração intelectual, marcada pelos reflexos de 1945. Está aí sua empatia com o livro, pois, embora exemplo de romance urbano, ele cumpre uma outra função. Embora a retrate, não se fixa na paisagem urbana sem dela extrair seu princípio de denúncia ou argumentação filosófica ou sociológica, mas se empenha em entrever no aspecto psicológico de seu personagem Eduardo Marciano - um dilema presente em tantos outros jovens, como era, por certo, o do próprio jovem crítico: "Eduardo Marciano é mais que o autor autobiografado, elastece-se e atinge um plano simbólico de quantos passaram a ativamente exercer literatura e arte no Brasil de após-guerra. O jovem intelectual na vertigem da cidade, a imaturidade, a frustração consequente e a sede de se realizar"98.

Se Antonio Callado, com $A$ madona de cedro, trouxe um outro tipo de prosa para sua percepção, abrindo uma nova geografia para o nosso romance - construído nem na metrópole, nem no campo -, o exemplo maior, porém, de boa execução naquele ano, foi mesmo a obra Marcoré, de Antonio Olavo Pereira. A razão da escolha para o crítico afinavase com os seus parâmetros de prosa de ficção sóbria, colada ao melhor estilo regional de um

\footnotetext{
${ }^{96}$ Glauber Rocha, “Romance brasileiro - 57”, Angulos, Salvador (BA), ano VII, n. 12, dez. 1957, p. 131.

${ }_{97}^{97}$ Glauber Rocha, "Romance brasileiro - 57”, Ângulos, Salvador (BA), ano VII, n. 12, dez. 1957, p. 132.

${ }^{98}$ Glauber Rocha, "Romance brasileiro - 57”, Angulos, Salvador (BA), ano VII, n. 12, dez. 1957, p. 132.
} 
dos nossos grandes escritores daqueles tempos, pois, afinal, Antonio Olavo Pereira era, segundo suas palavras, “o mais exato e perfeito rebento da novelística Graciliano Ramos. Discípulo pelo intimismo amargo e maduro e pela enxutez do estilo, limpo, despido do adjetivo"99.

Os elogios ao romance de Antonio Olavo Pereira não pararam por aí. Julgado por Glauber, Marcoré assumiu um papel-emblema: foi considerado por ele como um clássico de nossa literatura contemporânea. Tratava-se de um novo emblema naquele momento, por conta de ser um romance que confundia bem “'ficção à confissão' (feliz achado de Antonio Candido em relação a Graciliano Ramos)”. Para Glauber, tudo lembrava aspectos de Graciliano: "fugindo do campo mas permanecendo no interior, a geografia de Marcoré situase em pequena e característica cidadezinha provinciana do Brasil, ambiência a lembrar o livro início de Graciliano, Caetés" ${ }^{100}$.

A consciência do romancista em denunciar os problemas do homem rural chama a atenção do jovem crítico. Com base na perspectiva regional, é válido para Glauber, naquele momento, uma narrativa que provoque o encontro entre homem e terra, em seus aspectos mais tensos e polêmicos. Mais uma vez, Marcorée seu autor são bons exemplos:

\begin{abstract}
"Antonio Olavo como um romancista sobretudo consciente e necessitado de uma trabalhada funcionalidade formal ao tema do homem torturado em parte por um determinismo da paisagem (onde o regionalismo funciona) em parte por uma complexa dissolução física (a morte de Honorata; a morte de 'seu' Camilo; a morte de Silvia) e humana (o chocante e amargo rompimento de 'Marcoré' com o pai), - necessitado disto, pois, Antonio Olavo busca em Graciliano - mestre inatacável da espécie - as suas melhores lições e os seus mais sólidos fundamentos" ${ }^{\prime 101}$.
\end{abstract}

Em julho de 1958, no periódico seguinte de Ângulos, o de número 13, Glauber publica o pequeno artigo "Velas. Calasans Neto e Paulo Gil", em estilo de resenha, e estabelece, de certa forma, uma outra ordem de problemas ao abordar o objeto literário. Seu propósito é anunciar a publicação artesanal, em exemplar luxuoso e impresso à mão, do livro de poemas de Paulo Gil com gravuras de Calasans Neto, ambos amigos de Glauber. Foge-se à

\footnotetext{
${ }^{99}$ Glauber Rocha, “Romance brasileiro - 57”, Ângulos, Salvador (BA), ano VII, n. 12, dez. 1957, p. 134.

${ }^{100}$ Glauber Rocha, “Romance brasileiro - 57”, Ângulos, Salvador (BA), ano VII, n. 12, dez. 1957, p. 135.

${ }^{101}$ Glauber Rocha, "Romance brasileiro - 57", Angulos, Salvador (BA), ano VII, n. 12, dez. 1957, p. 135.
} 
preocupação mais ampla de mapeamento do romance brasileiro contemporâneo e se infiltra na defesa local de certos romancistas e suas obras. Mais do que a resenha de um jovem autor sobre a obra de outros jovens autores locais, sua abordagem registra uma componente importante para se compreender o significado do gesto glauberiano. Para sua compreensão é preciso entender o cruzamento da amizade juvenil de Glauber - momento em que formulava sua rede de relações - e as formas de divulgação que os jovens autores encontravam dentro das amarras da difusão mais tradicional do circuito artístico baiano.

Essa resenha de Glauber não se restringe a falar de autores e obras. O pano de fundo é a obra dos dois autores-editores, mas o crítico baiano não desperdiça a oportunidade para salientar os feitos de uma jovem geração em ascensão. Ainda que lentas, são transformações que aos poucos abrem o espaço necessário para esses novos moços na tradicional Salvador. Tudo se conecta para configurar esse propício espaço. É o livro, como artefato artesanal, que surge da boa vontade de alguns: "Linotipo na casa gráfica de Zitelman e impressão na prensa de gravura da escola de Belas Artes. Lançamento na galeria Domus”"102. É a nova geração, que com suas ações, vai aos poucos angariando, na perspectiva local, o apoio de intelectuais mais bem estabelecidos: "a melhor repercussão que anima os dois artistas editores à nova tirada: um poema de Carvalho Filho; outro de Godofredo Filho"103. É a cobrança de apoios que se faz pública e sonora: "Há a promessa de que o dr. Mendonça Filho monte mesmo uma prensa manual e providencie uma caixa de tipos. É tempo das artes gráficas na Bahia" ${ }^{104}$.

Na perspectiva de Glauber, os autores resenhados são, na verdade, o resultado de uma ação mais profunda que ocasionou a mudança dos ânimos culturais da cidade. Veja-se como ele faz a ligação da publicação do livro com o restante do que se transformava na cidade, deixando o recado para os não-aliados:

“Convém que se olhe - melhor, que a Universidade lance uma carinhosa olhada
sobre Calazans e Paulo Gil. Editora Macunaíma, afinal é a terceira coisa graúda -
sem o mínimo cabotinismo - que se faz por aqui depois de 'Jogralesca' e 'Mapa'. É

${ }^{102}$ Glauber Rocha, "Velas. Calasans Neto e Paulo Gil", Angulos, Salvador (BA), ano VIII , n. 13, jul. 1958, p. 144 .

${ }^{103}$ Glauber Rocha, "Velas. Calasans Neto e Paulo Gil", Angulos, Salvador (BA), ano VIII , n. 13, jul. 1958, p. 144 .

${ }^{104}$ Glauber Rocha, "Velas. Calasans Neto e Paulo Gil", Angulos, Salvador (BA), ano VIII , n. 13, jul. 1958, p. 144. 
uma associação complexa que muita gente não sabe como vive de mistérios. Mas o certo é que a despeito da sabotagem oral de muito descrente a máquina está engatilhada para outros maiores sustos na província. Apenas o padrinho que falta mas não tarda" ${ }^{105}$.

Glauber se arma para utilizar e divulgar formas análogas de pensamento artístico e intelectual à sua maneira de ver as coisas. Se Calasans Neto, como artista das gravuras, e Paulo Gil, como poeta, são autênticos e depurados, espécie de representantes de uma arte da "universalidade através do particular daqui bahiano", é porque o crítico quer fazer crer que esses e outros artistas dessa nova geração, incluindo a si mesmo, são a via mais profícua da boa representação da arte nacional que demarca o universo da Bahia.

\section{Da cinestética ao filme experimental}

Sabendo que Ângulos foi um espaço heterogêneo de divulgação de uma variedade de manifestações artísticas, é evidente que o cinema também estaria contemplado. A Bahia, para ser preciso Salvador de finais dos anos 1950, vivia o cinema pela sua crítica de jornais e revistas, pelo cineclube encabeçado por Walter da Silveira - por sinal, lugar onde a geração de Glauber se formou -, e pelas experiências de produção mais constantes que começavam a aparecer no cenário baiano ${ }^{106}$.

Como vimos em Mapa, Glauber publica dois textos sobre a arte cinematográfica, deixando à tona uma mistura, bastante nuançada, que guardava a aceitação de duas formas tão distintas em termos de modelos cinematográficos: uma pela via do western americano, consagrando um aspecto de originalidade, e outra pela abordagem do nacionalismo de um cineasta mexicano, estimulando uma prática de luta nacional pelo caminho da arte cinematográfica. Como não poderia ser diferente, dado que se tratam de textos contemporâneos e formulados sob o mesmo estímulo juvenil, os artigos de cinema em Ângulos ainda percorrem solto e com liberdade a arte cinematográfica. Os comentários a seguir estão baseados em dois textos publicados por Glauber - "De cinestética", de julho de

\footnotetext{
${ }^{105}$ Glauber Rocha, "Velas. Calasans Neto e Paulo Gil", Angulos, Salvador (BA), ano VIII , n. 13, jul. 1958, p. 144.

${ }^{106}$ Cf. Walter da Silveira, A história do cinema visto da província, 1978.
} 
1958, e "Filme experimental: um tempo fora do tempo", de maio de 1959. Em ambos, os olhos do jovem crítico para o cinema voltam-se para os problemas de ordem formal. Vejamos como isso se dá.

Publicado em Ângulos 13, "De cinestética” pode ser lido como a materialização das preocupações teóricas do jovem Glauber Rocha. É a síntese de seu empenho em esmiuçar a linguagem cinematográfica e suas ligações com as outras artes. Encarando o aspecto singular dessa linguagem, Glauber lança o cinema como forma de conhecimento que se amplia em espectro variado, podendo ser analisado e refletido em decomposições de ordem histórica, psicológica e outra, que ele denomina cinestética e onde concentra seus maiores esforços analíticos.

Não resta dúvida que as formulações teóricas do jovem Glauber receberam estímulos de diferentes fontes e autores. Não é o caso de definir com precisão todas essas referências. Até porque elas se misturam, transformam-se, e no tecido textual ganham outra dimensão, muitas vezes dando origem, sob novos aspectos e tonalidades, a uma forma distinta do que originalmente foi um dia. O texto de Ângulos, porém, sinaliza o que pode ser um caso de acomodação ou transformação de ideias originadas de outro texto. A possibilidade é grande, embora não certa, de que o livro Elementos de cinestética, lançado em 1957, de autoria do atuante padre Guido Logger, possa ter sido uma dessas leituras do crítico. A difusão do livro de Logger tornou-se ampla e irrestrita em certos círculos, dada a força com que a igreja católica atuava naquele momento na organização de cineclubes e cursos de cinema ao redor de todo o país ${ }^{107}$. Deve-se registrar que o estímulo da igreja católica para a formação de espectadores de cinema é de longa data. Em 1953, a Confederação Nacional dos Bispos do Brasil (CNBB) já havia criado o Centro de Orientação Cinematográfica, cuja primeira presidência foi assumida por Logger. Voltando ao caso de Glauber. Frequentador de clubes de cinema, não é de se estranhar que um exemplar do livro possa ter caído em suas mãos e assim ter sido objeto do seu interesse.

$\mathrm{Na}$ fórmula "PROBLEMA CINESTÉTICO: Antinomia entre cinema como síntese das artes versus cinema como arte autônoma; sub-problema: cinema e a polêmica entre forma e conteúdo" Glauber equaciona sua abordagem. Fixa-se por alguns caminhos.

\footnotetext{
${ }^{107}$ Cf. Paulo Emílio Salles Gomes, “Catolicismo e cinema”, em Crítica de cinema no Suplemento Literário (V. 1), 1981, pp. 71-74 [O Estado de S. Paulo, 26 jan. 1957]; André Gatti, "Cineclube”, em Enciclopédia do cinema..., 1997, pp. 128-130.
} 
Qual o alcance do cinema? A que arte ele se relaciona? E o cineasta, é tão autônomo como o escritor? E o problema da forma na arte do cinema? Como o aspecto formal na linguagem cinematográfica guarda relação com todos esses problemas?

Glauber sabe que o específico fílmico, aquilo que distingue a arte do cinema das demais artes, passa pela compreensão dessa relação entre artes. Entre todas as artes que o cinema abriga em sua formação, o jovem crítico salienta a importância da literatura como tributária do projeto de realização de um cineasta. Segundo ele, na literatura está "a base primeira do filme, sua matéria-prima, elemento sobre o qual o cineasta exerce a sua função específica e extrai o ritmo que confere dignidade ao movimento da imagem, que a faz esteticamente realizada ou não"108. Se o cinema não se sujeita às outras manifestações artísticas a ponto de tornar-se uma síntese delas todas, por outro lado, ele também não pode ser considerado um núcleo autônomo, ato de pura criação. O trabalho do cineasta, como artista, distingue-se do escritor, do escultor, do pintor, pelo seu contato distinto com o real. Sua dependência é outra, a imagem pura, captada do real, guarda em si o seu aspecto ontológico, ela existe e o modo como depende da imaginação se distingue do modo como ocorre a construção da imagem no poema ou no romance, por exemplo. Em termos comparativos, para o cineasta e para a arte do cinema "a realidade seria mais vital em seu estado de crueza não estilizada, do que mesmo já em captação do teatro, do conto ou do romance, aspecto que em geral se apresenta ao cineasta" ${ }^{109}$.

Sem a experiência da realização em cinema, Glauber ainda é observador. Mas não um observador qualquer. Há que se reconhecer, já naquele momento, suas pretensões em definir, mesmo que por um esboço juvenil, as possibilidades do campo de atuação para o que poderia ser a atividade futura. É nesse contexto que ele delineia as primeiras linhas sobre a relação entre cinema e arte poética. Se ele via um grande e proveitoso encontro entre aquilo que o poema oferecia em termos de reflexão dos problemas de estilo na composição de qualquer forma artística, ele também notava, a partir de sua experiência de crítico, que cineastas estavam quase nunca afeitos ao desenvolvimento de uma poética no cinema. Mesmo seus melhores exemplos de cineastas ainda estavam "submissos a uma gramática acadêmica" ${ }^{110}$, deixando ainda o campo da responsabilidade criadora para o argumentista,

\footnotetext{
${ }^{108}$ Glauber Rocha, "De cinestética”, Ângulos, Salvador (BA), ano VIII , n. 13, jul. 1958, pp. 115-116.

${ }^{109}$ Glauber Rocha, "De cinestética”, Ângulos, Salvador (BA), ano VIII , n. 13, jul. 1958, p. 116.

${ }^{110}$ Glauber Rocha, "De cinestética”, Ângulos, Salvador (BA), ano VIII , n. 13, jul. 1958, p. 116.
} 
que, sob seu olhar, "não é senão a matéria bruta sobre a qual o cineasta desenvolve sua criação artística" ${ }^{\prime 11}$.

A relação entre poesia e arte cinematográfica marca o filão a ser explorado pelo jovem crítico. Glauber constrói sua argumentação apoiada em uma tradição cujo ponto de origem parece ser o que se configurou, em termos de condições sociais, com o modernismo ainda dos anos 1920. Esse é o seu horizonte: aquilo que se depurou de ideário modernista. Mesmo que a tônica ainda seja a construção de uma brasilidade, vale o novo, o arrojo na construção formal da linguagem artística. E para tal empreitada, no caso do cinema, nada parece se ajustar melhor do que procurar o estímulo argumentativo na linhagem de bons poetas. Juntou uma ideia aqui, outra acolá; um poeta aqui, um teórico acolá. Assim, Glauber procurou definir um ponto de contato entre aquilo que era a nossa maior e mais consagrada tradição, a literatura, e a nossa mais jovem tradição artística, o cinema. Leitor do cineasta e teórico russo Sergei Eisenstein, Glauber notava relações entre a teoria fílmica deste e a “psicologia da composição” de João Cabral de Melo Neto. No caso do cinema, o teórico russo considerava o plano isolado do filme, o fotograma, sem nenhuma funcionalidade, similar à palavra em seu estado de dicionário. Por conseguinte, caberia ao cineasta o ato de ensaiar a transformação do dado do real em realidade de criação e interpretação na montagem. Em outros termos, o dado real em si, impresso no simples fotograma, em nada tinha de arte. Era papel do cineasta, entenda-se autor, dar vida ao fotograma. Na poesia a mesma reação haveria de ter o poeta diante da página em branco, da folha em branco. Glauber recorre às palavras do poeta de $O$ cão sem plumas para precisar melhor a metáfora. É dessa forma que a página vazia "prescreve o sonho" desse poeta e o “incita o verso nítido e preciso”. São nessas páginas sem palavras que "pode teu sal virar cinza, pode o limão virar pedra, o sol da pele, o trigo do corpo virar cinza" ${ }^{112}$. O exemplo não é o único de suas explicações das relações entre as duas artes.

Veja-se outro ilustrativo aspecto do corte no cinema e sua correspondência na literatura:

"O corte em cinema encontra um correspondente no corte poético, tanto nas analogias quanto nas simbologias ou estabelecimento de imagens; também as

\footnotetext{
${ }^{111}$ Glauber Rocha, "De cinestética”, Ângulos, Salvador (BA), ano VIII , n. 13, jul. 1958, p. 116.

112 Apud Glauber Rocha, "De cinestética”, Angulos, Salvador (BA), ano VIII, n. 13, jul. 1958, p. 118.
} 
fusões, equivalendo às sugestões superpostas, ou o verso largo, chamado bíblico, de Augusto Frederico Schmidt ou Claudel - encontraria sua identificação cinematográfica na grande panorâmica, a de John Ford, por exemplo, nos filmes 'western'. Nos dois casos citados, poderíamos exemplificar o primeiro com este momento de 'A Balada do Morto Vivo'. '...Em frente da balsa para / A lancha com o corpo em cima / (corta) Os caboclos se descobrem / (corta) Lunalva se aproxima / (corta) Levanta o pano (corta) olha a cara / (corta) e dá um medonho grito / ...' -, o segundo com outro poema do mesmo Vinicius de Moraes, 'A Manhã do Morto', que possui aliás uma disposição gráfica de roteiro. Ei-lo: 'situação cenário': O poeta, na noite de 25 de fevereiro de 1945, sonha que vários amigos seus perderam a vida num desastre de avião, em meio a uma inexplicável viagem para S. Paulo; 'desenvolvimento da seqüência': Noite da Angústia; que sonho / que debater-se, que treva / (fusão)...é um grande avião / (fusão violenta) que leva amigos meus no seu bojo... / (fusão mais rápida, precipitada) ...depois a horrível notícia / (superposição precipitadíssima, letreiros surgindo do fundo até o primeiro plano): MÁRIO DE ANDRADE MORREU. Note-se, pois, nos dois exemplos citados, no primeiro, o corte, no segundo, a fusão, pontuações que o cinema herdou da poesia e desenvolveu até onde os cineastas criadores puderam atingir. Escolhemos Vinicius de Moraes para exemplo, por ser ele, dentre os nossos poetas, um estudioso do cinema, tendo, por isso, consciência absoluta dos recursos cinematográficos que aplica em sua poesia" ${ }^{\prime 13}$.

O ensaísta Ismail Xavier, ao escrever o prefácio da recente edição de Revisão crítica do cinema brasileiro, salientou a importância de se compreender a questão da poesia no cinema brasileiro moderno. O exemplo é válido para Glauber, embora também pudesse ser pensado para o restante do nosso Cinema Novo. Está sob o horizonte do ensaio de Ismail o método crítico da "política de autores", de inspiração francesa, pregado por Glauber Rocha, e como isso se transformou num modelo de crítica de arte para se pensar o aspecto da brasilidade e o estilo, este incorporado via tradição modernista dos anos 1920. Nas palavras do ensaísta:

“Os valores essenciais da 'política dos autores', bem como as questões que envolvem a relação mais livre com a técnica (temas do cinema moderno em geral), ganham aqui uma feição local que tem referência no plano literário, terreno em que Glauber toma o partido da dicção poética modernista contra a pompa e a retórica. Não por acaso, ele minimiza a dimensão narrativa, horizontal (mais

\footnotetext{
${ }^{113}$ Glauber Rocha, "De cinestética", Ângulos, Salvador (BA), ano VIII , n. 13, jul. 1958, p. 117.
} 
associada, então, à fatura do roteiro) e prefere o momento da instauração do poético: o eixo vertical da imagem, o fragmento que concentra a gema, a verdade do autor"114.

Quase um ano depois do texto "De cinestética", é publicado o artigo "Filme experimental: um tempo fora do tempo", estampado em Angulos 14. As ideias contidas no primeiro artigo prolongam-se, em outra roupagem, nesse novo texto. Mais uma vez, vale para Glauber o cinema não pela sua intriga e roteiro em molde clássico ou seu sucesso econômico, mas sua versão de arte preocupada com os avanços de linguagem. Glauber se faz valer de uma ideia muito cara que foi construída no seio da tradição literária ocidental há um bom tempo: a contraposição arte pura e mundo econômico. Nessa concepção, o homem da arte, desde que faça a opção pela arte pura, é aquele quem rejeita o mundo ordinário (e dos negócios) e o incompatibiliza com seu próprio universo de arte. O acesso ao mundo da arte pura é a rejeição do mundo mercenário, para utilizar um termo frequentado por Pierre Bourdieu.

Como única viabilidade para o cinema, o jovem crítico adere à forma de representação do amor à arte pura. A perspectiva adotada cria contraposições. Filme experimental significa o oposto de filme industrial na perspectiva americana dos grandes estúdios. Se o tempo no cinema comercial desses grandes estúdios é a pontuação e demarcação linear de um processo lógico do próprio enredo fílmico, no cinema experimental o tempo ganha outros arranjos. Este último, em suas palavras, trata da construção do intemporal no cinema. Sua inspiração é a novelística de William Faulkner. Guardadas as características entre uma e outra arte, o "intemporal como fundamento" é a realização daquilo que o escritor americano havia ensaiado em suas narrativas. $O$ crítico enxerga na subversão sintática do escritor, que, sem concessões, instalava uma nova marcação temporal dentro da estrutura da própria obra, um estímulo para tratar o cinema e sua possibilidade de realizar-se como arte pura.

Talvez seja mais do que isso. Muito jovem, Glauber está desafiado a esboçar um rascunho sobre o papel do artista moderno. Não é à toa que a inversão apontada por ele destaca um problema quase comum para os caminhos da literatura e os caminhos do cinema: “à medida que o romance moderno filiado à linha tradicional da narrativa em reta, procura 'renovar-se' introduzindo clima e ação 'cinematográficos', o cinema narrativo cada vez mais

\footnotetext{
${ }^{114}$ Ismail Xavier, "Prefácio”, em Glauber Rocha, Revisão crítica do cinema brasileiro, 2003, pp. 19-20.
} 
se prende a esse tipo de literatura"115. O agonismo de ambas as artes retratado por Glauber, buscando-se apoiar uma na outra, teria, em sua perspectiva, uma solução viável. Concentrarse no aspecto expressivo que está contido em cada um - na literatura, a palavra e a sintaxe, no cinema, o enquadramento e a montagem - e a partir deles renovar as dinâmicas de expressão de ambos, este parece ser o caminho de argumentação adotado. É o caminho que decreta o fim do cinema de histórias e intrigas como base. É a defesa da arte pura para o cinema.

Em linha distinta da perspectiva industrial dos grandes estúdios, para essa desafiadora missão, Glauber via o filme experimental como único capaz de fazer tal busca. Uma busca de um 'tempo-espaço, fora do 'tempo-espaço' corroído de hoje, uma absoluta humildade, uma rejeição total ao fruto em sua geração, uma sacerdotal pesquisa que pode mesmo não chegar a resultados por anos e anos"116. Uma busca que reconstitui seu caráter mais emblemático: a defesa do amor pela arte, ainda que um amor louco diante da normatização do mundo moderno, como mais uma vez diria o sociólogo francês Bourdieu. As palavras finais de Glauber são a bandeira de um empenho que se tornaria cada vez mais presente dali em diante na difusão de sua ideias. É o empenho do que é o potencial expressivo do objeto artístico e sua provável mistura ao ensaio sobre a prática do artista moderno:

“[...] O cinema é uma arte nova. E sua crise é a mais angustiante de todas. Porque se a literatura agoniza como arte narrativa, ela tem de reconhecer no fundo que sempre foi arte narrativa. Mas o cinema não é. Transformou-se por um desvio da imaginação humana e cada vez mais se confirmou nessa falsa personalidade. Diante dessa arte que ainda não é, que apenas se ensaiou em Einsenstein e em mais uma dezena de trechos, cumpre ao filme experimental, ao laboratório, uma longa existência de trabalhos forçados. Sem isso, jamais tornar-se-á realidade o 'imponderável' que é o tal tempo fora do tempo. E, dessa crise de cineramas e coloridos, - sem a experiência que busque uma tradição formal para a nova arte que será - penetraremos numa era do visual fantástico, instrumento de sistemas políticos e econômicos. Aplicando-se mais, no Brasil, torna-se urgente esse trabalho mesmo se for para conhecimento da própria gramática do cinema narrativo, primarismo ignorado por quantos enchem as casas de projeção e elegem o cinema seu pão espiritual de cada dia. O drama do cinema é mais agudo

\footnotetext{
${ }^{115}$ Glauber Rocha, "Filme experimental: um tempo fora do tempo", Angulos, Salvador (BA), ano IX, n. 13, maio 1959, p. 104.

${ }^{116}$ Glauber Rocha, "Filme experimental: um tempo fora do tempo", Angulos, Salvador (BA), ano IX, n. 13, maio 1959, p. 106.
} 
do que se pensa: não se sabe ainda desse atual que está em crise. Como saber do futuro?

Sem dúvida, é a maior responsabilidade e desafio do artista moderno" ${ }^{117}$.

Cabem umas observações finais sobre o tratamento do objeto cinema dado por Glauber em Ângulos. É nítido que o seu debate formal, por vezes defendendo uma arte pura para o cinema, está ligado também às condições de transformação do campo cultural naquele momento. O jovem crítico trazia consigo um duplo envolvimento do período: com um pensamento mais formalista e outro mais próximo da esquerda intelectual.

Os artigos sobre cinema em Ângulos demonstram que Glauber optou por falar de modo mais formalista. Entre outras coisas, sua razão de escolha talvez estivesse também ligada a sua estratégia pessoal de valorização da nova arte, em que já desejava e presumia, mais cedo ou mais tarde, entrar de cabeça como artista. Nessa linha de raciocínio, nada se apresentava como mais estratégico do que ajustar num mesmo patamar de comparação o cinema e a literatura em seus aspectos formais. Calibrados pelas suas diferenças e similitudes, Glauber poderia mostrar para os intelectuais de seu campo cultural, sobretudo os que ainda estivessem encharcados do universo literário, o mundo do cinema. Uma nova opção para se explorar.

Se pensarmos que toda uma tradição cultural brasileira estava em boa parte demarcada pelo espírito literário de longa data, não pareceu mau negócio tentar demonstrar para seus jovens ou seus leitores mais velhos a viabilidade do cinema como uma nova prática artística. Também é preciso reconhecer que o cinema com anseio artístico, no caso brasileiro, ainda estava em formação, fugindo aos críticos a abundância material de exemplos nacionais para o debate e os diálogos virtuais com os respectivos autores. Longe de um mundo do cinema realizado em nosso território e com dinâmica artística própria, restava a muitos críticos a especulação formal sobre a nova arte.

Ângulos, nesse horizonte, é para Glauber um espaço aberto para sinalizar o cinema como arte cheia de aspectos formais e valor artístico íntegro. É evidente que o entendimento do jovem crítico não se restringiu a isso. Estava também em curso, como ainda veremos de modo mais detido adiante, uma reflexão sobre o problema do estilo em sua perspectiva nacional e desenvolvimentista, quando a componente social angaria a força de

\footnotetext{
${ }^{117}$ Glauber Rocha, "Filme experimental: um tempo fora do tempo", Ângulos, Salvador (BA), ano IX, n. 13, maio 1959, p. 106.
} 
condicionante da forma fílmica e seus arranjos estarão sujeitos à nossa situação de subdesenvolvimento. Uma inspiração que talvez se mostre de imediato no caso de suas análises do ideário modernista pela literatura, momento de suas apaixonadas leituras do romance social de José Lins do Rego, um dos que mais admirou. 


\title{
II. O ensaísta em formação. O profissional na imprensa entre 1958-1962
}

\begin{abstract}
Lembro do pianista David Tudor, em 1961/1962, apresentando peças de John Cage no Salão Nobre da Reitoria da Universidade da Bahia - aquele prédio gozado do bairro de Canela que sempre me parecerá maravilhoso -, a sala cheia, o professor Koellreutter observando. Uma das composições previa que, a certa altura, o músico ligasse um aparelho de rádio ao acaso. A voz familiar surgiu como que respondendo ao seu gesto: 'Rádio Bahia, Cidade do Salvador'. A plateia caiu na gargalhada. A cidade tinha inscrito seu nome no coração da vanguarda mundial com uma tal graça $e$ naturalidade, com um jeito tão descuidado, que o professor Koellreutter, entendendo tudo, riu mais que toda a platéia.

Caetano Veloso, no prefácio ao livro de Antonio Risério, Avantgarde na Bahia
\end{abstract}

\section{Crítica no Jornal da Bahia}

O Jornal da Bahia surgiu em Salvador no fim de 1958, no dia 21 do mês de setembro para ser mais preciso, numa edição de 36 páginas. Foi uma iniciativa de um antigo militante do Partido Comunista, João Falcão, que se tornou um empresário bem sucedido na cidade baiana e que havia sido, nos idos de 1938, um dos fundadores do periódico militante comunista Seiva, revista que conseguiu alongar-se por quase duas dezenas de números, sendo em seguida extinta pela ditadura do Estado Novo de Getúlio Vargas, já em 1942. Com uma proposta distinta do que oferecia os demais jornais baianos da época, que sempre estavam de alguma forma regidos sob os auspícios de líderes políticos (ou instituições políticas) de perspectiva local ou regional - Diário de Notícias e Estado da Bahia (Assis Chateaubriand), A 
Tarde (Ernesto Simões Filho), Diário da Bahia (Partido Social Democrático), O Imparcial (Franklin Albuquerque) -, não demorou que o Jornal da Bahia estivesse rodeado de jovens ávidos em desempenhar o primeiro trabalho profissional de imprensa ou de antigos militantes do partidão.

De imediato, em face aos demais veículos, o periódico é visto - e assim se autodivulgou - como jornal moderno, com farto noticiário e orientação nacionalista e independente. Registra-se que é o primeiro jornal baiano a introduzir o lead entre suas reportagens. A circulação desse novo jornal baiano foi recebida em Salvador como um marco da imprensa local. Ainda sob o impacto da primeira tiragem e da inauguração de suas instalações no dia anterior ao da sua primeira circulação, onde se aglomeravam figurões baianos, as mensagens chegam de todos os cantos, de diversas classes, pessoas e instituições. Vieram da União dos Estudantes da Bahia, na figura do então presidente Edvaldo Ribeiro da Silva: “É com máxima satisfação que a UEB, órgão máximo dos universitários baianos, vem até a presença de V.S. expressar os seus melhores votos de êxito a este órgão de imprensa que surge fadado a preencher uma lacuna que há muito existe no cenário jornalístico de nosso Estado." . Vieram do representante da Imprensa Oficial do Estado, do sr. Perev Cardoso: "Impossibilitado de comparecer à inauguração do JORNAL DA BAHIA, venho saudar os seus dinâmicos diretores por essa iniciativa, que vem certamente integrar-se no patrimônio da imprensa baiana que hoje assiste à conspurcação da nobre missão jornalística, por aqueles que fazem comércio de inverdades e calúnias. Que seja o JORNAL DA BAHIA padrão de pureza jornalística que tanto esperamos”2. Vieram da agência de notícias Telepress, que distribuía notícias para todo o território brasileiro, numa dessas divulgações ela informou: “Terá a Bahia mais um jornal, mais uma tribuna livre, independente, altiva, para defesa dos seus alevantados ideais de liberdade e consciência de seus deveres cívicos. Mais um órgão de imprensa colocado em mãos hábeis para pugnar pelos seus sagrados direitos e colocar-se no primeiro plano entre os demais da Federação"3.

Os gestos para o veículo não paravam por aí. Até os próprios concorrentes noticiavam a chegada do Jornal da Bahia. O vespertino A Tarde, em sua edição extra da segunda-feira, no dia 22, informa seus leitores sobre a chegada do novo veículo: “Ontem

\footnotetext{
1 "Jubilo e aplausos de todas as classes", Jornal da Bahia, Salvador (BA), 23 set. 1958, p. 5.

2 "Jubilo e aplausos de todas as classes", Jornal da Bahia, Salvador (BA), 23 set. 1958, p. 5.

3 "Jubilo e aplausos de todas as classes", Jornal da Bahia, Salvador (BA), 23 set. 1958, p. 5.
} 
circulou o primeiro número do 'Jornal da Bahia', em quatro cadernos, apresentando farto noticiário e boa matéria opinativa. Registrando o merecido êxito do caçula da imprensa baiana, enviamos a todos quanto lá trabalham o nosso abraço cordial”. Nesse mesmo dia 22, com menos alarde que o anterior, no vespertino Estado da Bahia, dos Associados, registrouse também a novidade: "De aspecto moderno e obedecendo a uma orientação nacionalista, conforme seu editorial de apresentação, o 'Jornal da Bahia' apresentou uma edição de trinta e seis páginas. Sábado último, com a presença de altas autoridades e convidados teve lugar a inauguração de suas instalações".

No nosso caso, a importância desse novo jornal deve-se a outro fator. Foi o primeiro veículo de grande imprensa a incorporar de modo profissional os jovens de Mapa.

Desde o primeiro exemplar, Glauber iniciou suas contribuições. Manteve-se como crítico permanente do jornal até o final do primeiro trimestre de 1959, para em seguida continuar suas colaborações de modo mais esporádico. Para o jovem crítico, o jornal abriu possibilidades de atuação por duas frentes logo conquistadas, deixando de lado a improvável carreira de direito, escolhida sob pressões sociais e familiares. Embora possa ser vista como uma atividade, na época, para que o jovem angarie algum dinheiro, há que se reconhecer que a função de repórter da editoria policial levava Glauber a percorrer aspectos inéditos da vida social baiana a um jovem de classe média. Com participações anteriores em outros jornais e revistas, fazendo correr sua pena de crítico cultural, seu retrospecto levou-o ao contato imediato com a seção cultural do jornal e ele não demorou a assumir também a posição de crítico de cinema no periódico e a edição do suplemento cultural com circulação aos domingos.

Ainda que num primeiro momento se possa dizer que seu papel ficou restrito à apresentação dos filmes em cartaz na cidade, suas críticas seguiram outros rumos. Seus textos ganharam tonalidades mais combativas, com pontos de vistas políticos mais demarcados, transformando seu espaço no jornal para além das mornas resenhas cinematográficas. Se a função de repórter de polícia e a de crítico cultural diário, como se deve supor, não eram papéis complementares, por outro lado não eram incompatíveis. Com um trabalho muitas vezes concentrado durante a noite, a editoria de polícia fazia com que o crítico pudesse reservar seu tempo durante o dia para a formação cultural e para a organização de suas ações, coisa que outro emprego poderia incompatibilizar. Jornal da Bahia era, sem dúvida, um veículo mais próximo das ideias progressistas que percorriam a cidade naquele momento. 
Nessa perspectiva o veículo oferecia ao jovem jornalista uma liberdade, ainda que dentro de certos limites, que o impulsionava pela prática quase diária da crítica cinematográfica, por conseguinte, ao exercício do ensaio de ideias.

As características singulares do periódico permitiam que o jovem jornalista tecesse críticas também às instituições há muito estabelecidas na cidade. Foi o caso da reportagem "A casa dos homens imortais. Terminam candidatos críticos mais irreverentes da academia”, publicada a 24 de outubro de 1958, cujo centro do debate é a Academia de Letras da Bahia e seus acadêmicos. Irônico e ao mesmo tempo agressivo em seu discurso, Glauber deixa clara sua recusa aos homens - todos eles acima dos seus 40 anos - de medalhões dourados no peito que ostentam "uma cadeira austera" que "permitem-lhes a coroa da

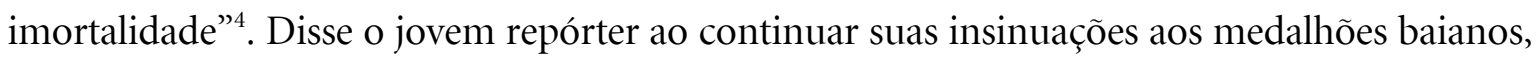
supondo serem estes os mais bem estabelecidos do campo cultural baiano:

"O homem comum vive na cidade, vê o pôr-do-sol, mergulha no sal do mar, ilumina-se à luz da lua e prossegue pobre mortal. Mas há homens que nascem com uma coisa chamada musa, pousada no ombro esquerdo. Esses não passam da rua ao sol, nem do mar à lua com a ingenuidade de seus outros irmãos. Não. A musa tem um sentido de mágica captação, faz da rua um verso, da lua uma rima, do sol um terceto, do 'mar azul' uma chave de ouro, de tudo isto um soneto e daí um passaporte para a glória. E da glória, possivelmente, para a Academia. Eis aí o segredo da imortalidade" ${ }^{n}$.

A tal imortalidade é salientada por Glauber em chave crítica para demonstrar sua consciência sobre as posições demarcadas no circuito artístico baiano: os muros da métrica que ainda envolviam aqueles homens; o franco tradicionalismo literário por eles defendidos; a recusa de ideias modernistas e a ambição de muitos poetas e romancistas locais por aquele espaço mítico, mesmo aqueles que zombavam dos eleitos. Como escreveu o jovem Glauber destes últimos: "dizem que na Academia não há sinceridade e outras coisas. Um dia acordam e lêem no jornal, ouvem no rádio, recebem a notícia por qualquer outro meio: - Morreu o acadêmico número... O literato então vislumbra uma réstia de luz na fronteira da

\footnotetext{
${ }^{4}$ Glauber Rocha, "A casa dos homens imortais. Terminam candidatos críticos mais irreverentes da academia", Jornal da Bahia, Salvador (BA), 24 out. 1958, p. 1.

${ }^{5}$ Glauber Rocha, "A casa dos homens imortais. Terminam candidatos críticos mais irreverentes da academia", Jornal da Bahia, Salvador (BA), 24 out. 1958, p. 1.
} 
imortalidade. Revisa seus sonetos, suas teses ou seus romances e, passando a assumir um ar sério de quem critica a proclamar: seus antigos conceitos, começa. - Bem...apesar das falhas há sinceridade na Academia. Depois, escreve pedindo votos. Os amigos aceitam, a Academia sorri simpática e, data marcada, soneto em punho, desprezo pelo temor da morte, o intelectual cruza solenemente e austeramente os umbrais"'.

Sem talvez passar pela cabeça daquele jovem crítico do jornal baiano, a ironia maior viria a acontecer mesmo no futuro, quando todos os seus companheiros de outrora (Fernando da Rocha Peres, Florisvaldo Mattos, João Carlos Gomes Teixeira, João Eurico Matta) tornariam os tais homens imortais, com direito a medalhão dourado e tudo mais. Teriam eles vislumbrado "uma réstia de luz na fronteira da imortalidade"? Talvez sim, talvez não. Esta, porém, é outra história, uma história do presente que aqui não convém. Voltemos à nossa história de tempos atrás.

\section{Do repórter de polícia à crítica na coluna "Jornal do Cinema"}

Um antigo forte no Largo de Santo Antonio é o cenário onde o jovem repórter entra para fazer sua primeira reportagem. Acompanhado dele está o fotógrafo, o responsável pelos registros visuais do ambiente. Os tempos são outros em Salvador e no lugar agora funciona a Casa de Detenção da Bahia. Por uma divisão rústica, homens e mulheres dividem quase o mesmo espaço. Eles, mais numerosos, ocupam a parte maior. Elas, em menor número, a parte menos espaçosa. Sem penitenciária, a acomodação adaptada fazia com que presos, à espera de um julgamento, aglomerassem à espera de um socorro. Firmava-se uma ilegalidade ali. Restava ao repórter contar essa história de precariedade.

O repórter não demorou a se dar conta da situação. Já dentro do local e acostumado à vida de classe média sem muitas aventuras, ele começa a observar a vida daqueles presos. Um deles se aproxima do jovem repórter. Tímido no início, o preso “tropeça nas palavras", mas não demora a engrenar uma boa conversa. Ele, o preso, quer aprender qualquer coisa, um ofício. Não aguenta mais ficar ali sem fazer nada. São meses e meses em

\footnotetext{
${ }^{6}$ Glauber Rocha, "A casa dos homens imortais. Terminam candidatos críticos mais irreverentes da academia”, Jornal da Bahia, Salvador (BA), 24 out. 1958, p. 1.
} 
cárcere sem nada a fazer. Mostrando-se habilidoso, o jovem jornalista consegue acalmar o nervosismo do pobre rapaz que conta sua história, possivelmente similar a tantas outras ali:

"Fui preso há um ano por tentativa de roubo (cita o artigo em que está enquadrado). E até agora não sei o que vai ser de mim. Não tenho advogado. Eu quero pedir socorro a alguém. O que é que eu vou fazer? - e novamente se descontrola quase chorando".

Não é o único que pede socorro. Muitos vão deixando as conversas em grupo, outros deixam a brincadeira com as arraias voadoras, todos vão se aglomerando no pátio. Cada um quer deixar o repórter a par de suas próprias histórias, tão sofridas quanto à anterior. "Uma centena de homens pede socorro", escreve o repórter em seu bloco de anotações. Organizam-se em fila para que o jovem jornalista, já assustado com toda aquela cena, pudesse recolher os depoimentos. Aqueles que estavam em celas fechadas espremem-se para deixar um pequeno bilhete, relato que poderia ser o último daquela situação. Na pressa, um tanto que assustado, o repórter os guarda e, feito autoridade, faz promessas de lê-los, atender às reivindicações e buscar resolver o problema. Continua suas entrevistas.

Ele dá conta que aqueles presos têm nomes.

O repórter fala com Serapião Oliveira Santana, preso há sete anos e que ainda esperava por seu julgamento. Sequer tinha conhecimento do andamento de seu processo. Agostinho Cardoso, outro preso que estava ali há seis anos, aproxima-se perto do repórter. Tira a camisa, mostra-lhe a costela "saltando do tronco magro". Daquele corpo feito esqueleto que saía a confissão. Firmava-se o descaso das autoridades. Eram vãs as tentativas do pobre preso em arrumar advogados. Ali não se fazia justiça. Os pobres coitados não sabiam o que era isso.

Triste, talvez abalado, diante daquela precarização generalizada, o repórter ainda perguntaria ao diretor do presídio sobre aquela situação, o sr. Lafaiete Spínola, que em resposta apenas diria: "Negligência dos juízes".

O jornalista, atônito diante dos fatos e das observações, registra a situação alimentar daqueles homens e mulheres. Em sua cabeça firma-se a cena do homem sem dentes que exibe um prato de carne seca. Seu único alimento. Não deixa de anotar a cena em seu bloco: "Carne seca para um homem sem dentes". Deste homem, o jornalista se aproxima, e começa a ouvir o seu drama:

"Eu não tenho dentes e me dão isso para comer. Há dias sofro passando fome. Estou com diarréia de sangue”. 
Em meio às suas anotações, o repórter ouvia a queixa comum, sintetizada em uma só fala logo por ele transcrita: "nosso principal problema aqui eu resolvo com uma palavra: fome". Tomava umas últimas anotações para a denúncia. Passava por celas imundas. Ouvia outras reclamações. Pedia que o fotógrafo registrasse tudo. Sua primeira matéria foi seu primeiro desafio que de longe ultrapassou o âmbito jornalístico policial ${ }^{7}$.

É bem possível que tenha sido esta a cena enfrentada por Glauber diante do seu desafio prático em escrever sua primeira reportagem policial para o Jornal da Bahia. Na leitura desse seu primeiro texto, cuja publicação é 21 de setembro de 1958, fica patente que o repórter policial, dado que é um iniciante na função, é de fino e bom faro. Numa perspectiva moderna, embora sumária, de jornalismo, suas qualidades seriam assim evidenciadas: provoca seu leitor, analisa o problema central sem fazer espetacularização com a vida alheia, sabe extrair de sua fonte aquilo que é essencial. Nota, enfim, que a situação é séria e deve ser tratada como tal. Como não poderia ser diferente, o jovem repórter já possui a marca do jornalismo moderno de então, cujas modificações advindas desde a introdução do lead americano e dos primeiros manuais de redação na organização sobretudo do Diário Carioca, em 1950, já se faziam repercutir na capital baiana pela proposta desse mesmo e recente Jornal da Bahia.

Como registrei antes, embora esse mundo policial possa ter calibrado certos olhares do jovem Glauber, que comiserava diante daquelas assimetrias, nosso maior comentário em relação ao seu trabalho no Jornal da Bahia deve-se aos seus textos de abordagem culturalista. E nesse quesito não são poucos os exemplos do empenho do jovem crítico baiano. Mesmo não sendo seu primeiro espaço de atuação como crítico, o Jornal da Bahia oferecia o primeiro lugar para o exercício continuado da crítica do objeto artístico. Certos fatores, entre eles a passagem mesmo que amadora pelas revistas culturais Mapa e Angulos, além de seu interesse constante pelo mundo das artes em geral, facilitavam sua adaptação à prática de se fazer quase um texto por dia.

Somado a isso, a seu favor ele tinha uma redação nova, com uma tradição hierárquica mais flexível, ou seja, estava, Glauber, sem um grande medalhão para lhe fazer certa sombra. Desde o início, ele e outros companheiros seus receberam a missão de estabelecer as linhas críticas do novo jornal no que se refere à cobertura do campo artístico

\footnotetext{
${ }^{7}$ Cf. Glauber Rocha, "Centenas de homens pedem socorro do interior de um antigo forte", Jornal da Bahia, Salvador (BA), 21 set. 1958, p. 4.
} 
baiano. Criou a seção diária denominada "Jornal do Cinema", a qual ele manteve sob sua tutela e pôde, desse modo, escrever críticas de cinema todos os dias, de setembro de 1958 até o início de 1959. Um exercício que praticou quase sem interrupções por todas as edições do período. A liberdade de escolhas temáticas ultrapassava o mundo do cinema, escrevendo sobre outros assuntos que bem achasse pertinente. Vendo esta singular oportunidade, tratou logo de publicar artigos sobre literatura e teatro. Mais do que cobrir os filmes em cartaz, o jovem Glauber pôde criticar justo e injustamente estabelecimentos, distribuidoras de filmes, pessoas e instituições do circuito artístico baiano, bem ao seu estilo que mais tarde seria sua marca de enfrentamento.

Para o momento, saliente-se o caso de seus artigos sobre o cinema em cartaz na cidade.

Nesse período, em que ele assume a posição de crítico permanente da coluna de cinema, partes das suas contribuições focalizaram os filmes à disposição na cidade, muitos deles americanos clássicos ou filmes europeus com boa distribuição. Em alguns momentos diga-se de passagem, não tão raros - Glauber dá as costas à narrativa fílmica. Seu propósito é refletir sobre a própria situação do circuito de cinema em Salvador, controlada por grandes empresas distribuidoras estrangeiras. Há outros momentos em que Glauber deixa delinear o seu perfil de gosto, de um jovem crítico buscando, por ele mesmo, identificar as linhas de sua própria filiação e os valores críticos por ela pautados. Tarefa, esta, executada na análise de filmes "mais autorais" - os de sua preferência - e de filmes mais industriais dos grandes estúdios. Se, em mais de uma vez, Glauber, em seu percurso, deixou clara sua insatisfação com a falta de bons filmes nas distribuições locais, ele também não deixou de demonstrar, como atitude crítica, suas preferências sobre o que considerava o bom e o mau cinema - o exemplo mais adequado e o menos adequado para o nosso cinema em formação.

Muitos artigos publicados no Jornal da Bahia expressam apenas um tratamento informativo dos filmes em cartaz. Por demonstrarem pouco de seu ponto de vista mais agudo, portanto menos polêmico, estes interessam menos. Interessam-me muito mais os registros em que se evidenciem suas opções de gosto.

Nesse horizonte, entre as muitas possibilidades, foram emblemáticos, sob nossa ótica, os artigos escritos por Glauber para sua coluna na ocasião da exibição de dois filmes: Glória feita de sangue, de Stanley Kubrick, e As virgens de Salém, de Raymond Rouleau. Digo 
emblemáticos, porque oferecem um contraponto interessante para se pensar a posição do crítico e suas prováveis alianças, em termos de gosto, a um tipo de cinema.

As análises juvenis de Glauber em relação ao cinema americano antes de mais nada são uma amostra bastante segura de como as motivações de gosto sempre estão sujeitas às experiências realizadas em mais de um momento na fase de formação e experimentação dentro de uma determinada trajetória, demonstrando o aspecto heterogêneo que demarca um território social amplo a que um intelectual está subordinado.

Mesmo mais tarde, quando já dispunha de certa notoriedade perante os mais influentes do nosso campo cinematográfico, Glauber não esquecia, e sempre que possível fazia questão de salientar com tintas fortes, a influência do cinema americano que acompanhou durante sua juventude na capital baiana. Certa ocasião, em 1964, num debate coordenado pelo crítico e cineasta Alex Viany para se discutir Deus e o Diabo, Glauber lembrou a influência de certos filmes e de certos diretores americanos sobre o seu labor de cineasta; disse ele: "Para o desgosto de muita gente e de você [Alex Viany], a fita tem muita influência do western. Tem muita coisa de John Ford, que vocês não gostam mas eu adoro, e o Antônio das Mortes é uma figura de citação fordiana mesmo: a forma de ele aparecer, a forma de ele andar, o uso da paisagem, a aplicação da balada. Até o massacre tem muita gente metida..."

O exemplo trazido por Glauber trança, sem cair no ramerrão das fáceis explicações sobre as influências de um autor, um aspecto que caracteriza o seu perfil crítico, demonstrando seu rol de interesses: o aspecto autoral de um diretor (no caso John Ford) é mais bem valorizado que a defesa de um gênero. Naquele momento, vale para ele os aspectos autorais de um cinema que buscasse uma correta exploração da linguagem fílmica em sua potencialidade de expressão. Nisso, John Ford, mesmo um representante do que poderia se considerar o status quo do cinema americano do momento, ganhava notoriedade para Glauber.

Voltando ao tempo de suas críticas juvenis no Jornal da Bahia, sua análise sobre Glória feita de sangue é concebida em linha de análise similar. O jovem crítico, em seus dois primeiros textos a respeito do filme, pouco esclarece sobre esse seu posicionamento. $\mathrm{O}$ primeiro artigo, publicado a 25 de setembro de 1958, embora projete uma empatia com a narrativa, não vai além de uma resenha morna para descrever o percurso de dificuldades da

\footnotetext{
${ }^{8}$ Glauber Rocha, depoimento em Alex Viany, O processo do Cinema Novo, 1999, p. 70.
} 
produção de Kubrick e James Harris, quando os grandes estúdios americanos recusaram-se a bancar a produção nos moldes que o roteiro original estabelecia. O segundo artigo é ainda mais morno. Publicado em 22 de outubro de 1958, Glauber faz apenas uma compilação de trechos elogiosos de jornais do Rio de Janeiro.

O posicionamento do jovem crítico só se torna mais contundente em seu terceiro artigo "Glória feita de sangue (I)", em 4 de novembro de 1958, mas ainda não é uma definição que marca sua aliança entre a análise da linguagem de seu objeto e aquilo que ele postula como valor crítico e artístico mais alto. O fio condutor de sua análise é o perfil temático em que a narrativa se enquadra e o que esta pode trazer de reflexão histórica sobre o homem e sua realidade. Embora tendo a guerra como cenário central, Glauber alerta seu leitor que o filme de Kubrick não deva ser classificado como uma narrativa de guerra (entendida aqui como um emaranhado de ações de violência, vitórias e derrotas). Porque antes de ser enquadrado como tal, o filme deve ser pensado como experimento que não fixa a guerra como assunto principal, mas sim como pretexto para a denúncia da desumanidade dos exércitos. Na essência dessa perspectiva está o elogio ao autor do filme, que "faz de qualquer tema apenas ponto de partida para denunciar o homem e suas circunstâncias" ${ }^{\prime \prime}$ Em mais de uma vez, chama atenção do jovem crítico a maneira com que Kubrick compõe suas denúncias, dizendo "certas verdades pelas vozes de seus personagens" ${ }^{10}$, uma voz que Glauber observa ser indignada e rebelde. Seu ponto de vista é assim desdobrado:

\footnotetext{
"Por esse aspecto é que, embora exteriormente, Paths of Glory [Glória feita de sangue] deva ser considerado um filme de guerra; por outros ângulos mais profundos, o consideraríamos melhor um filme cujo tema não é limitadamente militar, social, histórico, político. É uma temática mais universal: a desumanidade sem localização justa na história, mas todo o mal que vem inato no homem desde o seu princípio e que aqui, numa guerra e pela alma de oficiais, se revela. Mas poderia ser uma injustiça cometida em qualquer classe, como vemos em nossos dias, e podemos verificar também no passado"11.
}

No dia seguinte, a 5 de novembro de 1958, Glauber publica o complemento do texto anterior, sob o título "Glória feita de sangue (II)". Não é mais a temática da guerra

\footnotetext{
${ }^{9}$ Glauber Rocha, “Glória feita de sangue (I)", Jornal da Bahia, Salvador (BA), 04 nov. 1958, p. 3.

${ }^{10}$ Glauber Rocha, "Glória feita de sangue (I)”, Jornal da Bahia, Salvador (BA), 04 nov. 1958, p. 3.

${ }^{11}$ Glauber Rocha, "Glória feita de sangue (I)”, Jornal da Bahia, Salvador (BA), 04 nov. 1958, p. 3.
} 
abordada pelo cineasta americano o seu eixo de discussão. Os esforços de Glauber agora estão concentrados no projeto formal de Kubrick. Ao distinguir a perspectiva analítica do cineasta americano, o jovem crítico demonstra o aspecto que mais valoriza no diretor de Barry Lyndon: "O grande engano de certa crítica tem sido pensar que Kubrick é um puro formalista. O certo, porém, é que nunca houve cineasta tão participante, tão dentro da alma do homem, justamente de onde retira suas imagens. Com rigor a imagem de Kubrick não é a imagem superficial, descritiva ou narrativa. Sua câmara capta a interioridade do homem como ele vê, capta, fala e ouve o mundo"12.

De modo positivo, o jovem crítico enxerga no cineasta americano uma forma de narrar distinta do que se supunha ser a prática de um cinema mais convencional dos grandes estúdios americanos. Kubrick transformou-se, para ele, em um anti-modelo de padronização de filmes americanos, estes que, por princípio, conduziam-se, sobretudo, pelo apelo de uma história linear, baseada na intriga e constituída a partir de uma linguagem sem muitas variações com constante reprodução em todo o circuito de seus realizadores. Para Glauber, Kubrick seguia outra linha: deformava este padrão, sem, no entanto, criar uma repulsão de leitores/espectadores. Glória feita de sangue é o filme que contempla uma síntese desses aspectos formais trabalhados pelo cineasta, quebrando a barreira entre a intriga e a exploração da linguagem cinematográfica. Destacando certas sequências desse filme, escreveu o jovem crítico sobre os aspectos formais mais importantes em sua concepção:

"Seqüência na qual três soldados saem em patrulha de reconhecimento. A atuação
do som se faz em pulsações de tambores contraponteados por rajadas de
metralhadoras, dois sons que se conjugam, um transmitindo o ruído real e outro o
ruído irreal, psicológico. As pulsações sonoras seriam como as pulsações íntimas
do medo. A alternação ousada de montagem entre fusões de grandes planos gerais
e grandes primeiros planos. Nos planos gerais, plasticamente, existe o campo de
batalha e sua ruína tenebrosa. Entre mortos e destroços, diluídos na paisagem, os
três soldados avançam. Nos primeiros planos estão as imagens do medo. A
individualização do homem ante a morte no centro da noite violenta. E as
pulsações sonoras crescem e diminuem conforme pulsam os corações. Logo
depois, uma região de perigo, para onde segue um soldado. Grande plano mostra
o lugar violento claro escuro, logo depois esfumaçado, como um inferno. A
permanência desse plano, alternando por sua vez com os primeiros planos dos

\footnotetext{
${ }^{12}$ Glauber Rocha, "Glória feita de sangue (II)", Jornal da Bahia, Salvador (BA), 05 nov. 1958, p. 3.
} 
dois soldados que esperam o terceiro. Esse lento e profundo jogo de montagem do 'inferno' (o grande plano do campo devastado onde se consumira um dos três soldados) e do 'medo' (primeiros planos dos dois soldados fixando o 'inferno') termina por atingir uma saturação do tempo cinematográfico que coincide exatamente com a saturação psicológica dos soldados-personagens. Então o medo explode"13.

Entre outras coisas, o trecho citado do artigo de Glauber deixa patente seu interesse pela categoria narrativa do tempo. Ele valoriza o cineasta que encontra o refúgio do cinema moderno pelo viés do trabalho autoral da montagem que penetra na análise do tempo, deixando em segundo plano o argumento e a intriga. Em seus aspectos de montagem de som e imagem, a análise da sequência do filme de Kubrick feita demonstra isso. Nela, configuram-se lado a lado a ideia de um tempo real, aquele constituído pela vida material e prosaica de cada personagem, e o tempo psicológico, este resultado da saturação do tempo cinematográfico, transformando-se no ponto de contato entre o leitor/espectador e o que há de fluxo de consciência do personagem em questão.

A depuração da categoria do tempo na narrativa e sua construção a partir de elementos híbridos de montagem ganham especial importância para Glauber em mais de um momento de sua trajetória intelectual. Longe de estabelecer uma relação direta e mecanicista entre essa análise por ele implementada em torno do filme de Kubrick e as suas experiências artísticas e ensaísticas, ainda assim é possível notar seus experimentos que aliam montagem e construção do tempo narrativo.

Saindo do convencional, cujo exemplo mais imediato talvez seja a sequência final de Terra em Transe, em que o personagem Paulo Martins agoniza nas dunas em meio à mistura atordoante da música de piano e dos sons de metralhadoras e sirenes, trago à tona um exemplo de uma peça teatral escrita por Glauber e que se encontra depositada no Tempo Glauber, no Rio de Janeiro. Nela, na peça, o efeito técnico de uma mistura também de imagens e sons caminha no sentido de constituição de uma categoria narrativa que coloca em análise o tempo histórico. Sob o título de Jango (tragedya em 3 atos), essa peça datiloscrita em 42 páginas em papel tamanho ofício, cuja datação indicada é de 1976, é divida em três atos e um prólogo. Seu enredo gira em torno do personagem histórico Jango, referência direta ao ex-presidente João Goulart, que discute com outros personagens históricos e não-

\footnotetext{
${ }^{13}$ Glauber Rocha, "Glória feita de sangue (II)", Jornal da Bahia, Salvador (BA), 05 nov. 1958, p. 3.
} 
históricos a vida política brasileira. Para que se tenha uma visualização mais clara a respeito dos efeitos híbridos configurados na peça e sem entrar muito nos aspectos do enredo e das tramas dos personagens do referido texto, entendendo que este não é o objetivo aqui, veja-se a passagem emblemática de uma das rubricas no primeiro ato:

\begin{abstract}
"Alguns músicos já batucam e tocam saudando Betty. Jango desce a escada onde é sempre assediado por personagens que o abraçam e o festejam. O samba bomba come solto. Balé - além de West Side Story. Alto falantes transmitem o samba/enredo. Nova versão sobre o seqüestro do Embaixador... CIA capta o Embaixador pra facilitar golpe Imperialista contra golpe nacionalista... Tudo se transforma numa passeata típica de 1968. Canta Caetano no vídeo. Gil. Gal. Chico. Vandré. Roberto Carlos. Em alguns planos do cenário vemos cenas de assalto. Noutros, cenas de tortura. Caos. Violências. Todos se transformam em operários de várias raças que gritam sob a violência do trabalho. Rajadas de metralhadora. Bomba de gás. Todos tossem. Som. Música muda. Carnaval. Dançam travestidos, pulam, gritam, fazem amor, estão mais tarde desacordados e cansados sobre as cadeiras, camas, pelo chão e nos degraus da escada. Alguns vestidos, outros rasgados, outros nus. Desaparecem as imagens no vídeo” ${ }^{\text {. }}$.
\end{abstract}

Se o aspecto de fusão de sons e imagens foi o que chamou a atenção de Glauber em relação ao filme de Kubrick, esse mesmo aspecto ganha outras tonalidades para o trabalho com o tempo narrativo em sua peça. Cabem alguns comentários a esse respeito. Em Jango não está em jogo a fusão com o propósito de demonstrar um tempo memorial do personagem, seu aspecto de tempo real e irreal (psicológico), como diria (e disse) o jovem crítico. Vale, sim, como as fusões de elementos tão distintos, porém ordenados dentro de uma perspectiva histórica, ganham a marca de um tempo que se torna o emblema da própria história do momento. As rubricas são o preparo para a entrada do coro, que na peça alegoriza-se como voz popular. Seu autor pensa que antes da atuação dessa voz, é preciso criar o terreno, demonstrar de onde ela irradia. Por isso, elementos tão díspares se ordenam num aparente caos para evidenciar a marca desse desejo libertário em relação a uma ideia de exploração colonizadora, cujo símbolo é o imperialismo yankee. A análise pormenor da peça indica que três formas de tempo, em perspectiva histórica, estão em jogo nessa composição: o tempo da revolução, o tempo da violência e o tempo da estética. O tempo da revolução

\footnotetext{
${ }^{14}$ Glauber Rocha, Jango (tragedya em 3 atos), p. 12. [material inédito, Tempo Glauber, Rio de Janeiro (RJ)].
} 
funcionando como aspecto do desejo de libertação nacional e da resistência à marca americana. O tempo da violência é, de uma só vez, a marca do sofrimento do trabalhador cooptado pelo mundo do trabalho e a marca da necessidade violenta de luta libertária da voz popular. O tempo da estética é o que resiste, é aquilo que pode se tornar o motivo de libertação e o avanço para a revolução. Embora aqui o exemplo possa ter sido tratado talvez de modo sumário, é preciso ressaltar que a validade do trecho está em apontar o uso técnico feito pelo autor de uma marca que lá atrás já chamava sua atenção. E não se trata de uma marca qualquer, é algo que acompanhou Glauber em mais de um momento em seus textos, em suas obras cinematográficas, talvez na sua própria fala, quando se lançava a falar aos quatro ventos, misturando aspectos de sua memória e aspectos de análise da nossa realidade.

Fechados os parênteses sobre essa adesão glauberiana em relação aos efeitos da fusão de elementos em uma narrativa, volto a outros textos do Jornal da Bahia. Destaco também aquilo que Glauber considerou os maus exemplos de um autor no cinema. $\mathrm{O}$ contraponto fica a cargo de dois artigos: “As virgens de Salém”, I e II, ambos sobre o filme homônimo de Raymond Roleau.

No primeiro artigo, de 16 de outubro de 1958, o jovem crítico iniciou com uma velha pergunta: "o que é mais importante, no filme: o argumentista ou o diretor?" 15 . Dentro das suas estratégias para se tornar um crítico reconhecido e distinto entre os demais críticos locais e a outros que pudessem interessar, é evidente que sua resposta defenderia o cinema como arte independente, portanto valorizando a direção como o aspecto principal para o reconhecimento do filme como obra de arte.

Na concepção de Glauber, As virgens de Salém é um filme que, embora apresente bom argumento, de uma adaptação feita por Jean-Paul Sartre com base em uma peça teatral de Arthur Miller, fracassa como objeto artístico de cinema. Na concepção do crítico do Jornal da Bahia, Arthur Miller é um exemplo de incisivo e corajoso homem de teatro americano. Numa linha de crítica ácida ao capitalismo americano de então, o original teatral As virgens de Salém passava em revista, não deixando de denunciar, "as raízes americanas da tara coletiva pró-linchamento e intolerâncias racial, religiosa e política" ${ }^{\prime 6}$. O caso de Jean-Paul Sartre é idêntico ao de Miller no sentido que também oferece subsídio privilegiado para o trabalho cinematográfico de Roleau. O filósofo francês é visto por Glauber como homem

\footnotetext{
${ }^{15}$ Glauber Rocha, “As virgens de Salém (I)”, Jornal da Bahia, Salvador (BA), 16 out. 1958, p. 3.

${ }^{16}$ Glauber Rocha, "As virgens de Salém (I)”, Jornal da Bahia, Salvador (BA), 16 out. 1958, p. 3.
} 
habilidoso em adaptações e no tratamento de temas polêmicos como era o caso do texto de Miller. Não se pode esquecer que Sartre já havia tido a oportunidade, em outro momento, de trabalhar por si mesmo o tema da intolerância e do racismo em seu texto $A$ prostituta respeitosa, de 1946.

O início do segundo artigo, cujo título é “As virgens de Salém (II)” e foi publicado em 17 de outubro de 1958, retoma as ideias contidas no primeiro artigo: "como vimos, os autores do argumento e do roteiro de 'Le sorcières de Salem' (Arthur Miller e JeanPaul Sartre) ofereceram ao diretor Raymond Rouleau um material de categoria para que se realizasse filme em elevado nível artístico" ${ }^{\prime 17}$.

Segundo Glauber, Roleau fracassa como realizador de As virgens de Salém. Fracassa, pois pouco faz de cinema diante da adaptação, apenas constitui uma transposição do texto teatral, sem o cuidado de transformar sua matéria textual em "imagem como princípio fundamental", disse o crítico. Em outros termos, o diretor aceita a encenação teatral, quando deveria, sob a concepção do crítico, criar uma atmosfera cinematográfica sem monotonia, fazer cortes nos longos diálogos teatrais, transformar o suporte do roteiro como base para uma forma moderna de tragédia no cinema. Um verdadeiro experimento de cinema, e não de teatro. Glauber é duro e exigente. Para ele, o diretor francês "fracassou por medo, por covardia intelectual, por submissão que a arte cinematográfica não deveria sofrer da literatura" ${ }^{\prime 1}$. Por sua perspectiva de valorização do que seja autoral em cinema, Roleau transformou-se no seu mau exemplo. Glauber não hesita: o exemplo que não deve ser seguido, afinal o cinema é coisa séria para intelectual empenhado. Em outras palavras, o jovem crítico construía uma de suas marcas que, naquele momento, representava o sentido e o valor dessa sua movimentação no espaço de sociabilidade cultural e na imprensa.

\section{Disseminação das ideias nacionais pelo cinema: defesa da arte dos moços na Bahia}

Sem dúvida, dentro da geração intelectual da qual Glauber faz parte, o cinema tornou-se coisa séria. Uma seriedade nunca antes vista no campo cinematográfico brasileiro.

\footnotetext{
${ }^{17}$ Glauber Rocha, “As virgens de Salém (II)”, Jornal da Bahia, Salvador (BA), 17 out. 1958, p. 3.

${ }^{18}$ Glauber Rocha, "As virgens de Salém (II)", Jornal da Bahia, Salvador (BA), 17 out. 1958, p. 3.
} 
Projeto de um desejo coletivo de muitos deles, a arte do entretenimento transformara-se, para aqueles jovens dos anos 1950, em arte para se refletir o Brasil, quando não - alguns deles pensavam - para contribuir no desenvolvimento econômico e cultural do país. Se efetivado, esse projeto poderia colocar o país e sua cultura em pé de igualdade com os centros consagrados de produção e difusão cinematográfica e artística, no pós-guerra: França e Itália, por assim dizer, como exemplos mais almejados por alguns intelectuais.

Foi nesse contexto que Glauber achou por bem privilegiar também o espaço da coluna "Jornal do Cinema" no Jornal da Bahia, e dela se utilizar, para tecer suas defesas em prol do desenvolvimento do nosso cinema como projeto ligado à representação do aspecto nacional. Não havia quem estranhasse seu recado, desde que tivesse um mínimo de afinidade a essa forma de pensamento: "Façamos um trabalho pelo cinema brasileiro. Isso é nacionalismo"19, sempre que podia escrevia Glauber sem hesitar. Acompanhar o colunista nessa jornada não é tarefa das mais fáceis. Em primeiro lugar, suas defesas, por sinal numerosas entre o fim de 1958 e início de 1959, podem estar explicitadas numa convencional argumentação ou, em casos mais difíceis de detectar, elas se revelam nas entrelinhas de seu discurso - entre uma ideia e outra na exposição e crítica de um filme, por exemplo. Em segundo lugar, seus ânimos, quase sempre exasperados, tingem seus textos ao ponto de muitas vezes sua argumentação dar voltas, conduzindo-se por percurso espiral, levantando sinais de uma compreensão mais complicada do que já é em situações mais normais.

Na Bahia, como é sabido, o final daquele decênio dos anos 1950 é o tempo de movimentações por todos os lados. O jovem crítico Glauber, munido das páginas do Jornal da Bahia, tal como outros críticos - exemplifique-se Walter da Silveira, Flavio da Costa, David Salles, Hamilton Correia -, levantou a bandeira do cinema baiano e o seu papel de constituição de uma visão nacional. Sua tarefa no veículo, digamos, passou por duas grandes missões bastante demarcadas e, certamente, por ele delineadas como estratégia de atuação local para se tornar mais respeitado e conhecido no circuito de especialistas e leitores. São elas: a defesa do cinema nacional como arte, constando neste caso os textos de cunho mais programático em que se agendavam debates e discussões sobre a nova arte; e a defesa das primeiras realizações baianas como plataforma para a nova geração de cineastas locais. Por trás de um ou de outro texto, Glauber sempre perpassa seu propósito educador ancorado em uma argumentação que esclarece questões em relação à expressão artística do cinema. Eram

\footnotetext{
${ }^{19}$ Glauber Rocha, “Cinema nacional sabotado”, Jornal da Bahia, Salvador (BA), 15 nov. 1958, p. 3.
} 
questões que, para o crítico, ultrapassavam, em longe, o manejo e domínio técnico da arte cinematográfica tão-somente. Qualquer oportunidade é motivo para que Glauber institua um espaço de debates e de afirmações de suas próprias convicções. É modelar, neste sentido, a carta que recebe de um de seus leitores. De imediato, Glauber faz uma breve e incisiva resposta. Embora um pouco longa a citação, acompanhe-se a seguir carta e a resposta, dada a importância do registro deste modo pouco usual em se tratando de um crítico de jornal. Trata-se do colunista que aproveita cada brecha para deixar às claras seu ponto de vista:

"Recebemos hoje uma carta que investe contra a crítica de cinema. Democraticamente publicamos e respondemos.

Caros senhores:

Antes de mais nada queremos parabenizar o JB [Jornal da Bahia] pela lacuna que veio preencher em nossa imprensa em vários, senão todos os setores da informação, razão pela qual certas atitudes críticas nossas parecerão bizantinas, sem fundamento, mormente em se tratando de um setor especializado.

Não caberia aqui maior digressão (sabemos ser caro o espaço de jornal) e por isso vamos logo ao tema que nos levou à redação desta.

Queremos nos referir à seção de cinema do JB. Aparentemente, esta não tem importância, e a nossa crítica, como dissemos acima, pareceria sem fundamento, não fosse a obrigatoriedade de uma informação precisa, dada a proporção que a arte(?) tem na vida cotidiana das cidades no que toca ao divertimento(?). A bem dizer, de início, (e por isso interrogamos) ainda não conseguimos saber, e graças aos complicados críticos e responsáveis pelas seções de cinema dos jornais, dos quais o do JB é um espécimem antológico, como realmente devemos entender o cinema como arte nem como divertimento, nem quando ambas as cousas juntas. Acreditamos que a confiança de uma seção especializada na imprensa significa uma valorização que escapa à percepção e alcance de um leitor comum, mas temos também por certo, que toda a 'estória', é feita em função daqueles para os quais a imprensa é feita.

Cordialmente,

Antonio Barbosa.

RESPOSTA BREVE E ACCESSÍVEL

A carta do Sr. Antonio Barbosa denuncia inteligência mas também inteligência atrasada cerca de setenta anos. Além disso, muito sutil o Sr. A. B., figura que conhecemos e que prima pela sua permanente invocação dos Deuses passadistas e que hoje só podem ressuscitar pelo poder evocador, criador e recriador do cinema, o que procura afirmar é que, tanto o cinema quanto a imprensa, são fenômenos degradantes. 
Deveria se lembrar, ele que é tão fluente em Latim que Lucrecio em 'DE NATURA RERUM' já falava do sonho como elemento evocador e editor de imagens, o que significa uma antecedência muti-secular do problema cinematográfico. Demais, a tarde faz muito calor"20.

Feito esse registro anterior, cabe começar por um de seus artigos de defesa.

Em edição dominical e da segunda-feira, a 25 e 26 de janeiro de 1959, ele escreveu o artigo intitulado "Nota breve: o intelectual e o cinema". É um texto que, a um só tempo, Glauber faz uma radical defesa que mescla dois pontos principais: a análise do cinema como projeto intelectual para as novas gerações e o ataque às "velhas gerações". O início do artigo é a base de seu recado dirigido àqueles que ainda suspeitam do valor artístico da nova arte. Sem meias palavras, destila seu ataque: "Qualquer posição intelectual contra o cinema surge exclusivamente da ignorância em torno de uma nova linguagem, desconhecimento de causa que redunda às avessas: não dominando seus processos expressionais o intelectual autosuficiente na sua medida de inteligente e culto - deduz ingenuamente que o fenômeno trata-se 'apenas' de uma questão de técnica ajudada artisticamente pela literatura e pelo teatro. Poderá no máximo reconhecer uma importância publicitária e, sobretudo, um 'perigo à moral cristã' ou uma arma 'política' de grande força sobre as massas"21.

Sua demonstração apóia-se no entendimento de que o cinema é constituído de uma forma própria, tal como as outras artes. Portanto, a nova arte deve também fazer parte de um projeto intelectual sério. Ou seja, em sua defesa está implícito que o cinema, a exemplo da literatura, deve almejar um espaço sério e autônomo dentro das produções culturais. Nessa discussão, ele faz um deslocamento do cinema visto pela velha geração sob o viés ético ou político para uma compreensão estética. Segundo Glauber, o erro desses velhos intelectuais é compreender o cinema como "síntese de artes e de conhecimentos" e não reconhecer o potencial de linguagens que o cinema pode oferecer. A questão entre a defesa da nova linguagem e a encampação desta ideia por Glauber torna-se um problema geracional, como ele escreve:

\begin{abstract}
"Se de um plano, as 'velhas gerações' reagem tão cientes e enganadas, as 'novas gerações' reagem mais intencionais e mais dispostas. Todavia perduram quase
\end{abstract}

\footnotetext{
${ }^{20}$ Glauber Rocha, “Carta a J.C.”, Jornal da Bahia, Salvador (BA), 13 dez. 1958, p. 3.

${ }^{21}$ Glauber Rocha, "Nota breve: o intelectual e o cinema”, Jornal da Bahia, Salvador (BA), 25-26 jan. 1959, p. 3.
} 
sempre na intenção e na fé. Criadas mais participantes dessa mitologia universal de luz e sombra, conhecendo inicialmente um novo mundo na infância que os passados não conheceram, as 'novas gerações' entendem mais profundamente que existe essa categoria de 'universo' - qualquer que ele seja - em sua perspectiva de rota intelectual. Pecam, porém, e mais gravemente, pois se intuem a linguagem não lutam por dominá-la crentes de que a sua 'intuição' é uma rede fixa de domínio: o resultado é também às avessas. Colocado diante da reação geral, fracassam nas defesas frágeis de elementos demonstrativos da nova arte. E por vezes, arrebatados na adolescência pelos impulsos das 'filosofias' ou 'políticas' subvertem arbitrariamente os seus conceitos e o cinema passa também, como passa entre os 'outros', a ser o instrumento de 'verdades'”22.

Como se nota, o problema geracional não é apenas abordado por Glauber a partir dos pólos da submissão e do domínio de realizadores e críticos do campo cultural baiano - entre os mais novos e os veteranos. No que toca à questão geracional, sua crítica está envolta por duas dimensões: uma delas se volta para o mais óbvio de sua posição, deixando palavras certeiras para os estabelecidos que não enxergavam o cinema com bons olhos, e a outra se volta para o que ele chamou de o "intelectual de hoje" que por ventura estivesse tratando o cinema de modo equivocado.

Diante do novelo emaranhado, Glauber propõe desatá-lo com uma possível solução para o problema. Seu recado salienta que era preciso, em termos de atitudes de uma ou outra geração, um esforço de pensamento e uma ação de uma prática de estudo para a compreensão do cinema além do seu aspecto ético e político. Trata-se de uma posição - a mesma repisada em outros artigos seus - que propõe "encarar o cinema como fato estético e não como fato qualquer"23.

Nesses artigos de defesa da arte cinematográfica no Jornal da Bahia, há aqueles casos em que o crítico deixa o problema estético de lado para discutir a especificidade do campo de realizações do nosso cinema e a sua ambiência local.

Em 14 de dezembro de 1958, Glauber publicou o artigo "Indústria de cinema na Bahia”. Seu teor é um só: demonstrar a viabilidade econômica de se constituir um mercado e uma indústria de cinema na Bahia. Quase como um alerta ao seu leitor, Glauber se dirige aos "homens de negócios". Seu exemplo é a Iglu Filmes (a primeira produtora de cinema na

\footnotetext{
${ }^{22}$ Glauber Rocha, "Nota breve: o intelectual e o cinema”, Jornal da Bahia, Salvador (BA), 25-26 jan. 1959, p. 3.

${ }^{23}$ Glauber Rocha, "Nota breve: o intelectual e o cinema", Jornal da Bahia, Salvador (BA), 25-26 jan. 1959, p. 3.
} 
Bahia, na qual à época Glauber é um de seus produtores), que havia recebido uma boa quantia de investimento a partir do jovem capitalista de Itabuna, Elio Moreno Lima.

Falando aos seus contemporâneos, o artigo propaga uma possível aliança entre desenvolvimento regional e nacional e a formação de uma indústria de cinema. Tal aliança, em sua concepção, vislumbrava um avanço em termos de perspectiva econômica. Os exemplos trazidos pelo crítico são muitos: caso dos Estados Unidos, do México, Itália e França, cujos cinemas eram divisas interessantes para estes respectivos países. As vantagens de um investimento em cinema seriam assim enumeradas por Glauber:

“a) das cidades brasileiras, Salvador é a que maior fama possui no Brasil e no exterior pela sua já tão decantada paisagem. Daí, a dedução lógica de filmes com tema, natureza, gente e música baiana, serem produtos de fácil aceitação nos mercados nacional e internacional. Isto significa que o cinema na Bahia levaria vantagem sobre todas as produções nacionais, cujo produto em noventa e nove por cento é pessimamente consumido pelo mercado nacional, isso devido à má qualidade dos filmes carnavalescos e à precariedade dos filmes mais sérios, procurando sempre uma fórmula de baixo-custo, o que degenera em falta de acabamento técnico.

b) Estruturada e organizada dentro dos padrões comerciais das grandes produtoras internacionais e beneficiada pela falta de costumeiros tipos viciados em produção de 'aventura' - uma vez que na Bahia são poucos os aventureiros; e evitando-se a vinda desses elementos contaminadores que teriam seus lugares tombados por técnicos e artistas de qualidade. [...] É preciso, porém, muito cuidado com elementos estrangeiros. Se tal negócio se desenvolver em nossa terra é caso também para se evitar em tese todos os estrangeiros que se dizem 'cineastas'”24.

Talvez não reste dúvida que a historicidade desse texto glauberiano - e esses dois itens demonstram de algum modo isso - guarde em si um diálogo com um código presente em outros textos de mesma época. Refiro-me nesse debate contemporâneo à marcante presença do desenvolvimento econômico e sua relação com a produção cultural erudita. Mais que isso, implícita à ideia de desenvolvimento nacional desse tempo, a que Glauber está intimamente ligado, está uma corrente que não vê com bons olhos a presença estrangeira, tida muitas vezes como imperialista. Glauber aplica a fórmula do desenvolvimento ao

\footnotetext{
${ }^{24}$ Glauber Rocha, “Indústria de cinema na Bahia”, Jornal da Bahia, Salvador (BA), 14 dez. 1958, p. 3.
} 
cinema. Daí se explica o seu recado final, em tom de alerta, para o problema da importação do modelo estrangeiro em termos de produção e realização de nosso cinema, embora, saliente-se, o crítico ainda ressalte a importância de se espelhar no que seria um modelo comercial de indústria estrangeira bem sucedida. Vera Cruz, a grande companhia paulista que ambicionou fazer cinema de grande estúdio na São Bernardo do Campo dos anos 1950, é o seu exemplo de recusa dessa presença de fora: "somente devido a afluência de italianos e alemães que vieram acabados da Europa se aventurar no Brasil, foi que a Vera Cruz paulista faliu" ${ }^{\prime 25}$.

Como se notou até o momento, o jovem crítico já rebateu a falta de entendimento do objeto cinematográfico entre duas gerações e já entoou seu recado aos empresários locais para que pudessem investir numa desejada indústria de cinema baiano.

Para engrossar esse coro a fim de configurar seu entendimento crítico de cinema sob os pilares da concepção e teorias, produção e difusão, desenvolvimento e apoio financeiro, restava ainda a Glauber no espaço do Jornal da Bahia firmar sua posição sobre as salas e a distribuição dos filmes nacionais. É o caso do artigo, de emblemático título "Cinema nacional sabotado", cuja publicação deu-se em 15 de novembro de 1958. Beirando a reclamação, seu texto é um registro da falta de filme nacionais lançados em circuito baiano. Para Glauber, "há uma rede bem organizada contra o filme nacional", que estaria obrigando exibidores em Salvador, quando estes se interessassem por filmes brasileiros, a contratar também um filme americano sem expressão e de pouco apelo comercial. O suposto saldo para o exibidor local e para os espectadores seria pérfido ao desenvolvimento da arte cinematográfica brasileira em sua concepção: "O que ganhar com o filme brasileiro, será perdido no prejuízo que os abacaxis americanos trarão depois. Como casa de exibição é casa de negócio, o proprietário não topa o jogo e o filme brasileiro, quando consegue ser lançado, é em espelunca de segunda categoria, como o Aliança"26.

Com essas críticas, como as enumeradas antes, o jovem Glauber encontrou uma maneira de criar uma plataforma de discussão de problemas, tanto em nível teórico como em nível de organização produtiva da realidade cinematográfica em termos locais. Somado a isso, ainda bastante esclarecedor percorrer suas críticas em torno da defesa dos filmes e autores nacionais.

\footnotetext{
${ }^{25}$ Glauber Rocha, "Indústria de cinema na Bahia", Jornal da Bahia, Salvador (BA), 14 dez. 1958, p. 3.

${ }^{26}$ Glauber Rocha, "Cinema nacional sabotado", Jornal da Bahia, Salvador (BA), 15 nov. 1958, p. 3.
} 
Começo por um filme local. Trata-se de Redenção, de Roberto Pires, o primeiro filme de longa-metragem baiano. Antes mesmo do seu lançamento, que ocorreu em 1959, Glauber já anunciava nas páginas do Jornal da Bahia as novidades sobre o filme. Em 9 de outubro de 1958, ele escreveu o artigo “ 'Redenção' - primeiro filme baiano”, em que relata as dificuldades, as perspectivas de acertos e as possíveis contribuições da película que ainda era finalizada. Entre suas estratégias, encontra-se o posicionamento do filme como avanço para o desenvolvimento local, sob dois aspectos: em termos econômicos, pela nova atividade que poderia se formular; em termos culturais, trazendo para a Bahia os holofotes da consagração cultural em nível nacional ou mesmo latino-americana.

Acompanhem-se os passos dessa sua construção narrativa em torno da produção de Redenção. Após breve explicação do envolvimento quase amador de Elio Moreno Lima no financiamento da produção, o destaque fica por conta de Roberto Pires. Modulado pelo tom de aventura em fazer cinema em território baiano, sua narração demarca elementos que registram o aspecto pioneiro e, ao mesmo tempo, amador de se fazer cinema sem as adequadas condições do trabalho:

“O diretor de 'Redenção' é Roberto Pires. Trabalha na casa Mozart, é óptico. Vem com Oscar Santana (fotógrafo) tentando cinema há muito tempo. Primeiro, com máquina de dezesseis milímetros, rodou alguns filmezinhos experimentais. Depois, fez uma lente cinemascópica (que ele chama de processo 'ultrascope') e resolveu, ainda com Oscar, a aventura 'Redenção'. Começaram fundando a 'Iglú Filmes' e, sem muita experiência, mas muito intuitivos e confiantes, arrumaram bagagens. Filmaram aos sábados à tarde, quando deixavam o trabalho e entravam pelas noites e seguiam pelo domingo até a madrugada"27.

Ao registrar a inexperiência do autor de Redenção no trabalho técnico de filmagem da película, o que resultou, à época, em perda dos primeiros copiões do filme, o crítico do jornal baiano traz à história desta produção um elemento alheio à realidade local. Do Rio de Janeiro, viera Hélio Silva, "técnico consciente, entendido em planificação de produção, experiente em três filmes ('Rio, quarenta graus', 'Rio, Zona Norte' e 'O grande

\footnotetext{
${ }^{27}$ Glauber Rocha, “'Redenção' - primeiro filme baiano”, Jornal da Bahia, Salvador (BA), 09 out. 1958, p. 3.
} 
momento')"28. A chegada do técnico, segundo o crítico, garantia a qualidade fotográfica do filme.

Apesar de esta crítica apontar Redenção como um filme com problemas de argumento e direção, sobressai-se em seu ponto de vista o registro generoso do empenho daquela equipe de rapazes. Eram moços que sequer tinham alcançado a casa dos 30 anos, e, mesmo diante de todas as dificuldades, tinham conseguido fazer um filme "vivo, movimentado, tem ritmo, tem cara de cinema mesmo" ${ }^{29}$. Não parece ser à toa que o crítico do Jornal da Bahia fazia questão de sublinhar o peso da idade de cada um deles. A ênfase, outra vez, estava na geração, na qual Glauber se incluía. Em outras palavras, significava uma clara situação impressa e dita a quem quisesse ouvir: a transformação da nova arte dependia do empenho de cada um deles, por "gente que acredita no cinema brasileiro do futuro" 30 .

Em todo caso, o exemplo desse caráter e preocupação com o nosso cinema era visto por Glauber nas próprias pretensões confessadas a ele pelo diretor desse primeiro longametragem baiano: “'Redenção’ não tem igreja, praia, capoeira, Senhor do Bonfim, candomblé e abará. Esse tema Roberto Pires preferiu deixá-lo intocável a estragá-lo. E isso, essa resistência auto-crítica a enfrentar as seduções superficiais do ambiente baiano, já é o suficiente para marcar o caráter de Roberto Pires e de toda sua equipe”31. Glauber sabia que as qualidades impressas em Redenção não poderiam elevar o filme à categoria de obra-prima. Por essas e outras, que sua opção buscou demonstrar que se tratava de uma narrativa pioneira. Segundo Glauber, era o sinal de que a Bahia "está ficando grande", ou, com algum exagero, "que a província não existe mais". Nessa dinâmica, ninguém poderia ficar de fora, era preciso que todos prestigiassem a chegada nas telas de Redenção. Era o prestígio não de um filme, mas de um novo cinema que estaria por vir, segundo suas palavras:

\footnotetext{
"Mesmo que não gostem, que achem abacaxi, paguem a entrada, dêm ( sic) sua contribuição para que eles façam outro melhor, porque eu sei que a honestidade deles quer cinema de primeira linha. Criemos a mística de 'Redenção' como se cria a mística de político em tempos de eleições. E, por falar em política, o Estado e a Prefeitura devem prestigiar, com prêmios, o primeiro filme baiano"32.
}

\footnotetext{
${ }^{28}$ Glauber Rocha, “'Redenção’ - primeiro filme baiano”, Jornal da Bahia, Salvador (BA), 09 out. 1958, p. 3.

${ }^{29}$ Glauber Rocha, “Redenção” - primeiro filme baiano”, Jornal da Bahia, Salvador (BA), 09 out. 1958, p. 3.

${ }^{30}$ Glauber Rocha, “'Redenção’ - primeiro filme baiano”, Jornal da Bahia, Salvador (BA), 09 out. 1958, p. 3.

${ }^{31}$ Glauber Rocha, “'Redenção’ - primeiro filme baiano”, Jornal da Bahia, Salvador (BA), 09 out. 1958, p. 3.

${ }^{32}$ Glauber Rocha, “'Redenção’ - primeiro filme baiano”, Jornal da Bahia, Salvador (BA), 09 out. 1958, p. 3.
} 
Menos de dois meses depois deste artigo, Glauber publicou outro texto sobre o mesmo assunto. Estampado nas páginas do Jornal da Bahia em 4 de dezembro de 1958, portanto, quase às vésperas da estréia de Redenção nos cinemas baianos, sua ênfase está na necessidade de que o público prestigie o filme. Para o crítico, era necessário perdoar as falhas do filme, não falar mal da película e fazer deste um grande sucesso. Porque estava em jogo a prosperidade da arte desses moços cineastas. Nesse sentido, Redenção chegava para quebrar a "intransigência crítica" de alguns e para mostrar que a Bahia tem cinema também. Segundo Glauber, bastava ao povo ser bairrista e "bater no peito: 'Redenção' é nosso pouquinho. Quem desprestigiar Roberto e sua equipe, apenas cometerá um erro, um crime de má fé. Solidariedade, apoio moral, vontade e ação de dizer, 'para a frente', devem ser os lemas do público. Esperemos e confiemos"33.

Exposto o exemplo local e defendido com unhas e dentes, é momento de explicitar o ponto de vista do crítico a partir de um filme não-baiano. Em termos práticos, esse novo conjunto de críticas em torno do filme de Nelson Pereira dos Santos, Rio, Zona Norte, fora produzido de modo quase concomitante à favorável crítica dedicada à Redenção, o que se pode sugerir que ambas as defesas talvez não sejam tão dissociáveis assim.

Com Rio, quarenta graus, filme anterior de 1955, Nelson Pereira conhecera o entusiasmo da crítica, gerando grandes expectativas para os trabalhos que viriam dali em diante. Foi nesse clima, mistura de empolgação e confiança, que Rio, Zona Norte fora apresentado ao público em fins de 1957. E diferente do seu primeiro filme, as reações no calor da hora não foram, nem de longe, as mesmas.

Os entusiastas de Nelson no passado, com a nova película, tornaram-se os seus mais ácidos críticos. De todos os lados, por todos os flancos, esse novo filme recebeu críticas quase sempre desfavoráveis. Não era pouco para um jovem cineasta, ainda tateando por um espaço de consagração, estar na mira dos nossos principais críticos: Alex Viany, Paulo Emílio, B. J. Duarte, Ely Azeredo, Salviano Cavalcanti ${ }^{34}$ - só para citar a massa de críticos mais influentes do momento que não receberam bem Rio, Zona Norte. Poucos foram os que se manifestaram a favor do filme. Poucos mesmo. Nesse rol de isolados, José Lino Grünnewald,

\footnotetext{
${ }^{33}$ Glauber Rocha, "Notas e comentários de cinema na Bahia", Jornal da Bahia, Salvador (BA), 04 dez. 1958, p. 3.

${ }^{34}$ Cf. Mariarosaria Fabris, Nelson Pereira dos Santos: um olhar neo-realista?, 1994, pp. 151-152.
} 
crítico do Jornal do Brasil, foi um deles. Lá da Bahia, ainda que com repercussão local, Glauber também se mostrou favorável. Cabe analisar seu ponto de vista de momento.

Em 18 de dezembro de 1958, o crítico do Jornal da Bahia publicou seu primeiro texto sobre Rio, Zona Norte. Sem ainda percorrer a narrativa fílmica, Glauber elabora um artigo para comentar as rotinas e os percalços de gravação e produção de Rio, Zona Norte. Este foi o modo, digamos, que o jovem crítico havia encontrado para desvendar ao público a "vida íntima do filme” ${ }^{35}$. Para isso, Glauber se fixa no diário de produção do filme, cujo amplo material é a base para demonstrar seu ponto de vista sobre a situação precária de se filmar no Brasil. A demonstração dessa rotina passa por um jogo argumentativo. Próximo de uma construção heróica, a habilidade das palavras glauberianas estabelece o seguinte confronto: de um lado, está esquematizado um sistema social sempre disposto a sabotar a nova concepção do cinema brasileiro em formação; de outro, estão aqueles que, feito bastiões do nosso nacionalismo, fazem do cinema uma profissão de fé - Nelson, neste último caso, é o seu legítimo representante, dado seu alcance ampliado.

Às vésperas do lançamento de Rio, Zona Norte no circuito baiano, Glauber mais uma vez evidencia o valor de Nelson Pereira dos Santos cineasta, em artigo de 21-22 de dezembro de 1958. O título desta sua crítica demonstrava o significado de Nelson para as ideias do jovem crítico: "Importância de Nelson Pereira dos Santos". E o início do seu texto dá o tom dessa abordagem: “[...] Nelson é um cinema social, humano, participante, colocando forma em função do tema. Falemos hoje de Nelson Pereira dos Santos detalhadamente: sua luta inicial em 'Rio, quarenta graus', sua luta seqüenciada em 'Rio, Zona Norte', sua luta que prossegue em busca de cinema que ele julga ser o caminho para o brasileiro. Falemos do homem, o pouco que conhecemos, e mais do cineasta: um espírito lúcido, honesto, talentoso"36.

A revelação dos aspectos físicos de Nelson, que sugere a construção de uma personalidade sólida para o nosso cinema, é a primeira parte desta construção de perfil biográfico. Em ano anterior, 1957, Glauber havia acompanhado, no Rio de Janeiro, parte das filmagens ${ }^{37}$ de Rio, Zona Norte. Dessa experiência, o crítico reconstitui suas boas impressões

\footnotetext{
${ }^{35}$ Glauber Rocha, "Rio, Zona Norte”, Jornal da Bahia, Salvador (BA), 18 dez. 1958, p. 3.

${ }^{36}$ Glauber Rocha, "Importância de Nelson Pereira dos Santos", Jornal da Bahia, Salvador (BA), 21-22 dez. 1958, p. 3 .

${ }^{37}$ Cf. Glauber Rocha, Cartas ao mundo, 1997, p. 85. [carta de 22 mar. 1957, Rio de Janeiro (RJ), endereçada por Glauber a Fernando da Rocha Peres].
} 
do cineasta. Segundo ele, o sorriso simpático do rapaz baixo e magro revelava confiança e inteligência ímpar. Dito isso, Glauber parte para salientar as características mais marcantes deste novo cineasta. Após breve descrição do estado do campo cinematográfico brasileiro, o jovem crítico situa Nelson como o legítimo representante de um cinema reflexivo. O cinema de Nelson faz com que todos os críticos ou a "parte inteligente do público"38 parem para se pensar nos problemas brasileiros.

Nesta estratégia de defesa e de nomeação de aspectos que compõem um cineasta de importância cultural sem precedentes no Brasil, Glauber encara Nelson como o representante do neo-realismo italiano por aqui. Visto de forma positiva, as ligações do autor de Rio, Zona Norte são, portanto, com a vanguarda do pós-guerra. Sobre isso, escreve o crítico: "lições marcantes de Zavattini”, o "ritmo de Umberto D", a "influência de Visconti”, "um artista que cria, utilizando bem as lições daqueles cineastas que ele elegeu como seus mestres" ${ }^{39}$. A base dessa defesa ainda se faz pelo tipo de produção que o cineasta de Rio, quarenta graus adota. Acima de tudo, Nelson é para Glauber um cineasta social:

\begin{abstract}
"Homem participante, Nelson jamais recusaria o que costuma chamar 'conteúdo social e mensagem' - E essa preocupação de procurar refletir na tela os problemas sociais do Rio de Janeiro, fundamentalmente o miserável Rio das favelas foi o que chocou os espíritos retrógrados do Brasil, principalmente as autoridades responsáveis pela denúncia de injustiça e pela revelação da humanidade do morro" ${ }^{\prime 4}$.
\end{abstract}

Próximo ao final daquele ano de 1958, Glauber continuava a dispor do espaço de sua coluna no Jornal da Bahia para falar de modo favorável de Rio, Zona Norte. O crítico entrevistou seu conterrâneo Guido Araujo ${ }^{41}$, assistente de direção do filme de Nelson, e escreveu uma nova crítica em que, além de se posicionar mais uma vez a favor da película, também reafirma certas dificuldades de se fazer cinema em solo subdesenvolvido.

\footnotetext{
${ }^{38}$ Glauber Rocha, "Importância de Nelson Pereira dos Santos", Jornal da Bahia, Salvador (BA), 21-22 dez. 1958, p. 3 .

${ }^{39}$ Glauber Rocha, "Importância de Nelson Pereira dos Santos", Jornal da Bahia, Salvador (BA), 21-22 dez. 1958, p. 3 .

${ }^{40}$ Glauber Rocha, "Importância de Nelson Pereira dos Santos", Jornal da Bahia, Salvador (BA), 21-22 dez. 1958, p. 3 .

${ }^{41}$ Cf. Glauber Rocha, "Guido (Rio, Zona Norte) Araujo fala a Jornal da Bahia", Jornal da Bahia, Salvador (BA), 23 dez. 1958, p. 3.
} 
Publicado em 25 de dezembro de 1958, o artigo, cujo título é "Rio, Zona Norte (II)", é escrito por Glauber para estimular o público baiano a frequentar as salas de cinema com o filme de Nelson. Talvez estimulado por outras críticas que chegavam a suas mãos, o jovem crítico inicia seu texto com a seguinte indagação: "Até que ponto se poderia exigir de uma produção pobre como foi a de 'Rio, Zona Norte', uma perfeição técnica?”42. O problema localizado pelo crítico está ligado às questões estruturais do cinema: torna-se impossível a perfeita realização técnica sem material técnico eficiente à disposição. A lembrança de Glauber está em suas primeiras experiências de realizador com Pátio: "Isso agora podemos dizer com conhecimento de causa: realizando um pequeno filme em companhia de José Ribamar de Almeida e de Marinaldo Costa Nunes, sofremos, podemos dizer que na carne as deficiências materiais de nosso cinema" ${ }^{43}$.

Parece mesmo significativo que o problema dos recursos tenha chamado a atenção do jovem crítico. Não se pode esquecer neste horizonte que Glauber também estava marcado pelas experiências baianas que acompanhou de perto no período e as quais sempre padeceram de dificuldade de financiamento de projetos. $\mathrm{O}$ crítico talvez imaginasse que os espectadores, muitos deles condicionados com o parâmetro técnico do cinema americano, pudessem julgar sob termos negativos Rio, Zona Norte, o que por si só em nada ajudaria aos trabalhos desses novos cineastas baianos.

O Glauber daquele tempo, embora bastante jovem, já tinha relativa consciência de que era preciso demarcar um campo de irradiação para todo e qualquer filme que se julgasse independente dentro do nosso campo cinematográfico. Assim não deixou de agir. Com o aparato de imprensa a sua disposição, Glauber procurou fazer contínuos estímulos em torno dos filmes que representassem seu fascínio, esclarecendo ainda certos tópicos que pudessem gerar qualquer tipo desconfiança ou um olhar desfavorável. É curioso notar a forma como o crítico equaciona a questão para se justificar os problemas técnicos de nossas películas: "enquanto Chaplin filma mil metros para aproveitar cem, no Brasil se filma cem para se aproveitar setenta. Como é possível, em uma produção modesta, paupérrima, como a do 'Rio, Zona Norte' se repetir cenas, se fazer movimentos de câmeras audaciosos?"44. Se seu propósito passou por não atingir, a partir do seu "acabamento técnico e formal”, Rio, Zona

\footnotetext{
${ }^{42}$ Glauber Rocha, "Rio, Zona Norte (II)", Jornal da Bahia, Salvador (BA), 25 dez. 1958, p. 3.

${ }^{43}$ Glauber Rocha, "Rio, Zona Norte (II)", Jornal da Bahia, Salvador (BA), 25 dez. 1958, p. 3.

${ }^{44}$ Glauber Rocha, "Rio, Zona Norte (II)”, Jornal da Bahia, Salvador (BA), 25 dez. 1958, p. 3.
} 
Norte, em exibição naquele momento nos cinemas baianos, talvez a questão polêmica por ele levantada também se encadeie por outros fatores. Em jogo está a ascensão da nova arte no campo cultural brasileiro. E porque não dizer a própria atuação do crítico e sua ambição em se transformar em um nome corrente do nosso cinema, situação que não demoraria a ocorrer.

\section{A um passo do Rio, crítica no Diário de Notícias}

Em final dos anos 1950 e início dos anos 1960, o Diário de Notícias de Salvador era um dos empreendimentos, na Bahia, do poderoso Diários Associados, de Assis Chateaubriand. Salvo engano, o primeiro artigo de Glauber no Diário de Notícias de Salvador data de agosto de 1957, quando ele escreveu o primeiro texto da série "Hollywood e os filmes de delinqüência juvenil”, este mais tarde incluído em seu livro O século do cinema. Portanto, uma colaboração bem anterior ao aparecimento do Jornal da Bahia. Essa primeira fase das colaborações esporádicas estendeu-se até agosto de 1958, momento em que o jovem crítico assume o posto profissional tanto na coluna "Jornal do Cinema" como na editoria policial no novo jornal.

Suas colaborações voltam ao Diário em agosto de 1959, dando início a uma nova fase de textos. Ali, o crítico assume a seção "O cineasta e seu filme", além de contribuir com certa frequência com ensaios de maior fôlego nas páginas do Suplemento Artes e Letras. Contando com o auxílio de Glauber na coordenação editorial, este suplemento circulava na edição de domingo do jornal, juntando-se, como era de praxe na época, às edições das segundas-feiras. Em geral, suas oito páginas eram compostas por temas culturais variados e nelas mesclavam-se nomes de alto prestígio no meio cultural brasileiro e nomes apenas conhecidos em perspectiva local. Em importante levantamento, o pesquisador Benedito Veiga organizou os índices de todas as colaborações feitas entre os anos de 1956 e 1971 no Suplemento Artes e Letras, cujo saldo, publicado pelo autor em livro de reduzida circulação, totaliza mais de 700 autores colaboradores com quase 3200 artigos distintos ${ }^{45}$.

\footnotetext{
${ }^{45}$ Cf. Benedito Veiga, Memória da vida literária baiana: década de 60 (indexação do suplemento dominical do Diário de Notícias: 1956-1971), 2003.
} 
Naquele final de década, Glauber, quase desconhecido no restante do país, vê oportunidade ímpar para figurar ao lado de nomes consagrados da nossa intelectualidade, tais como Otto Maria Carpeaux, Gilberto Freyre, Câmara Cascudo, Antônio Houaiss ou Jorge Amado. Suas colaborações no suplemento estender-se-iam até o início dos anos 1960, época já de intensa correspondência com os grupos intelectuais do Rio de Janeiro.

Da leitura cuidadosa de seus artigos do Diário, procedeu-se de uma divisão que orienta os comentários a seguir.

Entre as ideias mais heterogêneas propagadas por Glauber no periódico, eu dei especial atenção ao tratamento do que chamei de "ideias locais". Refiro-me com isso ao que o crítico, prosseguindo o que iniciara no Jornal da Bahia, oferece de ações e propostas para uma efetiva intervenção no circuito artístico baiano. Em outros termos, demonstrava-se que o crítico havia mudado de veículo, mas mantido seu posicionamento intelectual. Na escolha do que opinar e do que escrever, suas intervenções no Diário sempre se mostraram uma estratégia eficiente. Não só das discussões dos rumos locais, mas também dos temas mais gerais, procurando, sempre que possível, manter uma conexão entre o que ocorria na Bahia e o restante do país. O jovem crítico baiano buscava se distinguir dentro do campo intelectual baiano e mostrar sua ligação com a fina-flor da intelectualidade brasileira de então. Daí se explica a tonalidade de alguns artigos que beira o manifesto de ideias. Ao seu leitor, talvez um novo Glauber começasse a surgir nas páginas do Diário. Se não tão distinto daquele crítico das páginas juvenis em suas publicações organizadas pelo grupo formado no Colégio Central, era já um moço, naquele exato tempo, com um pé na Bahia, mas com os olhos no Rio. Para não dizer com um pé e olho em cada canto.

\section{Por ideias locais no Suplemento Artes e Letras}

Com o Diário, tal como aconteceu com suas colaborações no Jornal da Bahia, o espaço de atuação de Glauber não se restringiu à crítica de filmes, embora ele a tenha praticado também de modo regular, tanto em extensão de temas e abordagens como em intensidade de opinião e de polêmicas. Não são poucos os momentos em que ele foi impulsionado a falar sobre outros assuntos importantes para a vida cultural baiana do início dos anos 1960. Sorveu-se das informações daquele ambiente, extraiu aquilo que lhe parecia 
mais interessante e, a contento e de maneira pouco ingênua, espichou a língua febril para homens e instituições. Fosse ou não figura de seu agrado, Glauber não poupou ninguém.

Como era de se esperar, a literatura foi tema tratado. Para ser mais preciso, a literatura local ganhou destaque nas páginas que escreveu no Diário. Chamou sua atenção o aparecimento de uma literatura baiana realizada por uma nova geração de escritores, o que o levou a registrar tal empreitada como um marco na evolução artística e literária em perspectiva local. Refiro-me ao que está exposto nos artigos "reunião (e Sonia) 1", de 19-20 de março de 1961, e "David \& Ubaldo \& Noenio", de 26-27 de março de 1961. Em ambos os textos, o destaque ficou por conta do livro coletivo Reunião, publicado pelos iniciantes David Salles, Sônia Coutinho, Noênio Spínola e João Ubaldo Ribeiro. Embora o crítico ainda veja o livro como reflexo de um ambiente amador das letras, ele nota entre aqueles jovens um impulso criador fora do comum, denominado por ele como "uma preocupação de rebeldia". Cabe um exame mais de perto da questão e notar que o elogio não se faz à toa, nem tampouco como gesto de explicitação de seu gosto.

Em "reunião (e Sonia)", Glauber inicia seu artigo com o que seria uma constatação do momento, vinda, esta, de sua percepção de analista da realidade local: a Bahia de 1961 ainda vive sob o "signo Rio - São Paulo", caracterizada pelo crítico como um complexo de inferioridade terrível. Feita a constatação, afirmaria que nem tudo estava perdido. Glauber assumiria a ideia lançada por Heron de Alencar em uma entrevista realizada um mês antes. Disse o professor ao autor de Pátio: "a Bahia possui as melhores perspectivas culturais do Brasil”46. E essa perspectiva, entre outras coisas, viria também da literatura, pela atuação dessa nova safra de ficcionistas. É o que Glauber vai tratar.

O jovem crítico é desenvolto com a nossa literatura. Sabe da importância de Guimarães Rosa, sabe o que significou o romance nordestino, sabe de Lúcio Cardoso e de Cornélio Penna, sabe dos novos nomes do momento: Clarice Lispector, Geraldo Ferraz, Dalton Trevisan. Da Bahia, Glauber aponta duas experiências de alta literatura na produção contística daquele momento: "Sol" de Vasconcelos Maia e "Os girassóis, o tempo" de Nelson de Araújo.

E esses novos escritores, objeto de sua apreciação no artigo? Em sua concepção, onde eles se situam no grande campo literário brasileiro e na arte baiana do momento?

\footnotetext{
${ }^{46}$ Glauber Rocha, "Ouvem e revelam Heron de Alencar: um professor Bossa-Nova", Diário de Notícias, Salvador (BA), 26-27 fev. 1961, p. 1.
} 
Glauber chegaria lá. Mas antes faz uma espécie de preâmbulo onde traça um perfil das transformações que a nossa literatura se envolveu. Atribui a Assis Brasil um papel de destaque, quando este assume a função de crítico literário no Suplemento Dominical do Jornal do Brasil. Segundo Glauber, o crítico piauiense "iniciou um verdadeiro choque demolidor contra os valores fáceis, acadêmicos, folgados e preguiçosos que vomitam pelas editoras de romances regionalistas que vão na esteira de Jorge Amado e José Lins do Rego (ou pastiches de Graciliano Ramos); que cavam a glória intelectual fazendo 'moralismo negro', mal digerido dos grandes romancistas do mundo" ${ }^{47}$.

Embora fosse discutível seu ponto de vista, Glauber concede ao referido Suplemento Dominical um papel de relevo. No seu entender, as páginas culturais do jornal carioca haviam promovido uma reviravolta no conto brasileiro de então. Estivera o caderno carioca, na concepção de Glauber, fortalecendo e estimulando os novos escritores de ficção na medida em que suas páginas registravam a franca atividade desses mais moços, sobretudo aqueles que encaravam o conto sem as amarras do pastiche "de clássicos consagrados como Machado de Assis e Graciliano Ramos"48.

Glauber ainda constata que em 1961 o movimento, que ele denomina ser "de Assis Brasil", havia perdido seu aspecto mais violento e de choque: "os primeiros nomes encontram caminho e outros que aparecem já estão mais disciplinados" ${ }^{\text {"9 }}$. Passado aqueles tempos de mudança, era, portanto, época para a visualização de uma nova fase da novelística brasileira. Ele deixa entender que os bons frutos, por certo, viriam de livros como Reunião. É nesse contexto que o crítico insere esses jovens baianos.

Para Glauber, há implícito no referido livro um compromisso de geração para o próprio futuro da literatura. Tanto com a mais nova, pelos seus companheiros de travessia, como com a fração mais velha que os apoiavam. Frisada tal importância de um livro como Reunião, ele critica aquilo que considerou o aspecto amadorístico da empreitada; segundo ele, um motivo que "encalha vocações". Mesmo que de modo intuitivo, Glauber busca definir as relações existentes entre a autonomia de um campo literário local e sua profissionalização; sabia que um campo literário local menos profissional significaria menos oportunidades para os escritores e artistas de sua geração. Desse modo, a característica menos profissional de

\footnotetext{
${ }^{47}$ Glauber Rocha, "reunião (E Sonia) 1", Diário de Notícias, Salvador (BA), 19-20 mar. 1961, p. 1.

${ }^{48}$ Glauber Rocha, "reunião (E Sonia) 1", Diário de Notícias, Salvador (BA), 19-20 mar. 1961, p. 1.

${ }^{49}$ Glauber Rocha, "reunião (E Sonia) 1", Diário de Notícias, Salvador (BA), 19-20 mar. 1961, p. 1.
} 
Reunião começaria no próprio título da obra (a mostrar "estreantes tímidos") e no fato de o livro ter sido publicado pela Universidade da Bahia, por conseguinte com circulação restrita. O que extrair disso? Parece evidente que sua crítica está dirigida à falta de oportunidades para esses jovens talentos, afinal, como Glauber disse, eles "não são famosos e por isto - como sempre - não interessam às editoras nacionais, presas à indústria do livro, à edição do mau livro para um público ávido de sexo \& violência e sub-poesia - no fundo o mesmo público do regular cinema americano" ${ }^{50}$.

Em sua formulação, os quatro escritores que compunham Reunião tinham cada um dentro de suas características a base de uma tal autenticidade necessária à evolução da literatura baiana. Juntos, aqueles escritores completavam-se no seu dizer. Sonia Coutinho era uma virtuosa, "sua técnica literária é perfeita" ${ }^{51}$; David Salles, diferente da autora anterior, promove uma integração cultural em sua literatura, podendo-se dizer que é um "'neoregionalista', isto é, permanece dentro de sua geografia, preso às suas raízes, procurando através de uma expressão nova - planos de universalização para a tradicional temática de nosso melhor romance" ${ }^{52}$; João Ubaldo Ribeiro, de originalidade e forte penetração psicológica, é um contista bastante livre, "sem o menor respeito pela tradição, completamente à vontade dentro de seu espírito moderno e ligado às coisas do mundo todo que gira em torno dele"53; entre todos eles, Noenio Spinola é o escritor mais maduro, mais do que um contista, ele possui o potencial para se tornar um romancista de forte presença em nossa literatura, "parece ser daqueles criadores solitários e obstinados tipo Kafka", é quem melhor dominou a "fase das invenções, plasmando seu trabalho num clima orgânico e inserindo 'choques' novos apenas em determinados momentos" ${ }^{54}$.

Taxativo, o jovem crítico deixa clara sua opinião sobre o que considera primordial para o bom funcionamento de uma lógica de sociabilidade literária de ambientação local. Reitera, em mais de uma vez, que a literatura precisa se profissionalizar e um escritor deve almejar viver de sua própria escrita. Seus parâmetros para defini-la, a literatura, como forma independente de arte passam por discutir o papel e a rebeldia do autor - sua participação, seu sacrifício, seu trabalho exaustivo e, em alguns casos, sua autofragelação

\footnotetext{
${ }^{50}$ Glauber Rocha, “reunião (E Sonia) 1”, Diário de Notícias, Salvador (BA), 19-20 mar. 1961, p. 1.

${ }^{51}$ Glauber Rocha, “reunião (E Sonia) 1”, Diário de Notícias, Salvador (BA), 19-20 mar. 1961, p. 1.

${ }^{52}$ Glauber Rocha, “David \& Ubaldo \& Noenio”, Diário de Notícias, Salvador (BA), 26-27 mar. 1961, pp. 1-2.

${ }^{53}$ Glauber Rocha, “David \& Ubaldo \& Noenio”, Diário de Notícias, Salvador (BA), 26-27 mar. 1961, pp. 1-2.

${ }^{54}$ Glauber Rocha, “David \& Ubaldo \& Noenio”, Diário de Notícias, Salvador (BA), 26-27 mar. 1961, pp. 1-2.
} 
para a garantia de uma justa autenticidade -, mas não só esse aspecto. Sempre que possível ele resvala nas questões que estruturam a prática desse mesmo autor. Os exemplos se espalham em seus textos. Do cinema, vem sua crítica à falta de recursos para as produções, da literatura, sua crítica à falta de investimentos nos mais jovens, fosse do ponto de vista editorial ou promocional desses novos escritores.

Junto ao discurso favorável à nova cepa de escritores, vinha também a defesa de um novo espaço para todo e qualquer artista jovem, desde que - é evidente - suas escolhas estivessem em sintonia com o novo grupo de jovens intelectuais que se formava. Eram tácitas para o principal divulgador daquele grupo, Glauber, as seguintes normalizações: uma arte alinhada ao que havia de mais moderno, uma arte de intervenção social intensa, uma arte que buscasse não só o raio local, mas também uma infiltração nos grandes centros daquele momento - Rio de Janeiro e São Paulo -, expondo os valores locais além dos seus próprios muros. Por ser parte de uma base sólida de discussão, a qual foi se constituindo suas idas e vindas em torno do que considerava o papel social da arte, não surpreendem que esses aspectos ainda fossem tratados em seus textos de alcance local dois anos depois; fica o exemplo de 1963: "Nada posso dizer do que isto, senão lamentar a mentira que é a cultura bahiana oficial, ainda fiel a seus princípios convencionais e políticos. O jovem precisa 'romper' inclusive com certa dose de anarquismo, a fim de conquistar campo para suas ideias" $" 55$.

É preciso sublinhar que 1961 é um ano chave para o jovem Glauber. É crítico de um importante jornal baiano, finaliza sua primeira realização cinematográfica, Barravento, e as portas do Rio de Janeiro parecem cada vez mais abertas para a divulgação de suas idéias. É época ainda em que ele amplia não só seus contatos com jovens cariocas, empenhados também com a constituição de um novo cinema, como também os laços com outras frações da intelectualidade brasileira. Inúmeros e de variadas linhagens são os seus interlocutores. Veja-se o caso de uma intensa troca de cartas daquela época entre Glauber e um dos líderes da organização do cinema cubano no início dos anos $1960^{56}$. Em relação a Alfredo Guevara, homem forte dentro do Instituto Cubano del Arte e Indústria Cinematográficos (Icaic), o cineasta baiano se mostra bastante simpático com os rumos do cinema cubano, deixando evidente, sempre que possível, suas intenções de manter um contato estreito de intercâmbio

\footnotetext{
${ }^{55}$ Glauber Rocha, "Nota sobre David”, Diário de Notícias, Salvador (BA), 10 mar. 1963, pp. 1-3.

${ }^{56}$ Cf. Alfredo Guevara, Um sueño compartido, 2002.
} 
entre o que acontecia lá e o que começava a ocorrer por aqui, em nosso cinema. Tratava-se de uma forma de intercâmbio que poderia oferecer para Glauber uma inserção maior em outro universo de destaque; prova disso é sua declaração em carta: “Gostaria de escrever para Cine Cubano um artigo sobre o cinema brasileiro e seus problemas. Desta maneira, enquanto divulgamos no Brasil sobre o cinema de Cuba, os senhores divulgariam sobre nosso cinema, Caso seja de vosso interesse, espero que me escreva autorizando a remessa do artigo"57.

Dentro da ambiência local, percorrer sua correspondência de 1961 é um modo de examinar a manutenção de suas relações. Tudo isso talvez se torne mais importante na medida em que essas cartas retratem o grau de recepção e repercussão que seus textos ganhavam quando postos em circulação social pelos jornais. É o caso de uma carta recebida por Glauber e que foi enviada pelo então governador Juracy Magalhães. Note-se por um de seus trechos sua tonalidade:

"Fiquei ciente de seus comentários sob o título 'Inconsciência \& Inconseqüência da atual cultura baiana'.

Você é, com efeito, um jovem artista, independente, e sua inteligência e dedicação às cousas do espírito transparecem na obra que vem construindo. Possui, portanto, autoridade para emitir os juízos que publicou. Oportunos e justos.

Realmente, temos que realizar na Bahia, a todo custo, um trabalho de equipe que conduza àquele posto seu de realce.

Eu apenas sou um entusiasta e procuro realizar o que posso, para dar prestígio aos valores de nossa terra, em todos os campos.

$\mathrm{E}$ ao escrever-lhe estas palavras, ditadas pelo agradecimento ao generoso impulso que o fez citar-me entre os poucos que asseguram o renome da velha Província, penso que este será talvez um dos epitáfios que estou criando para mim mesmo: 'foi um homem que procurou ajudar a Bahia em todos os sentidos'.

Creia-me, pois, que nada me poderia ter sido mais grato do que ver estas intenções reconhecidas por um jovem do seu legítimo talento" ${ }^{58}$.

Mais do que a tentativa de inflar o ego do jovem autor, que já se mostrava com boa voz local naquele momento, evidência demonstrada na carta recebida do poderoso e ilustre local, o governador do estado baiano, a escrita de tal carta fora estimulada por um

\footnotetext{
${ }^{57}$ Glauber Rocha, Cartas ao mundo, 1997, p. 139. [carta de 03 mar. 1961, Salvador (BA), endereçada por Glauber a Alfredo Guevara].

${ }^{58}$ Glauber Rocha, Cartas ao mundo, 1997, p. 138. [carta de 10 fev. 1961, Salvador (BA), endereçada por Juracy Magalhães a Glauber].
} 
texto publicado cinco dias antes por Glauber, cujo destaque aos olhos do governador talvez tenha ficado por conta de uma pequena passagem: "o prestígio da terra vive por causa do governador JM, de Jorge Amado, Dorival Caymi e Marta Rocha. Graças a estes quatro nomes a Bahia não lidera o anedotário nacional..." ${ }^{59}$. É, no entanto, outras partes do artigo que parecem enveredar pela prática política mais intensa de Glauber no debate de idéias. Cabe compreendê-las mais de perto.

Em "Inconsciência \& inconseqüência da atual cultura baiana", de 5 de fevereiro de 1961, ele analisa nas páginas do Diário os motivos, o lugar e a presença da cultura baiana em perspectiva nacional. Para ele, se há um desprestígio naquele momento dos baianos em relação ao restante do país, é porque "existe um completo colonialismo cultural que se expressa, não por injunções complexas da vida pública, mas pela vida fácil que rege nossa produção local e sobretudo pelo clima indeciso que se estabelece entre duas gerações antagônicas que não se definem, movidas, ambas, por motivos gerais de sobrevivência: uma, ao que parece, depende da outra" ${ }^{60}$.

Vale, para Glauber, extrair as razões dessa situação. Uma situação que, em nível nacional, coloca o que poderia ser os melhores talentos da terra em segundo plano, tornandose a representação regional, conforme escreveu, sem lugar apropriado. Glauber pergunta: "De quem é a culpa?”. A resposta por ele dada estaria na própria situação local; trata-se de um arranjo que mais uma vez o jovem crítico focaliza o problema geracional posto em várias instâncias, desde o jornalismo diário até a crítica literária mais elaborada:

\begin{abstract}
"Verdadeiramente, sem abuso da palavra, a terra é província. Todavia, uma província que se liberta dia a dia, embora as constantes da moral classe-média permaneçam ativas em todos os setores da vida cultural. Assim, não possuindo colunista especializado de cultura, a não ser aqueles de cinema (e aí não estou puxando brasa para minha sardinha, pois ao menos temos uma 'associação'), o que resta na imprensa são alguns noticiaristas improvisados, autênticas comadres de interesses pessoais. Há uma geração nova de imprensa que reúne os nomes de Flávio Costa, Inácio Alencar, Ariovaldo Matos, Nelson de Araújo, adicionada por outra que lideram Florisvaldo Mattos, Paulo Gil Soares, Silvio Lamenha Lins, João Carlos Teixeira Gomes e José Contreiras, opõe-se uma mentalidade retrógrada do
\end{abstract}

\footnotetext{
${ }^{59}$ Glauber Rocha, "Inconsciência \& inconseqüência da atual cultura baiana", Diário de Notícias, Salvador (BA), 05 fev. 1961, p. 1.

${ }^{60}$ Glauber Rocha, "Inconsciência \& inconseqüência da atual cultura baiana", Diário de Notícias, Salvador (BA), 05 fev. 1961, p. 1.
} 
'colunismo lírico', da 'reportagem com fundo moral', do 'ditatorialismo bomconselho', do 'academismo enciumado' que, sobre todos os aspectos, entravam a propaganda baiana nos outros Estados, principalmente naqueles mais 'civilizados' de Rio e São Paulo"61.

Glauber parece pesar sobre a terra o ranço de uma suposta velha geração, cujos domínios da moral entravariam aquilo que a nova geração trazia de proposta, em termos de renovação intelectual. Razão que se explica seu ataque tão agudo, para não dizer agressivo. Como não podia ser de outro modo, o jovem crítico vê com bons olhos os encaminhamentos da sua própria geração, que, embora com algumas dissensões, como ele frisa, sempre esteve rodeada por uma responsabilidade cultural ímpar. Seu ataque avança para a parcela dessa velha geração justamente pela falta, segundo ele, dessa tal responsabilidade cultural.

Embora se possam supor suas intenções em tal empreitada, é preciso entender que sua polêmica passa por uma tentativa mais clara de uma cisão entre os mais novos e os mais velhos. Não deixa de ser curioso notar que Glauber tem uma nítida dimensão do funcionamento das relações estabelecidas no modelo de sociabilidade literária em terras baianas. Uma passagem do texto deixa mais claro este seu domínio: "Como, em toda comunidade capitalista, a vida da imprensa se mistura à vida literária, a segunda se vê fortemente prejudicada pelas manifestações de uma geração ultrapassada e violentamente invejosa dos novos vultos que surgem, inclusive, para mudar, de qualquer maneira, o estado de caos e inércia de nossa terra. O tom professoral, ainda admissível e respeitável, cedeu lugar ao tom da ora e da inveja, ao tom do gracejo contra a integridade humana, gracejo que se traduz, violentamente, na dúvida da masculinidade dos artistas modernos"62.

Dentro do confronto estabelecido, Glauber tinha que escolher algumas vias e a partir delas firmar suas opiniões. Não é por acaso que, como um caminho mais adequado de defesa, Glauber enxergue a necessidade de estabelecer um projeto de autonomia das atividades desses mais jovens artistas. Em outras palavras, a via da profissionalização do escritor em Salvador. Trata-se do estabelecimento da vida profissional do artista baiano como forma de se criar bases mais sólidas para um reconhecimento maior, sem as amarras do âmbito local. Deve-se reconhecer que os caminhos estavam mais delineados com a

\footnotetext{
${ }^{61}$ Glauber Rocha, "Inconsciência \& inconseqüência da atual cultura baiana", Diário de Notícias, Salvador (BA), 05 fev. 1961, p. 1.

${ }^{62}$ Glauber Rocha, "Inconsciência \& inconseqüência da atual cultura baiana", Diário de Notícias, Salvador (BA), 05 fev. 1961, p. 1.
} 
Universidade da Bahia, o estabelecimento do Museu de Arte Moderna e as portas abertas da própria Imprensa Oficial. Foram instituições que puderam, com todos os seus problemas, seus prós e contras, configurar um mínimo dessa primeira ação profissional tão falada, escrita e defendida por Glauber. Segundo seu ponto de vista, havia dentro do debate sobre esse primeiro sopro de profissionalização do artista as reações daqueles - incluindo parcela da juventude - que não resistiram ao "sacrifício do artista no trabalho criativo de todo dia" ${ }^{63}$. Ele escreveu sua ácida mensagem nas seguintes palavras:

"Diante das oportunidades os homens de verdadeira cultura e criação passaram a participar dessa nova era: eles foram os membros das gerações mais jovens, 'Caderno da Bahia' e 'Mapa' e outros veteranos que admitiram a 'bossa nova' com um sorriso nos lábios, compreendendo, devido à inteligência, o tempo e suas revoluções. Mas nestas próprias gerações, os talentos que mataram a juventude ainda na juventude não suportaram a transferência da ação para a contemplação e subitamente passaram de jovens a velhos e, como tais, se aliaram ao exército de quantos esperneiam nas colunas a dor da própria verdade que os cerca: aquela de não fazer nada e, sobretudo, possuir a inabalável certeza de que suas possibilidades intelectuais estão esgotadas e a eles, sem violência, só resta o suicídio do pensamento" ${ }^{\prime 4}$.

Das tais investidas desses que negavam o que Glauber denominava ser a "bossa nova” na cultura baiana surgiria, em sua concepção, uma espécie de inconstância social capaz de levar a um inconsequente estado de ânimos geral em relação ao futuro da cultura baiana, num efeito quase de degradação da atividade cultural local, que deixaria de ser reconhecida em qualquer espaço de atuação, fosse em Salvador ou fora dela. Para deixar de lado a pecha de "província", voltava a afirmar o jovem crítico, era preciso fazer o combate interno: "procuremos destruir de uma vez por todas as víboras locais" ${ }^{65}$. E entre suas idéias nada parecia melhor ajustado do que "reagir com trabalho" intelectual intenso: era preciso derrotar na província seu aspecto que mais ressaltava - a própria província.

\footnotetext{
${ }^{63}$ Glauber Rocha, "Inconsciência \& inconseqüência da atual cultura baiana", Diário de Notícias, Salvador (BA), 05 fev. 1961, p. 1.

${ }^{64}$ Glauber Rocha, "Inconsciência \& inconseqüência da atual cultura baiana", Diário de Notícias, Salvador (BA), 05 fev. 1961, p. 1.

${ }^{65}$ Glauber Rocha, "Inconsciência \& inconseqüência da atual cultura baiana", Diário de Notícias, Salvador (BA), 05 fev. 1961, p. 1.
} 
Demonstrando que o assunto não era impulso e rompante juvenil de crítico de um só artigo, a querela seria retomada meses depois, em mesma tonalidade e perspectiva. Em “Eis a fogueira, poeta!”, publicado no Diário em 28-29 de maio de 1961, Glauber faz uma nova leitura da situação de embate instituída entre seu grupo, boa parte de jovens, e o grupo já estabelecido, aqueles que detinham parte significativa da voz nos jornais da cidade. Neste seu novo encaminhamento de ideias, Glauber não poupa nomes. Faz parte de sua estratégia de embate analisar qual foi a ressonância do seu próprio pensamento antes divulgado. Com isso, o crítico legitima as próprias idéias colocadas em circulação dentro de um modelo de sociabilidade intelectual, que inclusive haviam sido aprovadas até pela força política local, representada pelo governador Juracy Magalhães. Ainda que não só isso. Glauber na mesma discussão procura esquentar outra polêmica: a força de seu argumento tornara-se impulso local, mesmo para intelectuais já de renome em Salvador, mostrando-se como um novo polo de discussão e repercussão da cultural local. Voltemos aos nomes disseminados no artigo.

Carlos Nelson Coutinho é o primeiro nome que o crítico cita. Coloca este personagem como "portador de uma atitude intelectual entusiasmante para sua própria geração. Trata-se, para o cineasta baiano, de um intelectual que surge, ao lado dos ficcionistas de 'Reunião', como uma das poucas figuras pensantes da Bahia atual”66. Glauber cai em elogios diante de um suposto ensaio deste jovem. Carlos Nelson Coutinho teria sistematizado aquilo que apenas ele próprio esboçara no seu artigo polêmico em fevereiro anterior. Vale para o jovem crítico baiano preencher as páginas do Diário com nomes que fizeram a plena repercussão de suas ideias. Veja-se, por exemplo, o caso do médico e professor Alicio Peltier de Queiroz, que é visto por Glauber não mais como um homem ilustre, mas como uma "das mais violentas revelações públicas já verificadas nesta cidade inquisitorial"67, cujo texto ganhou apoio do grupo de Glauber e reações da fração mais conservadora da elite local. Entre uma e outra forma de opinião, entre um e outro nome, importa para Glauber notabilizar seu próprio feito: a palavra "província" ganhou novos ares e, portanto, novo sentido, "pareceu nascer uma consciência de que era preciso arrancar a cidade deste peso denso dos valores mantidos pelas heranças de um passado que, na verdade, não encerra a menor glória" ${ }^{38}$. A província não mais está demarcada tão-somente pelo moralismo local, onde um texto sobre

\footnotetext{
${ }^{66}$ Glauber Rocha, "Eis a fogueira, poeta!”, Diário de Notícias, Salvador (BA), 28-29 maio 1961, p. 5.

${ }^{67}$ Glauber Rocha, "Eis a fogueira, poeta!", Diário de Notícias, Salvador (BA), 28-29 maio 1961, p. 5.

${ }^{68}$ Glauber Rocha, "Eis a fogueira, poeta!”, Diário de Notícias, Salvador (BA), 28-29 maio 1961, p. 5.
} 
"os problemas sexuais da mulher" e "considerações médicas sobre o tema da virgindade" (caso de Alicio Peltier de Queiroz) poderia ganhar repercussão indesejada. O oposto desta forma de pensamento poderia agora ser sentido. E Glauber fazia parte ativa deste oposto. Tal moral, que ele avaliou ser de base cristã e com esta foi bastante crítico, não poderia sob sua avaliação manifestar-se por condenações públicas com opiniões e depoimentos de "homens que estudam, pensam e procuram soluções” para várias instâncias da sociedade.

O discurso glauberiano, ao evocar a necessidade de romper com o passado em nível local, ganha uma ambição maior: a descoberta das próprias raízes nacionais para que o próprio povo brasileiro se descubra. Descobrir aquilo que ficou escondido em nome do desenvolvimento de uma "nobreza imitativa", disse ele. O jovem crítico do Diário parece oferecer as pistas para desvendar o anacronismo baiano daqueles tempos; numa chave de leitura possível, nada seria mais modernista do que este posicionamento seu: quebra com o passado em nome de uma nova configuração para os rumos da arte de então. A metáfora da raiz, e por consequência da terra (presente depois no seu já referido manifesto "Uma estética da fome"), é apresentada aqui como modo de chamar a atenção para a descoberta desses valores nacionais:

\begin{abstract}
"Digo, gente que precisa cavar as raízes, não aquelas deste ontem conservado em jarros de pudicícia, mas outras, por mais distantes que estejam, existentes na residência de nosso povo dentro da paisagem, das quais poderemos encontrar uma epopéia e nela o sangue de pelo menos duas raças ricas, principalmente a negra, de cuja fonte vem a nossa representação cultural”' ${ }^{39}$.
\end{abstract}

Mais uma vez, o jovem crítico está disposto a analisar as causas e consequências da atual situação baiana, cuja "covardia mental" é destacada por ele como a pior de todas as causas. Sob sua concepção, Glauber coloca a exata situação de seu grupo: "somos presas de nossas mais íntimas necessidades e falar custa caro, arrisca o autor ao desemprego, à calúnia pública, à ofensiva pessoal e até mesmo à expulsão da cidade. Se nos jornais instalam-se alguns débeis escribas, dotados de um lirismo demagogicamente cristão, de um lirismo que é a própria fisionomia da cidade centenária, nos antigos casarões destes nobres enferrujados habita a decadência moral vestida de um pudor altivo, falante. E quando menos o homem que fala espera, o circuito está fechado, às vezes atacam, a democracia vira piada

\footnotetext{
${ }^{69}$ Glauber Rocha, "Eis a fogueira, poeta!", Diário de Notícias, Salvador (BA), 28-29 maio 1961, p. 5.
} 
constitucional. A língua pode ser cortada e até o pão corre o risco de desaparecer. Divirto-me, contudo. Aqui repito coisas ditas no outro artigo e foi perigoso o risco corrido"70.

Os exemplos e assuntos polêmicos continuavam a aparecer nas páginas do Diário pelas mãos de Glauber. Meses depois de intensa mobilização, ele novamente enfrentaria uma discussão sobre o papel dos escritores e artistas da mais nova geração e os supostos feitos desses novos intelectuais no campo intelectual e artístico baiano. Prestes a deixar sua função no jornal, lugar que dali em diante seria ocupado pelo amigo Paulo Gil, seu texto ganhava os ares de despedida. Demarcava-se no artigo o seu registro consciente do que aconteceu nos anos de sua luta baiana, o que o levava, ao final, a clamar por um compromisso - dele e de seus leitores. Um último compromisso de empenho de sua geração e quem mais estivesse favorável: "não deixar que a cidade durma"71.

O que isso poderia significar?

A resposta não é das mais fáceis. Talvez se possa resumir pela máxima invocada pelo próprio crítico nesse seu artigo-despedida: "só jogando as lanças o pensamento pode articular para o futuro" ${ }^{72}$. Restava saber de onde vinham essas tais lanças e o que e quem ela poderia atingir, e com que propósitos.

Publicado em 18-19 de junho de 1961, "Sobre 'ângulos' \& outros bichos” é um artigo em que ele reelabora os preceitos dos seus textos anteriores sobre os jovens intelectuais baianos e as instituições de impulso mobilizador da cidade. Neste, Glauber fecha pontos de vistas, traz outros à tona, mostra-se, enfim, um crítico motivado com os problemas locais da literatura e das outras artes. Mais do que motivado, mostrara-se um crítico otimista com os rumos que a cultura baiana do momento tomava. O tom é de despedida e mais uma vez estava em jogo a defesa da forma de pensamento independente e autônoma como projeto para a nova geração dentro do campo cultural local. Vejamos.

Começa seu texto levantando um suposto problema para uma abordagem inicial: escrever um artigo sobre as dificuldades e problemas que o jovem escritor, desconhecido dos meios editoriais, enfrenta. A ideia - por sinal, já debatida em seus artigos anteriores - logo é colocada de lado. Em seu lugar, eis que surge um novo empenho em defender as transformações ocorridas na vida cultural baiana daquele início de década. É também um

\footnotetext{
${ }^{70}$ Glauber Rocha, “Eis a fogueira, poeta!”, Diário de Notícias, Salvador (BA), 28-29 maio 1961, p. 5.

${ }^{71}$ Glauber Rocha, “Sobre 'ângulos' \& outros bichos”, Diário de Notícias, Salvador (BA), 18-19 jun. 1961, p. 5.

${ }^{72}$ Glauber Rocha, "Sobre 'ângulos' \& outros bichos”, Diário de Notícias, Salvador (BA), 18-19 jun. 1961, p. 5.
} 
artigo em que o crítico faz uma pequena despedida de seus leitores: é o momento de partida, junto com Roberto Pires, para "aprontar filmes" no Rio de Janeiro. E é pensando talvez nessa despedida que Glauber deixa sua marca. Tal como ocorrera em outros artigos, é preciso falar da Bahia, do que houve até aquele momento, e, claro, salientar sua participação e do seu grupo. Fazer certo balanço e incluir-se nele.

O ano de 1961, em sua concepção, é um ano de bons resultados ou como ele mesmo disse "é um bom ano cultural". É evidente que Glauber vai frisar o papel de seu grupo, a agitação por eles alcançada, os novos nomes e as instituições presentes na cena soteropolitana daquele ano. O rol dos companheiros é grande, entre os mais jovens e os veteranos: Paulo Gil, o homem de boas peças, Florisvaldo Mattos, com seu "genial 'Reverdor'”, o romancista Nelson de Araújo, os artistas plásticos Mario Cravo Jr., Jenner Augusto, Calazans Neto. No caso das instituições e os veículos de comunicação do grupo, veja-se o exemplário: Ângulos, que "traz em suas páginas a melhor ensaística jovem e velha, a melhor literatura e a melhor poesia da Bahia"; a IOB, a editora da Universidade da Bahia, que, sob a coordenação do professor Milton Santos, ofereceu a Nelson de Araújo as condições profissionais para que pudesse organizar coleção literária e de revista; é o MAMB e sua atividade, entre outros. Se este texto pode ser compreendido como o registro da sua despedida - mesmo que momentânea, dado que Glauber ainda voltaria com boas contribuições ao periódico -, o jovem crítico sabe que é preciso demarcar para um grande público as realizações para a construção de uma nova presença intelectual na dinâmica cultural baiana. Razão que se mostra mais explícita no elenco de pessoas e instituições culturais. Destes é preciso falar, sabe Glauber. Afinal, conseguiram enfrentar o localismo da arte baiana. E falar deles, no fundo é fazer que sua trajetória se torne mais presente, além dos burburinhos da Rua Chile.

\section{O espaço do Suplemento Artes e Letras e a gênese para um manifesto}

Como já foi dito, o ano de 1961 foi para Glauber um período de intensas colaborações no Diário de Notícias. Repetia certas atitudes antes vistas no Jornal da Bahia, embora com certas especificidades. Já mais experiente, o jovem crítico esteve nessa nova 
ocasião impulsionado a fazer frente ao localismo da arte baiana com textos em que analisava com mais propriedade e elementos os feitos de seu grupo e as condições de produção e difusão no circuito artístico de Salvador. Geralmente, nas páginas deste suplemento do Diário, Glauber chamava a atenção do seu leitor para as últimas novidades de seus jovens companheiros, retratando, em qualquer brecha disponível, as penúrias de novatos artistas com quase ou sem nenhuma chance de se lançarem num universo de intensa competição com os mais bem estabelecidos.

Notem-se dois textos modelares a seguir.

Um deles, publicado nos últimos dias de 1960 - portanto, quase fechando $1960 \mathrm{e}$, ao mesmo tempo, abrindo o ano de 1961; o outro, publicado no último dia do ano de 1961 portanto, fechando o ano de 1961 e, literalmente, abrindo a mensagem de um novo ano para 1962. É interessante notá-los nessa perspectiva de tempo, como textos que balizam suas ideias, sob a forma do manifesto, fazendo críticas e exigências dentro do seu espaço social de atuação. Embora materializados sob o intervalo de um ano aproximado, é preciso ainda observá-los como figurações mútuas de um mesmo valor divulgado. Ideias, por assim dizer, que se entrelaçam para a mesma manifestação dentro do campo cultural. Vejamos.

O artigo "Experiência 'Barravento': confissão sem moldura”, de 25-26 de dezembro de 1960, sob um plano mais geral, é o relato de Glauber das exigências e dificuldades em se executar um filme independente no Brasil; segundo suas palavras "um ato de coragem"73. Ainda no plano analítico da situação a qual sobrevive o cineasta no Brasil, o jovem crítico vai comparar tal atuação artística com as demais, sublinhando sua principal diferença. Se "a frase literária, o verso, a cor da pintura, a composição musical colocam o autor apenas diante do problema intelectual" ${ }^{74}$, no cinema a questão parece se configurar de outro modo: nele, o "autor enfrenta a técnica, a economia, a arte" ${ }^{75}$. Sob esta perspectiva, em nenhuma outra arte o realizador estaria tão submisso aos problemas econômicos como no cinema. Em outras palavras: diferente de outros produtores de arte, o cineasta poderia comprometer o valor de seu objeto artístico por conta dos aspectos econômicos.

\footnotetext{
${ }^{73}$ Glauber Rocha, "Experiência 'Barravento': confissão sem moldura”, Diário de Notícias, Salvador (BA), 25-26 dez. 1960, p. 6.

${ }^{74}$ Glauber Rocha, "Experiência 'Barravento': confissão sem moldura”, Diário de Notícias, Salvador (BA), 25-26 dez. 1960, p. 6.

${ }^{75}$ Glauber Rocha, “Experiência 'Barravento': confissão sem moldura”, Diário de Notícias, Salvador (BA), 25-26 dez. 1960, p. 6.
} 
Refletindo numa possível saída para este dilema econômico e tendo já a vivência da produção e a experiência de direção em Barravento, Glauber reverteu o ponto de vista sobre o cinema-arte, em seu sentido mais restrito e de autonomia:

\begin{abstract}
“O filme hoje não pode ser 'arte'. Uma experiência muda o homem mais do que milhões de teorias ou tempo infinito gasto nos estudos. Compreendemos subitamente a dura realidade do subdesenvolvimento nacional. E que a crise do cinema é associada e conseqüente da crise geral de fome que nos envolve. Por isto, em tese, o filme não pode ser 'arte'. Tem que ser manifesto. É através destes manifestos que estaremos contribuindo para a melhoria radical do país e, por força, do próprio cinema. Somente um clima de paz pode gerar a poesia pura que muitos homens estabelecidos procuram. Não podemos fugir da fome evidente que grita a quatro ventos, saindo uníssona das pobres gargantas infantis. No princípio é uma revolta sem precedentes. Depois a lógica e em seguida a disposição para a coragem"76.
\end{abstract}

Se lá atrás, como já notei, quando crítico do Jornal da Bahia e analista do fenômeno cinematográfico em Angulos, é possível dizer que Glauber havia defendido um princípio mais purista para a arte do cinema, aqui, no final de 1960, sua posição prioriza um novo horizonte. Parece estar mais demarcada pelo princípio de uma arte que estivesse comprometida com os problemas sociais da terra. À primeira vista, o peso para um dos lados da balança talvez se explique pelo contato diário com as filmagens de Barravento, filme que, por conflitos internos de produção, é obrigado a assumir o lugar de Luiz Paulino dos Santos. Suas palavras justificam tal compromisso e enfrentamento: "confesso que, a cada dia que marchava para a colônia de pescadores, descobria a política”. O jovem crítico estabelecia uma tensão entre dois polos de defesa da arte do cinema - a luta entre a poesia e o manifesto. A esta tensão estaria ligada certa pergunta: haveria poesia onde há fome? O lado capcioso da pergunta, com ares de dilema, pode acobertar uma raiz do problema: não estaria Glauber, em sua forma de manifesto e aderência ao cinema como modo comprometido de enunciar os problemas e as reflexões da terra, propalando a defesa solene de um novo imaginário social, visto sob os aspectos de uma consciência interna e nacional-desenvolvimentista, portanto menos vislumbrada ao exemplo de fora?

\footnotetext{
${ }^{76}$ Glauber Rocha, "Experiência 'Barravento': confissão sem moldura”, Diário de Notícias, Salvador (BA), 25-26 dez. 1960, p. 6.
} 
A resposta deve ser encarada dentro do mundo de contradições que Glauber enfrentava. No horizonte de recepções do jovem crítico, não se pode esquecer o provável impacto que o texto "Uma situação colonial?", de Paulo Emílio, possa ter gerado, alimentando muitas ideias presentes nos seus artigos do Diário. Tais evidências são significativas e não devem ser desprezadas. Publicado em 19 de novembro de 1960, no Suplemento Literário do jornal O Estado de S. Paulo, o artigo do crítico paulista obteve ampla circulação e repercussão na comunidade de críticos de cinema, dado que sua primeira versão foi divulgada na Primeira Convenção Nacional da Crítica Cinematográfica, que aconteceu em São Paulo. Mesmo que Glauber não estivesse no evento por conta dos compromissos com a filmagem de Barravento (fato elucidado por troca de cartas $^{77}$ entre o crítico baiano e o crítico paulista e por $\operatorname{artigo~}^{78}$ deste último em que ele relata os acontecimentos da convenção), sua presença, no entanto, fora demarcada de outras maneiras e é bem possível que as teses enunciadas no evento por Paulo Emílio tenham caído nas mãos de Glauber ainda em jornal do dia.

Já o que vale mesmo nesta comparação é a força das ideias entre um e outro artigo de cada um dos críticos, isto é, seus pontos de contato, convém explicitá-los. A força do texto de Paulo Emílio, como bem observou Roberto Schwarz ${ }^{79}$, está em resumir um estado de ânimo presente à época: tratava-se de explicitar a perspectiva dentro do campo da cultura a qual o nacional-desenvolvimentismo queria superar. A linha assumida por Glauber no artigo não é muito diferente desta. Muito pelo contrário. Note-se que o jovem crítico está sempre a presumir um movimento de superação em direção a um novo estado do campo cultural. Neste sentido, o cinema é uma das ramificações fortes neste campo cultural e talvez o que melhor assumia sua aspiração de rompimento com o tradicionalismo por conta de sua componente industrial.

Em perspectiva local, já falando em plena sintonia com uma esquerda nacional cada vez mais crente na viabilidade de um projeto de nacionalismo e de desenvolvimento, Glauber está em manifesto com uma realidade presente para o público e os realizadores do cinema brasileiro. Trata-se de deixar às claras a descrença de ambos - público e realizador -,

\footnotetext{
${ }^{77}$ Cf. Glauber Rocha, Cartas ao mundo, 1997, pp. 124-128; pp. 130-131. [carta de 02 nov. 1960, Salvador (BA), endereçada por Glauber a Paulo Emílio; carta de 19 nov. 1960, São Paulo (SP), endereçada por Paulo Emílio a Glauber].

${ }^{78}$ Cf. Paulo Emílio Salles Gomes, "Fisionomia da Primeira Convenção", em Crítica de cinema no Suplemento Literário (V. 2), 1982, p. 295. [O Estado de S. Paulo, 19 nov. 1960].

${ }^{79}$ Cf. Roberto Schwarz, "Fim de século", em Seqüências brasileiras, 1999, pp. 155-156.
} 
para quem o filme brasileiro jamais alcançaria o nível do cinema de fora, questão a qual Paulo Emílio chamou de "marca cruel do subdesenvolvimento" ${ }^{80}$. Nesse círculo de interação entre público e realizador, dentro de uma prática caracterizada pelo subdesenvolvimento, o cinema brasileiro estaria fadado à cópia servil, sempre alimentado por uma situação externa, parâmetro que desarma qualquer tentativa mais ambiciosa. Trata-se de um ponto de contato com o crítico paulista: Paulo Emílio salientou que se o realizador produzir determinado gênero de filmes que ele mesmo despreza, ele alega "ser o único tipo de cinema brasileiro que o público aceita" ${ }^{\prime 1}$.

O que Glauber faz em seu artigo é chamar a atenção para o problema e apresentálo em outra chave de interpretação complementar ao que foi exposto por Paulo Emílio. Pela própria experiência de realizador, junto à sua prática de crítico cultural, quer demonstrar a viabilidade do projeto de realização local para o influxo fecundo do novo cinema brasileiro independente. Segundo suas próprias constatações, Rio, quarenta graus, de Nelson Pereira dos Santos, havia sido o seu marco de autenticidade, quando se abriu "o coração do povo para o filme" ${ }^{\$ 2}$, momento da "integração social" pelo cinema. O passo seguinte Glauber guardava para si mesmo, com a execução de Barravento, um filme que "pretende o público internacional" $" 83$.

Pela via de Barravento, o jovem crítico busca mostrar que o negro do cinema brasileiro não deve ser encarado como paisagem exótica da miséria. Nesse novo eixo da reorganização do lugar da imaginação, o pensamento intelectual volta-se à própria terra e negro pobre, nessa nova chave, é encarado como forma precária da vida nacional que deve ser inserido no universo do desenvolvimento e da modernização. Por isso, Glauber vai dizer:

"O que primeiro precisamos tentar é dar ao negro consciência desta miséria e talvez acentuá-la o mais possível, como se acua um gato num beco. Foi assim que Fidel agiu com os camponeses cubanos. O tumor explodiu.

\footnotetext{
${ }^{80}$ Cf. Paulo Emílio Salles Gomes, "Uma situação colonial?", em Crítica de cinema no Suplemento Literário (V. 2), 1982, p. 286. [O Estado de S. Paulo, 19 nov. 1960].

${ }^{81}$ Cf. Paulo Emílio Salles Gomes, "Uma situação colonial?", em Crítica de cinema no Suplemento Literário (V. 2), 1982, p. 287. [O Estado de S. Paulo, 19 nov. 1960].

${ }^{82}$ Glauber Rocha, "Experiência 'Barravento': confissão sem moldura", Diário de Notícias, Salvador (BA), 25-26 dez. 1960, p. 6.

${ }^{83}$ Glauber Rocha, "Experiência 'Barravento': confissão sem moldura”, Diário de Notícias, Salvador (BA), 25-26 dez. 1960, p. 6.
} 
A tese da covardia, da fraqueza e do servilismo dos pobres brasileiros está corretíssima. Precisamos torná-los cientes do que são. Ter pena do pobre é estar enquadrado no campo do serviço social"»4.

A defesa do negro no cinema e, ao mesmo tempo, a defesa do cinema nacional, como um projeto estético próprio, por assim dizer, traz em si um duplo passo para Glauber, que o coloca, naquele momento, no mesmo campo de ação de outros intelectuais de esquerda de época. No âmago dessa consciência crítica, estava o reconhecimento que partes de um mesmo problema eram a "exploração de classe interna e as grandes desigualdades na ordem internacional” ${ }^{85}$. Em relação à primeira parte desse conjunto formado, a exploração interna, o jovem crítico se indispunha dizendo, em tom de denúncia, que conhecia "comunistas e sociólogos que masturbam a 'realidade operária' como profissão e têm ao mesmo tempo violento pavor de tudo que seja mendicância" ${ }^{86}$. Em relação à situação externa, Glauber procura envolver-se na resposta com a sua própria realização. Nesse sentido, Barravento, que, segundo ele, poderia ter sido configurado como um "poema do mar, coqueiros, auroras e exotismo" ${ }^{\text {" }}$, ganha sua versão de "fotografia da miséria", impulsionada, claro, pelo alento de uma ideia de desenvolvimento que alcançava com vigor várias frações intelectuais.

O artigo "Luz Atlântica, 1962", escrito depois de um ano, em 31 de dezembro de 1961, vem completar as ideias presentes no artigo-manifesto sobre Barravento. Começo por citar uma frase que talvez sintetize a ordem de problemas presentes no texto: "a beleza tem de ser exilada da história, enquanto permanecer a cúpula da injustiça" ${ }^{\text {. }}$. A presente frase, embora possa, à primeira vista, parecer de forte teor cifrado, com certeza, tem sua verificação mais justa ao refletir sobre sua própria condição de produção e o seu contexto de inserção. A separação entre a beleza - tomada aqui de empréstimo do que há, via tradição idealista, de mais poético - e o que é o seu dado mais político e histórico, dentro dessa concepção de Glauber, só ocorre por conta da sua condição de existência subdesenvolvida. É a situação subdesenvolvida que não permite a arte pura, mas, sim, sua versão mais engajada. Em trecho

\footnotetext{
${ }^{84}$ Glauber Rocha, "Experiência 'Barravento': confissão sem moldura”, Diário de Notícias, Salvador (BA), 25-26 dez. 1960, p. 6.

${ }^{85}$ Cf. Roberto Schwarz, "Fim de século", em Seqüências brasileiras, 1999, p. 157.

${ }^{86}$ Glauber Rocha, "Experiência 'Barravento’: confissão sem moldura”, Diário de Notícias, Salvador (BA), 25-26 dez. 1960 , p. 6.

${ }^{87}$ Glauber Rocha, "Experiência 'Barravento': confissão sem moldura”, Diário de Notícias, Salvador (BA), 25-26 dez. 1960, p. 6.

${ }^{88}$ Glauber Rocha, "Luz Atlântica, 1962”, Diário de Notícias, Salvador (BA), 31 dez. 1961, s/p.
} 
mais à frente ele diria o seguinte: "As novas gerações do Brasil não esperam continuar uma arte e um pensamento para divertir e justificar a estabilidade da superestrutura" ${ }^{\text {}}$.

Tal idéia não é exclusividade de Glauber e pode ser encarada como emblema de parcela barulhenta de intelectuais do momento. A lista de teóricos, intelectuais e artistas latino-americanos que compartilham uma visão bastante próxima não é das menores. Só para ficar em dois nomes e nas suas ideias divulgadas, cito um exemplo nosso e um de fora: do já aqui falado Paulo Emílio, veja-se a versão original do texto “Uma situação colonial?” que, conforme havia colocado, foi lido na Primeira Convenção Nacional da Crítica Cinematográfica, que deu origem ao seu artigo homônimo publicado no Suplemento Literário d' O Estado de S. Paulo; ao final deste referido artigo o autor elenca uma série de conclusões (suprimidas do artigo impresso em jornal), que aqui valem por registrarem de modo mais explícito suas ideias em torno das relações entre o campo estético e o campo de atuação crítica engajada no mundo subdesenvolvido: "É dever da crítica brasileira familiarizar-se com os problemas econômicos e legislativos da cinematografia brasileira, e participar do esforço para resolvê-los [...] Participando desse movimento de soberania, a crítica cinematográfica brasileira contribuirá para fazer secar as fontes de sua alienação e operará a própria transcendência a um nível superior de integração e desenvolvimento" "90; de fora do Brasil, um dos exemplos mais significativos, entre outros, é do crítico uruguaio Ángel Rama, cujo artigo "Nossa América”, publicado no semanário Marcha, de Montevidéu, de 29 de dezembro de 1961, é demonstração do compasso de ideias presentes tanto aqui como lá: "Mas a agitação que hoje comove a América Latina não se resolverá com uma mudança suave. Muitos valores falsos deverão ser definitivamente banidos. Isso não será fácil, mas é necessário para estabelecer as diferentes bases civilizadoras, trabalho no qual concorre uma tradição sustentada por grandes artistas e pensadores" ${ }^{\prime 1}$. A estes dois exemplos, juntar-se-iam mais inúmeros outros. Participavam, todos eles, de um clima de mudança em que variada fração de intelectuais voltava-se para o engajamento com vistas à superação da situação subdesenvolvida, demonstrando ser a arte pura, sem sua via mais política, um projeto incompatível naquele momento.

\footnotetext{
${ }^{89}$ Glauber Rocha, "Luz Atlântica, 1962", Diário de Notícias, Salvador (BA), 31 dez. 1961, s/p.

${ }^{90}$ Paulo Emílio de Salles Gomes, "Uma situação colonial?", s/p. [material datiloscrito, Cinemateca Brasileira, São Paulo (SP)].

${ }^{91}$ Ángel Rama, "Nossa América”, em Literatura, cultura e sociedade na América Latina, 2008. p. 63.
} 
No compasso dessas ideias, o caso de Glauber é notório. É jovem dentro do campo e sua aposta, como se verificam nesses e em outros artigos está baseada em demonstrar uma atitude de rompimento com a norma de produção vigente, apostando numa mudança externa e política em curso e numa nova leva de consumidores que assegurariam o sucesso de suas produções. Dito e feito. Seu primeiro filme, Barravento, assume o ônus da empreitada. E talvez estar na boca de críticos consagrados como Paulo Emílio e Walter da Silveira, ser amplamente coberto pela imprensa baiana, tendo ele, o próprio Glauber, um espaço para o comentário e o manifesto em torno da sua realização artística, são fatores que levam a crer que sua estratégia era de fato bem sucedida, mostrando que o ônus da empreitada havia gerado um bônus considerável em termos de resultados.

"Luz Atlântica, 1962" seguia também como aposta ousada, dada sua tentativa de síntese e defesa manifesta de uma geração menos literária e mais política. Glauber quer provar para seu leitor que sua geração já transformou o campo cultural por uma ruptura com os estabelecidos. Isso talvez seja um dos indicativos para sugerir que o seu artigo esteja mais próximo do tom e da perspectiva de um gênero de manifesto. Explico melhor. Nessa exposição de valores e ideias o jovem crítico cria uma estratégia. Consiste em inventariar nossas rupturas culturais do passado, para em seguida elencar a própria ruptura de sua fração intelectual.

Antes de começar analisar o seu próprio tempo, a identificação do passado é assim disposta: 1922 é o tempo de "ruptura com academicismo e o lançamento de uma quase anarquia para construção de nova linguagem nacional" 1930 é o "grito de um romance que trazia as raízes da terra em seu contexto" ${ }^{93}, 1945$ tratou de ser o "pensamento desesperado que organizou formalmente o caos de 22 "94. Listar períodos bastante significativos de nossa história cultural, levando-se em conta, sobretudo, nossa vida literária, e dispô-los como períodos antecedentes à própria história que se formava ali desde então, a qual, por sinal, um dos personagens principais seria ele próprio, foi um dos modos que o jovem crítico encontrou para o manifesto das ideias políticas, por assim dizer, de uma nova geração em curso. Seus exemplos trazidos no corpo do artigo confirmam este caráter de manifesto de geração. Dentre estes, destaca-se o teatro paulista, com "garotos da pequena burguesia" que

\footnotetext{
${ }^{92}$ Glauber Rocha, "Luz Atlântica, 1962”, Diário de Notícias, Salvador (BA), 31 dez. 1961, s/p.

${ }^{93}$ Glauber Rocha, "Luz Atlântica, 1962", Diário de Notícias, Salvador (BA), 31 dez. 1961, s/p.

${ }^{94}$ Glauber Rocha, "Luz Atlântica, 1962", Diário de Notícias, Salvador (BA), 31 dez. 1961, s/p.
} 
levavam um novo drama social ao público: "os diretores Flavio Rangel \& Antunes Filho e os autores Augusto Boal, Gianfrancesco Guarnieri e Oduvaldo Viana Filho romperam com o teatro impressionista e burguês para, purificados dos crimes da estética, falar a linguagem da verdade no único estilo capaz de comunicar sem trapaças" ${ }^{\text {95 }}$. É notável os últimos termos utilizados na frase. "Comunicar sem trapaças" ganha o significado de não deixar que certo lirismo tome conta daquilo que talvez, dentro dessa concepção, seja o que realmente é válido: escancarar a nossa situação colonial. Se o teatro foi uma das molduras que a nova geração política pode se manifestar, não foi só dele que ela se utilizou. Segundo Glauber, tratava-se do "nascimento da juventude universitária”, crente no cinema e na imprensa também. Uma juventude de "estudantes fizeram do pensamento ponte de ação e não delírio romântico do consagrado intelectual brasileiro" ${ }^{96}$.

O ano de 1962 surgia com um horizonte auspicioso para Glauber, misto de "esperança e desespero". Esperança, porque havia a confiança em superar, no plano da ação política, a classe dirigente e havia a certeza de que os novos valores substituiriam os velhos e ultrapassados valores dessa mesma classe. O desespero vem por conta da própria necessidade premente dessas modificações desejadas no plano político; sob a metáfora mais uma vez da terra, ele vai dizer "que há um desespero na terra, cujo nome veladamente é Fome" ${ }^{\text {97 }}$. A concepção glauberiana desse desespero e esperança faz uma representação de tal situação, trazendo para si a responsabilidade de clamar pelo engajamento da própria geração intelectual, cujas palavras ganham destaque pelo seu impulso de manifesto e agendamento de valores políticos para a intervenção mais ampla no universo estético, como se pode atestar:

"E que, no resultado da insegurança, vozes de uma geração já saem do sussuro e do meditar solitário para dar à Palavra a força indestrutível que ela carrega em si, desde quando esteja insuflada pela dignidade e pelo justo protesto do homem revoltado. Então, como pode o intelectual brasileiro (mesmo aquele que é dos quarentanos e já se encontra violentado pelo triunfo da Injustiça) pensar na Musa e na Cor se hoje, mais do que nunca na história deste país, a criação está sendo exigida como arma e não como fim de dramáticas existenciais? Que melhor destino poderia ter a inteligência brasileira, que nos é rica de belas tradições, mas

\footnotetext{
${ }^{95}$ Glauber Rocha, "Luz Atlântica, 1962", Diário de Notícias, Salvador (BA), 31 dez. 1961, s/p.

${ }^{96}$ Glauber Rocha, "Luz Atlântica, 1962", Diário de Notícias, Salvador (BA), 31 dez. 1961, s/p.

${ }^{97}$ Glauber Rocha, "Luz Atlântica, 1962", Diário de Notícias, Salvador (BA), 31 dez. 1961, s/p.
} 
equivocada pelos mitos criados para a desesperada justificativa da mediocridade?" ${ }^{\prime 98}$.

Resolvi fechar este capítulo, de sua fase profissional na imprensa baiana, com os comentários desses dois artigos - "Experiência 'Barravento': confissão sem moldura” e "Luz Atlântica, 1962" - por achar que ali, em ambos, já se reúnem uma motivação do jovem crítico (aliás, já jovem cineasta) pela forma do manifesto. Seu objetivo é refletir sobre o objeto artístico em sua conexão com a vida social precária, característica da ordem subdesenvolvida.

Os respectivos artigos representariam não só desdobramentos ou reafirmações de ideias apresentadas ainda em sua fase mais juvenil, fase das contribuições em Mapa e Ângulos, mas também uma maior aderência a um projeto de ordem mais nacional e geral. Um projeto ambicioso que nas suas bases estava previsto também a discussão das formas de desenvolvimento do país. Um novo emblema para um novo imaginário social.

$\mathrm{Na}$ ordem pessoal, pode-se pensar que talvez ainda seja possível detectar nestes dois textos a gênese de um projeto individual e ambicioso, como disse antes, com os pés na Bahia, mas os olhos no Rio. Até mesmo porque, neste final de anos 1950 e início dos anos 1960, ele já fazia, em concomitância, tanto contribuições em periódicos da Bahia, como no Rio por meio do Jornal do Brasil. Neste seu projeto pessoal, havia uma premissa para que pudesse encontrar campo de irradiação e de aceitação adequados: precisava encontrar no discurso do desenvolvimento nacional o elemento central para se organizar a prática artística da nova geração. Foi assim que Barravento, como ressaltava Glauber, longe de ser presidido por uma utópica perspectiva de lirismo, consegue se manter como produto simbólico justo para aquela parcela intelectual que acreditava ser a via do desenvolvimento o caminho mais justo também para a arte. Em contrapartida, a nova geração encontrava aberta a porta para um novo mercado de bens simbólicos. Restava a Glauber, como missão pessoal e projeto coletivo de grupo, realocar sua trajetória em perspectiva menos local. Antes de deixar a Bahia, o Rio de Janeiro já o esperava.

\footnotetext{
${ }^{98}$ Glauber Rocha, "Luz Atlântica, 1962", Diário de Notícias, Salvador (BA), 31 dez. 1961, s/p.
} 


\section{A prática do ensaio de ideias e a confirmação da consagração}

Estou em luta com muita gente. Vou terminar dando tiro no Rio e São Paulo. Você sabe que tenho sangue de cangaceiro.

Glauber Rocha, em carta a Paulo César Saraceni [Rio de Janeiro, 1961]

\section{De Salvador ao Rio de Janeiro: as formulações intelectuais e as práticas de consagração pelo Jornal do Brasil}

As memórias de Paulo César Saraceni ${ }^{1}$ são um precioso documento da movimentação dos jovens do Cinema Novo, pois, antes de qualquer coisa, fornecem uma ambiência da amizade com o então desconhecido Glauber e o flerte deste com os locais cariocas. O jovem baiano iniciara suas viagens ao Rio de Janeiro ainda em fins do decênio de 1950, em concomitância às suas atividades de crítico nos jornais baianos e às suas primeiras realizações como cineasta, jovem cineasta.

Em 1959, ambos, Saraceni e Glauber, finalizavam seus primeiros curtasmetragens e o ponto de encontro deles passou a ser os corredores da famosa Líder Laboratórios, na rua Álvaro Ramos, no bairro de Botafogo. Saraceni conta que a primeira vez que encontrou Glauber no Rio de Janeiro, época quando ainda não tinha sequer ouvido falar do jovem baiano, foi por intermédio de Miguel Borges e Carlos Pérez num encontro no famoso bar Alcazar. Na mesma ocasião, Glauber apresentou-se como cineasta baiano, pedindo-lhe o telefone para um posterior contato, o que não demorou. Já no dia seguinte,

\footnotetext{
${ }^{1}$ Cf. Paulo César Saraceni, Por dentro do cinema, 1993.
} 
Saraceni receberia seu telefonema com o propósito de marcar o primeiro encontro daquilo que se tornaria uma efetiva amizade nos anos seguintes. Uma significativa e simbólica amizade no círculo do Cinema Novo. Desse registro, é interessante notar a figura constituída por Saraceni em relação a Glauber, saldo, saliente-se, das memórias já embargadas e enformadas pela silenciosa marca roedora do tempo:

"[...] disse que queria ser meu amigo, que eu era o único que tinha feito um filme, tinha dado, como ele, o salto da teoria para a prática. Gostei, fui ao encontro de Glauber, nos tornamos grandes amigos. Os dois filmes, o meu e o dele, estavam montando o negativo com o Sousa, que tinha uma moviola $16 \mathrm{~mm}$, numa vila ao lado da Líder em Botafogo. Começamos juntos a freqüentar o bar em frente à Líder, que era um botequim com ótimo chope, e trocamos muitas idéias e confidências. Eu via Glauber todos os dias, e estava espantado e surpreendido. Baiano do sertão, meio Riobaldo, meio Diadorim, de Vitória da Conquista, e sabia tudo. Radical e violento na sua revolução, que era doce e brasileira. Protestante, contestava a sociedade e o regime com vigor, e bom caráter. Tinha idéias geniais”².

Em meio aos prováveis lapsos de lembranças do autor de Porto das Caixas nessa sua rememoração de Glauber, o traço, sem sombra de dúvida, mais marcante é o jovem que vem de longe para iniciar sua amizade sob os laços de um projeto intelectual comum. Não é à toa que esses primeiros encontros de Glauber sempre guardam o seu lado insistente em mostrar-se integrante de um mundo intelectual compartilhado: em pauta, é a onda de fazer um filme e o vigor de participar e topar quaisquer discussões teóricas em torno da nova arte. Quem estivesse na mesma via, Glauber demonstrava apreço, pontapé inicial para uma amizade que poderia ser duradoura ou não, a depender dos desdobramentos. Talvez fosse por esse modo prático, escolhendo seu correspondente intelectual a partir de suas ações de visibilidade na capital carioca e já empreendendo o fino trato da amizade, que ele tenha encontrado uma maneira mais profícua de se estabelecer num primeiro momento naquilo que lhe parecia alheio, embora muito sedutor: o Rio de Janeiro. Nessa maneira de estreitar vínculos, cuja sua atividade de escritor contumaz de cartas o auxiliou na forma de manutenção quando estivesse longe, é que se deu o contato com o grupo de Reynaldo Jardim, que coordenava as páginas do Suplemento Dominical do Jornal do Brasil (SDJB).

\footnotetext{
${ }^{2}$ Paulo César Saraceni, Por dentro do cinema, 1993, pp. 43-44.
} 
Sempre lembrado pela crítica especializada glauberiana e por seus inúmeros biógrafos, um fato anotado por Glauber em seu livro Revolução do cinema novo e também registrado por Saraceni em suas memórias parece dar uma dimensão do funcionamento dessas relações preconizadas pelo crítico baiano em terras cariocas, demonstrando como suas ligações aos grupos intelectuais locais fortaleciam-se na medida das contingências de suas ações. Volte-se a atenção ao famigerado "Manifesto bola-bola". Tudo começa com a organização por Glauber, em 1959, de uma seção carioca para a apresentação de seu primeiro filme de curta-metragem Pátio e o filme, também curta, de Saraceni, Caminhos. O local agendado para o evento era a casa de Lygia Pape e lá estaria fração atuante de intelectuais do Rio de Janeiro daquele tempo, entre eles: Mário Pedrosa, Décio Vieira, Ferreira Gullar, Amílcar de Castro, Hélio Oiticica e o próprio Reynaldo Jardim. É de se supor que os filmes e as polêmicas geradas em torno deles impressionaram este último, que de imediato ofereceu o espaço do $S D J B$ para que Glauber e seus jovens amigos de cinema do Rio pudessem escrever um manifesto. Conforme lembra Saraceni, Glauber achou por bem - talvez por pura diplomacia - delegar a tarefa de redação do tal manifesto para Miguel Borges, cuja malsucedida leitura seria feita no Alcazar, como se percebe nas palavras do cineasta carioca descrevendo sua própria reação:

\footnotetext{
"Havia um ar de coisa histórica. Miguel Borges começou:

- Não queremos mais cinema-literatura. Não queremos mais cinema-escultura. Não queremos mais cinema-música. Não queremos mais cinema-dança. Não queremos mais cinema-teatro. Queremos cinema-cinema.

Aí, eu pulei - todos estávamos espantados com um começo de manifesto que pretendia reinaugurar o cinema brasileiro. Aquilo era ridículo.

- Vamos ouvir o fim do Manifesto - gritavam.

- Não quero ouvir mais nada - eu disse. - Isto é manifesto dos anos 20, do cinema mudo. Pretensioso, nem Eisenstein assinaria. Ridículo. Parece o filho pedindo para o pai: Quero uma bola. Não uma bola de futebol, não uma bola de basquetebol, não uma bola de vôlei, não uma bola de pólo aquático, não uma bola de tênis, não uma bola de bilhar, não uma bola de pingue-pongue. Quero uma bola-bola!"3.
}

\footnotetext{
${ }^{3}$ Paulo César Saraceni, Por dentro do cinema, 1993, p. 47
} 
É o caso de partilhar a frase que Glauber redigiu sobre a questão e sobre o momento daqueles jovens, em seu texto agrupado em Revolução do cinema novo: "tudo era

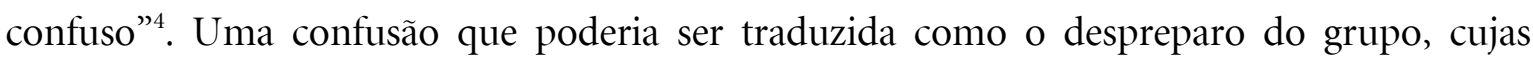
ideias não formavam escopo suficiente maduro para que, como grupo de realizadores e artistas novatos, pudesse exercer um projeto intelectual coeso que refletisse em manifesto afinado político e esteticamente dentro daquelas circunstâncias de momento. É curioso notar que a frustração de Glauber em torno do malogrado manifesto não significou um impacto negativo em seus planos. Significava para ele que as portas do Jornal do Brasil estavam abertas para seus textos; abertas por conta, talvez, de sua estratégia em fazer circular nos meios cariocas, principalmente entre neoconcretos, seu primeiro filme experimental: Pátio.

Por fazer parte da própria história de inserção de Glauber em terras cariocas e, em consequência, a própria explicação à sua ampla colaboração no Jornal do Brasil, voltemos nossos comentários a este seu primeiro curta-metragem, buscando compreender qual seria a razão que o transformou em espécie de cartão de visita de Glauber no Rio de Janeiro.

Aos olhos de hoje, Pátio poderia ser encarado apenas como um grande exercício formal de um jovem cineasta ávido por pegar uma câmera na mão e sair filmando sem um compromisso de enredo e de construção de personagens. Digo, aos ingênuos olhos de hoje. Se observado na ambiência daqueles tempos, este curta-metragem, ao longo de seus pouco mais de 12 minutos, cria um intenso e deliberado diálogo com o que o se disseminava pelo grupo dos neoconcretos cariocas naquele momento. Não se deve esquecer que os embates entre os representantes de uma arte concreta no Brasil, o Grupo Frente, do Rio de Janeiro, e o Grupo Ruptura, de São Paulo, já circulavam em pleno vapor nos meios intelectuais daquele decênio, cujos resultados mais emblemáticos, como se sabe, desembocaram no próprio movimento dos neoconcretos e seu manifesto publicado no SDJB, no início de 1959. E é de supor, sem nenhuma dose de exagero, que Glauber, embora em Salvador, acompanhasse todos estes desdobramentos da arte concreta brasileira de movimentos paulista e carioca.

Pátio é o registro mais evidente que sugere que o jovem cineasta acompanhava muito de perto tudo isso. Espécie de franja do que enunciava o grupo dos neoconcretos talvez por isso tenha havido sua excepcional aceitação entre intelectuais cariocas ligados ao $S D J B$-, neste primeiro curta-metragem não está em jogo uma história ou o conflito de personagens, mas aquilo que se sobressai como a dimensão plástica e geometrizada de um

\footnotetext{
${ }^{4}$ Glauber Rocha, Revolução do Cinema Novo, 2004, p. 50.
} 
espaço cênico por onde circulam sem rumo certo um homem e uma mulher, representados, respectivamente, pelos atores Solon Barreto e Helena Ignez. Circula-se uma história não de personagens, mas de uma forma fílmica que ganha no tempo seu compasso de duração. No caso do jovem Glauber, optar por esse esquema tem estreita relação com buscar uma aderência e um espaço de atuação novo e mais dinâmico fora das fronteiras baianas. Se os domínios em Salvador já estavam, por assim dizer, consagrados e garantidos, cuja boa reputação de crítico local ninguém negava, no Rio de Janeiro a situação era bastante distinta, fazendo dele quase um desconhecido entre intelectuais.

Para uma clareza maior desta ligação entre o que trazia Pátio e o que os neoconcretos anunciavam é preciso confrontar os dois discursos: o do próprio filme e o do "Manifesto neoconcreto", este entoado nas páginas do SDJB ainda naquele início de 1959, buscando verificar seus estreitos pontos de contatos. Inicie-se por este último, cujos signatários são os seguintes nomes: Amílcar de Castro, Ferreira Gullar, Franz Weissmann, Lygia Clark, Lygia Pape, Reynaldo Jardim e Theon Spanúdis. O texto traz em seu fundamento uma resposta ao que se desenvolvia em termos de concretismo na cena paulista, aquilo que os neoconcretos afirmaram ser uma "uma arte concreta levada a uma perigosa exacerbação racionalista" ${ }^{5}$, próprio do que sugeriram ser um desvio mecanicista. Está aí sua primeira diferenciação e será nela que fincarão sua bandeira.

$\mathrm{Na}$ concepção do novo grupo, como estratégia e forma de distinção, havia uma aposta: era preciso propor uma reinterpretação dessa arte construtiva, sem deixar de lado seu vínculo ao geometrismo e sua ligação com o mundo moderno em sua forma de racionalidade técnica. Era também preciso não esquecer que o centro do objeto estético moderno é sua via expressiva distinta da fria maquinaria moderna. Somado a isso, era ainda necessário lembrar de que o simples e puro objeto em si é concebido a partir da própria dinâmica de um organismo vivo, metáfora, esta última expressão, cara ao grupo e presentificada tanto no manifesto como nas produções dos artistas que a ela se vinculavam. Seria, dessa forma, enunciada uma das bases deste pensamento:

\footnotetext{
"Terá interesse cultural específico determinar as aproximações entre os objetos artísticos e os instrumentos científicos, entre a intuição do artista e o pensamento
}

\footnotetext{
${ }^{5}$ Amílcar de Castro et al, "Manifesto neoconcreto", Suplemento Dominical do Jornal do Brasil (SDJB), Rio de Janeiro (RJ), 21-22 mar. 1959, p. 4.
} 
objetivo do físico e do engenheiro. Mas, do ponto de vista estético, a obra começa a interessar precisamente pelo que nela há que transcende essas aproximações exteriores: pelo universo de significações existenciais que ela a um tempo funda e revela.

[...] O neoconcreto, nascido de uma necessidade de exprimir a complexa realidade do homem moderno dentro da linguagem estrutural da nova plástica, nega a validez das atitudes cientificistas e positivistas em arte e repõe o problema da expressão, incorporando as novas dimensões 'verbais' criadas pela arte nãofigurativa construtiva. $\mathrm{O}$ racionalismo rouba à arte toda a autonomia e substitui as qualidades intransferíveis da obra de arte por noções da objetividade científica: assim os conceitos de forma, espaço, tempo, estrutura - que na linguagem das artes estão ligados a uma significação existencial, emotiva, afetiva - são confundidos com a aplicação teórica que deles faz a ciência”.

A esta altura, talvez se possa perguntar (e quem sabe assegurar) se os caminhos de Pátio se cruzam a estes.

Diferente dos outros filmes posteriores de Glauber, mesmo os mais experimentais, este seu primeiro curta-metragem, em linhas gerais, articulou a estratégia entrelaçada pelo pensamento neoconcreto, que tinha nas páginas do SDJB seu quartelgeneral. Pátio visto mais de perto é composto com recursos próprios da base do pensamento neoconcreto. As cenas da natureza vezes se entrecortam na montagem agressiva, ganhando em tonalidade e filiação para a importante representação do momento: a tensão entre o racionalismo concreto e o problema propriamente da expressão. Parece ser representativo dessa posição, em face disso, as comuns cenas de seus personagens em conflito com aquilo que se identifica com a forma mais racional do filme - o tabuleiro formado por pisos.

Como se pode notar a seguir, a dicção neoconcreta é demarcada por uma montagem que rearranja os corpos em movimento tanto dentro das demarcações geométricas de imagem (contraste do piso preto e piso branco no tabuleiro) como da música de clara marcação atonal:

\footnotetext{
${ }^{6}$ Amílcar de Castro et al, "Manifesto neoconcreto", Suplemento Dominical do Jornal do Brasil (SDJB), Rio de Janeiro (RJ), 21-22 mar. 1959, p. 4.
} 


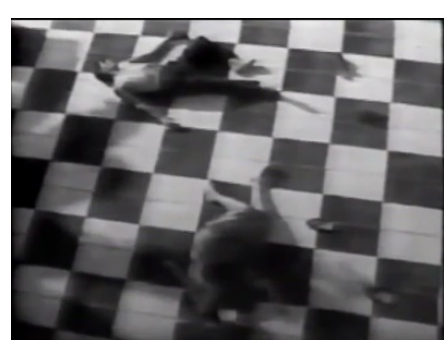

Cena 1

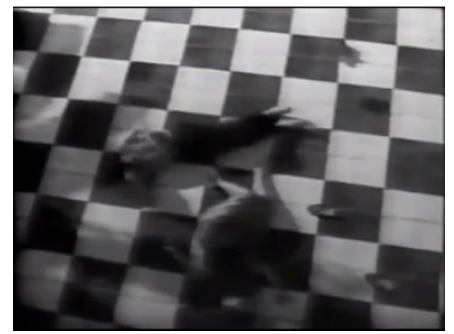

Cena 3

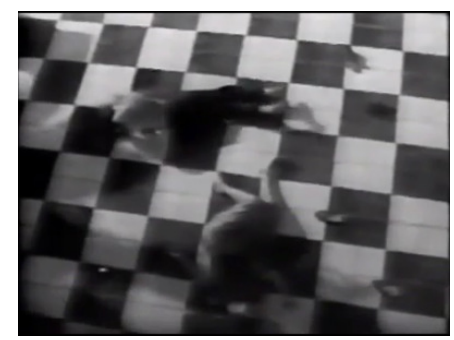

Cena 2

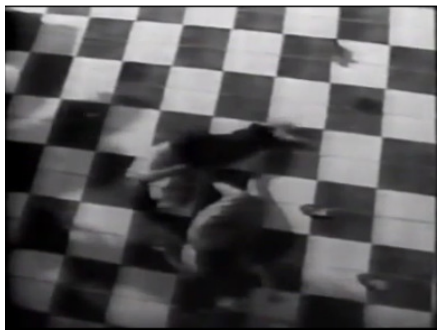

Cena 4

Figura 1. Pátio: cenas dos corpos no tabuleiro.

A imagem fixada no tabuleiro encontra na movimentação de um dos corpos em direção ao outro o modo de ligar o mundo racional dos esquemas retos e matemáticos ao esquema disforme de um movimento sem rumo do personagem. É esta tensão própria dos diferentes enquadramentos e cortes presentes no filme que o posicionam como próprio de um experimento que deseja se fixar como representante de tal pensamento, por assim dizer. Nem o caso de aderência à racionalidade exacerbada, cuja depuração resulta na apenas representação do objeto, nem o caso de aderência ao sentimentalismo figurado e também exacerbado - eis os fundamentos de tal concepção. Em outra sequência, o foco parece estar mais sobre a montagem do que no enquadramento do tabuleiro. Demonstra-se que a nova plástica se aplicava a toda e qualquer instância do filme. É o caso de trazer outro exemplo e notar a seguinte sequência de cortes, formulada em pouco mais de 30 segundos de filme: 


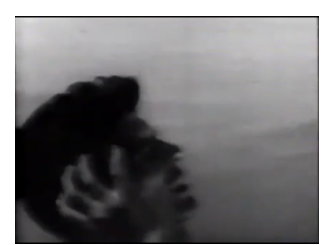

Corte 1

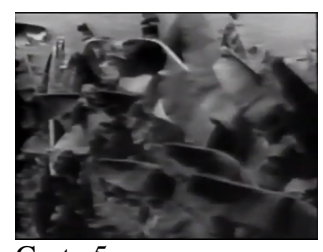

Corte 5

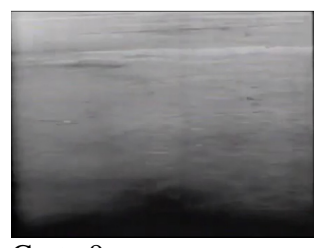

Corte 9

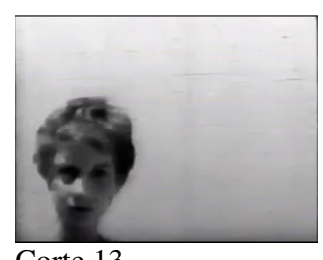

Corte 13

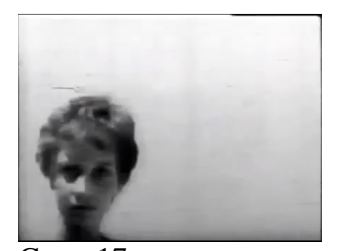

Corte 17

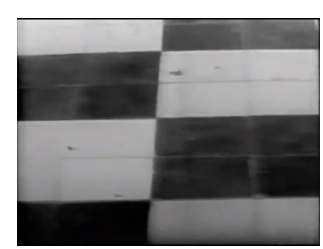

Corte 2

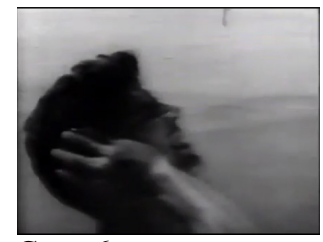

Corte 6

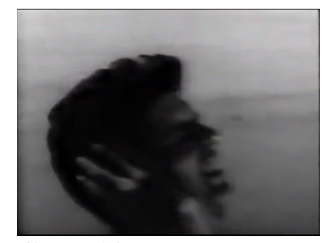

Corte 10

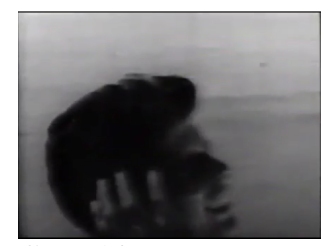

Corte 14

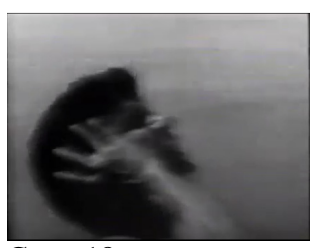

Corte 18

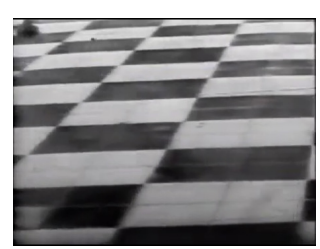

Corte 3

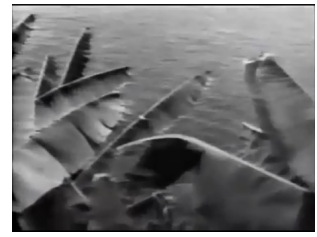

Corte 7

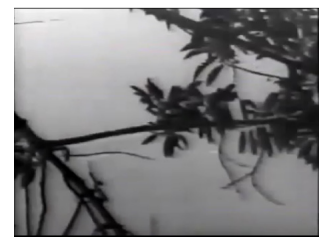

Corte 11

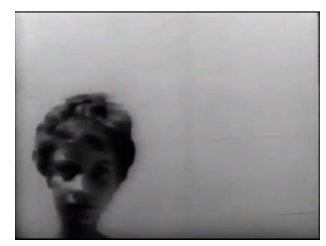

Corte 15

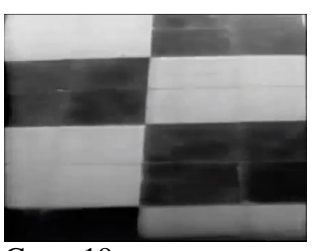

Corte 19

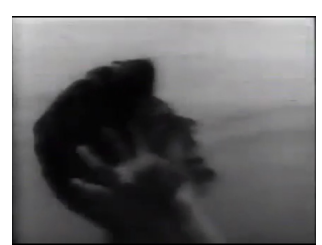

Corte 4

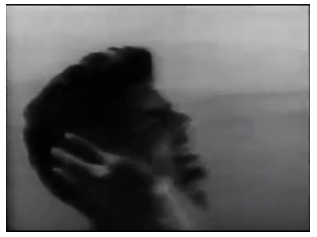

Corte 8

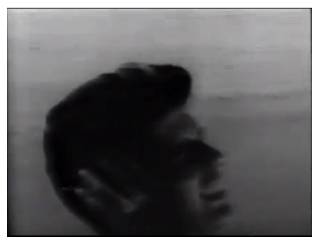

Corte 12

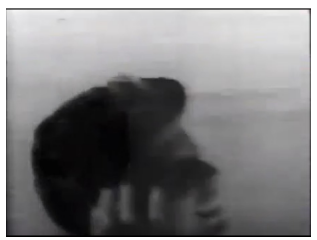

Corte 16

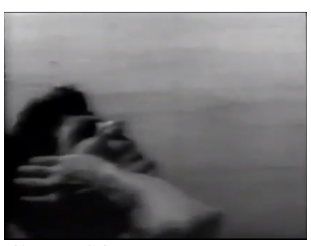

Corte 20

Continua... 


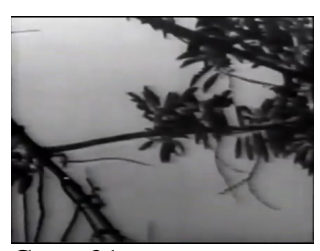

Corte 21

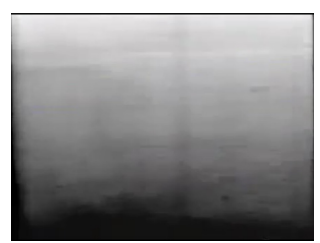

Corte 25

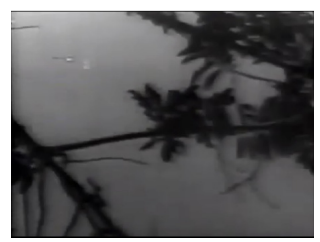

Corte 29

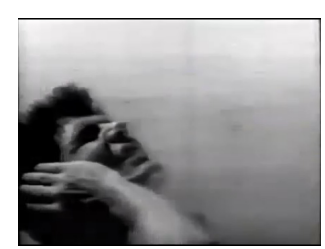

Corte 22

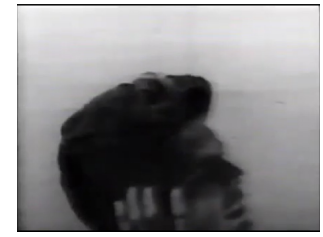

Corte 26

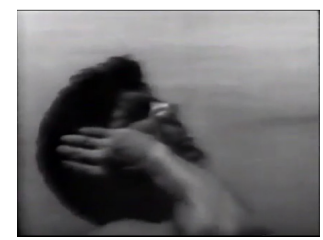

Corte 30

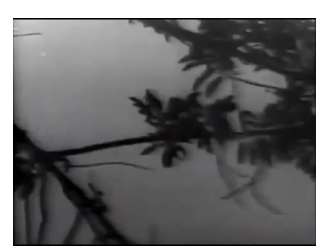

Corte 23

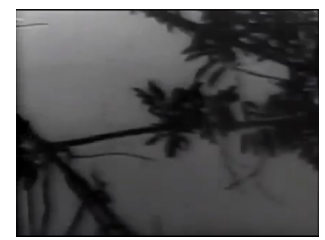

Corte 27

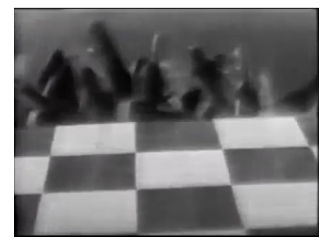

Corte 31

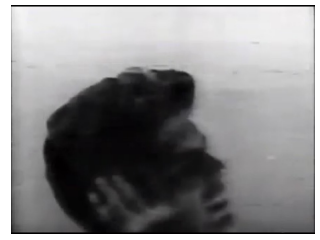

Corte 24

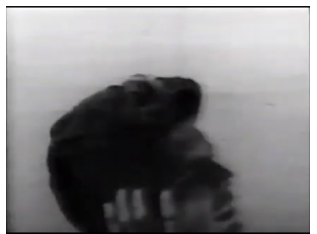

Corte 28

Figura 2. Pátio: cortes da sequência da agonia de um dos corpos.

Como adiantei, toda a sequência, a qual denominei - talvez com certo risco de ser esquemático, dada a natureza do filme - ser a agonia de um dos corpos, aconteceu em pouco mais de 30 segundos de filme montado. Sua montagem de precisos 31 cortes traz como uma das tônicas a cena de um homem a segurar a própria cabeça, num enquadramento que sugere um perfil de agonia e desespero, que se intensifica com a composição musical adotada pelo autor. Intercalada a estas, outras cenas davam a pontuação e relacionavam este mesmo corpo do personagem ao peso de uma natureza (representada nas folhas de uma árvore), à mulher (o outro corpo) e ao tabuleiro de pisos contrastados, marca maior de um mundo racional e geometrizado das formas. Se a agonia poderia ser avaliada como o dado mais subjetivo desta relação imposta pelo mecanismo autor - obra - leitor, dá-se, todavia, lugar a uma relação plástica de forte aderência ao que se preconizava como estética neoconcreta.

O crítico Ronaldo Brito, escrevendo sobre os propósitos do Grupo Frente, cuja continuidade e transformações de ideias seriam a base da vertente neoconcreta, afirmou que a 
conjuntura de então, daqueles anos 1950, ainda estava bastante atrelada a uma arte ligada à representação do mundo empírico: “A questão, como se vê, ainda não era impor uma ideia construtiva da produção de arte. Era, primordialmente, livrar a arte das malhas de mundanismo e a condição de subitem de programas partidários, dentro dos quais desempenhava um papel de simples propaganda ideológica"7. Talvez seja o caso de concordar com o argumento do crítico carioca e pensá-lo numa possível relação para o caso de Pátio. Por certo, o jovem cineasta baiano sabia o que interessava ao grupo e fez em seu primeiro filme tais acomodações. Construir um mundo desfigurado de tal "mundanismo" em que não se estabeleça, com clareza, o projeto histórico e pessoal de cada um dos personagens foi o seu modo mais justo de entrever a questão. Não foi à toa que o filme de Glauber tenha tanto agradado ao grupo de intelectuais neoconcretos na apresentação na casa de Lygia Pape. Casava-se ao que ainda buscavam. Pátio fazia a cabeça do grupo do $S D J B$ e, uma das consequências, foi Glauber ampliar sua rede de relações na capital carioca, não demorando para projetar em tais páginas a letra de um jovem que até pouco tempo atrás ainda era um desconhecido e apenas leitor do periódico fluminense.

Disso tudo, ao se projetar um olhar sobre Glauber e sua tática em Pátio, talvez interesse mesmo duas constatações mais gerais que podem ser assim alinhadas:

1) todo o filme é baseado numa dinâmica formada pela imagem dos corpos dos personagens (sua forma e ligação com o espaço e tempo no mundo moderno). Seu vínculo ainda é com o mundo geometrizado e estruturado por uma plástica, ora do matemático enquadramento do tabuleiro, ora da própria imensidão do mundo natural. Tudo isso significa uma escolha deliberada de seu autor como estratégia em termos de construir sua própria apresentação ao mundo intelectual da metrópole carioca;

2) A estratégia mais válida se tornava na medida em que o jovem se filiava ao grupo que detinha as importantes páginas de um suplemento de boa repercussão em nível nacional.

Abertas as portas do Jornal do Brasil e enfileirada a rede de relações entre os interessados na causa do cinema brasileiro, a estratégia não foi se fixar por completo no mundo estético dos neoconcretos, o que o levaria a se tornar um divulgador programático do movimento. O jovem crítico baiano não queria isto. Por outro lado, foi habilidoso o suficiente para não se desvencilhar de tal mundo bastante cultuado nas fervorosas páginas do

\footnotetext{
${ }^{7}$ Ronaldo Brito, Neoconcretismo, 1999, p. 12.
} 
SDJB. Fez-se logo perceber também por outras razões, principalmente pelas polêmicas que suscitou no jornal carioca e pela forma como assumiu uma discussão em torno do mundo estético do cinema, esta última, sem dúvida, ainda seguindo certas premissas caras ao grupo do SDJB. Suas primeiras contribuições datam de 1958. Embora apareçam no jornal textos seus em diversos períodos, inclusive nos anos 1970, boa parte dos seus artigos foram escritos nos anos de 1959 e 1961, período que aqui se fixará para o exame mais detido.

O tratamento desses artigos foi divido em duas frentes: o jovem intelectual de ação que busca deixar clara suas razões de defesa do cinema nacional e o jovem polemista que procura um grande figurão carioca, para, a partir de um embate com este, desfilar suas ideias. É de supor, mesmo preliminarmente, que em ambos os casos há uma formulação tática. Estes artigos arquitetam sua vontade em continuar a difusão de suas ideias no Rio de Janeiro e, em consequência, pode-se dizer, desencadeiam um significativo aumento do seu prestígio entre os intelectuais de atuação em um centro, como foi o caso da capital carioca. Por certo, não é exagero ainda supor que esse aumento de prestígio possa ter estreitado ainda mais amizades e ter contribuído para as alianças intelectuais mais tarde feitas por Glauber.

\section{O jovem intelectual do cinema dá as caras no Rio de Janeiro}

Em 1959, Reynaldo Jardim, um dos editores do SDJB e um dos signatários do "Manifesto Neoconcreto", escreveu um texto que pode ser considerado o alinhamento de uma posição de grupo (do seu grupo ligado ao Suplemento) para o teatro e sua forma contemporânea de então. Entre as premissas levantadas pelo texto, dizia que o teatro, apesar de cobertura ampla dos principais jornais e críticos, ainda não alcançara um "plano verdadeiro de arte”. Poesia, pintura e escultura, apenas estas manifestações, tinham conquistado o privilégio de um lugar no tal panteão. Ao lado do teatro, excluídos ainda estavam o cinema e a prosa literária.

As afirmações sugerem duas ordens de problemas que o grupo teria que lidar: era preciso deixar à vista nas páginas do $S D J B$ o exemplo mais apurado e procedimento técnico que melhor se ajustasse às manifestações de poesia, pintura e escultura - modelares para o campo artístico e literário brasileiro. Somado a isso, era preciso elaborar outro tipo de 
estratégia para as demais artes, abrindo o $S D J B$ para artigos que pudessem, ao mesmo tempo, combater as manifestações de teatro, cinema e prosa literária em suas formas consideradas mais dependentes e construir um discurso em defesa de novos artistas e intelectuais que estivessem em concordância com tais procedimentos e via política de atuação.

Volte-se para o caso do teatro elaborado por Reynaldo Jardim. Segundo este ponto de vista, o teatro condicionara-se à paternidade literária de sua origem. Nessas circunstâncias, a solução seria pensar um teatro fruto de uma libertação da literatura, que não tivesse o propósito de uma leitura, mas apenas, numa expressão que seria bastante repercutida, o teatro por ele mesmo. Formulava-se, assim, o editor do SDJB: "Deve existir um puro conflito teatral que resulte num teatro mesmo. Qual é essa pura ação teatral é o que cabe descobrir para fazer com que essa arte torne a ter significação. Significação como arte. Este é um tema que merece ser debatido. E este bilhete é para pedir aos interessados numa renovação teatral que sobre ele se manifestem"8.

Tais palavras tornam-se aqui mais importantes, porque demarcam, em certa medida, a escrita política a que o grupo neoconcreto se apoiava e sob ela atuava, encontrando nas páginas do $S D J B$ (sempre nelas!) o lugar mais propício para sua divulgação ampla e irrestrita.

Os textos de Glauber publicados no $S D J B$ demonstram que o crítico baiano, sem ter assumido uma postura explícita de aderência aos neoconcretos, seguia a mesma guia e, portanto, compartilhava naquela situação de colaborador os anseios políticos desse grupo. Seus artigos, principalmente aqueles publicados entre 1959 e 1960, cujo tema com maior recorrência foi, sem dúvida, o cinema brasileiro, seguia a mesma cartilha de ação oferecida por Reynaldo. No caso de Glauber, como divulgador de cinema, as ideias poderiam ser convertidas da seguinte forma: era preciso expor o cinema como arte que pudesse buscar sua ação cinematográfica própria e libertária, com uma ação prática nela mesma, desligando-se de sua também paternidade literária e ganhando, a partir deste ponto, em autonomia e autoridade perante as demais artes e campos artísticos já em maioridade. Para tanto, o pensamento cinematográfico do jovem crítico baiano no $S D J B$, também delineado pelo aspecto combativo ao caráter industrial importado, registra a necessidade de impulsionar o cinema como a arte dos mais jovens.

\footnotetext{
${ }^{8}$ Reynaldo Jardim, "bilhete do editor. teatro mesmo", Suplemento Dominical do Jornal do Brasil (SDJB), Rio de Janeiro (RJ), 24 out. 1959, p. 1.
} 
Em outras palavras, tais artigos de Glauber reiteram e, em alguma medida, comprometem-se com o curso político das ideias daqueles intelectuais. Parece um tanto claro nesta situação, e talvez nem precisasse aqui registrar, que a todas essas ideias o crítico baiano foi acrescentando outras por força das repercussões e dos contatos de suas palavras com a dos outros jovens que, entre outras coisas, viam-se desejosos de construir e assumir o protagonismo no cinema brasileiro independente, este aqui entendido como a recusa de um modelo industrial que fosse mantido pelo financiamento de grandes corporações e por sedentos produtores comerciais.

Cabe um desses exemplos.

Em 24 de outubro de 1959, mesmo dia de publicação do polêmico bilhete de Reynaldo Jardim, Glauber publicou o artigo “Orfeu metafísica de favela” com comentários em torno do filme Orfeu negro, do diretor francês Marcel Camus. O descrédito de Glauber para com Camus não é à toa. Não se trata tão-somente da teimosia de um jovem em formação nos anos 1950-60 em relação a um estrangeiro europeu representante de um cinema de formas mais homogeneizadas e que estivera por estes lados para construir uma narrativa toda ela filmada nas praças cariocas. Convém, em relação a este caso, notar o que está contemplado em sua estratégia de defesa de um novo caminho para o nosso cinema.

Glauber engrossou o coro dos críticos que, em Orfeu negro, notavam apenas a exploração da miséria por uma solução em nome do exotismo. É o negro, a favela no morro, o samba que ofereciam a nova roupagem ao universo mítico de Orfeu. Ora em crítica mais velada, ora em crítica não tão velada assim, Glauber se volta contra a arte sedimentada pelo abuso do lirismo e, para tanto, assume os riscos de tomar como exemplo a relação de Vinicius de Moraes e o filme. Baseado numa adaptação de Orfeu de Conceição, de autoria deste poeta brasileiro, o filme de Camus tem os seus diálogos traduzidos para a equipe brasileira pelo próprio Vinicius, vindo daí um dos ataques mais insinuantes:

"Vinicius de Moraes já é em si um poeta literário. Literário no mau sentido de coisa derramada, romantizante, sensivelzinha com pombos, plumas e passarinhos voando por caminhos de flores. Tudo isso há em 'Orfeu'. Sabemos que não foi Vinicius quem escreveu os diálogos. Mas, traduziu. E se seu espírito fosse contrário ao ambiente de lirismo frouxo, ele cortava e metia tudo num português decente. Mas o fato é que ninguém quis perder a oportunidade, ninguém quis 
fazer o sacrifício que gera, como em 'Il Tetto', de De Sica \& Zavattini, a peça prima"

Se partirmos do pressuposto que Glauber, dada sua relação construída com o grupo do $S D J B$, esteja em estreita linha política amparada pelo grupo de neoconcretos naquele momento, não é forçoso concluir que a crítica ao filme de Camus pela via de um de seus colaboradores, que fora o próprio "poetinha", alcança duas funções com uma só ação. A crítica é não só voltada ao excesso de lirismo de Vinicius como é também o ataque ao conservadorismo que envolvia todas as escolhas de Camus, um filme, aliás, rico em excessos líricos. Duas formas, de se fazer cinema e literatura, que conflitavam com a forma política que o jovem crítico se guiava naquele momento nas páginas do veículo carioca. A crítica glauberiana, como modo de registrar um aspecto negativo da narrativa, salientava o diálogo entre esta forma do fazer literário e a forma do fazer fílmico presente no tecido discursivo de Orfeu negro, discordando do que supunha ser uma amarra literária a que o filme trazia consigo. A metafísica de favela, a que o título já arremete, está enfeixada justamente neste "lirismo frouxo", categoria, esta, determinada na reflexão de Glauber. A gramática cinematográfica de $O r f e u$, assim, pouco ou nada diz de substancial para o cinema no mundo das artes. Apenas reproduz, sem implicações, a marca homegeneizada de uma forma global do narrativo-dramático, de base americana dos grandes estúdios. A favela retida dentro de um mundo enquadrado pelos planos americanos dos personagens revela que o seu autor nada mais é que o retrato da crença de um mundo sem conflitos, envolvido com os mascaramentos dos embates ideológicos. Sua análise parece bastante esclarecedora de seu ponto de vista:

\begin{abstract}
"Que era que Camus pensava que favela carioca fosse? Uma obra de arte vale pelo que vale, pela sua expressão e não pela sua intenção. $\mathrm{O}$ filme vale pela sua feitura, pela sua linguagem fílmica, pelo seu mundo que o fílmico cria ou recria. Seja qual for o mundo: de esquerda ou de direita. Mas olhemos de outro lado: se o artista já vem previamente munido de uma intenção, se ele quer dizer alguma coisa - e principalmente em cinema que é 'culturalmente' um instrumento social -, de ação social - como bem justifica Albert Camus (digo o outro Camus), no prefácio de 'I Want to Live' - ele tem que ser positivo, melhor, progressista, voz de denúncia.
\end{abstract}

\footnotetext{
${ }^{9}$ Glauber Rocha, "Orfeu metafísica de favela", Suplemento Dominical do Jornal do Brasil (SDJB), Rio de Janeiro (RJ), 24 out. 1959, p. 1.
} 
Não há tempo, em lugar nenhum, para lirismo. Se o homem-artista é francês e lá existe o puro Desespero, então fique por lá. A favela é a favela. É uma chaga social, uma chaga mesmo. Não nos interessa falar em defesa da favela porque agora mesmo ela vai ser pintada pelo Turismo para ser mais linda. Lá na favela há um drama. Não é de metafísica: é de fome. Não se tem o direito, diante de uma pessoa que passa fome, de se fazer a mínima literatura com a fome"10.

O que extrair dessa concepção de Glauber?

Há nela, mesmo que em gênese e, portanto, ainda em transformação, uma forma de se pensar o filme nacional. O exemplo que vem de fora e que apenas incentive uma forma de reprodução de prática cinematográfica não é bem quisto por ele. Tanto o exemplo de fora como o filme almejado por nossos cineastas, ambos só teriam alguma validade caso houvesse a exploração da forma fílmica em todas as suas particulares potencialidades, longe da mesmice da montagem cronológica de ligação, do ritmo pouco ou nada conflitivo e do enquadramento que não problematiza aquilo que se está enquadrando. $\mathrm{O}$ enquadramento da favela, assim como do pescador, do homem do sertão, da paisagem árida, só faz algum sentido, dentro dessa linha, caso exista implicações que mobilizassem o espectador e o retirassem de sua zona de conforto. Há, neste caso, uma tendência para um tipo de cinema menos contemplativo. Tratar o cinema por ele mesmo como uma arte possível será uma das suas tônicas dos seus artigos no $S D J B$.

Chamo, neste momento, a atenção para três outros artigos. Agrupei-os pela ligação que eles possuem. Constituem um laço ensaístico comum do que Glauber pensava sobre o cinema entre o ano de 1959 e 1960.

Começo pelo mais antigo deles.

Em 5 de abril de 1959, foi publicado o artigo "Sete pontos: cinema brasileiro". Com ele o crítico baiano trazia à lume uma série de ideias que davam continuidade às suas afirmações em defesa de uma base para a formação de um cinema brasileiro a partir dos seus elementos intrínsecos. Um cinema brasileiro por ele mesmo. Questão preliminar, não por isso menos importante, pensava ele que era preciso chamar a atenção de sua própria geração para que novos jovens pudessem se formar num renovado clima de investigação em torno da

\footnotetext{
${ }^{10}$ Glauber Rocha, "Orfeu metafísica de favela", Suplemento Dominical do Jornal do Brasil (SDJB), Rio de Janeiro (RJ), 24 out. 1959, p. 1.
} 
nova arte, em que vale a "atitude em aplicar a câmara como instrumento de pesquisa do objeto em categoria de absoluto despojamento de artes plásticas ou literatura"11.

Tal como o teatro defendido por Reynaldo Jardim, o cinema dessa nova geração, na fala agora de um de seus porta-vozes do $S D J B$, nasceria de um novo tipo de profissionalização conduzida apenas pelo "princípio de cinema - cinema mesmo". Antes, porém, seria preciso ligar os jovens a esta nova visão, uma "visão filmológica", formulada do entendimento do saber fílmico com base nos conhecimentos "da estrutura e da essência da montagem" e do saber cinematográfico, este mais preocupado com o complexo cultural a que está sujeito. Como modo de construir discursivamente a nova história do cinema brasileiro, Glauber toma para si uma responsabilidade. Quer apresentar, não se distanciando da linha do $S D J B$ e nem tampouco do que já começava a acertar com o grupo de jovens cineastas do Rio, um dossiê, o mais completo possível, dos problemas e das soluções do mundo do cinema, tal como se apresentasse um novo modelo de prática artística para o caso brasileiro. Um novo modelo desejoso de fundar.

Se a nova geração, como afirma, ainda não está preparada para assumir a responsabilidade criadora do nosso cinema, havia sido pelo motivo de não ter tido uma geração antecessora que esta pudesse se espelhar. Isso, por outro lado, não incompatibilizaria a formação deste novo cinema. Dependeria de outros fatores, que são assim colocados por Glauber:

\footnotetext{
"Essa disciplina filmológica é, pois, o que equilibraria novas gerações. Os rapazes em geral estão pretendendo mais do que podem técnica e economicamente. Mesmo como artesãos de montagem. Já se confiam sem o planejamento e a dinâmica físico-intelectual que são constantes indispensáveis no cineasta. Sofrem, por fim, do mal da 'não vivência', vivência que, mais do que o poeta, o cineasta necessita. Sendo cineasta, e não literato ou mistificador desse meio de expressão, ele é forçado a recolher no real seu visual. E para compreender esse real, é necessário vivenciá-lo" ${ }^{\prime 2}$.
}

\footnotetext{
${ }^{11}$ Glauber Rocha, "Sete pontos: cinema brasileiro", Suplemento Dominical do Jornal do Brasil (SDJB), Rio de Janeiro (RJ), 5 abr. 1959, p. 5.

${ }^{12}$ Glauber Rocha, "Sete pontos: cinema brasileiro", Suplemento Dominical do Jornal do Brasil (SDJB), Rio de Janeiro (RJ), 5 abr. 1959, p. 5.
} 
Não havia dentro do cinema brasileiro cineasta que já tivesse, de fato, vivido essa tal "visão filmológica". Dentro desta lógica tecida por Glauber, mesmo os cineastas considerados mais "sérios" - Nelson Pereira dos Santos, Roberto Santos, Rubem Biáfora, Galileu Garcia, Walter Hugo Khoury e irmãos Santos Pereira - ainda não constituíam massa crítica capaz de fazer o deslocamento necessário em direção à mudança paradigmática prevista por ele para privilegiar o cinema como a nova expressão artística moderna por excelência. $\mathrm{Na}$ estratégia de Glauber transborda-se seu desejo (e tática) da própria participação nesta nova construção que se vislumbrava. Dito de outro modo, projetava-se uma necessidade por ele formulada e que seria a base para as futuras inserções sociais desta nova classe a partir de um movimento intelectual, por assim dizer, agregador:

\begin{abstract}
"Dada a nossa pobreza, qualquer idéia para uma organização estética e industrial seria justa e plenamente aceitável. $O$ que não se pode aceitar é desunião fundamental que existe entre cada homem de cinema 'sério' no Brasil. Há carência de 'pensadores'. A crítica é apenas racista de filmes, ainda mais deficiente do que a literária. Os mineiros falam em 'revisão do método crítico', mas até hoje não se sabe bem qual seja tal método e qual influência teria a revisão no pensar cinema no Brasil. As atenções teóricas voltam-se para fora, e ainda assim não teorizam mas apreendem teorias que jamais são aplicadas. [...] A verdade é que a preocupação de fazer cinema se prende a uma necessidade mais individual, embora entrevistas anunciem preocupações coletivas. [...] Movimento, pois, entre nós, seria um pensador que surgisse unindo todos os profissionais em torno de uma idéia, jamais uma academia mas, pelo menos, uma tentativa de salvar a classe mais jovem profissionalizada, essa classe que já é decepção" ${ }^{\text {13. }}$.
\end{abstract}

Estabelecido o contato inicial, deixando o recado para os mais jovens, ainda não profissionalizados, e o alerta para os cineastas “sérios” já com inserção neste novo mercado de bens culturais, embora estes considerados uma "classe de decepção", o passo seguinte do crítico baiano foi desdobrar tais colocações e mostrar quais os novos caminhos que poderiam ser considerados profícuos para o novo projeto de estabelecimento do espaço para a nova arte.

O artigo "Cinema: operação Nordeste", publicado meses depois, em 12 de dezembro de 1959, pode ser considerado uma destas tentativas. Uma de suas apostas foi

\footnotetext{
${ }^{13}$ Glauber Rocha, "Sete pontos: cinema brasileiro", Suplemento Dominical do Jornal do Brasil (SDJB), Rio de Janeiro (RJ), 5 abr. 1959, p. 5.
} 
considerar que a força deste novo cinema surgiria da dimensão da expressão fílmica submetida à temática da realidade nacional, extraindo então sua matéria vertente mais rica. Dali surgiria a nova expressão do cinema nacional. Não parece à toa que seu texto chame a atenção para o deslocamento de duas equipes para o Nordeste para as filmagens dos trabalhos de dois cineastas, estes considerados por ele como inseridos no grupo dos "sérios": Nelson Pereira dos Santos e Trigueirinho Neto. Para Glauber, tratava de um início, o começo de uma ruptura: "dois cineastas da geração atuante do chamado filme sério abandonam a Metrópole sulina (Rio e São Paulo)"14.

Sem desprezar que esta iniciativa de Glauber já trazia em si as contribuições das discussões que ele iniciara com o grupo de jovens cineastas do Rio, repercutindo nas suas palavras um sentimento de ansiedade do próprio grupo na busca de uma força motriz intelectual mais robusta que pudesse distingui-los como intelectuais de inserção na nossa cultura, a visão tratada pelo crítico buscava um marco histórico de formação do nosso cinema. Num ponto de vista que possa se ancorar tanto em uma perspectiva que demarque acontecimentos e conjunturas estabelecidos em momento histórico anterior como em uma perspectiva que registre mudanças estruturais significativas ao ponto de orientar um novo modelo. Trata-se, sem dúvida, da convenção de um novo marco histórico, cujos pontos de referência são aplicados à análise do passado, mesmo que este possa significar esvaziamento de uma tradição, e ao ponto de mudança no presente, a pedra de toque para uma nova história que se formulava.

Glauber é específico em sua formulação. Um novo período se inauguraria com a saída do filme da cidade, sua saída "do drama de apartamento, do melodrama de boate, do neo-realismo de subúrbio"15. Tal equação é formulada sob duas necessidades de defesa: o cinema como arte autônoma e representativa de um mundo desenvolvimentista em fomento e o Brasil como ideia e ressonância de um debate bastante presente desde os tempos do nosso modernismo nos primeiros decênios daquele século: o que somos afinal? Tratava-se da pergunta central e, em consequência, ditaria o tom das novas formulações do nosso cinema na década que se iniciava. A geração de jovens cineastas e ele como um dos principais portavozes no $S D J B$ não demorariam para levantar a bandeira de uma arte construída para o

\footnotetext{
${ }^{14}$ Glauber Rocha, "Cinema: operação Nordeste", Suplemento Dominical do Jornal do Brasil (SDJB), Rio de Janeiro (RJ), 12 dez. 1959, p. 5.

${ }^{15}$ Glauber Rocha, "Cinema: operação Nordeste", Suplemento Dominical do Jornal do Brasil (SDJB), Rio de Janeiro (RJ), 12 dez. 1959, p. 5.
} 
registro em forma de denúncia de uma realidade marcada pelas nossas assimetrias sociais, tornando-se, esta, a base de argumentação que se apresentaria em artigos de jornais, em parte significativa dos filmes em gestação e nos textos-manifestos. Convertidos ao sentimento geral que contaminava uma esquerda brasileira no pré-1964, havia a crença em todos eles de que esta mesma realidade ofereceria a melhor maneira de explorar com originalidade a linguagem para um legítimo cinema brasileiro. As palavras de Glauber beiram a constatação das coisas presentes e sugere um prognóstico, diria otimista, de tais transformações:

"Pelo menos as novas gerações, um pequeno grupo mais jovem do que o atuante, compreendem que o filme brasileiro não pode começar a viver na metrópole e por isso deve penetrar, buscar não só o testemunho social como a matéria para trabalhar uma expressão nascida dela mesma, sem fazer manobras com a linguagem dos outros. Depois há o campo para se começar a armar a indústria: na jungle há matéria exportável, sem concorrência no mercado estrangeiro, material para a exploração a longo prazo. Não se pode exigir para o filme nacional de hoje a consumação e a urgente crise intelectual de todos os cinemas tradicionais" ${ }^{\prime \prime}$.

Completam-se os dois artigos antes expostos em relação ao emblemático período 1959-1960, seu fundamental texto “Bossa Nova' no cinema brasileiro”, cuja publicação é datada de 12 de março de 1960. Supondo ele a impossibilidade de se escrever sobre uma relevante geração ou um movimento com fortes implicações na história do nosso cinema, Glauber registra, todavia, que haveria uma "bossa nova" conduzida por alguns jovens cineastas (os tais cineastas "sérios") que buscavam construir um cinema consciente do processo emancipatório em realização. Era o passo, portanto, para se criar uma forma de identidade do nosso cinema sem precedentes: "as condições de produção são mínimas, os filmes realizados são de baixo orçamento e a pobreza técnica não impede que eles deixem de dizer alguma coisa, mesmo que esta coisa esteja respondendo ainda a realidades particulares, desprovidas de uma ligação que já resistisse ao selo de movimento" ${ }^{\text {17 }}$.

Saliente-se, porém, que o seu texto não objetiva tão-somente o elogio à missão destes novos cineastas da referida "Bossa Nova". Ao menos, isto não é o principal a ser

\footnotetext{
${ }^{16}$ Glauber Rocha, "Cinema: operação Nordeste", Suplemento Dominical do Jornal do Brasil (SDJB), Rio de Janeiro (RJ), 12 dez. 1959, p. 5.

${ }^{17}$ Glauber Rocha, “'Bossa Nova' no cinema brasileiro", Suplemento Dominical do Jornal do Brasil (SDJB), Rio de Janeiro (RJ), 12 mar. 1960, p. 5.
} 
tratado. Sua razão fundamental está baseada no registro da importância do encontro entre estes cineastas "sérios", a tal geração bossa nova, e os cineastas de uma nova geração, na qual ele se inclui e que denominou ser a "bossa novíssima" do nosso cinema. A oportunidade de Glauber é ímpar e ele a encara como a mais apropriada para a apresentação desses novos moços de cinema, que sua visão trata logo de fazê-los surgir "quebrando a eterna monotonia de gerações literárias e plásticas"18, reiterando, mais uma vez, a crença de que estaria se processando o nosso novo cinema, formulado por uma colaboração de várias partes e linhagens, cuja produção independente (portanto, menos industrial) viabilizaria um tipo de arte em que não seria necessário pagar o preço por uma ideia.

Por este e outros aspectos, a defesa do cinema nacional empreitada por Glauber posicionava-se como a reação de sua emergente geração artística contra um suposto servilismo estrangeiro. Duas questões garantiriam neste planejamento de ações seu fator de sucesso: 1) era preciso que a nova geração, além de apresentar seu problema de ordem estética, deixasse clara sua ordem programática de movimento em processamento, sob o impulso político de se organizarem para o enfrentamento dos intelectuais já estabelecidos no circuito cultural; 2) era preciso que a matriz de cinema brasileiro nascesse sem a dependência do cânone dominante de outro cinema moderno; se isso não fosse totalmente possível, seria necessário pelo menos salientar nos textos a recusa aos padrões e influxos externos. Assim, não é de se estranhar que naquele momento Glauber saísse ao ataque a todos os cinemas que pudessem fazer tal frente, embora, faça a ressalva, o futuro diria que muito daquele nosso cinema novo em gestação tenha vindo, entre outras coisas, daquele intercâmbio com franceses e italianos. É comum na argumentação glauberiana frases do tipo: "quem não acreditar em nossas palavras, está desafiado para assistir a A Garganta do Diabo, Bahia de Todos os Santos e Vidas Secas, e depois responder se há ou não há, no Brasil, material muito melhor do que nouvelle-vague" ${ }^{19}$.

No caso de Glauber, o $S D J B$ tornou-se o espaço privilegiado para enredar uma ideia de processamento de uma nova forma para o cinema brasileiro. Em carta endereçada por Glauber a Gustavo Dahl, Paulo César Saraceni e Joaquim Pedro de Andrade, em 13 de junho de 1961, faz-se o registro da inclusão do referido periódico carioca no projeto de

\footnotetext{
${ }^{18}$ Glauber Rocha, “'Bossa Nova' no cinema brasileiro”, Suplemento Dominical do Jornal do Brasil (SDJB), Rio de Janeiro (RJ), 12 mar. 1960, p. 5.

${ }^{19}$ Glauber Rocha, “'Bossa Nova' no cinema brasileiro", Suplemento Dominical do Jornal do Brasil (SDJB), Rio de Janeiro (RJ), 12 mar. 1960, p. 5.
} 
divulgação programática daqueles jovens: "Precisamos trabalhar muito: e no Brasil. Nosso grupo tem de ser um verdadeiro motor. Não podemos parar, fazendo filmes, discutindo e escrevendo. O Jornal do Brasilvai acabar o Suplemento, o que vai me deixar sem armas. Mas consigo outro jornal. É importante que Gustavo escreva para o Estadão. Não pode parar. Mais tarde faremos uma revista. Vou fazer aqui na Bahia a Bienal do Cinema Brasileiro, na Bienal Nacional, que o Museu vai organizar"20.

Se o movimento modernista literário e artístico fora operacionalizado nos anos 1920 e estivera conectado às próprias mudanças urbanas e econômicas, a operacionalização deste novo cinema cumpre, dada as diferenças de época na comparação, uma nova etapa de modernização de um campo artístico brasileiro. O cinema brasileiro moderno desenrolara-se de uma nova onda desenvolvimentista, embora não só a partir disso. Era preciso também entender que a malograda indústria de cinema, em surtos sempre mal resolvidos e mal vistos pela classe intelectual de esquerda, estimulara a iniciativa daqueles jovens pela opção do cinema independente em reação à ideia de imperialismo cultural que aquele tipo de cinema de estúdio trazia consigo e representava.

Para refletir a questão antes exposta, concentremo-nos um pouco mais em 1961. É um ano fundamental para o jovem Glauber. Época de consolidação de sua rede de relações e amizades. Ora com domicílio no Rio, ora com domicílio na Bahia, e com atuações concomitantes na imprensa de ambos os locais, Glauber formulava nos bastidores, junto com outros jovens cineastas de mesma geração - intelectuais que seriam a base do movimento do Cinema Novo -, os passos de um presente e de um futuro em torno dos projetos de filmagens e de intervenções escritas. Somado a isso, consolidara o diálogo com um dos principais intelectuais do cinema cubano, Alfredo Guevara. Com este, Glauber manteve uma constante troca de cartas por um longo período. Guevara dava ao cineasta baiano a dimensão do que acontecia na famosa ilha, nutrindo-lhe ainda mais o imaginário com projetos que ultrapassavam, em longe, o âmbito das nossas fronteiras.

Sem a autocensura e auto-avaliação tácita à estratégia imposta à escrita de um artigo de jornal, em que cada palavra dita a um heterogêneo e imaginado leitor deve ser medida (numa atitude ética sobretudo) e vez por outra suprimida, sua correspondência desnuda outro tipo de relação com a palavra. A troca de cartas entre Glauber e alguns destes

\footnotetext{
${ }^{20}$ Glauber Rocha, Cartas ao mundo, 1997, pp. 158-159. [carta de 13 jun. 1961, Salvador (BA), endereçada por Glauber a Joaquim Pedro de Andrade, Gustavo Dahl e Paulo César Saraceni].
} 
jovens intelectuais brasileiros é referência. Tais cartas dão os contornos do frisson causado por projetos em andamento, recepções motivadas por pequenas intervenções e brigas entre o grupo e opositores.

Veja-se o seguinte exemplo: em maio de 1961, estavam fora do Brasil, participando do Festival de Cinema de Santa Margherita, na Itália, os jovens Joaquim Pedro de Andrade, Gustavo Dahl e Paulo César Saraceni, sendo este último o único premiado brasileiro, com o filme Arraial do Cabo. Cada carta recebida e enviada por Glauber dos e aos amigos é o detalhe de como as coisas funcionavam na dimensão mais íntima dos seus contatos. É o recado do que acontecia com outros latino-americanos: "De uns dois anos pra cá os argentinos fizeram pelo menos dez filmes realmente novos, sobretudo pela mise em scène"21. É a notícia dos enfrentamentos: "Aqui em Santa Margherita vamos brigando com todos os canalhas e no Brasil a briga será maior. Você, Paulo César, Gustavo, Mário e eu, outros que mais tiverem força e entusiasmo, vamos arrasar com os Fernandos de Barros todos"22. É o recado de amigo que configura os laços de amizade e identidade em torno de uma mesma causa: "Aguenta a parada, caro amigo - agora que a coisa começou - eu, Joaquim e Gustavo estamos unidos e estamos contigo, chegou o tempo da gente fazer o filme que queremos fazer - nós contra aqueles filhos das putas"23. É a resposta de Glauber que insere a causa individual de cada um na ordem coletiva de interesses: "[...] do Brasil, Argentina, Cuba e outros latinos nascerão filmes fantásticos. eu já estou articulado com os cubanos, articulados demais. lá eles estão montando uma indústria. se vocês já têm ligações com os argentinos, então poderemos fazer um movimento ambicioso, sul-americano, um movimento de força, independente, capaz de derrubar a porcaria de GEICINES [Grupo Executivo da Indústria Cinematográfica] e estas lesmas cretinas do nosso velho cinema. O grito de independência já foi dado com Arraial. Que filme brasileiro tirou tanto prêmio, filme pobre e sem coberturas oficiais? - Arraial pode representar o início de uma nova época no cinema nacional e vou escrever sobre isto no Jornal do Brasil. O Gustavo devia mandar a

\footnotetext{
${ }^{21}$ Glauber Rocha, Cartas ao mundo, 1997, p. 154. [carta de 26 maio 1961, Itália, endereçada por Joaquim Pedro de Andrade a Glauber].

${ }^{22}$ Glauber Rocha, Cartas ao mundo, 1997, p. 155. [carta de 26 maio 1961, Itália, endereçada por Joaquim Pedro de Andrade a Glauber].

${ }^{23}$ Glauber Rocha, Cartas ao mundo, 1997, p. 156. [carta de 26 maio 1961, Itália, endereçada por Paulo César Saraceni a Glauber].
} 
história de Santa Margherita para O Estado de S. Paulo. É importante que no Brasil se fique sabendo do que houve"24.

Em 1961, às vésperas de finalizar seu primeiro filme de longa-metragem, Barravento, talvez já pela notória repercussão de seus textos na capital carioca, talvez pela forte ligação e segurança que a amizade com os jovens intelectuais desta mesma cidade lhe garantia, Glauber soube avaliar o clima propício para a escrita de um artigo certeiro e já, de certa forma, síntese fundamental da movimentação daqueles novos e barulhentos cineastas, transparecendo, na forma que beira o manifesto, a opção por um cinema de autor. Não por menos ele o incluiria no início de seu livro Revolução do cinema novo como uma das plataformas de sua geração.

Intitulado "O processo cinema", este artigo foi publicado no dia 6 de maio de 1961. Extenso e com características que mesclam a avaliação do artefato fílmico, a experiência de vivência de jovem cineasta e de crítico e as apostas para a criação e manutenção de uma classe cinematográfica única no Brasil, tal texto só poderia aparecer depois de uma longa gestação de ideias praticadas e analisadas em artigos anteriores publicados nos periódicos baianos ou no próprio Jornal do Brasil. Com uma conjuntura adequada, tendo a seu favor um veículo de imprensa de boa repercussão, com demandas do momento que valorizassem o discurso a favor de uma autêntica arte brasileira, sem que isso afetasse o discurso de valorização do trabalho autônomo e independente do artista e de sua arte, o texto de Glauber guarda em si a diversidade de tais condicionantes.

Tal artigo opera, a um só tempo, duas visões: a do crítico e a do cineasta. Cada uma delas deslizando-se uma sobre a outra, sem que se note o prejuízo ou o benefício em nome de uma delas. Espécie de pique-esconde, Glauber brinca com seu leitor. Quando pensamos estar diante do crítico é o cineasta que nos aparece. Quando estamos crentes de ser a vivência do cineasta, o crítico nos avisa que sua visão é que prevalece. As duas experiências, complementares e não excludentes, alternam-se, sem que ao certo possamos identificar com precisão tal chaveamento.

Glauber cobra de todo e qualquer artista do cinema a postura da autonomia em relação às possibilidades estéticas da nova arte. Supondo que as condições das técnicas e da economia sempre medeiam o fazer fílmico, Glauber prevê que a experiência do filme traz ao

\footnotetext{
${ }^{24}$ Glauber Rocha, Cartas ao mundo, 1997, p. 157. [carta de 13 jun. 1961, Salvador (BA), endereçada por Glauber a Joaquim Pedro de Andrade, Gustavo Dahl e Paulo César Saraceni].
} 
artista o dilema entre aderir ao mundo industrial e ser mutilado ou não se deixar levar pelo estrelismo e permitir que suas apostas recaiam ainda sobre o desejo de ajustar suas formas de pensamento às demandas sociais prementes. Ou seja, tornar-se um cineasta pela perspectiva autoral e com responsabilidade criadora. Mas não só com o artista que Glauber é exigente. É também com o crítico desta nova arte. Homem do gosto, o risco do crítico é, segundo ele, deixar-se enganar por aquilo que parece ser, mas não é a justa medida para um bom e honesto cinema. A integridade do cinema, neste caso, sempre passará pelo olhar ético do crítico sério e sincero, cuja capacidade de avaliação, segundo o autor, deveria estar a serviço do projeto de construção do verdadeiro cinema, longe das exigências mercadológicas.

Dividido em três partes, a última de "O processo cinema" parece ser a mais relevante para o que se propõe. É nesta parte do artigo que a mobilidade das perspectivas (a do cineasta e do crítico) manifesta-se com maior frequência. Prevalece uma atitude, não só de exposição dos problemas e constatações da própria experiência, mas também de manifestação de princípios judicativos, convocando aqueles que porventura estivessem desgarrados para uma ação mais politizada em torno da formação do novo cinema brasileiro. Não é coincidência dentro dessa opção que sua análise recaia sobre as condições do cineasta independente brasileiro. Um artista de condições precárias.

Dentre os seus argumentos, destaca-se aquele que busca desmistificar a relação entre condições materiais para o cinema e o sucesso de um filme. Ter boas condições materiais para uma produção não seria a garantia do bom cinema, e vice-versa. Na mesma medida, boas faturas comerciais do cinema não asseguravam bons filmes.

Glauber parte de um princípio, um modelo a ser seguido: seria preciso voltar à condição primeira de artesão, com as miseráveis câmeras e com os poucos metros de filme à disposição, para, só assim, buscar a "escrita misteriosa e fascinante do verdadeiro cinema que permanece esquecido" ${ }^{25}$. No seu fiel da balança, sua opção é uma inversão na relação custo de produção-qualidade estética. Ele reverte, dessa maneira, a situação de se fazer cinema, imperativa de altos investimentos de capital, e a acomoda à situação de prática artística em condição de subdesenvolvimento com baixíssimos recursos para se investir. Ao lado da busca de um tipo de cinema muito mais autônomo, construído sem o amparo de outra modalidade artística, sem que a força de uma palavra interfira para auxiliar a imagem, mas que, enfim, a

\footnotetext{
${ }^{25}$ Glauber Rocha, "O processo cinema", Suplemento Dominical do Jornal do Brasil (SDJB), Rio de Janeiro (RJ), 6 maio 1961, p. 3.
} 
imagem seja por ela mesma o grande vocábulo de escrita do cineasta moderno, convive a preocupação em agrupar uma nova forma fílmica com os problemas e os temários existentes no país. Nessa perspectiva, faz-se todo sentido suas sugestões aos amigos: "É preciso 'nacionalizar' o negócio, tornar o problema 'real' [...] Aqui no Brasil nosso cinema deve ser inicialmente um problema mais ÉTICO DO QUE ESTÉTICO. Compreendo aos poucos que nossa ambição de puristas e formalistas deve ser esquecida" ${ }^{26}$. Trata-se do mesmo caso, como Glauber frisou no $S D J B$, em que o cinema como veículo de ideias pode ser justo, desde que atenda à denúncia de tais assimetrias sociais. Sua experiência em Barravento é então o exemplo desse tipo de acomodação:

\begin{abstract}
"Quando aceitei a profissão de fazer filmes e para isso fiz a penitência de noventa dias numa praia deserta, sem muito dinheiro e com uma equipe humanamente heterogênea, só admiti aquele trabalho contrário às minhas ideias originais sobre o cinema porque tive a consciência exata do país, dos problemas primários de fome e escravidão regionais, e pude decidir entre minha ambição e uma função lateral do cinema: ser veículo de ideias necessárias. Ideias que não fossem minhas frustrações e complexos pessoais, mas que fossem universais, mesmo se consideradas no plano mais simples dos valores: mostrar ao mundo que, sob a forma do exotismo e da beleza decorativa das formas místicas afro-brasileiras, habita uma raça doente, faminta, analfabeta, nostálgica e escrava" ${ }^{\text {27 }}$.
\end{abstract}

Está manifesta em tal postura, como já antes estivera ao descrever os percalços do artigo sobre Barravento escrito para o Diário de Notícias, abordado em capítulo anterior, o mesmo horizonte de interpretações impulsionado por um dos seus grandes mestres da crítica cinematográfica. Refiro-me ao também abordado artigo "Uma situação colonial?", de Paulo Emílio. Quando Glauber compartilha com seu leitor a humilde pergunta "não poderíamos nós, pobres cineastas brasileiros, expurgar os pecados de nossas ambições?”, por trás dela está a cisão compartilhada por tantos outros de sua geração. Uma cisão que, embora defendendo a posição do cineasta como poeta, organizador de um cinema puro artisticamente, encontra

\footnotetext{
${ }^{26}$ Glauber Rocha, Cartas ao mundo, 1997, p. 158. [carta de 13 jun. 1961, Salvador (BA), endereçada por Glauber a Joaquim Pedro de Andrade, Gustavo Dahl e Paulo César Saraceni].

${ }^{27}$ Glauber Rocha, "O processo cinema", Suplemento Dominical do Jornal do Brasil (SDJB), Rio de Janeiro (RJ), 6 maio 1961, p. 3.
} 
no cinema um válido "instrumento de idéias do universo"28. Talvez ainda esteja aí, neste campo de preocupações, a explicação mais adequada para se voltarem, neste primeiro momento, para a construção de um novo cinema a partir de outras paragens que não as cidades: investiram-se da coragem para olhar o asfalto das metrópoles e neles terem avistado o pseudodesenvolvimento, notando que a imagem formada pelo olhar estrangeiro, de índios de gravata e paletó, dizia muito de nossas próprias contradições. Uma das opções reflexivas do movimento gravitaria por aí.

\section{Glauber Rocha, Paulo Francis}

Paulo Francis era um experiente e consagrado crítico de teatro no Rio de Janeiro, em finais dos anos 1950. À época, escrevia no Diário Carioca e vez por outra se metia em assuntos teatrais fora da circunscrição do Rio. A relação com Glauber começa numa destas circunstâncias. Parte-se, na verdade, da publicação de um texto escrito por Francis e publicado em 23 de novembro de 1960, no Diário Carioca, cujo título foi "Teatro da Bahia". Nele, Francis faz duras críticas não só à Escola de Teatro da Bahia como ao seu diretor, Martim Gonçalves. Segundo o crítico do Diário Carioca havia um problema a ser revisto: a escola partilhava de um "diletantismo provinciano".

Sem que seu foco fosse o aspecto teatral em torno do que se encenava e qual seria a qualidade envolvida em cada espetáculo apresentado pela Escola de Teatro da Bahia, a crítica de Francis voltou-se para a estrutura institucional e o que, segundo sua opinião, seriam os equívocos presentes no modo como Martim conduzia os supostos altos investimentos da escola e a forma como suas escolhas teatrais ocorriam. Embora neste primeiro artigo Francis registre o perfil do diretor teatral como persona non grata entre vários nomes do nosso teatro - dizendo que "quase todo mundo que volta de Salvador me fala do terrível regime ditatorial que ele impõe ao aluno"29 -, sua crítica mais severa, e a razão pela qual escreveu o artigo, estaria mesmo no que chamou ser o "desligamento cultural da escola", que, sob seu ponto de vista, fazia com que o diretor fosse à "Europa falar com Vilar sobre o TEATRO, ou com

\footnotetext{
${ }^{28}$ Glauber Rocha, "O processo cinema", Suplemento Dominical do Jornal do Brasil (SDJB), Rio de Janeiro (RJ), 6 maio 1961, p. 3.

${ }^{29}$ Paulo Francis, "Teatro da Bahia", Diário Carioca, Rio de Janeiro (RJ), 23 nov. 1960, p. 6.
} 
Strasberg em Nova Iorque". Nas palavras de Francis, o problema seria bastante grave na medida em que o teatro produzido por Martim em Salvador ao aderir a tudo não estaria aderindo à nada:

\begin{abstract}
"No momento em que o teatro brasileiro faz uma pesquisa de realidades sociais do país, essa escola rica e confortável brinca de Claudel, Tennessee Williams, metendo um Brecht para tornar completo o quadro de divertimentos. Onde está o Brasil em tudo isso, onde está a Bahia, para ser mais específico? Ninguém sabe. A escola pretende ser uma Shangri-la teatral, reduto de pessoas inteligentes e sofisticadas e outras provincianadas. Não há qualquer cultivo do autor brasileiro atuante - a exceção de um Callado que se prestava a um espetáculo exótico - ou procura de autores que pudesse revelar a cultura brasileira em sua especificação baiana" ${ }^{30}$.
\end{abstract}

O crítico do Diário Carioca é irônico, destituindo qualquer seriedade ao teatro produzido em território baiano: havia para ele apenas um "quadro de divertimento" importado por Martim Gonçalves e sem muitas consequências nacionais, cujo esforço maior seria apenas o de se fixar na moda. Estava dado o primeiro recado de Francis. Antes de Glauber tomar partido nesta história, o crítico carioca escreveria mais dois artigos.

No dia 30 de novembro de 1960, Paulo Francis publica o texto "Notícias", empenhando-se em apenas repercutir suas palavras lançadas uma semana antes. Já no artigo publicado, em 4 de janeiro de 1961, sob o título "Millor e outra", as palavras de Francis ganham outro tônus. Seu ataque à Martim é movido por impulsos de descrédito diante do trabalho intelectual conduzido por este, buscando criar um perfil de um artista sem inspirações próprias: “quando começou como cenógrafo, em 'Desejo', de O’Neill, inspirou-se no cenário da produção americana. Mais tarde, fez a cenografia de 'Édipo”, de Sófocles, e a inspiração foi o Old Vic. Daí por diante ninguém mais se deu o trabalho de acompanhar suas inspirações, pois ninguém mais o tomava a sério como artista. O Sr. Eros exilou-se para os Estados, onde o povo ainda não está suficientemente alertado"31.

Até mesmo a produção a partir de Brecht, de sua obra $A$ ópera dos três tostões, que naquele momento era encenada pela Escola de Teatro da Bahia, era colocada em situação duvidosa e desconfiada quanto à sua originalidade: “o Sr. Eros viaja muito, às custas da

\footnotetext{
${ }^{30}$ Paulo Francis, “Teatro da Bahia”, Diário Carioca, Rio de Janeiro (RJ), 23 nov. 1960, p. 6.

${ }^{31}$ Paulo Francis, "Millor e outra”, Diário Carioca, Rio de Janeiro (RJ), 4 jan. 1961, p. 6.
} 
Universidade da Bahia, e deve ter visto a obra de Brecht e Weill em diversos países. O resto não é difícil concluir”32. O tom final do artigo é de cobranças, não para Martim, mas para o reitor Edgar Santos, sob o risco de divulgar outros testemunhos e acontecimentos da Escola da Bahia, o que, ainda segundo o crítico teatral, deixaria todos em situação constrangedora, para não dizer bastante difícil e insustentável. Talvez sem saber, Francis formulara, assim, o estopim para a resposta vinda da Bahia.

É preciso salientar que neste mesmo artigo do dia quatro Francis já havia alertado sobre uma réplica que estava sendo preparada contra ele, a partir de uma encomenda de Martim Gonçalves, um artigo para ser publicado num dos jornais do Rio de Janeiro. Se, de fato, foi uma encomenda ou não, a informação torna-se pouco provável sua confirmação. Interessa, por outro lado, saber que o tal artigo contra Paulo Francis foi escrito por Glauber e publicado no SDJB. Tratava-se, portanto, o começo de outra história, trançada, como se veria no futuro, de uma relação intelectual duradoura. Resta saber como se deu, da parte de Glauber, esta polêmica e quais as conjunturas que a rodeavam.

O jovem Glauber, tendo as páginas do Jornal do Brasilà sua disposição, enche-se de coragem, o que reflete na titulação ousada e raivosa do artigo: "Atenção, Paulo Francis". O tom, tal como acontecera com o trecho final do artigo do dia 4 de Francis, é ameaçador, no sentido que delimita uma cobrança com sanções, um papel de compromisso de seu interlocutor por meio de um artigo público em que ambas as partes partilham publicamente da mesma polêmica, desejando, cada um ao seu modo, a aderência de intelectuais e com elas as repercussões em forma de defesas de ideias.

Glauber inicia seu texto levantando uma hipótese para o repentino interesse de Paulo Francis pelo teatro da Bahia: com a estreia da peça de Brecht e Weill, dado o seu "sucesso fantástico de público", o crítico, por não ter sido convidado e lembrado, sentiu-se, diante da empreitada bem sucedida da Escola de Teatro da Bahia, ultrajado, ele, que, segundo Glauber, "em seu êxtase agressivo, se considera a vedete maior dos críticos teatrais do país" ${ }^{33}$. Mais que isso, Glauber justificou ainda que Francis ligou-se a um grupo dissidente da escola, entre eles Gianni Ratto, Domitila Amaral e Ana Edler.

\footnotetext{
${ }^{32}$ Paulo Francis, "Millor e outra", Diário Carioca, Rio de Janeiro (RJ), 4 jan. 1961, p. 6.

${ }^{33}$ Glauber Rocha, "Atenção, Paulo Francis", Suplemento Dominical do Jornal do Brasil (SDJB), Rio de Janeiro (RJ), 14-15 jan. 1961, p. 7.
} 
Como maneira de deixar a polêmica mais esquentada do que já era, como forma de combater o argumento de Francis, segundo o qual todos estes teriam saído por conta do ditatorialismo de Martim Gonçalves, a opção de Glauber foi levantar as razões - é claro, sob sua perspectiva - pela qual Ratto havia saído:

"Pois bem: o Sr. Ratto, vindo para a Bahia em companhia da esposa, obteve de Martim Gonçalves condições especiais de diretor, com salário digno e liberdade de escolha e montagem das peças. Que desejou Ratto em seguida? Ser diretor da Escola. Usando de uma demagogia verbal bem peculiar aos italianos importados, organizou um pequeno grupo de alunos em fase de delírios sexo-sociais e começou a sabotar as atividades do diretor. Unido a Domitila do Amaral promoveu festinhas originais nos jardins e recintos fechados do Teatro Santo Antonio, toda vez que Martim Gonçalves se afastava para o Rio. A exótica Domitila do Amaral promoveu uma procissão dionisíaca e alguns alunos chegaram a despir-se. As aulas eram uma mistura de espiritismo com subliteratura. Tudo isto visava desmoralizar Martim Gonçalves. E muitas destas coisas se processaram às escondidas, mesmo quando o diretor estava presente. Nesta época a Escola conheceu um dos seus poucos fracassos que foi As três irmãs, montada por Ratto. Mesmo assim, sabedor do que passava, Martim concedeu uma segunda oportunidade ao professor contratado: a montagem de Chica da Silva, de Callado. Terminado o ano letivo, o diretor da Escola, embora só conhecesse metade dos fatos, resolveu não renovar o contrato de Ratto, Domitila e Luciana Petrucelli" ${ }^{34}$.

A ação de levantar as nuances da saída de Ratto e o grupo que ao redor dele gravitava, desde alunos e escudeiros, deve ser encarada como uma estratégia inerente à própria polêmica alimentada pelo jovem. Deve-se lembrar que Glauber, ainda sem o espaço de atuação intelectual definido nas paragens cariocas, só restava a ele, na pesada missão de atacar um crítico bem estabelecido e com boa reputação, partir para a contra-argumentação da principal fonte de informação de Paulo Francis. Sobrava a palavra de um contra o outro. Isto é, a reputação do dito pelo não-dito. Precisando engrossar o caldo da argumentação em defesa da cultura baiana, o passo seguinte seria demonstrar a Francis que os caminhos seguintes da instituição estavam fortalecidos. Mesmo com a saída de Ratto e os companheiros ligados a ele, a Escola continuou a montar espetáculos, que, segundo Glauber, tornaram-se os

\footnotetext{
${ }^{34}$ Glauber Rocha, "Atenção, Paulo Francis", Suplemento Dominical do Jornal do Brasil (SDJB), Rio de Janeiro (RJ), 14-15 jan. 1961, p. 7.
} 
maiores sucessos desde o seu surgimento. Embora seu texto justifique essa tentativa de demonstração dos benefícios que a Escola pôde ter trazido ao mundo provinciano de então da cultura da Bahia, seu tom provocativo, ora beirando a forma lacônica dirigida ao crítico carioca, é que se sobressai. A gama de abordagens é ampla. Sobre as tais verbas suntuosas escreve: "Se fosse processado para provar, provaria?"35; sobre falar sem conferir a situação local por ele mesmo escreve: "Mas falar mal da grande montagem da Ópera, sem ver; falar mal da Escola sem nunca ter vindo aqui; tripudiar sobre o caráter de Martim Gonçalves sem conhecê-lo de perto; e devassar a vida econômica da Escola, sem documentos que provem suas denúncias, é desonesto e perigoso" ${ }^{36}$. Nada, porém, se compara ao recado final do texto:

\footnotetext{
"Se Paulo Francis for tão viril e honesto como propala, não deve ir para suas tocais responder este artigo e atacar mais a Escola. Deve vir à Bahia. Aqui ninguém vai agredi-lo, como já fizeram algumas vezes. Eu pago a passagem e vou recebê-lo. Todavia, se o mesmo crítico continuar com tamanho despropósito, falando por olhos de terceiros, eu estarei no Rio ainda em janeiro!" ${ }^{37}$.
}

As provocações de Glauber são aceitas por Paulo Francis. A resposta é imediata e se inicia no dia seguinte ao texto publicado do SDJB. Em tom de deboche, limita-se a encarar o texto de Glauber como se fosse do próprio Martim Gonçalves e como forma de provocação que escamoteia uma pretensão que não passaria, na concepção do crítico carioca, de um "pedantismo provinciano pseudocosmopolita" da referida instituição.

A réplica de Francis não se resumiu a um texto. Por mais de uma semana, o crítico carioca revolveu o assunto em diferentes frentes, com textos próprios, com entrevistas e a abertura de espaços para opiniões que reafirmassem seus argumentos contra a instituição baiana e seu diretor. O primeiro deles é o seu texto de opinião "Ainda a baianada”, publicado no Diário Carioca de 15 de janeiro de 1961. Nele, o crítico diz estar desapontado com a resposta vinda da Bahia, esperava "um pouco mais de originalidade" ${ }^{38}$. O tom, já de um

\footnotetext{
${ }^{35}$ Glauber Rocha, "Atenção, Paulo Francis", Suplemento Dominical do Jornal do Brasil (SDJB), Rio de Janeiro (RJ), 14-15 jan. 1961, p. 7.

${ }^{36}$ Glauber Rocha, "Atenção, Paulo Francis", Suplemento Dominical do Jornal do Brasil (SDJB), Rio de Janeiro (RJ), 14-15 jan. 1961, p. 7.

${ }^{37}$ Glauber Rocha, "Atenção, Paulo Francis", Suplemento Dominical do Jornal do Brasil (SDJB), Rio de Janeiro (RJ), 14-15 jan. 1961, p. 7.

${ }^{38}$ Paulo Francis, "Ainda a baianada", Diário Carioca, Rio de Janeiro (RJ), 15 jan. 1961, p. 6.
} 
desprezo irônico, que segue ao longo de todo o texto, potencializa-se nas respostas às provocações mais sisudas de Glauber:

\begin{abstract}
"Não vou, por certo, entrar em considerações sobre o meu humor. Quanto à minha virilidade, devo dizer que às vezes me ocorre a suspeita lisonjeira de que sou realmente 'sexy', tal a preocupação que meus detratores têm com o assunto. Infelizmente, não posso provar minha virilidade na Escola da Bahia. Me parece o lugar menos apropriado possível para semelhante prova. Quanto à agressão e ao processo, sou a pessoa mais fácil de ser encontrada neste mundo"39.
\end{abstract}

Está equacionado no texto de Paulo Francis, por esta forma de desprezo do que acontecia em terras baianas, a prática de confrontar duas vidas intelectuais e dois campos teatrais. Para o crítico carioca, a vida na metrópole é o mais vivo fermento para um campo teatral pujante e sério. Em contrapartida, a vida provinciana, limitada, por assim dizer, por um "complexo socioeconômico" defasado, produz um teatro igualmente de província e, em certa medida, estéril ao que se refere ao agrupamento mais ou menos coeso de ideias nacionalistas para o nosso teatro. Nesse horizonte, não causa estranhamentos suas palavras: "A escola até hoje nunca fez nada que pudesse de alguma maneira influenciar o panorama cultural brasileiro" ${ }^{\prime 4}$.

É neste sentido também que todo o perfil de Martim Gonçalves traçado por Francis, neste e nos demais textos, tem o objetivo de trilhar um homem de teatro confuso, sem a medida exata do que pensa e pratica, que sequer reflete sobre a hipótese de reafirmar um teatro na Bahia com pretensões mais encorpadas. Tratava-se, em outras palavras, de um perfil sem a aura de autoridade cultural. Residiria aí sua decisão de retratá-lo como um homem que pouco diferencia as ideias correntes de um Brecht, de um Planchon ou de um Stanislavski. Construída pelo crítico carioca, essa disforme e incoerente figura diletante teria, portanto, seu reflexo imediato na própria instituição que dirigia, ou seja, um centro de ensino sem uma bem sucedida programação cultural: “O que se espera de um centro de ensino é um currículo eficiente que abranja os diversos aspectos da experiência teatral e que decorra de uma visão cultural peculiar às condições sociais do país em que funciona. A Escola da Bahia,

\footnotetext{
${ }^{39}$ Paulo Francis, “Ainda a baianada”, Diário Carioca, Rio de Janeiro (RJ), 15 jan. 1961, p. 6.

${ }^{40}$ Paulo Francis, "Ainda a baianada”, Diário Carioca, Rio de Janeiro (RJ), 15 jan. 1961, p. 6.
} 
na melhor das hipóteses, faz um ou outro espetáculo de boa qualidade enxertado de profissionais de todo o mundo" ${ }^{31}$.

Embora a polêmica de Paulo Francis sempre projete a maior parte de seus argumentos buscando atacar a instituição de teatro baiana e seu diretor, na continuidade das publicações dos seus textos, Glauber foi um dos atingidos. Em 19 de janeiro daquele ano, Francis publica a entrevista intitulada "Ana Edler e a situação da Escola da Bahia”, cujo relato da atriz dirige-se em dura crítica ao jovem: "o nome que assina o artigo no 'Jornal do Brasil', disse-nos ela, 'não tem autoridade para falar nem pró nem contra a Escola da Bahia. Quando fui contratada por Martim Gonçalves como professora, este moço escrevia artigos violentos contra Martim em jornais estudantis" ${ }^{42}$.

No dia seguinte, como se poderia prever, novo depoimento é publicado no espaço da coluna de Paulo Francis. Tratava-se de uma carta enviada por Gianni Ratto, em resposta ao que dele foi falado por Glauber. De modo análogo ao que Ana Edler havia feito em sua declaração, Ratto segue a mesma linha ao delinear a figura do jovem crítico: "um indivíduo que mal conheço e que no tempo - já tão longínquo - no qual ensinei na Escola da Teatro da Bahia, limitava suas atividades intelectuais a saídas na rua em manifestações estudantis cujos cartazes - às vezes até engraçados - eram mais do que alusivos dos hipotéticos transvios sexuais dos professores da dita Escola" ${ }^{\text {"43 }}$. E mais uma vez, levanta-se a hipótese de que Glauber seria mais um fantoche nas mãos de Martim: "Hoje, este senhor, com o mesmo espírito carnavalesco (embora melhor seria dizer carnachalesco), empresta seu nome a alguém que não tem a coragem de tomar a responsabilidade do que deseja afirmar" ${ }^{\text {" }}$. Por conta de uma viagem, como relatou, "tentando realizar um documentário" nos "longes sertões de Cocorobó \& Canudos", Glauber escreveu sua resposta semanas depois do último texto publicado por Francis. Publicado em 11 de fevereiro daquele ano, mais uma vez no $S D J B$ - habitué do crítico em terras cariocas naquela época -, "Tope a parada, 'Mr.' Francis" é um longo artigo em que ele se debruça sobre o que acredita ser o problema central em toda aquela polêmica: qual foi e qual ainda seria a missão da Escola de Teatro da Bahia.

\footnotetext{
${ }^{41}$ Paulo Francis, “Ainda a baianada”, Diário Carioca, Rio de Janeiro (RJ), 15 jan. 1961, p. 6.

${ }^{42}$ Paulo Francis, "Ana Edler e a situação da Escola da Bahia”, Diário Carioca, Rio de Janeiro (RJ), 19 jan. 1961, p. 6.

${ }^{43}$ Gianni Ratto em Paulo Francis, "Ratto acaba com intrigas da Escola da Bahia”, Diário Carioca, Rio de Janeiro (RJ), 20 jan. 1961, p. 6.

${ }^{44}$ Gianni Ratto em Paulo Francis, "Ratto acaba com intrigas da Escola da Bahia”, Diário Carioca, Rio de Janeiro (RJ), 20 jan. 1961, p. 6.
} 
Por esta via é que o jovem crítico formularia sua estratégia de discurso e escreveria a última das respostas de uma polêmica iniciada meses atrás.

O teor desse novo texto de Glauber é distinto daquele de seu primeiro texto publicado no $S D J B$. Seu tom ameaçador dá vazão a um tom, digamos, mais conciliador, em que se tem lugar a análise mais detida do percurso e das transformações ocorridas na cidade com a vinda da Escola de Teatro. Se seu propósito outrora era o de atacar raivosamente o outro polemista, neste novo momento ele quer mostrar como sua opinião sobre a Escola foise modificando e cristalizando-se como próprio sintoma do que acontecia em Salvador. O reconhecimento de que, em certo momento, lá nos primórdios da Escola, ele, muito mais jovem, havia sido uma atuante oposição dos rumos da Escola, fato, inclusive, salientado pelos seus críticos, e que naqueles dias atuais, sob novas circunstâncias e com as transformações ocorridas, havia sem sombra de dúvida um novo diálogo imposto entre a sociedade e a difusão praticada pela instituição e sua direção, era, no fundo, uma forma de demonstração da eficácia da Escola no mundo cultural baiano. Emprega-se, grosso modo, o recurso do exemplo a ser seguido. Tal como aconteceu com ele, cuja opinião sobre a Escola modificou-se com o maior convívio e ambientação, é certo, dentro desta lógica, que o mesmo ocorreria com qualquer um que lá estivesse. Francis é o alvo. Daí, em mais de uma vez, sua atitude de reiterar o convite ao crítico carioca. A crença de que a provocação poderia transformar-se em concordância a partir de um novo entendimento do que se passou nos limites de Salvador.

Há, é claro, um jogo retórico dentro de tudo isso. Um jogo retórico de defesa de um ponto de vista discordante ao do outro polemista e que é a base afirmativa de uma ideia trazida por Glauber. O jovem baiano busca desnudar Francis pela demonstração da viabilidade de um projeto de ensino e difusão ancorado no Norte do país, em que o Sul do país já não pode ser o exemplo de atitude e ação. Coisa, sem dúvida, que o crítico carioca não acreditava. Essa falta de crença do crítico carioca, em certo sentido, levantou a matéria para a contra-argumentação provocativa do cineasta baiano: "Desejamos, então, apenas um teatro burguês para Rio e São Paulo? É este o teatro brasileiro pelo qual os senhores se batem tão arduamente? [...] Como pode, então, uma pessoa acusar outra de diletante e alienada, se ela mesma acha que o centro do mundo é o Rio e São Paulo?" ${ }^{45}$. É preciso notar que, para Glauber, desconhecer os feitos da Escola de Teatro teria o mesmo efeito que desconhecer os

\footnotetext{
${ }^{45}$ Glauber Rocha, “Tope a parada, 'Mr.' Francis”, Suplemento Dominical do Jornal do Brasil (SDJB), Rio de Janeiro (RJ), 11 fev. 1961, p. 4.
} 
movimentos culturais que percorreriam todo o país. Dito de outro modo, o reconhecimento da Escola como um feito cultural significativo é também o seu próprio reconhecimento como artista, é o reconhecimento da própria geração de artistas baianos, da qual ele se inseria. Com a polêmica, seu raio de exposição de ideias alargava-se de maneira considerável. A defesa feita antes em atitude local, principalmente com o grupo mais conservador de Salvador, que não via com bons olhos as movimentações dos grupos culturais ligados à universidade, fechava um ciclo de suas intervenções; com a nova polêmica um novo ciclo se sedimenta e ele pôde ampliar sem grandes dificuldades o campo de ação para o nível nacional: a defesa da cultura do Norte no Sul do país.

As publicações no Diário Carioca, por parte de Francis, e as publicações no $S D J B$, da parte de Glauber, mais que uma polêmica entre um recém-chegado e um estabelecido no centro cultural do Rio de Janeiro ou a defesa e o ataque de uma figura nada unânime como Martim Gonçalves, talvez possam ser pensados a partir da controvérsia entre dois grupos e duas frentes de atuação no campo intelectual de então. Visto sob as lentes de uma aventura importada, o que estava ocorrendo na Bahia é recepcionado por Francis a partir de sua interpretação, no mínimo, centralizada no mundo cultural do Rio e São Paulo. O que abre brecha para, de certa forma, pensar que a crítica de Glauber nesses aspectos não era tão improcedente assim. Francis e seu grupo de dissidentes, no fundo, cometiam um equívoco: confundiram as movimentações culturais na Bahia com o que era a figura de Martim Gonçalves. Ao se acompanhar os cruzamentos do que era escrito sobre Martim na imprensa $\operatorname{local}^{46}$, ora construindo uma figura grotesca, ora uma figura de encanto, só demonstram o arriscado terreno movediço que o crítico carioca atolava-se, talvez sem saber em que grau.

Qualquer improvisação, como foi o caso de Francis, que procurasse construir uma figura com características que em nada contribuía para o campo teatral e artístico local, ganhava ares de desavença pessoal e inverossimilhança, dada a movimentação incontestável trazida pela Escola de Teatro nos circuito artístico baiano. Somado a esta forma de análise, cujo modelo de ação era dado pelo que acontecia mais ao Sul, suas críticas, quer queira, quer não, solidarizavam-se ao provincianismo local, de parcela de imprensa, via jornal $A$ Tarde, que reproduziam seus textos do Diário Carioca, com o intuito de endossar, em termos bastante locais, o ataque e a desestabilização política da própria Escola de Teatro. Tratava-se,

\footnotetext{
${ }^{46}$ Cf. Jussilene Santana, Impressões modernas, 2006, pp. 179-196.
} 
enfim, de uma questão que se particularizava, expondo o que poderia ser um paradoxo do modelo pregado pelo crítico carioca e aquilo que seus textos, ao final das contas, serviam.

Colocando os devidos pesos na balança, Glauber, neste sentido, vai atuar de modo mais estratégico. Ou seja, apenas comprometido com o que ele de fato sabia julgar, ou seja, o grau de repercussão que aquilo poderia gerar. É curioso notar que o crítico baiano, atuando num espaço bastante cosmopolita, como foi o caso do $S D J B$, soube dimensionar os pontos limites desse gênero de polêmica em sua defesa: até onde poderiam ir suas palavras a favor de Martim Gonçalves. Até onde poderia chegar suas defesas para uma arte local e para a ampliação do circuito artístico pela via da Escola de Teatro, sem que seu discurso transformasse-se em apelo provincial e local; até onde poderia interpelar seu interlocutor, sem que isso pesasse contra?

Toda vez que Glauber trouxe, na forma de vocativo ou na segunda pessoa do singular, Francis ao seu texto foi como modo de deixá-lo a par de fatos locais, reiterando o que seriam os erros do crítico carioca. O fraseado passa por "Você entendeu meu artigo e não é tão bobo para não saber que fez um veneno feio [...] Sinceramente, Francis, eu estou fazendo perguntas estabelecendo o debate que, você disse, Martim recusou [...] Mas a sua responsabilidade de crítico também está em jogo, porque acredito que mesmo outros inimigos de Martim Gonçalves e todos os escritores brasileiros que conhecem a Escola, como também o teatro sério do Brasil, não poderão admitir a sua infantil negação de uma evidência. Tope a parada, por favor!" ${ }^{37}$.

A opção, como se poderá notar, foi pela forma de um texto mais límpido. Martim é exemplo pelo seu empenho, que logo se projetou nos feitos da instituição: "sempre deu dias e noites totais ao trabalho e nunca fez a menor concessão de favoritismo, motivo geral de uma série de discordâncias. O vedetismo nunca viveu na Escola, a (sic) nunca o diretor permitiu as menores atividades amadorísticas. É claro que a Escola teve falhas" ${ }^{38}$. As discordâncias existem na medida em que é para o bem-comum da arte baiana, quase como seu trunfo argumentativo em nome de uma transparência, forma persuasiva de angariar os supostos leitores indecisos na polêmica: "O teatro do Novos, da Bahia, grupo originário da cisão com a Escola. Eu mesmo fui quem lançou as primeiras publicidades deste grupo na

\footnotetext{
${ }^{47}$ Glauber Rocha, "Tope a parada, 'Mr.' Francis", Suplemento Dominical do Jornal do Brasil (SDJB), Rio de Janeiro (RJ), 11 fev. 1961, p. 4.

${ }^{48}$ Glauber Rocha, “Tope a parada, 'Mr.' Francis”, Suplemento Dominical do Jornal do Brasil (SDJB), Rio de Janeiro (RJ), 11 fev. 1961, p. 4.
} 
imprensa e quem abriu, junto aos outros jornais, um crédito de confiança que não seria conseguido sem a minha interferência. Deixei os motivos pessoais de minha amizade com Martim Gonçalves e prestei como todos da Bahia, os mesmos aplausos”49. Enfim, o que vale é a divulgação da movimentação baiana, seu dado de originalidade, conforme coloca: "Aqui, pela primeira vez no Brasil, se realiza um teatro verdadeiramente antiburguês. Quem viu, não nega! O interesse pelo teatro brasileiro sempre foi o princípio básico. A pesquisa e a integração cultural deste trabalho estiveram presentes na última Bienal, quando a Exposição Bahia, da Escola, foi um sucesso, principalmente junto aos melhores críticos europeus que lá estiveram" $" 50$.

É dessa ampliação da própria polêmica entre um grupo e outro que Glauber talvez tenha notado que a repercussão de suas palavras já começava a entrar nos vivos ouvidos do Rio de Janeiro de então. Confiança, com certeza, para que sua atuação tornasse mais realística como o novo nome nordestino que ali chegava entre tantos outros já presentes naquele centro. Mais tarde, em 1963, confessaria em uma carta a sua mãe, a necessidade da mudança: "não é mais possível ficar aí na Bahia, é muito pequeno pra mim e eu aqui estou tendo oportunidades que podem me ser muito úteis no futuro. a senhora pode bem compreender que se eu ficasse na Bahia seria a morte para mim" ${ }^{51}$. Naquela altura, o Rio deixara de ser, para ele, uma novidade e transformara-se em uma realidade para uma nova vida intelectual. E das mais vivas dentro de sua trajetória.

\section{Prática de consagração pelo livro Revisão crítica do cinema brasileiro}

Já com uma produção escrita bem divulgada no Jornal do Brasil e com interlocução e laços de amizades mais bem definidos, é possível detectar entre 1962 e 1963 que Glauber exercia uma nítida liderança no interior do grupo dos jovens intelectuais do Cinema Novo. Basta acompanhar o diálogo epistolar entre ele e esses jovens intelectuais para

\footnotetext{
${ }^{49}$ Glauber Rocha, “Tope a parada, 'Mr.' Francis”, Suplemento Dominical do Jornal do Brasil (SDJB), Rio de Janeiro (RJ), 11 fev. 1961, p. 4.

${ }^{50}$ Glauber Rocha, “Tope a parada, 'Mr.' Francis”, Suplemento Dominical do Jornal do Brasil (SDJB), Rio de Janeiro (RJ), 11 fev. 1961, p. 4.

${ }^{51}$ Glauber Rocha, Cartas ao mundo, 1997, p. 183. [carta de 1962, sem data precisa, Rio de Janeiro (RJ), endereçada por Glauber a Lúcia Rocha].
} 
notar a precisão com que ele dimensiona os afazeres do que escrever, filmar e falar em público. Glauber, sem sombra de dúvida, é o mais incisivo e insistente deles. É ele quem recolhe os exemplos, lembrando a agenda programática aos companheiros. É ele quem estabelece linhas de atuação dentro e fora do país, atraindo novas amizades que pudessem porventura ajudar a empreitada. É ele quem recomenda e às vezes exige um maior engajamento de ideias políticas, solicitando de todos os participantes um novo texto de divulgação, a entrada em um projeto de filme ou o dimensionamento de roteiros e ideias com o objetivo de melhor se adequar ao mundo e clima de cinema novo que se construía.

Tais cartas que Glauber escreve projetam um gênero que mistura o aspecto militante e a construção da agenda de atuação do grupo, buscando, a um só tempo e em cada frase de impacto destinada ao interlocutor, um modo de acomodar uma coesão de ideias pertinentes aos objetivos coletivos traçados, em grande parte, por ele próprio para o novo cinema brasileiro. É bastante comum, neste roteiro de atuação esboçado por Glauber, que ele, em mais de um momento, force a nota e delineie, seja no mundo do cinema, seja na sociedade, um perfil trágico do que acontecia. Um perfil que, sem demora, poderia servir ao próprio movimento, em sua visada pelo reconhecimento no campo artístico de então. Num destes casos, ele escreve a Paulo César Saraceni sobre o impacto de concatenar a realidade social e o projeto de construção de filmes: "Paulo, a revolução no norte é um FATO. crescemos dia a dia. o mais importante dos filmes brasileiros será este filme camponês. 200 mil pessoas morrem de fome e sede nas estradas, enlouquecem, assassinam. [...] se você olhar o norte 24 horas, você enlouquece de raiva e vibra de entusiasmo" ${ }^{2}$.

A notar que Glauber, nestas circunstâncias, apresentava-se com uma missão. Era preciso convencer seus interlocutores sobre as trocas de papéis necessárias, em que a substituição de projetos de menor visibilidade por projetos com um enquadramento mais adequado ao que o grupo pensava nos bastidores tornava-se quase um imperativo. Nesta mesma carta enviada a Saraceni, ele chama a atenção do amigo para a necessidade de deixar de lado um suposto lirismo de um projeto de filmagem conhecido como Amor de gente moça. Segundo Glauber, seria, este, um filme que não contribuiria - não naquele momento para criar as condições para que aquela geração pudesse se realizar. Sua justificativa perpassava a solidificação do movimento pelo ímpeto individual de cada um dos projetos:

\footnotetext{
${ }^{52}$ Glauber Rocha, Cartas ao mundo, 1997, p. 164. [carta de jan. 1962, Salvador (BA), endereçada por Glauber a Paulo César Saraceni].
} 
“é preciso formar o movimento. precisamos fazer filmes CERTOS - entendeu? não se pode arriscar, porque se falhamos um segundo, caímos no fracasso. filmes 'LIVRES' só quando a base estiver formada. sei que você (como eu) pode reagir a isto, MAS É A SAIIDA. do contrário ficaremos apenas sonhando, entende? eu sou REALISTA, não tenho ilusões. por isto, Antonioni só me interessa enquanto eu sou intelectual de superestrutura. quando eu faço a redução pro BRASIL SUBDESENVOLVIDO E INCULTO - eu vejo que a Europa é a HISTÓRIA FEITA e nós SOMOS A HISTÓRIA A FAZER, e nosso tempo é pouco, nosso passado é vergonhoso e temos de agir engajados na história. o Brasil de hoje não tem lugar pro artista romântico e sim para o artista revolucionário, mas não um revolucionário da arte e sim da própria história. estética hoje é uma questão política. escreva" 53 .

Decisões tomadas por Glauber também o impulsionavam a assumir mais e mais o seu papel de liderança. Observe-se uma dessas ações. Como forma de tornar o exemplo do grupo e mostrar seu engajamento em relação a um cinema ligado aos assuntos da terra, Glauber, neste mesmo ano de 1962, dá uma de suas cartadas. Recebe do importante, e por ele admirado, crítico Paulo Emílio o projeto de filmar um de seus roteiros originais, o nunca filmado Dina do cavalo branco, cujo roteiro do crítico paulista foi, naquele mesmo ano, agraciado com o prêmio cinematográfico Fabio Prado. Glauber coloca uma série de empecilhos de ordem prática e recusa o tal projeto. Na recusa está uma série de implicações que merecem ser tratadas. A principal delas é o caráter do filme inadequado ao que Glauber e seu grupo delimitavam para os caminhos do cinema em formação. Uma eventual filmagem de um "melodrama popular e moderno para o cinema bahiano", como acusava o subtítulo do roteiro, poderia comprometer, entre outras coisas, a autoridade intelectual de Glauber entre aqueles jovens do movimento. Note-se a resposta em carta a Paulo Emílio, ela demonstra o que pesa em sua decisão: estaria o filme e sua personagem "dentro de uma perspectiva extremamente pessoal e sentimental: a sua, é claro, eu, por meu ângulo, de temperamento excessivamente realista, concebo o mito mas não o sinto pela espinha, como diria fernando pessoa. trata-se de mulher, e eu, confesso, não estou tomado de mulher, mas

\footnotetext{
${ }^{53}$ Glauber Rocha, Cartas ao mundo, 1997, pp. 165-166. [carta de jan. 1962, Salvador (BA), endereçada por Glauber a Paulo César Saraceni].
} 
sim de política. não sei bem se é juventude ou resultado de uma crise violenta e um tanto caótica, surgida justamente por causa de mulher" ${ }^{34}$.

Entre os seus muitos interlocutores, as cartas endereçadas por Gustavo Dahl talvez sejam a que melhor dimensionam o papel que Glauber exerceu entre os seus pares. Sempre muito longas, as cartas de 1963 são ricas em detalhes em referência às movimentações e táticas de atuação do grupo. Contempla-se, entre as demais coisas, o retrato de um Glauber atento aos espaços em festivais europeus para a divulgação de filmes e ideias em torno dos programas planejados. Torna-se clara a preocupação do grupo em lidar com os aparatos do Estado para financiar, com recursos do Itamaraty quase sempre, cópias de filmes ou mesmo passagens para atravessar o Atlântico. Estas cartas também incorporam a admiração do amigo a Glauber e a demonstração afetiva de que o movimento estaria diretamente ligado à disposição do crítico baiano em divulgar e escrever sobre a obra de cada um desses novatos.

É sobre este último detalhe que gostaria de tratar em meu comentário. Em 10 de outubro de 1963, de Paris, Gustavo Dahl escreve algumas páginas para Glauber em que expõe os últimos acontecimentos da presença do Cinema Novo no mundo europeu e nota suas impressões sobre o papel do cineasta baiano dentro do movimento. Segundo Dahl, desde os tempos em que ainda procuravam reunir todos para a construção do Cinema Novo, Glauber teria sido "o único que assumiu o total das responsabilidades. Todos os outros assumiram responsabilidades parciais, todos os outros se ajudavam entre si, mas só você ajudava a todos, quem sabe por isso os outros esqueceram de te ajudar" ${ }^{25}$. Nessa lógica de ideias, Barravento teria sido o filme menos prestigiado publicamente e Glauber como pessoa, e agitador cultural, havia se tornado um mentor mais importante do Cinema Novo, de maior prestígio que o Glauber autor. Sem ainda os impactos de seus filmes posteriores, talvez por conta disso, Gustavo faz uma constatação válida na medida em que atesta uma impressão de liderança do cineasta baiano, uma liderança que ele supõe maior que o próprio cinema deste:

"Tudo isto, Glauber meu, é para explicar uma coisa simples, ninguém lembrou que você, tomando conta dos filmes dos outros, do prestígio de um movimento, sendo ao mesmo tempo seu teórico e seu primeiro-ministro, participando nele ao mesmo tempo como principal autor, e consequentemente acrescentando a todas

\footnotetext{
${ }^{54}$ Glauber Rocha, Cartas ao mundo, 1997, p. 169. [carta de 1962, sem precisão, Salvador (BA), endereçada por Glauber a Paulo Emílio Sales Gomes].

${ }^{55}$ Glauber Rocha, Cartas ao mundo, 1997, p. 219. [carta de 10 out. 1963, Paris, endereçada por Gustavo Dahl a Glauber Rocha].
} 
as inquietações coletivas as tuas particulares, não poderia tomar conta de ti mesmo. Ficaste isolado pela tua posição de chefe" ${ }^{n 6}$.

Por mais que a constatação de Gustavo possa parecer um tanto inocente e mesmo equivocada em alguns momentos, já que os acontecimentos posteriores demonstram que Glauber não havia esquecido tanto assim de seus projetos individuais de autor, suas palavras trazem em si um dado importante na visão de um dos integrantes do grupo. Portanto, uma visão interna aos acontecimentos. Glauber dava a impressão de sobressair aos demais como personalidade pública do Cinema Novo. O homem que vem à praça e faz o comício.

Se esse biênio 1962-1963 pode ser considerado um período de transição para Glauber, que terminou Barravento, projeto assumido às pressas, e ainda iniciou a produção de Deus e o Diabo, além de ter sido o período em que a Bahia deixa de ser o foco principal de sua atuação, passando a ser o Rio, é proveitosa a compreensão do período pela própria militância alcançada por ele. Não é forçoso levantar a questão: foi por ela, por esta militância escrita, que Glauber forjou uma liderança mais racional e segura dentro do próprio grupo? Revisão crítica do cinema brasileiro, seu primeiro livro, amplia as pistas para a questão e suas ideias merecem ser aqui abordadas.

\section{Militância e liderança, pari passu}

Em 1963, na ocasião de publicação de seu primeiro livro Revisão Crítica do Cinema Brasileiro, Glauber Rocha, então com apenas 24 anos, conseguira divulgar de forma mais ampla seu aspecto militante. Mais que isso. Tratava-se de um livro que firmaria sua consagração face duas frações: os jovens intelectuais de cinema, que viam em sua obra uma afinidade e um programa de reconhecimento da nova arte, transformando seu autor e seu livro em liderança e porta-voz do movimento, respectivamente, e os mais velhos, muitos deles críticos de cinema, como foi o caso de Paulo Emílio, que notavam em Revisão um empenho de luta nunca antes visto na história das ideias do nosso cinema. Ainda mais: o livro nascia como uma história notável da vida intelectual de cineastas e críticos de cinema do

\footnotetext{
${ }^{56}$ Glauber Rocha, Cartas ao mundo, 1997, p. 219. [carta de 10 out. 1963, Paris, endereçada por Gustavo Dahl a Glauber Rocha].
} 
momento: um livro-vulcão, um livro, sobretudo, de pura opinião e construção estratégica e ideológica de seu autor.

Depois de coletar artigos baianos e cariocas de periódicos, escrever partes, e repensar um canônico caminho para o cinema brasileiro, seu autor colocara em circulação com Revisão crítica o que representava o balanço de sua militância crítica e os supostos programas do emergente Cinema Novo até o momento, demarcando, explicitamente, os desafetos e os aliados ao tipo de arte que defendia. Talvez esteja aí a razão de o livro se tornar uma estratégia pertinente para sua consagração como jovem intelectual do cinema e da cultura brasileira. Talvez esteja aí sua identificação de vez com os jovens que formavam o grupo do Cinema Novo, principalmente eles.

Glauber parte dos artigos de jornal para se chegar ao formato de livro. Para isso, precisaria integrar uma militância, desde os tempos finais dos anos 1950, com a precisão de compatibilizá-la a uma escrita histórica coesa e totalizadora, como almejava ser um livro daquela natureza. Uma obra que vinha para ao mesmo tempo servir aos interesses práticos do grupo de jovens do cinema e servir como campanha de combate às parcelas intelectuais em desavença.

O crítico Ismail Xavier capta muito bem as forças pelas quais o livro está sujeito. Se nos artigos de jornais, em que o "juízo podia ser mais nuançado" ${ }^{57}$, a atuação militante competia com tantas outras forças, os espaços de ações e recepções do livro eram outros e, por sinal naquele momento, muito mais concentrado em termos de repercussão no meio de intelectuais do cinema. Não é exagero supor que os barulhentos artigos de jornais haviam criado o estofo necessário para que o livro, com seu perfil ambicioso e totalizador, pudesse ser recebido com polêmicas e debates de alta relevância. Basta notar sua recepção crítica no calor da hora ${ }^{58}$.

Diferenças entre uma ação e outra - de jornal e de livro - poderiam ser assim tratadas. Lá nas páginas dos jornais, Glauber poderia admirar certos filmes, mesmo supondo sua inviabilidade de execução entre nós. Tais críticas eram recorrentes em seus textos de periódicos baianos, por exemplo. Diferente, Revisão crítica, com uma natureza de militância e de afirmação de um programa para o Cinema Novo em formação, não comportava

\footnotetext{
${ }^{57}$ Ismail Xavier, "Prefácio" em Glauber Rocha, Revisão crítica do cinema brasileiro, 2003 , p. 8.

${ }^{58}$ Cf. Vários autores, "Fortuna crítica" em Glauber Rocha, Revisão crítica do cinema brasileiro, 2003, pp. 177221.
} 
qualquer descuido e a admiração só é permitida pelo "cinema desejado", aquele que sintetiza ideias para o debate ${ }^{59}$.

Nesse momento, gostaria de dialogar mais de perto com um texto que considero o melhor já escrito sobre Revisão crítica. Dentre as várias perspectivas que o livro já foi abordado, parece bastante adequado iniciar uma interpretação a partir do que o crítico Ismail Xavier escreveu no prefácio à nova edição da obra:

\begin{abstract}
"Olhando o passado, Glauber estabelece o cânone compatível com a nova proposta e instala um tribunal apto a proclamar o que vale como matriz e o que deve ser descartado. Tal postura judicativa encaminha não propriamente um livro de história, mas um texto de crítica empenhado em afirmar um programa para o cinema brasileiro, postura que se exprime na sua típica linguagem de manifesto [...] Como acontece com os líderes de rupturas, ele inventa a tradição que interessa, seja na referência a processos e tendências, seja no destaque dado a personalidades" ${ }^{\prime 60}$.
\end{abstract}

O trecho citado, forte síntese do que representa as condições de produção e de circulação do livro de Glauber, guarda uma série de pontos que precisam ser comentados. Glauber, à época, soma a função de crítico e cineasta. E dentro do seu livro há uma escolha metodológica marcada pela experiência de seu corpo-a-corpo com essas duas funções. Embora não só estas. Quando Glauber, pela visão de crítico, empenhado e militante, imprime sua perspectiva analítica sobre um filme, rejeitando a proposição deste ou aceitando-a, está oferecendo um plano de estratégias do cineasta para outros cineastas. Sua história escrita em Revisão está sempre a trilhar aquilo que é possível, o que já foi feito e o que ainda resta executar, cuja missão o cineasta-autor, apenas ele, poderia conseguir cumprir.

Em Revisão crítica seu autor faz um livro cheio de Cinema Novo. Ele, o Cinema Novo, está por todos os lados. Onde quer que se pise, onde quer que se tateie, lá está ele lembrando um jovem aqui e acolá, uma tradição possível e mais conveniente, uma imagemsíntese de uma história que se escrevia. Em linhas gerais, a adequação dos artigos de jornais ao livro, somado às escritas que concatenam filmes e estilos, configuram um ritmo intenso na história que se quer contar. Assuntos que pulam de um lado ao outro e se ligam uns aos

\footnotetext{
${ }^{59}$ Cf. Ismail Xavier, "Prefácio” em Glauber Rocha, Revisão crítica do cinema brasileiro, 2003, p. 12.

${ }^{60}$ Ismail Xavier, "Prefácio” em Glauber Rocha, Revisão crítica do cinema brasileiro, 2003, p. 11.
} 
outros configuram uma esteira de realizações de homens de um novo cinema, que de Norte a Sul oferecem a tão almejada dimensão nacional ambicionada pelo livro.

Há no livro o empenho de seu autor em construir uma conjuntura histórica conveniente, para isso justapõem-se os cineastas aceitos pelos seus feitos e os rejeitados pelas suas inadequações ao campo das artes em seus respectivos momentos de atuação. Glauber não hesita: entre os cineastas brasileiros de preferência há os de maior preferência. Estes são salientados pela afinidade com as linhas de forças costuradas pela escrita histórica presente no livro. Talvez a história do Cinema Novo, a mais oficial delas, nascesse daí, dessa ligação entre o que fora forjado como linha do tempo, presente em Revisão crítica, e o que se procurou mostrar como a melhor e mais viável opção de cineastas e estilos, para só assim, dentro desses limites, estabelecer um verdadeiro cinema moderno brasileiro em sua representatividade das condições políticas de seus participantes.

Havia dito que os aspectos metodológicos do livro partiam do corpo-a-corpo com o cinema, dadas suas funções de cineasta e crítico. Acrescento a essas duas um outro tipo de experiência mediada pelo cineasta. Refiro-me à sua experiência com a literatura. Embora formado nas cinematecas, sendo ele de boa cultura cinematográfica, como atestam suas inúmeras abordagens de cineastas de variada nacionalidade, Glauber foi também um leitor de nossa literatura. E Revisão crítica não passou incólume a isto.

O crítico Ismail Xavier, neste mesmo prefácio antes citado, havia chamado a atenção para tal empreitada, observando em uma de suas notas de pé de página que "as referências literárias têm um significado que não se reduz ao papel dignificador do cineasta dentro da política cultural conduzida pelo cinema novo e, em especial, por Glauber. [...] Se isto é parte da questão, não está aí o ponto decisivo das relações entre Glauber e os escritores, pois o que teve conseqüência maior foi o conteúdo de sua experiência, a forma como leu e se inspirou" ${ }^{61}$. Quando, em trecho anterior, este mesmo crítico diz que Glauber inventou a "tradição que interessa", por detrás desta afirmação está uma implicação: na tradição inventada para o cinema brasileiro, o cineasta baiano procurou mirar-se na inspiração modernista e recuperar dela uma motivação para uma política cultural ampla e intervencionista. É por isso que não surpreende que no olho do furacão deste debate sobre a configuração de um moderno e novo cinema esteja acima de tudo um estilo de seus cineastas em ajuste aos problemas de formação da nação.

\footnotetext{
${ }^{61}$ Ismail Xavier, "Prefácio” em Glauber Rocha, Revisão crítica do cinema brasileiro, 2003, p. 31.
} 
Em outras palavras, fica patente em Revisão crítica que seu autor sabe, mais que ninguém, nuançar suas experiências literárias, transformando-as em fermento para o debate sobre a formação de um novo cinema, sobretudo em sua seção "política de autores”. Seu olhar recupera o dado local em sua dimensão de estilo, aliado a uma prática de organização criadora na condição de poucos recursos, para cumprir um veredicto: o Cinema Novo recupera a tradição de representar os problemas sociais com estilo próprio, levando-se em conta o impulso autoral de seus realizadores. Aquilo que em outra perspectiva poderia ser considerado o defeito, ganha, nesta nova ordem, o peso de se estabelecer como defesa radical de uma realidade, de uma nova experiência, de uma intervenção. Para explorar melhor a questão, é necessário adentrar as páginas de Revisão crítica. Meu exemplo de lá extraído é Lima Barreto, o cineasta. Antes dos meus comentários cito uma passagem, onde Glauber delineia o perfil do cineasta de $O$ cangaceiro:

\begin{abstract}
"Culturalmente, Lima é um rebento tardio da poesia condoreira de Castro Alves; um nacionalista sensual e caudaloso como Euclides da Cunha, mas sem a cultura e a visão do autor de Os Sertões. Lima é um apaixonado pelo estilo de Euclides; as fortes tintas apenas. Sertanistas como José de Alencar, romântico retardado, sem a profundidade de um José Lins do Rego; sem a vivência deste, cujo suporte memorialista faz do seu romance, apesar da pobreza estrutural e estilística, um verdadeiro movimento de força e comunicação. Ambicionando requintes de expressão, Lima Barreto fica encalhado no parnasianismo de Olavo Bilac. Ideologicamente é místico, espiritualista, ateu e católico, patriota e reacionário, progressista e desenvolvimentista, nem direita nem esquerda, mas também sem a coragem e o talento de um Buñuel para se declarar um anarquista. Um acontecimento brasileiro, um complexo equívoco transformado em mártir e herói como Tiradentes. Esta identificação se reflete em Painel, documentário sobre o duvidoso mural de Portinari, no Colégio de Cataguases, por sinal terra de Humberto Mauro" ${ }^{\prime 2}$.
\end{abstract}

Glauber encontra no uso da comparação com outras artes - principalmente com a nossa canônica literatura - a forma de inserir os feitos dos novos autores do nosso cinema no horizonte de um mundo cultural brasileiro mais amplo. Em sua história projetada ficavam de fora eventuais cineastas que não pudessem ser rapidamente identificados com um mundo das artes e da autoria. Olhando em retrospecto a dinâmica cultural do Brasil, Glauber

\footnotetext{
${ }^{62}$ Glauber Rocha, Revisão crítica do cinema brasileiro, 2003, p. 88.
} 
enxergava em alguns cineastas que o antecediam os lances de um talento individual, sem que isso constituísse o arcabouço de fato para um sistema cinematográfico mais estável, tal como a literatura já gozava. No caso de Lima Barreto, a literatura vem para atestá-lo como um cineasta anacrônico. Os feitos deste em nada, ou quase nada, possuem correspondência com seus contemporâneos mais valorizados de expressões artísticas mais tradicionais. Como bem observou Ismail, Glauber extrai o perfil deste cineasta buscando demonstrar sua falta de "visão histórica" e "postura crítica"63.

Embora Glauber reconheça no cineasta Lima Barreto sua afinidade com certo "nacionalismo verde-amarelo-geográfico" ${ }^{64}$ presente em 1922, tal empatia, no entanto, pouco valor teria frente às novas circunstâncias de produção. A época já é outra e o crítico notaria: "Lima Barreto surgiu tarde" ${ }^{\text {. S }}$ Se ele vê, não de modo positivo, marcas retóricas de um Castro Alves ou de um Euclides da Cunha em Lima Barreto, "as tintas fortes apenas", é porque Glauber enxerga no cineasta de $O$ Cangaceiro um exagero e uma tendência ao monumental. Tão só um legítimo representante de um academicismo que num mundo da arte moderna já poderia ser dado como morto e sepultado. Trata-se, por assim dizer, de uma retórica de esvaziamento das questões de fundo mais pertinentes, em nome de uma ambição por certo requinte de expressão quase sempre mistificadora.

A inspiração de Glauber no livro não é por qualquer modernismo literário. $\mathrm{O}$ autor de Revisão se espelha na sua vertente mais engajada. Não é coincidência que no centro do seu olhar esteja a valoração de exemplares do nosso romance social dos anos 1930 e suas variações posteriores. Graciliano Ramos é a mentalidade em contraponto ao homem de cinema Lima Barreto: "sua obra é desmistificante. Seco, impiedoso, cruel, Graciliano Ramos já tinha retirado os véus da pátria amada: foi parar na cadeia”66. Em sentido contrário, Lima Barreto é o autor da técnica empolada, aquele que, a exemplo de seu documentário Painel (1951) sobre o mural Tiradentes, de Cândido Portinari, orquestra a música heróica em aliança ao "texto vibrante de professor comemorando, ante a ingenuidade da infância, as glórias de Caxias e Deodoro. Um artesanato mecânico, certinho, gramatical, paginando ao gosto da burguesia que, naquele tempo, já gostava de arte moderna e muito mais de

\footnotetext{
${ }^{63}$ Cf. Ismail Xavier, "Prefácio" em Glauber Rocha, Revisão crítica do cinema brasileiro, 2003, p. 14.

${ }^{64}$ Glauber Rocha, Revisão crítica do cinema brasileiro, 2003, p. 90.

${ }^{65}$ Glauber Rocha, Revisão crítica do cinema brasileiro, 2003, p. 90.

${ }^{66}$ Glauber Rocha, Revisão crítica do cinema brasileiro, 2003, p. 89.
} 
Portinari”" ${ }^{\prime 6}$. Como se nota, distinto de Graciliano, Portinari, embora modernista, não é tratado por Glauber com mesma devoção. Com uma interpretação da Inconfidência que compreendia tal fenômeno sob os impasses, tão-somente, das alterações das formas de poder na América Portuguesa sobre as minas de ouro, deixando de ser da alçada portuguesa e passando a ser dos interesses de tais "poetas-juristas", Glauber encara a obra de Portinari, e no mesmo plano o documentário de Lima Barreto, que, ambos, deixam-se escorrer por um falso heroísmo histórico.

Lima Barreto era a mostra do atraso do cinema brasileiro, que chegara ao tema do cangaço apenas em 1953, com O cangaceiro. Chegou, porém, às avessas e sem ter buscado uma interpretação já presente nos romances de cangaços. Fora do tempo, chegou num momento em que o tema já era dominado por completo na literatura mais valorizada pelo crítico: vide José Lins do Rego. Chegou sem compreender os romances populares nordestinos. Seu equívoco foi ter buscado ambientá-lo longe destes mundos e, assim, criou um drama em bases do convencionalismo do filme de aventuras de exaltação romântica. Aquele cangaço tratado no mundo literário era deixado para trás: o "fenômeno de rebeldia místico-anárquica surgido do sistema latifundiário nordestino, agravado pelas secas, não era situado" ${ }^{68}$. Ficavam as matizes das artificiais cores do céu da contraluz de Chick Fowle; ficava o forjado Nordeste nos limites dos estúdios da paulista Vera Cruz; conservava-se o espírito melodramático e o seu lado de facilidades pitorescas, relação com o cinema de massas americano. Em um de seus últimos comentários, Glauber, mais uma vez, o traria dentro dos limites da comparação com a literatura: Lima Barreto transformara-se num digno retumbante do academicismo, digno das láureas do nosso parnasianismo. Um verdadeiro antípoda para os moços do novo cinema.

Com igual energia, porém em outro vetor, ele vai posicionar seus diletos em páginas à frente do livro. Momento em que inicia sua saga sobre a formação do Cinema Novo. A seguir, chamo a atenção para dois cineastas tratados por ele.

Nelson Pereira dos Santos, um pouco mais velho que os jovens da geração de Glauber, é exemplo para todos. O esforço de Rio, 40 graus, no final dos anos 1950, é visto como porta de entrada para o mundo de um cinema brasileiro engajado, uma linhagem de filme social que não era evasivo em sua perspectiva crítica de tratamento do mundo popular.

\footnotetext{
${ }^{67}$ Glauber Rocha, Revisão crítica do cinema brasileiro, 2003, p. 89.

${ }^{68}$ Glauber Rocha, Revisão crítica do cinema brasileiro, 2003, p. 91.
} 
Na perspectiva adotada no livro, trazia-se a lume um tipo de cinema e filme que se trançava à nossa melhor tradição de romancistas. Outra vez, a medida de comparação é o romance social, embora não qualquer um deles. Nelson para o cinema seria comparável a Graciliano: homens que nutriam o desprezo pela forma retórica, homens de retratos "sem retoques de uma realidade cruel" ${ }^{69}$. Se falar do italiano diretor de cinema Luchino Visconti de La terra trema é motivo para trazer à tona o escritor Giovanni Verga, com Nelson em relação a Graciliano as coisas não eram diferentes.

O estilo de Graciliano Ramos tem também sua versão entre os cineastas de mesma idade de Glauber. Paulo Saraceni e seu filme Porto das Caixas foram privilegiados em outra passagem do livro. Afinal, como escreveu em Revisão, "Saraceni ambiciona fazer filmes como se escrevesse romances" ${ }^{\prime 70}$. Isso, todavia, não significaria dizer que o gesto do cineasta se resumiria às suas intenções literárias no fazer dos filmes, espécie de transposição da literatura para as telas. Longe disso. A autenticidade de Saraceni, na perspectiva de Glauber, é resultado da valorização do mundo cinematográfico pela sua própria característica de força de expressão e novidade naquele momento, cujos saldos mais interessantes poderiam ser notados na exploração de valores que antes foram amplamente explorados pela literatura de não muito atrás.

Pelos artigos em jornais do crítico baiano e por seus diálogos em carta, Saraceni já vinha antes sendo sublinhado como um dos grandes talentos entre os mais jovens. Era o caso de Arraial do cabo, o curta-metragem documentário que levou Saraceni à Europa, cuja repercussão apontava-o como um dos representantes de uma nova mentalidade que surgia no cinema brasileiro, um dos principais estouros intelectuais desta nova geração ${ }^{71}$. Era o caso do que dizia aos seus interlocutores epistolares. Em carta a Jean-Claude Bernardet, no mesmo ano de publicação do livro, Glauber chama a atenção do crítico para a figura de Saraceni, definindo-o no seguinte plano: "É um artista, um excelente diretor, sabe a 'mise em scène', vive a 'mise em scène'. É a 'mise em scène', se você me permite"72. Daí para fazê-lo eleito

\footnotetext{
${ }^{69}$ Glauber Rocha, Revisão crítica do cinema brasileiro, 2003, p. 105.

${ }^{70}$ Glauber Rocha, Revisão crítica do cinema brasileiro, 2003, p. 141.

${ }^{71}$ Cf. Glauber Rocha, "Cinema novo e cinema livre", Suplemento Dominical do Jornal do Brasil (SDJB), Rio de Janeiro (RJ), 8 jul. 1961, p. 7; Glauber Rocha, "Arraial, cinema novo e câmara na mão", Suplemento Dominical do Jornal do Brasil (SDJB), Rio de Janeiro (RJ), 12 ago. 1961, p. 4.

${ }^{72}$ Glauber Rocha, Cartas ao mundo, 1997, p. 180. [carta de 1963, Salvador (BA), endereçada por Glauber a JeanClaude Bernardet].
} 
como um legítimo representante do intercâmbio entre o mundo literário e o cinematográfico não foi difícil, como se deve imaginar.

Leve-se em conta que em Revisão crítica o autor aposta na investigação dos estilos de cada um dos seus favoritos. Definir um novo estilo para o cinema brasileiro dependeria de tal investida e estratégia. Com isso em mente, Glauber explorou a qualidade de estilo de Porto das Caixas para a partir dela, a qualidade deste estilo, conectar as duas formas de expressão artística, de dois campos culturais distintos, porém ligados. Veja-se uma das hipóteses reveladas por Glauber. Saraceni, embora com argumento original de Lúcio Cardoso e tendo recebido formação literária deste e de Octavio de Faria, havia realizado uma versão muito pessoal de Angústia de Graciliano. Primeiro, chama a atenção para as abordagens comuns, entre uma e outra obra: "enquanto em Angústia, o pobre e amargurado Luiz da Silva concentra no gordo capitalista Julião Tavares todo o seu ódio e lhe imputa as responsabilidades das desgraças sociais, evoluindo maciçamente para o crime por enforcamento - a mulher de Porto das Caixas procede da mesma forma em relação ao marido"73. Em seguida, o grau de comparação dá-se pelos estilos entre uma e outra arte, criando graus de equivalências entre literatura e cinema: o estilo seco e analítico de Graciliano encontra correspondência no ritmo executado pelo filme de Saraceni que se manteve longe das metáforas fáceis e, num gesto ousado, pôde eliminar o artificialismo do suspense, indicando que haverá, sim, o crime da mulher face ao marido. Em pauta, estava a exploração da mulher, mas não só ela. Institucionalizava-se também a análise daquilo que gerou uma tonalidade ao filme, cuja reciprocidade de relações estava presente na nossa literatura sem artificialismos, saldo de uma alta depuração na relação com sua matéria-prima, a palavra. Caso de Graciliano.

Mesmo que sua aposta recaia sobre a "política de autores" - aliás, ele já delineava tal política em seus artigos de jornais -, o recurso para desvelar o estilo destes autores é atestar, perante a literatura, por meio das comparações e intercâmbios com esta, a significação cultural de cada obra e autor da nova geração de cineastas. Glauber usava sua experiência de mediação com o mundo literário para construir o discurso de relevância e inserção do novo cinema. Tratava-se, entre outras coisas, de um moderno projeto de alavancar a importância da autonomia necessária à nova arte e, assim, divulgá-la em cada

\footnotetext{
${ }^{73}$ Glauber Rocha, Revisão crítica do cinema brasileiro, 2003, p. 141.
} 
beco de um mundo cultural ainda restrito e, de certa forma, conservador para o tipo de empreitada. Curioso notar que, paradoxalmente, enfrentar tal defesa dependeria de sua experiência em outro ramo da cultura. Dependeria o modo como promoveria o debate do cinema brasileiro com ambições artísticas dentro da nossa modernista tradição de literatura, em maior grau, e da nossa tradição pictórica modernista, em menor grau.

\section{O gesto literário: por uma crítica do intelectual empenhado}

Neste momento, gostaria mais uma vez de retomar o texto crítico de Ismail Xavier sobre Revisão. Se até aqui chamei a atenção para a mediação literária, de uma experiência extraída das leituras de Glauber para com o romance social brasileiro moderno, o crítico sublinhará outro caminho para aquela crítica de cinema: acomodavam-se um novo modo de olhar e os desafios para inseri-los, tal crítica e tal cinema, num plano cultural maior e universal. Para ele, o impulso do livro de Glauber, na forma como o problema dos estilos destes novos cineastas se inseriam no complexo da nossa tradição modernista, parte de uma relação com o horizonte poético, com o mundo lírico e com o momento de instauração do poético na formulação das imagens deste cinema brasileiro em ascensão. Não é por menos que ele vá falar em "fragmento que concentra a gema, a verdade do autor"74, quando a miseen-scène afina seus pressupostos com um tipo de poesia de dicção modernista, portanto, antiacademicista.

No plano teórico, a hipótese de Ismail encontra na figura do autor de Barravento um interlocutor propício para recepcionar as noções e os conceitos em torno da lírica divulgados por José Guilherme Merquior, ideias expostas num primeiro momento por este no SDJB, em 25 de fevereiro de 1961, no artigo “A atitude lírica”, e, depois, em 1962, ampliadas no seu ensaio "Crítica, razão e lírica: ensaio para um juízo preparado sobre a nova poesia no Brasil”. O ponto mais decisivo da comparação (e ponto de forte contato) de Glauber com as ideias de Merquior, sob a perspectiva de Ismail, dá-se pelas relações entre lírica e sociedade:

\footnotetext{
${ }^{74}$ Ismail Xavier, "Prefácio” em Glauber Rocha, Revisão crítica do cinema brasileiro, 2003, p. 20.
} 
"[...] há no texto de Merquior uma adesão explícita aos postulados de uma crítica que se afinava ao modernismo em sua visada histórica da formação nacional, e na defesa da percepção estética do real sem exotismos, sem o pitoresco, a empolação e o pedantismo. Por vários flancos, sua concepção de poesia se ajusta à demanda política de Glauber, pois defende uma lírica socialmente empenhada e, no Brasil, associada à evolução de uma consciência de nação"75.

Talvez seja válido notar que a concepção de Ismail, consistente que é em suas interpretações, não invalida alguns pontos antes expostos. O crítico entenderá que o "momento poético" captado pelo olhar glauberiano e, em seguida, transposto por uma leitura dos cineastas e seus estilos, dependerá da apreensão de uma descoberta franca do real, sendo nisso que ele, Ismail, salienta o saldo das prováveis leituras de Merquior por Glauber. Isso, no entanto, não incompatibiliza um dado horizonte de mediação a partir de um tipo de romance social internalizado por Glauber. É possível que a marca e preocupação com o tal real, e, em consequência, suas discussões em torno da nação, estejam pontuadas entre a experiência demarcada da lírica moderna brasileira e a experiência acumulada de romancistas dos anos 1930 e 1940, cuja figura-chave passa a ser em Revisão Graciliano Ramos, um de seus favoritos no momento. Favorito sem sombra de dúvida, pois compatível com as figurações possíveis entre o mundo lírico, sem pompa e exagero, e a sociedade que desejava falar.

Tal compatibilidade, entre a experiência da literatura (tanto da lírica como de um leitor de romances) e o desejo de criar, pelo cinema, um espaço amplo para os debates sobre a atuação intelectual de artistas em nome da defesa da cultural nacional, presente no discurso de Glauber em Revisão, tornou-se fermento para a representação da crise que em pouco tempo atingiria toda a cepa de intelectuais de cinema de sua geração. Seu livro, em certa medida, tornara-se um manifesto para muitos. Se pensarmos na ressonância e transformação dessas ideias em torno da representação literária no contexto das suas práticas intelectuais, talvez não seja exagero supor uma relação com seu filme Terra em transe, que viria a público, em 1967. Embora a conjectura neste caso já esteja dimensionada por outros fatos da vida social brasileira, sendo que o mais marcante deles seja a instauração de uma ditadura militar no país, portanto com um clima de desencanto geral numa fração da intelectualidade esquerda, Glauber não deixou como cineasta de abordar as contradições presentes nas possibilidades de reverberar a força da literatura por um personagem intelectual em atitude

\footnotetext{
${ }^{75}$ Ismail Xavier, “Prefácio” em Glauber Rocha, Revisão crítica do cinema brasileiro, 2003, p. 21.
} 
política, em clara demonstração de que a entrada deste fenômeno artístico continuava a ser parte integrante e essencial de sua vida intelectual e da sua representação do que seja esta mesma vida intelectual. Na representação da crise do intelectual no pós-64 sua opção contemplou a vida literária e política de um de seus principais personagens de Terra em transe. É o caso de se fazer alguns comentários em torno do seu emblemático personagem Paulo Martins - poeta, jornalista e militante. Ele se enquadra como bom exemplo.

Ao acompanharmos a trajetória de Paulo Martins dentro da narrativa de Terra em Transe, em muitos momentos, somos bombardeados pela sua relação com os outros personagens do filme. Sempre conflituosas, estas relações apontam casos de uma situação de condição de dependência, sob a tutela subdesenvolvida, vivenciada pelo personagem. Na representação de Glauber, Paulo Martins sempre necessita resistir ou se ajustar às engrenagens deste mundo de contrastes e rupturas e para isso um de seus parâmetros é seu conflito interno, saldo de sua investida no campo da literatura como poeta socialmente engajado.

Tomemos sua relação com o poderoso Porfírio Diaz.

Paulo Martins não seria o próprio caso de apadrinhamento por parte de Diaz, marca característica desde os tempos da organização colonial, onde fica evidente que o domínio das letras e do poder é reservado aos poucos, e não ao povo?

Reconstituo uma sequência que traz à tona a evidência desta questão, onde o poeta encontra-se na encruzilhada de continuar sob a tutela de Diaz, "o deus da minha juventude”, ou resistir à situação desta condição marcada pela dependência. Trata-se de uma sequência ambientada no palácio barroco de Diaz e procede aquela da reportagem ("Biografia de um aventureiro") de autoria do Paulo Martins, onde ele difama o próprio padrinho.

Início da sequência. A voz over de Paulo, sob o som de metralhadoras e sob as imagens de Diaz, que já não está mais na reportagem, mas no espaço externo do palácio andando de um lado ao outro, inicia a sequência indicando a concomitância de dois sentimentos: "Ele estava morrendo como eu. Estávamos, ambos, sofrendo e, por isto, antes mesmo que ele mandasse me chamar, eu fui vê-lo, carregado de ódio e de remorso". Tais sentimentos definem as forças que moviam o personagem, ao passo que criava um duplo interpretativo das coisas. Não é difícil supor que das duas uma: ou o remorso vinha do arrependimento da reportagem denunciativa contra Diaz ou de sua vontade de nunca ter quisto firmar um pacto com a figura de seu padrinho, alegoria de um poder corrompido e 
que corrompe. Mas e o ódio? Seria ele, da traição ao pai e ao seu compromisso tantas vezes colocado em pauta pelo personagem? De qualquer forma, mais do que supor a quem se dirigi tais sentimentos, é talvez mais importante compreender que arrependimento e ódio nestes contextos fazem-se figuras opostas, que dialetizam as rupturas e os contrastes da condição do poeta no mundo de dependências, como era o seu caso.

Sigamos adiante a mesma sequência para que possamos ter um entendimento maior do ponto de vista adotado na narração e como ele é central para a colocação desta marca do apadrinhamento, próprio da nossa condição de dependência no campo do poder, esta alegorizada no filme.

Do barulho de metralhadoras, surge uma situação de silêncio absoluto e a câmera fecha num primeiro plano, num ângulo de baixo para cima, sobre Paulo, que se encontra sentado num sofá dentro do palácio. Aos poucos, a câmera amplia o seu enquadramento, saindo do poeta e tomando Diaz, de costas, a olhar o suposto apadrinhado na mesma situação do sofá. No mesmo plano-sequência, o movimento de câmera encontrará Diaz frontalmente, agora em mesmo patamar de ângulo. Começará aqui o seu discurso em consonância com a câmera que o acompanha, e não o contrário. A certa altura do discurso, a câmera sairá de Diaz e percorrerá, agora em ângulo de cima para baixo novamente, Paulo Martins, ainda atônito no sofá a ouvir o discurso de ressentimento do padrinho. É quando Diaz aproximará de Paulo e levantará a questão: “O que são os interesses políticos diante da amizade?". Muda-se o plano, agora estão os dois personagens ambientados em meio aos luxos do palácio num enquadramento de meio-conjunto. Diaz se levanta, continuará o discurso, e mais uma vez ganhará prioridade no enquadramento, que se afastará da figura de Paulo. Diaz longe de Paulo continua o monólogo e, num movimento de volta, com a câmera somente em Diaz, os dois personagens voltam a se aproximar. Agora, o silêncio, entre as falas, não é mais absoluto; inicia-se uma trilha sonora, que se intensificará dali ao fim da sequência. Em corte brusco, um primeiro plano enquadra a arma empunhada por Diaz e apontada para a cabeça de Paulo. Na mesma cena, a pergunta a este último parece acordá-lo do dilema: "Onde está a sua consciência?", que se afasta de Diaz gritando: "Nem que você me desse todo o ouro do mundo!”. Dali começaria o corpo a corpo dos dois personagens e o rompimento do poeta com toda aquela situação, marcada pelo apadrinhamento (e a força deste demonstrada na linguagem fílmica pelos enquadramentos de superioridade de Diaz em 
relação à situação de Paulo no espaço interno do palácio) e pela resistência a esta realidade. Resistente à situação de apadrinhamento, restaria a Paulo o apoio ao líder populista Vieira.

Essa foi uma das faces do jogo político enfrentado pelo personagem.

Que relações tirar desse enfrentamento? Já que Paulo Martins é, antes de mais nada, um poeta, que lições estariam arraigadas à figura do poeta nessas circunstâncias de rompimento? Será que a figura do poeta sai ilesa do jogo político, de supostos tratos com a classe dirigente? Nisso haveria uma crítica introjetada em Terra em transe ao intelectual engajado, que, em última instância, dada sua ligação com os donos do poder, não seria tão independente assim como se poderia supor?

Antes de comentar tais questões, é preciso saltar para o início do filme e notar mais alguns passos do personagem. Pode nos ajudar a compreender de forma mais ampla tal imbróglio. As primeiras palavras de Paulo dirigidas à Sara anunciam uma situação que o filme, na volta ao passado, ainda iria revelar: "Está vendo, Sara, quem era o nosso líder? O nosso grande líder?”. Os desencadeamentos dos conflitos mostrariam que Paulo se frustrara, mais uma vez, com os jogos políticos de Eldorado, sendo que a queda de Vieira, logo no início do filme, é também a sua própria derrocada.

Logo após a renúncia de Vieira, Paulo e Sara sairiam em alta velocidade por uma estrada asfaltada; dentro do carro, os seus diálogos indicavam que a luta chegava ao fim. Se para Paulo a luta de Vieira e sua resistência à renúncia provariam muita coisa, para Sara representaria a morte de muitos, a própria loucura. Uma loucura que em Paulo tornaria a razão de resistir, “a hora da decisão, na luta, mesmo na certeza da morte!”.

É da já referida derrocada, com Paulo cambaleando nas dunas após ser atingido por tiros de policiais, que se dá o salto ao flashback, fazendo-o com que analise, liricize em alguns momentos, aquilo que agonizou sua vida e ainda o agoniza. É a sua última centelha de resistência, de uma articulação dada entre a tensão dos fatos de Eldorado e o ímpeto motivador do poeta, cuja falha, tal como Mário Faustino estabelece com seus versos lançados à tela, é a de "não conseguir firmar o nobre pacto".

Tomemos mais de perto, para o momento, os lances da volta ao passado. Os encontros de Paulo com os outros personagens pautam a dimensão narrativa deste jogo: nele sempre ele está na encruzilhada da luta pela revolução e do jogo político de amarras do mundo "subdesenvolvido". Sua situação de poeta é que o coloca nas contradições e dilemas, numa clara aposta e alusão de Glauber, por intermédio da alegoria, na viabilidade de 
representar o intelectual brasileiro dentro da tradição modernista em sua relação estreita com o mundo literário e político de origem. Analisando por outros termos, trata-se de uma questão que não deixa de refletir a própria situação de seu autor e cujas linhas já se esboçavam em seu primeiro livro.

Voltando à situação do personagem, é Sara quem chama Paulo à luta política. Ela o procura na redação do "Aurora Livre, o jornal independente e noticioso" onde ele estava trabalhando após o primeiro rompimento com o apadrinhamento de Diaz. Munido de fotos das misérias de Eldorado, Paulo é convencido de que é preciso agir e de imediato ele pensa que a figura de um líder é necessária. Os acertos viriam com Vieira, o candidato ao governo da Província de Alecrim.

Mais do que os momentos de alianças felizes entre Paulo e Vieira, os momentos de rupturas dos dois são mais sintomáticos dos duplos inconciliáveis do poeta. O primeiro rompimento, dentro do flashback, vem logo depois da vitória de Vieira para o governo. É neste rompimento que conseguiremos visualizar a primeira via contraditória de Paulo, revelada pelo narrador fílmico que vezes se utiliza dos diálogos dos personagens, ora intercalando uma montagem fílmica com vistas a um projeto de desnudamento das palavras e as supostas ações que dela advém.

A sequência mostra o encontro de Vieira com Felício, um homem do povo e pobre camponês. Tomemos o seu espaço cênico. As duas instâncias, a do povo e a dos políticos e seus aliados, são ressaltadas pela montagem. Se, por um lado, Paulo e um militante, representantes de uma elite política, estão acima do morro, posição também ocupada por Vieira, que sai do seu Cadillac e olha em direção à parte mais baixa do cenário, será, por outro lado, debaixo do morro que surgirá Felício. A câmera, num plano conjunto, tomará o camponês de costas subindo o morro e sete policiais descendo em sua direção. $\mathrm{O}$ corte segue para um plano em que Felício se aproxima do governador e expõe os problemas de suas terras: "é que nossas família chegou nessas terra já tem mais de vinte ano e a gente lavrou a terra, plantou nela e as mulher da gente pariu nessas terra. Agora a gente num pode deixar as terra só porque apareceu uns dono num sei daonde trazendo um papel do cartório e dizendo que as terra é dele...É isto que eu queria dizer, seu doutor...A gente acredita no sinhô, mas se a Justiça decidir que a gente deve deixar as terra, a gente morre mas num deixa não". Paulo intervém, após claro sinal da cabeça (em plano anterior) do governador indicando ordem, e reprime Felício, empurrando-o ao chão, repreendendo-o: "Se acalme, Felício, 
respeite o governador". Estaria Paulo fazendo o jogo político de Vieira? Ou seria apenas uma provocação aos homens do povo? Parece-nos que as afirmações para as duas questões são garantidas no plano narrativo do filme. Numa outra sequência, em que o poeta desabafa à Sara o seu ato, vai dizer: "E eu fui lá, bati num pobre camponês porque ele me ameaçou...Podia ter metido a enxada na minha cabeça, mas ele era tão covarde e tão servil! E eu queria provar que ele era covarde e servil...A fraqueza...gente fraca...sempre...gente fraca e com medo...". Se, ao menos nos jogos das palavras, Paulo revelou uma certa tentativa de mobilizar o povo, mesmo que, para tanto, precisasse colocar a sua própria vida em risco, a montagem fílmica revelaria um dado narrativo que poderíamos afirmar também que Paulo participava do jogo político naquele instante. Embora tratasse de uma ação contraditória por parte do poeta. Primeiramente, o olhar do político na arquitetura cênica revelaria o comprometimento de Paulo com as amarras políticas, ao menos naquele momento. Posteriormente, mais adiante no filme, entre suas falas de desabafo à Sara, no momento em que critica os atos de Vieira dizendo "vai repelir os agitadores", perpassa, na forma de um flash, uma cena do poeta de capa preta e com os braços abertos dispersando a multidão. Cena que pode ser representativa, como Ismail Xavier muito bem nos colocou, em seu livro Alegorias do subdesenvolvimento, de uma imagem recalcada, denunciando, por meio da montagem fílmica, contradições do poeta: "o que a voz de Paulo atribui a Vieira, a imagem atribui a ele próprio como espelho do governador"76.

O encontro de Paulo com Sara nos jardins do palácio de Alecrim também revela estas marcas de encruzilhada na caminhada do poeta. É o caso de notarmos o diálogo entre os dois: Sara colocará que para ela não valem as "ambições normais de uma mulher normal”, mas aquelas em termos coletivos, algo maior do que a lógica dos seus sentimentos. E ela dirá: "de que outras ambições individuais posso falar que não seja a de felicidade entre pessoas solidárias e felizes?". Paulo responderá a "fome do absoluto", ou seja, aquela em que irrompe com todos e com tudo, "sacrificando as mais fundas ambições". Diante do caminho tortuoso, restaria a Paulo a fissão do homem.

Do jardim, saltamos para o abraço dos personagens no espaço do apartamento de Paulo. Refletem-se ainda os mesmos dilemas da sequência anterior. Para Sara "um homem não podia dividir assim, a política e a poesia são demais pra um só homem”. Já para Paulo, vivendo as notícias amargas de seu mundo, não se poderia anunciar nenhum tipo de

\footnotetext{
${ }^{76}$ Ismail Xavier, Alegorias do subdesenvolvimento, 1993. p. 37.
} 
estabilização do mundo de dependência política e de poder onde ele atuava. A fala final de Paulo nesta sequência era reveladora do momento e de suas contradições de sentimentos: "A poesia não tem sentido... Palavras... As palavras são inúteis...”.

É próprio do mundo de Paulo Martins a poesia. Tudo leva a crer que sem ela, o personagem não seria arrebatado como foi; sem ela não se projetaria quaisquer forças intelectuais com implicações tão decisivas como foi. Se eu trouxe Paulo Martins na sua luta para se desapegar ao seu apadrinhamento, espécie de alegoria dos conflitos de poder existentes no seio social brasileiro, ou se trouxe Paulo Martins em situação de contradição interna buscando refrear o homem do povo ao mesmo tempo em que faz a própria punição, arrependimento e alerta de luta do povo à Sara, sua companheira, foi para atestar uma ramificação presente em Terra em transe, cuja raiz já poderia ser apreciada em Revisão crítica. Tanto no livro, como no filme, Glauber exercita o ensaio sobre a força da literatura na formação dos intelectuais na vida social brasileira e que poderia ser estendida ao contexto latino-americano em plena ebulição. Seja pela crítica desembocada numa história forjada ao seu bel-entender, caso do livro, seja pela crítica ao mundo intelectual instituído sob as bases da construção de seu principal personagem ficcional no filme, a literatura não deixa de acompanhá-los, lembrando, sempre que necessário, que é desta tradição que toda discussão é gerada.

Em Revisão crítica, Glauber coloca em crise cineastas e obras que não convinham na sua história da formação de um cinema de autores no Brasil. Por isso, a literatura presta-se para demonstrações de que tais cineastas, embora muitos deles com sucesso industrial, exemplo de Lima Barreto, experimentavam uma espécie de anacronismo em relação ao mundo moderno das artes, em geral, e, em termos específicos, com a literatura de inspiração modernista. De outro lado, ele complementa também salientando a literatura moderna como a base de comparação mais compatível aos seus melhores exemplos. Nestes, Glauber não deixa por menos e encontra correspondência com nossos melhores poetas e romancistas. Em Terra em transe, já com um contexto cultural adverso e muito distinto daquela condição que foi caracterizada a feitura do livro, a figura construída de Paulo Martins avança para um dilema. É poeta e sua lírica está enviesada numa representação do mundo social sem a retórica do exotismo e da vida pitoresca das cores e sons dos trópicos. Muito pelo contrário, a lírica de Paulo Martins que temos acesso está em constante conflito com a face pobre deste mundo. É por meio dos seus poemas, pelos quais acompanhamos em camadas de narração 
do filme em suas várias declamações intercaladas ao longo deste, que encaramos o travo indigesto de um tipo de poesia pessimista presente no mundo intelectual do personagem. Verifique-se um destes exemplos. Em meio à famosa sequência do "Encontro de um líder com o povo" um destes momentos de marcação lírica do personagem pode ser notada na declamação com ares dramáticos:

"Qual o sentido da coerência?

Dizem que é prudente observar a História sem sofrer.

Até que um dia, pela consciência,

A massa tome o poder...

Ando pelas ruas e vejo o povo magro, apático, abatido.

Este povo não pode acreditar em nenhum partido.

Este povo alquebrado, cujo sangue sem vigor,

Este povo precisa da morte mais do que se possa supor.

O sangue que estimula meu irmão à dor,

O sentimento do nada que gera o amor,

A morte como fé, não como temor".

Paulo Martins como poeta mantém uma relação de conflitos com a realidade e as formas de ação do intelectual com vistas às transformações sociais desejadas. Se esta relação pelas suas palavras é em tal ponto conflituosa, chegando até mesmo a colocar o seu fazer literário sob suspeita (afinal, do que serviriam as palavras diante da fome do povo?), em contrapartida, é também em virtude dos poemas de Paulo Martins, muitas vezes com papel de comentador dos fatos e ações na narrativa, que se abre uma brecha para a reflexão crítica dos anseios populares.

Glauber como autor quer deixar claro: a face que francamente a esquerda poderia apoiar em Paulo Martins é o seu lado de homem da poesia, de homem que alcança a plenitude de uma resistência pela força das suas palavras. É desta representação que Glauber quer deixar a lição pedagógica para a atuação prática no mundo real. O que não é nenhuma surpresa, se pensarmos que em Revisão Glauber, como crítico, vai notar que o caminho de ambientação do autor se faz também pela mediação da experiência literária, dando à literatura um peso maior do que possa supor na formação dos autores e nos filmes do Cinema Novo. 
Não é nenhuma surpresa também que a literatura se rearranje não só em Glauber, mas que outros cineastas sirvam-se dela para formular os personagens intelectuais de seus filmes.

Jean-Claude Bernardet, em seu livro Historiografia clássica do cinema brasileiro, chamou a atenção para os casos dos filmes Desafio, de Saraceni, o próprio Terra em transe, de Glauber e Os inconfidentes, de Joaquim Pedro de Andrade. São filmes que, embora criem relações de conflito ou de ironia com o literário, não representam, todavia, "uma crítica convincente da literatura"77. Afinal, "a literatura é questionada na diegese, não como matériaprima para a elaboração do filme"78.

Voltando ao exemplo exclusivo de Glauber.

Livro ou filme, em ambos os casos, é possível detectar a representação de um intelectual padrão que seu autor se empenha em mostrar didaticamente no correr das penas ou no correr do seu olhar no jogo de luz e som das câmeras.

Há um programa de atuação para o intelectual que tomasse o livro do cineasta baiano como lição e esperança: é preciso seguir a tradição modernista; é preciso pensar numa política de autores; é preciso acomodar um cinema que esteja afeito à nossa melhor lírica e à nossa prosa mais rica, sem esquecer a necessidade de discussão dos principais problemas da vida social brasileira, as características da verdadeira nação e suas assimetrias sociais, marcas de nossa condição subdesenvolvida.

No filme, o clima não é tão esperançoso assim; existe a crítica ao seu personagem intelectual que, mesmo empenhado em fazer um tipo de poesia social, não consegue se livrar dos arranjos políticos de Alecrim e se sucumbe. Fica, por outro lado, uma cifrada lição: é preciso resistir dentro da engrenagem. Não sucumbir e resistir a cair na imensidão das dunas. Fazer o estilo de Paulo Martins por um dos lados, esquecendo-se do outro, por assim dizer. Em suma, Glauber sabia que o movimento do Cinema Novo sofria o influxo da literatura. Para valorizá-lo, o movimento, não seria má ideia valorizar a tradição literária moderna.

\footnotetext{
${ }^{77}$ Jean-Claude Bernardet, Historiografia clássica do cinema brasileiro, 1995, p. 156.

${ }^{78}$ Jean-Claude Bernardet, Historiografia clássica do cinema brasileiro, 1995, p. 156.
} 


\section{Glauber aqui de dentro e lá de fora, um homem sem profissão: especial para $O$ Pasquim}

Ao longo dos anos 1960, com maior evidência talvez da segunda metade para frente, Glauber se empenhou no sentido de tornar-se amplamente conhecido no âmbito internacional. Percorria festivais, ora defendendo obras próprias ou de outros brasileiros, ora ofertando aos europeus, com uma boa dose de sua peculiar polêmica, novas ideias geradas no âmbito da condição de intelectual subdesenvolvido, como gostava de frisar; na Itália e na França, sobretudo, soube estabelecer contatos com veículos de comunicação com boa reputação no meio cinematográfico, não raro conseguindo emplacar depoimentos acalorados em páginas de jornais e revistas especializadas; sua agressividade nas palavras despertava interesse de artistas e críticos europeus para uma real aproximação e, quando da amizade efetivada, de sua parte, ele mantinha com ímpeto a rede de relações, estivesse lá ou aqui, pelo uso contínuo de cartas - tratava-se de um correspondente contumaz. A seu favor, ainda conseguiu circular na Europa, num curto período de três anos, dois excelentes filmes seus (Deus e o diabo na terra do sol e Terra em transe), sem contar ainda o sucesso que viria no final da década com $O$ dragão da maldade contra o santo guerreiro, fatores, todos estes, que elevariam ainda mais seu prestígio durante a década. De modo geral, elegiam-no como o principal representante do Cinema Novo.

O plano permanente de sua internacionalização como intelectual desemboca nas constantes viagens e nos projetos comuns em parceria com outros intelectuais e produtores europeus, além, é claro, de períodos de estadias longas na Europa, Estados Unidos e Cuba. Facilitavam-se, nesse sentido e dentro destas circunstâncias de prestígio, as condições adequadas para suas experiências futuras, o início de sua época de maior exílio do Brasil, entre os anos de 1971 e 1976.

Não é preciso, porém, chegar à década de 1970 para verificar sua atenção dirigida aos jogos do novo ambiente intelectual e internacional. Quando se acompanham suas cartas do final da década de 1960, é visível a preocupação de Glauber em corresponder-se com um número cada vez maior de figurões de boa influência nestes países: produtores, diretores, críticos, distribuidores, intelectuais. Sem chegar a substituir seus escudeiros de Cinema Novo ou a conversa com críticos que iniciavam a publicação dos primeiros livros sobre o movimento por aqui (caso, por exemplo, de Jean-Claude Bernardet), na maior parte dos seus 
diálogos epistolares, ele canaliza suas energias para demonstrar a viabilidade dos novos projetos em co-produção e trazê-los à esteira do que mais agradava ao europeu, a unidade política de um movimento de resistência: quando uma de suas ideias era recusada, lá estava ele com outra proposta, demonstrando um vigor intelectual sem igual.

À época, dada as dificuldades para novas produções no Brasil, Glauber fazia notar sua insatisfação de aqui estar e sempre sinalizava aos seus interlocutores internacionais o desejo de traçar outros projetos em outras terras. Recado dado, seus interlocutores não demoravam a fornecer-lhe uma resposta acolhedora, quando não convites surgiam. Não é incomum mensagens como a de Daniel Talbot, distribuidor de filmes independentes em Nova York: "Sempre reflito no problema da sua vida no Brasil; imagino ser tediosa... mas acho que você é um homem 'internacional' - não um desenraizado - e por isso você pode viver com homens e mulheres de qualquer lugar; é um dom muito especial"79. Não é incomum mensagens como a de Michel Ciment, crítico de cinema da revista Positif. “pensamos em vocês mais de uma vez e uma das grandes alegrias do ano passado foi conhecê-lo" ${ }^{80}$. Não é incomum mensagens como a de Pere Fages, produtor espanhol: "He recebido tu carta y la sinopsis. La he leido atentamente. El guión me parece espléndido, y además que hás sabido dar en los puntos realmente claves para que el film, al tiempo que uma obra muy personal, interprete muy certeramente cirtos aspectos de la realidad española" ${ }^{81}$. Não é incomum mensagens como a de Harry Stone, representante no setor de filmes dos interesses norte-americanos no Brasil, o qual Glauber havia criticado no início da década: "Fiquei muito feliz em saber do recente sucesso obtido por você e um grupo de diretores e produtores quando estiveram em New York. Também li com entusiasmo sobre o seu talento ter sido descoberto também por Elia Kazan. Nesse sentido, estou certo de que sua opinião atual difere um tanto daquela publicada no Jornal da Semana, em Salvador, em 2 de dezembro de $1961 " 82$.

Naquele final dos anos 1960, a Europa para Glauber transformara-se em privilegiado púlpito. Deste fez proveito e lançou-se como a principal voz do intelectual do

\footnotetext{
${ }^{79}$ Glauber Rocha, Cartas ao mundo, 1997, p. 339. [carta de 17 abr. 1969, Nova York (EUA), endereçada por Daniel Talbot a Glauber].

${ }^{80}$ Glauber Rocha, Cartas ao mundo, 1997, p. 314. [carta de 9 abr. 1968, Megève (França), endereçada por Michel Ciment a Glauber].

${ }^{81}$ Glauber Rocha, Cartas ao mundo, 1997, p. 341. [carta de 6 jun. 1969, Barcelona (Espanha), endereçada por Pere Fages a Glauber].

${ }^{82}$ Glauber Rocha, Cartas ao mundo, 1997, pp. 326-327. [carta de 11 nov. 1968, Rio de Janeiro (RJ), endereçada por Harry Stone a Glauber].
} 
terceiro mundo. Havia casos de textos que começavam a circular por lá primeiro, para somente depois receber a ambientação para o público nacional. Na mesma medida, é interessante notar as formas de recepção do seu ideário na França, um país, como se sabe, que acolhia a esquerda brasileira dissidente. O pesquisador Alexandre Figuerôa, que se deteve na análise da recepção do Cinema Novo pela crítica cinematográfica francesa, notou tanto os pontos que aglutinavam as ideias do movimento deste novo cinema à parcela de uma crítica francesa militante, quanto os pontos que depois os separaram. Tal ligação, para ele, se inicia com a politização da crítica cinematográfica francesa que logo se guiou por um sistema de signos políticos, encontrando nos filmes brasileiros, estes sempre se dizendo portadores de um projeto ambicioso de transformação da realidade mais dura, um perfeito casamento de assuntos e disposições ${ }^{83}$. Por trás disso, entretanto, estava uma intenção, esta observada pelo historiador: "a crítica permitia-se, dali por diante, ampliar suas estratégias: servir-se do cinema para se atribuir a missão de ser, também ela, porta-voz das forças revolucionárias" ${ }^{4}$. De uma crítica europeia de esquerda com clara disposição em opor-se à marca de um cinema imperialista, isto é, um cinema de Hollywood, vinha uma aderência às perspectivas políticas e éticas trazidas por este novo cinema gerado nos trópicos, seu caráter de oposição ao mundo capitalista $^{85}$.

O caso de Glauber levantado pelo pesquisador é exemplar. A recepção inicial de sua obra e de suas palavras por frações engajadas de adoradores franceses alçava-o ao representante modelo de uma forma de cinema tão desejada, de um tipo de cinema que até mesmo mudaria a perspectiva de abordagem desta mesma crítica. Com o cinema agora seria possível fazer militância política, diziam alguns. É evidente que, dentro desta dinâmica, Glauber soube apostar como ninguém. Soube dizer, sem receio, o que interessava aos ouvidos franceses (e italianos) no momento. Mesmo em situações em que ele criticava o hemisfério norte como um todo, deixava-se entender pelas entrelinhas que o principal alvo era o imperialismo cultural norte-americano e o seu suposto cinema burguês e pouco engajado. As falas de suas entrevistas e de suas declarações transpareceriam uma unidade ao movimento do Cinema Novo, não obstante a heterogeneidade das divergências estéticas. É como se todos

\footnotetext{
${ }^{83}$ Cf. Alexandre Figuerôa, Cinema novo: a onda do jovem cinema e sua recepção na França, 2004, p. 161.

${ }^{84}$ Alexandre Figuerôa, Cinema novo: a onda do jovem cinema e sua recepção na França, 2004, p. 161.

${ }^{85}$ Cf. Alexandre Figuerôa, Cinema novo: a onda do jovem cinema e sua recepção na França, 2004, pp. 162-163.
} 
estivessem ligados por uma mesma ação política, registrava o cineasta baiano nos veículos franceses.

Por sinal, bem recepcionada na Europa por alguns, sua estratégia para se alongar neste raio de ideias foi encontrar não só motivações para a defesa de um Brasil e de sua realidade em contraposição à influência dos Estados Unidos, mas uma forma que levasse este espírito revolucionário de pregação para um âmbito de atuação mais ambicioso: a participação dos três continentes subdesenvolvidos - América Latina, Ásia e África - era parte do seu projeto. Se a inspiração mais imediata era Che Guevara e sua Mensaje a los pueblos del mundo a través de la Tricontinental (1967), Glauber proclama o cinema como a forma de luta dos três continentes, elegendo, para tanto, os próprios problemas, a miséria e as condições de pobreza integrantes dessa representação de resistência que se dizia revolucionária. Tais características, condições e contradições da perspectiva histórica do período já começam a ser investigadas. Com certo protagonismo, é preciso apontar a tese de Maurício Cardoso, O cinema tricontinental de Glauber Rocha, de 2007, pois estabelece as conexões necessárias entre o programa estético e político do cinema tricontinental para esclarecer a atuação de Glauber durante o seu exílio ${ }^{86}$, cujo momento posterior, por volta de 1970-1971, fora de depreciação do seu prestígio alcançado até ali.

Desse final de decênio, antes, importa saber que a boa recepção em Cannes, em 1969, com o Dragão da maldade contra o santo guerreiro, dando-lhe a premiação de melhor direção no evento, selaria seu momento de consagração na Europa, momento, este, de devoção por parcela de críticos e intelectuais do velho mundo. Inclua-se tal fato como impulso para seus projetos internacionais. Glauber não demoraria a começar suas primeiras produções europeias, muitas delas baseadas nesta agenda de cinema tricontinental: Cabezas cortadas, na Espanha, e O leão de sete cabeças, filmado na África, com produção do francês Claude-Antoine - saldo de convites estrangeiros e aposta ousada e cheia de esperança em se tornar o mais influente intelectual da América Latina. E da mesma maneira que Glauber foi o cineasta latino-americano mais lembrado pela crítica especializada europeia de fins dos anos 1960, veio o seu declínio em termos de prestígio. Esta, entretanto, é outra história e deve-se ao resultado das amargas recepções em torno destes dois primeiros filmes em co-produção europeia.

\footnotetext{
${ }^{86}$ Cf. Maurício Cardoso, O cinema tricontinental de Glauber Rocha: política, estética e revolução (1969-1974), 2007.
} 
Em outro sentido, talvez seja o caso de perguntar sobre a atuação de Glauber por aqui nesta mesma época. Sabendo de seu investimento na carreira profissional de caráter internacional e de suas constantes viagens fora do país numa época em que não fizera aqui nem lá seu endereço fixo, quais seriam seus traços de pensamento no momento? Quais textos e por onde se trançavam os fios das ideias para o mercado interno? A resposta pode estar nas suas colaborações n' O Pasquim, já que elas refletem o momento de desencantos, esperanças e motivações vividos por ele naquele agitado fim de decênio.

Buscando caracterizar esta sua nova face de colaborador, digo de antemão, sem ainda demonstrar isso, que Glauber Rocha, nesta mesma época e por aqui, foi um escritor de ideias radicais e será nesta figura que vou me deter de agora em diante, numa tentativa de investigação dos traços deste pensamento.

Primeiro é preciso indicar meus pressupostos do que considero radical.

Radical é, com base no conceito formulado por Antonio Candido no artigo Radicalismos, um modo de promover um contrapeso ao movimento conservador que sempre foi determinante em nossa realidade. Os problemas sociais mais urgentes de nossa sociedade são os estímulos necessários para que o radical se faça existir e assim transforme o que é revolta interna em reação progressista. No caso do intelectual radical, esta reação pode ser percebida pela materialização e força de empenho das suas palavras. A escrita do radical está carregada dos vestígios que caracterizam a tensão entre sua posição social de classe - de origem média ou de setores de classe dominante - e a contribuição para uma eventual ação revolucionária, sem necessariamente ser um pensamento revolucionário. Antonio Candido explica que em países como o nosso, em que pesem as condições de desigualdade social e econômica e que a consciência política do povo não está diretamente aliada ao que é potencialidade revolucionária, "o radical pode assumir papel relevante para suscitar e desenvolver esta consciência e para definir as medidas progressistas as mais avançadas possíveis. Digamos que ele pode tornar-se um agente do possível mais avançado" ${ }^{\circledR 7}$.

Assumir Glauber Rocha como um radical é reconhecer que estes seus escritos d'O Pasquim podem assumir este papel de relevo no cenário de onde emergem. Veículo de imprensa alternativa dos mais importantes e atuantes no Brasil da ditadura, O Pasquim procurou pela via do humor contestar a prática conservadora, ao menos até o seu limite do possível. As colaborações de Glauber iniciam nos primeiros anos de 1970, mesma época dos

\footnotetext{
${ }^{87}$ Antonio Candido, "Radicalismos” em Vários escritos, 2004, p. 195.
} 
trabalhos na Europa com o filme Cabezas Cortadas, e se estendem até 1977, totalizando dezenas de textos críticos.

O radicalismo de Glauber ao compor seus textos para o veículo gira em torno dos movimentos de ataque e de defesa, sejam de personalidades intelectuais e literárias do país, sejam de ideários estéticos e políticos. Por este caminho é que tentaremos abordar os textos do periódico. Alguns exemplos parecem bastante modelares desta constituição. Discutiremos dois deles, um de 1970 e outro de 1972. O primeiro é o ataque direto à personalidade política e intelectual, no caso de Carlos Lacerda; o segundo, mais próximo ao manifesto, a intelectualidade e as lutas estéticas e políticas, e com elas os termos explicativos do capitalismo de então, são o foco principal. É, este último caso, uma clara aproximação às ideias que Glauber divulgava no ambiente estrangeiro. É o que veremos a seguir.

\section{"O barato do Lacerda"}

Na militância crítica de Glauber é comum encontrar em seus textos a nomeação dos desafetos e aliados às suas ideias. Com tal prática, a um só golpe, ele polarizava suas posições políticas entre apoiadores e detratores. O que já não é pouco em ousadia. A estratégia quase sempre se mostrava tal como uma faca de dois gumes, ora, por um lado, apresentando-se viável e eficaz para seus interesses, ora, por outro, apresentando-se pouco ou nada certeira, um tiro no próprio pé que atrapalharia planos futuros.

Retomando este corriqueiro ângulo combativo e nomeando um de seus inimigos, o texto "O barato do Lacerda (não ficção, interartigo, duplifarsa, óleo de rícino, ensaitixix, etc.)", publicado n'O Pasquim, de 5 de março de 1970, é sem sombra de dúvida exemplo disso. Antes, porém, é preciso entender as condições pelas quais o artigo é produzido. Sua gênese está em outro artigo, publicado no jornal Última Hora dias antes, em 27 de fevereiro daquele mesmo ano, em que ele responde provocações do político carioca lançadas na imprensa. Na ocasião e sem grandes novidades, Glauber mais uma vez defende o caráter descolonizador do Cinema Novo e sua militância em prol de um mercado interno estável. Em outras palavras, o Cinema Novo, segundo ele, ao mesmo tempo em que não utilizava fórmulas do cinema estrangeiro, em especial o norte-americano, ele também procurava uma viabilização de um público, fazendo disso uma luta severa frente aos distribuidores e 
negociantes internacionais. Não deixa de ser curioso, e talvez irônico, saber que este mesmo grupo criticado por Lacerda fora também o grupo por ele privilegiado nas premiações e incentivos por meio dos recursos da Comissão de Auxílio à Indústria Cinematográfica (CAIC), agência criada em pleno governo de Lacerda, em 1963, no então estado da Guanabara. Em 1970, em nova conjuntura, entretanto, Glauber vê em Lacerda um representante dos interesses estrangeiros, um justo inimigo do cinema nacional, ajustandolhe uma crítica a partir desta suposição:

"Este grupo antigo da Vera Cruz e os herdeiros atuais são alguns dos assessores cinematográficos de Lacerda. Atrás do artigo que Lacerda publicou, atacando desesperadamente o cinema brasileiro, está o dedo de Hollywood e de vários distribuidores e exibidores interessados na ruína do cinema brasileiro. Um dos meios de destorcer os verdadeiros problemas do nosso cinema e promover sua desmoralização artística e cultural. Utilizar um demagogo popular como Lacerda para um destes números de circo é um golpe calculado. E a prova de que Lacerda tem interesse nisto é que ele está querendo se meter na importação de filmes e mais de uma vez mandou alguns de seus pombos correio sondar simpatias minhas e de alguns outros produtores para seus projetos. Os produtores que sofrem na carne a colonização econômica e cultural do cinema brasileiro não querem importar filmes, mas sim LIBERTAR O MERCADO BRASILEIRO DA IMPORTAÇÃO DESENFREADA"88.

Talvez não satisfeito com a resposta que tenha publicado no jornal Última Hora, ele vai mais a fundo na desqualificação de Carlos Lacerda político e crítico de jornal, esquentando ainda mais a polêmica. Parte por um humor corrosivo, ácido e sempre disposto a veicular uma autoridade intelectual de sua parte maior que se possa supor a do seu criticado.

Cabe conferir.

Como o próprio título indica, o desafeto de Glauber é o político, mas não qualquer político. Trata-se de um político com ambições intelectuais. E mais: é aquele que, sem preparo e honestidade intelectual, almeja ser escritor. Neste retrato, seu texto parte para uma estratégia narrativa que pode ser decomposta em dois movimentos: o de definição do tipo de personagem a que pertence Lacerda e o de ataque deste personagem, destituindo-o de

\footnotetext{
${ }^{88}$ Glauber Rocha, "Contra direitas e esquerdas o nosso cinema segue em frente", Última Hora, Rio de Janeiro (RJ), 27 fev. 1970, s/p.
} 
suas supostas pretensões de escritor. Pois para Glauber se há um paroxismo na relação entre arte e política - “Todo político quer ser artista. Todo artista quer ser político. Todo artista é mau político. Todo político é mau artista” -, o personagem por ele tratado não é uma coisa, nem outra: "Lacerda é a paródia do paroxismo: mau político, mau artista"89.

Voltando à definição do tipo de personagem, vejamos a coordenação de ideias adotada neste primeiro movimento narrativo. A definição do perfil do político Lacerda surge vinculada ao relato de uma discussão com outro personagem, Gabriel Garcia Marquez, figura tida pelo cineasta baiano como o especialista sobre ditadores latino-americanos e que, na ocasião, segundo o escrito de Glauber, escrevia a incrível história do ditador que vive 275 anos. Desta mesma idealização de um ditador é que surge a primeira premissa de definição lógica do que é um personagem político ditador - misto de facínora e malevolente, por excelência o representante do espírito conservador do status quo no mundo de condições subdesenvolvidas:

"Um dia o ditador acorda e diz que os papagaios estão conspirando contra ele. Manda matar todos os papagaios do país.

Um dia o ditador vai pelo corredor do Palácio. Aparece um rebelde que lhe aponta um revólver. O ditador manda o rebelde atirar. O rebelde fica com medo. O ditador chama os sicários e manda picar o rebelde. Depois corre até o banheiro. Muda as calças, limpa o suor e volta a desfilar. etc. etc..." ${ }^{\prime 90}$.

Se a primeira premissa é um alerta do poder sem compaixão presente nos traços do ditador, a segunda argumentação desponta a partir de sua derivação: relaciona-se com outro tipo de figura, que é definida pelo aspecto comparativo deste tipo sanguinário de poder. Trata-se do ditador frustrado; para Glauber um "tipo de gente pior que um ditador". Por silogismo, toda a descrição do ditador acima pode ser conduzida, com mais algumas pitadas sadomasoquistas, a este novo tipo de personagem criado pelo diretor de Terra em Transe. Faltava acrescentar ao composto lógico a personagem motivo do escrito, Lacerda. Então, é lançada mais uma terceira proposição: "Lacerda dá raiva porque é daninho. É

\footnotetext{
${ }^{89}$ Glauber Rocha, "O barato do Lacerda (não ficção, interartigo, duplifarsa,óleo de rícino, ensaitixix, etc.)", $O$ Pasquim, Rio de Janeiro (RJ), 05-11 mar. 1970.

${ }^{90}$ Glauber Rocha, "O barato do Lacerda (não ficção, interartigo, duplifarsa,óleo de rícino, ensaitixix, etc.)", $O$ Pasquim, Rio de Janeiro (RJ), 05-11 mar. 1970.
} 
daninho porque é um ditador frustrado, bê-a-bá"91. Mais uma vez por uma forma de argumentação silogística, a conclusão é que o conservadorismo e a malevolência do ditador do terceiro mundo a Lacerda se aplicam. E mais: com todas as tintas do exagero, pois afinal era de um perfil frustrado, como fazia questão de sublinhar.

Já definido o perfil de Lacerda e o seu rol de características políticas, o segundo movimento narrativo do texto é de um ataque mais contundente, sem as mediações da lógica silogística. O ataque está concentrado nas tentativas de inserção intelectual de Lacerda. É evidente o caráter sarcástico presente no conjunto de frases escolhidas, como pode ser visto no trecho abaixo:

"Como autor de teatro, que o diga Paulo Francis.

Como pintor chegou ao cúmulo de escrever besteiras como o azul pulula, o vermelho tirila, o amarelo fafala etc...

Fez críticas de música. Incursionou no conto, no ensaio filosófico, na botânica. Resultado: com meio século de vida não formulou nada de novo ou de velho" ${ }^{\text {"92 }}$.

O ponto-chave de entendimento do discurso sarcástico presente nesta segunda parte do artigo está no seu caráter de desestabilização dos motivos intelectuais de Lacerda. Lacerda é o autor de teatro que não é reconhecido pelo crítico teatral; é o pintor sem qualificação artística que escreve interpretações infantis; é o escritor que metralha para todos os lados, sem de fato assumir uma tradição ou sem arranhar a vanguarda. Glauber escolhe Lacerda como personagem de ataque, pois, por ele, pode fazer os acertos necessários e possíveis - em uma só vez, num mesmo instante - com a elite conservadora que lhe intrigava e lhe perseguia no momento. O que é Lacerda senão uma espécie de intelectual fora do lugar, representante legítimo de uma classe dominante e avesso ao pensamento radical. Antonio Candido vai dizer que, quando muito, na necessidade inevitável da mudança, a classe dominante apenas faz as concessões mínimas, não alterando em quase nada a situação estrutural da sociedade ${ }^{93}$. No limite do possível, diga-se bem, o ataque de Glauber deflagra

\footnotetext{
${ }^{91}$ Glauber Rocha, "O barato do Lacerda (não ficção, interartigo, duplifarsa, óleo de rícino, ensaitixix, etc.)", $O$ Pasquim, Rio de Janeiro (RJ), 05-11 mar. 1970.

${ }^{92}$ Glauber Rocha, "O barato do Lacerda (não ficção, interartigo, duplifarsa, óleo de rícino, ensaitixix, etc.)", $O$ Pasquim, Rio de Janeiro (RJ), 05-11 mar. 1970.

${ }^{93}$ Antonio Candido, "Radicalismos", em Vários escritos, 2004, p. 197.
} 
esta falsa concessão presente na política nacional, colocando o dedo na ferida, sobretudo, de uma classe intelectual desestruturada com os rumos políticos do país.

Em certo momento do artigo, Glauber escreve o seguinte: "Ditador frustrado, artista frustrado, Lacerda entrou no barato: virou crítico de cinema e pra mim não tem

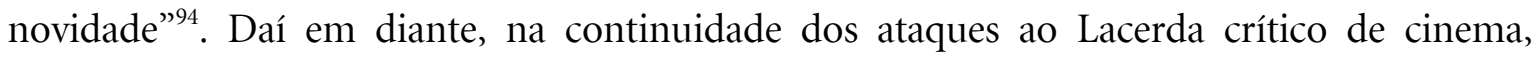
Glauber compõe habilmente um modo de criticar não só o seu personagem de foco, mas todo um modo conservador que ainda se opõe ao programa do Cinema Novo. Sua estratégia está em colocar Lacerda como o protótipo do crítico oponente às inovações modernas. Se não é moderno, o crítico de cinema Lacerda é a própria alegoria destes oponentes conservadores, por isso Glauber o identifica como "político atrasado. Lacerda chegou tarde”. E mais: “O [barato] do Lacerda é furado: ele usa termos como 'pancada' e isto não cai bem pra quem quer estar na onda. Os assessores de Lacerda, que lhe deram informações falsas sobre cinema brasileiro, deveriam atualizar também seus artigos" $\$ 5$. Certamente, o barato de Glauber foi tirar o barato do Lacerda, espécie de ironia que o texto incorpora ao seu conjunto.

Tal texto não é caso único no periódico alternativo. Muitos outros textos de Glauber n'O Pasquim seguem a via da ironia afinada aos seus objetivos políticos e estéticos. É caso do artigo "Tese: cada povo escolhe e vomita sua imagem apresentada no Beco da Fome, ponto de encontro do cinema nacional", de 30 de setembro de 1970. Neste pequeno texto Glauber vai elaborar a tese-irônica de que o Cinema Novo morreu. Nega-o para reafirmar sua força de movimento artístico duradouro e de intervenção social. Seu trabalho textual, em linguagem de manifesto "leve", está em se juntar aos que negavam o programa cinemanovista e sua agenda, para nesta negação afirmar o que acreditava ser o único caminho de resistência cultural.

\section{"Versão Brazaville"}

Se Glauber instalou o tribunal que julgou a figura de Lacerda, outras formas de combate permeiam este seu radicalismo nas contribuições ao periódico alternativo. Sempre

\footnotetext{
${ }^{94}$ Glauber Rocha, "O barato do Lacerda (não ficção, interartigo, duplifarsa,óleo de rícino, ensaitixix, etc.)", $O$ Pasquim, Rio de Janeiro (RJ), 05-11 mar. 1970.

${ }^{95}$ Glauber Rocha, "O barato do Lacerda (não ficção, interartigo, duplifarsa,óleo de rícino, ensaitixix, etc.)", $O$ Pasquim, Rio de Janeiro (RJ), 05-11 mar. 1970.
} 
ao seu modo, Glauber está disposto a configurar um cânone compatível com seu ideário estético e político.

Chamo a atenção para um texto "Os mortos do primavera" publicado n' $O$ Pasquim, de 29 de fevereiro de 1972, ano, por sinal, das suas vivências em terras cubanas. Mais próximo ao manifesto do que à análise racionalista e política das tensões vividas no campo intelectual nos anos 1970, sua crítica apresenta algumas nuances que podem ser relacionadas às suas próprias formulações estéticas anteriores. Como ponto de partida, vejamos os primeiros parágrafos em que apresenta um ritual africano de Zumbi:

"Versão Brazaville, o mito de Zumbi reaparece de lança e metralhadora num ritual de morte em Bakongo e faz um discurso materialista resumindo a história do negro sobre a terra, escravizado pra trabalhos agrícolas e domésticos nas Américas:

Nego safado

Nego bacana

Nego servil

Nego sacana

Ninguém melhor que Zumbi - projetado pela mágica e destruído pelas armas elimina as sutilezas da vanguarda intelectual capitalista euramericana:

Contra o fogo a fogo" ${ }^{\text {" }}$.

Longe de atender apenas à representação do mito, Glauber expõe uma versão do ritual mais próxima ao cenário de lutas, tanto políticas como estéticas, do terceiro mundo. Sua versão reapresenta o guerreiro como poeta, espécie de síntese entre as entidades de culto e a resistência de luta contra o domínio econômico e cultural dos brancos. Nos versos do guerreiro-poeta bradam-se, simultaneamente, a luta secular anticolonial e o teor místicoreligioso africano identificado também à realidade cultural brasileira. O que só leva a crer que Glauber ainda é atraído, entre outras coisas, pelas referências de Frantz Fanon, de Os condenados da terra, uma leitura constante desde os meados dos anos 1960.

Cabe aqui, como parênteses, o apontamento para dois de seus textos - um manifesto e um filme de exílio -, pois ambos parecem partilhar das mesmas motivações presentes neste texto d'O Pasquim. Comecemos pelo manifesto.

\footnotetext{
${ }^{96}$ Glauber Rocha, "Os mortos do primavera", O Pasquim, Rio de Janeiro (RJ), 29 fev. 1972.
} 
O manifesto Eztetyka do sonho, de 1971, apresentado numa conferência na Universidade de Columbia $^{97}$, tem um caráter de radicalização dos elementos presentes no seu manifesto mais famoso, "Uma estética da fome". A começar pelo seu ponto de ruptura, Glauber não mais tem uma medida de compreensão racional da pobreza, está voltado para o que denominou de irracionalismo liberador. Apenas por esta pulsão é que seria possível desviar-se da razão opressora, identificada ao racionalismo colonizador. Dar respostas em termos de razão revolucionária, segundo ele, não mais seria possível. Nesta sua nova formulação, ele escreve que "a revolução é a anti-razão que comunica as tensões e rebeliões do mais irracional de todos os fenômenos que é a pobreza”. Ligava-se, assim, antirrazão como revolução e razão burguesa como opressão. Nesse horizonte, só seria possível entender como forças desenvolvidas do continente latino-americano as raízes índias e negras, cabendo à classe média e à burguesia as "caricaturas decadentes das sociedades colonizadoras".

Por fim, para fechar estes longos parênteses, um comentário sobre o filme Der Leone has Sept Cabeças (O Leão de Sete Cabeças, 1970), mais especificamente sobre um de seus personagens, o Zumbi. Filmado no Congo, este filme é um ensaio glauberiano sobre as lutas coloniais na África. Glauber Rocha dilacera o mito original de Zumbi para transformálo em liderança de unificação do continente tomado pelos colonizadores e exploradores. $\mathrm{O}$ Zumbi de $O$ Leão assumirá a perspectiva histórica de análise, o que o aproxima ao Zumbi personagem do texto crítico d'O Pasquim. A situação fica mais evidente numa das primeiras falas de Zumbi; com o olhar direto ao espectador - no que seria a quebra de protocolo na decupagem clássica -, a personagem assume o efeito de distanciamento brechtiano, descolando do mito enquanto fábula e fantasia e assumindo a dimensão revolucionária e política:

\section{"ZUMBI}

Há dois mil anos os leões e os leopardos corriam livres pela floresta.

Há dois mil anos os deuses viviam livres nos céus e nos mares. Há quinhentos anos vieram os brancos que, com suas armas de fogo, massacraram os leões e leopardos, com suas armas de fogo incendiaram o céu e a terra dos nossos deuses. Os brancos levaram nossos reis e nosso povo para trabalhar como escravos nas novas terras da América. Nossos deuses partiram com nossos reis e nosso povo. Nas novas terras da América nossos deuses assistiram aos sofrimentos de nossos

\footnotetext{
${ }^{97}$ Cf. Glauber Rocha, Revolução do Cinema Novo, 2004, pp. 248-251.
} 
reis e de nosso povo. Os escravos negros trabalharam duro para enriquecer os patrões brancos, seu suor era de sangue, e esse sangue tornou frutíferas as plantações de tabaco, de algodão, de cana-de-açúcar e outras maravilhosas riquezas da América. Mas um dia os deuses se revoltaram e nosso povo pegou nas armas para reconquistar sua liberdade. Nosso povo e nossos deuses lutam há cerca de trezentos anos contra os brancos que não cessam de dizimá-los numa barbárie sem precedentes. Mas os brancos não vão conseguir me matar, eu, Zumbi, que reencarno os chefes assassinados. Minha lança há de rachar a terra em duas. De um lado hão de ficar os carrascos, de outro toda nossa África, livre. Aqui e em todo lugar, o menor dos negros levará em seu seio um pouco d’África. Agora enfrentaremos seus exércitos com as lanças e com a magia. Contra o fogo, o fogo".

Se não é possível afirmar com todas as letras que estes dois textos sumariamente, aqui levantados - sugerem a própria gênese do trabalho publicado n'O Pasquim, é possível vê-los em estreito diálogo. A questão do irracionalismo e a valorização das raízes africanas e indígenas como a única forma possível de enfrentamento da opressão do racionalismo colonizador presente no manifesto e o deslocamento do mito original para um ritual mais político com perspectiva histórica transparente e de ambição radical, em que Zumbi aparece como liderança revolucionária na integração africana, presente no filme, são pontos materializados nestes primeiros parágrafos de Os mortos do primavera. Portar lança e metralhadora é seu aspecto de luta política revolucionária. Ser projetado pela magia é seu aspecto de irracionalidade. Integrar a este guerreiro a matéria do poema é sublinhar a importância de dois termos: guerra e poesia. A luta estética está intimamente ligada às lutas de liberação dos povos colonizados. Eis o ponto de perseguição de Glauber. Não se pode esquecer que, à época, o cineasta está dimensionando e fazendo inúmeras tentativas de difundir seu programa de um intelectual tricontinental.

A abordagem de Zumbi apenas sinaliza os motivos de debate presentes neste texto de análise. Deve-se lembrar que Glauber assume a perspectiva do ataque e seu texto encara a dimensão do discurso de um manifesto. Como tal, vai abusar no fraseado agressivo, levantando teses que apontam a agonia do momento passado (pós-64 e pós-68) e o dilaceramento do sujeito no estágio de desenvolvimento do capitalismo de então, um modo do artista ainda sobreviver às exigências do exílio. Seus ataques passam pelos intelectuais dos países pobres, que, sem força política, pouco podem fazer diante dos mecanismos de ditaduras presentes por toda América Latina. Glauber enuncia a missão destes intelectuais: 
"escrevem e traduzem textos das civilizações dominantes e se estraçalham em intrigas" ele, o exemplo mais grotesco segue com o concretismo: "páginas de jornal gastas em difundir textos de poetas anglo-saxões, traduzidos e no original"99.

Está em jogo a distinção entre o tipo de intelectual e artista que pouco interage com o mundo ao seu redor e o tipo intelectual e artista que se afina à experiência social e dela sabe extrair o seu veio mais lírico, este seu modelo preferido. Nota-se que Glauber não está disposto a discutir apenas o temário da condição colonial. Sua crítica está em precisar os problemas de ordem formais. Preocupação que já pode ser constatada antes mesmo de suas colaborações n'O Pasquim. Se tomarmos o seu texto já aqui levantado, o Revisão Crítica do Cinema Brasileiro, tal constatação não deixa dúvida.

Em meio à dinâmica já de um capitalismo avançado dos anos 1970, a tonalidade de suas críticas ao modelo industrial - n'O Pasquim, de modo geral, e neste texto em específico - não poderia deixar de ser contundentes e explosivas. Não haveria outro modo de compor sua crítica social, a não ser pela linguagem de manifesto, talvez a única fagulha de contrapeso ao sistema massivo que já se estabilizava. Glauber no exílio já sente o peso das críticas, mas mesmo assim, diante das dificuldades, ele sempre está a trançar os fios de uma discussão contemporânea com as práticas ainda possíveis de resistência cultural. É seu empenho demarcar ainda os programas e a agenda possível da utopia revolucionária pelas vias da arte. Não deixa de ser natural também que o seu texto encare estes momentos de choques em que se imprime o rompimento entre o mundo ainda sem o domínio dos mecanismos da indústria cultural e o mundo já ambientado pelo conformismo próprio do capitalismo, carregando o próprio dilaceramento do sujeito moderno. Sua profissão de fé encarava o papel do artista (e, sobretudo, do cineasta) na discussão destes limites:

\footnotetext{
"A leitura materialista de nossa civilização nos últimos dez anos está em alguns filmes, canções, textos, conversas, peças, documentos. As teses cinematográficas são as mais radicais. Quase todo o resto é complacente, visa o mercado colonial, a programação e se consome na iconoclastia revisionista. A caretice desta fofoca facilita a penetração das comunicações de massa que absorvem os conformados a integração da arte na tecnologia" ${ }^{100}$.
}

\footnotetext{
${ }^{98}$ Glauber Rocha, “Os mortos do primavera”, O Pasquim, Rio de Janeiro (RJ), 29 fev. 1972.

${ }^{99}$ Glauber Rocha, "Os mortos do primavera”, O Pasquim, Rio de Janeiro (RJ), 29 fev. 1972.

${ }^{100}$ Glauber Rocha, “Os mortos do primavera”, O Pasquim, Rio de Janeiro (RJ), 29 fev. 1972.
} 
Suas conclusões finais são apontamentos mais duros, que trazem nas constatações a tensão da experiência daquele mundo, não mais das utopias dos anos 1960, mas na repressão da modernidade capitalista em rijo vigor, das dificuldades enfrentadas desde anos anteriores. Suas cartas de 1970 já são marcadas por estas novas tensões por ele vividas. Escrita no segundo semestre de 1970, a carta endereçada ao crítico de Positif, Michel Ciment, dá a dimensão dos problemas:

\begin{abstract}
"Perdemos todas as esperanças, a situação está fechada, o cinema novo acabou, somos vítimas das repressões, de um lado, e das intrigas entre os exilados em Paris. Os exilados acham indigno que eu ainda esteja livre, mas não sou culpado de estar livre. Nesse momento sou vítima de meu 'prestígio', sobretudo por causa de ti e de outros amigos, você entendeu? E as pessoas não me perdoam. Outro dia um amigo que está na cadeia me disse: neste país você vai pagar pelo resto da vida o preço de ter feito quatro filmes de sucesso antes dos 30 anos. Por isso, talvez, não quero mais fazer filmes de sucesso, estou completamente neurotizado por essa situação, entre uma direita fascista e uma esquerda fascista" ${ }^{101}$.
\end{abstract}

É para ele o fim dos ciclos e o início dos rituais privados humilhantes, numa constatação que o faz evocar o Drummond do poema $O$ medo. Evocava talvez as próprias dificuldades. As últimas linhas já demonstram este corpo a corpo com a vida, sobrando uma figura, talvez a mais cara à sua obra: a agonia. Afinal, "tudo é antigo. Ficou chato ser moderno. Meu olho ta pedindo arrego, meu ouvido, minha voz - chega de versos, sons, filmes e conversa fiada. É a precoce miséria de uma filosofia" ${ }^{102}$.

Resta lembrar que não é coincidência que um de seus personagens mais agudos, Paulo Martins, de Terra em Transe, cuja jornada termina com o sacrifício do herói, solitário nas dunas - sem Sara, sem o mundo da política -, já exibe as marcas da derrota no calor da hora e a agonia da experiência vivida de um tempo dos anos 1960. Uma agonia não só daquele tempo, mas que ainda nos coloca frente a frente com um personagem mais vivo do que nunca, tal qual Glauber Rocha. O exílio era a parte de sua consagração e foi parte de sua derrocada. Uma derrocada que o traria novamente para terras brasileiras. Isso só em 1976.

\footnotetext{
${ }^{101}$ Glauber Rocha, Cartas ao mundo, 1997, p. 372. [carta de 1970, sem local, endereçada por Glauber a Michel Ciment].

${ }^{102}$ Glauber Rocha, “Os mortos do primavera”, O Pasquim, Rio de Janeiro (RJ), 29 fev. 1972.
} 


\title{
IV. O ensaísmo de Glauber na volta ao Brasil
}

\begin{abstract}
Uma notícia que lhe parecerá talvez contraditória. Estou disposto a voltar ao Brasil mesmo que seja para enfrentar um processo. $O$ que poderão fazer além de me prender uns dias $e$ me dar umas porradas? Não quero continuar nesta ambígua situação de exílio, minha experiência foi rica durante esse tempo, mas tremendamente sofrida. Acabou o ciclo com esta última viagem. Não quero ir para a ÁSIA? VOLTO PARA CASA.

[...] Diga-me também na sua carta o que você acha. Se eu devo voltar ou não. Apesar de pedir a opinião eu dei a volta ao mundo e quero voltar. Pode ser um erro que me mate? Criou-se em torno de mim uma mitologia que me estrangula. Pobre, exilado, com raríssimos amigos, com uma relação sentimental forte mas crítica: por causa das miseráveis infra-estruturas, não vejo outra saída e não tenho. Então devo arriscar.

Glauber Rocha, em carta a Paulo Emílio [Paris, 26 jan. 1976]
\end{abstract}

\section{Um novo colunista na Folha de S. Paulo: abertura política e prática intelectual}

O exílio voluntário que Glauber Rocha inicia nos primeiros anos da década de 1970 é marcado pelo trânsito. Pelo trânsito de ideias, de projetos intelectuais, de endereços e domicílios, de companheiras e, sobretudo, de relações pessoais, muitas destas alimentadas em vigorosas cartas remetidas e recebidas. A pesquisadora e ensaísta Ivana Bentes, na "Introdução" à edição das cartas de Glauber, deu especial atenção para o caso. A metáfora criada por ela parece ser a que melhor se adéqua ao tratamento da questão: este período de exílio glauberiano é comparável a "um quebra-cabeças biográfico e geográfico", verdadeiro "périplo romanesco", resultante em "centenas de cartas, escritas de quartos de hotel, 
apartamentos provisórios dos amigos, produtores ou mulheres"1. O desespero da escrita compulsiva das cartas em ambientes carregados de instabilidade e transitividade, buscando-se reativar conversas, polêmicas e amizades de outrora, sem contar suas inúmeras tentativas de angariar fundos para a manutenção da vida no estrangeiro, é a imagem mais significativa de um mundo de dificuldades enfrentado por ele durante todo o exílio, entre 1971 e 1976. Não só explicita suas tentativas de formular uma vida estável na Europa, tal imagem é, por outro ângulo, uma marca precisa de seu envolvimento com as questões nacionais e com sua disposição sempre partidária com os modos de organização de um grupo de intervenção no campo cultural brasileiro de então. Em meio à intempérie da vida, neste sentido, parece emblemática sua frase dirigida a um de seus principais interlocutores de momento, Cacá Diegues: "Mas é no fogo da luta que se faz a melhor teoria da prática”"

Se tal mobilidade que o acompanha nesta sua dura e longa jornada no exílio tenha incidido sobre o mundo de sua correspondência no período, talvez não seja nenhum exagero também supor desdobramentos em outros ramos intelectuais de sua vida de homem de ideias e de letras. O saldo no exílio não é dos melhores, apesar de o cineasta trazer a público cinco novos longas-metragens, entre novas produções e finalizações de projetos mais antigos. Glauber sente o gosto amargo das críticas europeias e a necessidade de sobreviver às migalhas. Não está mais diante da unanimidade que imaginava ter. Não vê outra possibilidade a não ser voltar ao Brasil.

A volta ao Brasil é a precipitação final de como tudo gravitou ao seu redor nestes anos de estrangeiro. É preciso voltar nestes anos e acompanhar mais de perto certas ações de Glauber. Só assim se compreenderá suas formulações, ilusões criadas e demais incertezas, todas estas configuradas entre o limite da vivência no exílio e a necessidade de instituir intervenções políticas em torno do seu velho grupo de Cinema Novo, que ainda acreditava dominar e liderar.

O salto é para 1972. Em carta escrita de Cuba, Glauber comunica a Cacá Diegues, amigo de longa data, a necessidade de voltarem a se fortalecer como grupo. Para tanto, a estratégia mais apropriada passaria pelo ataque aos novos grupos formados, aqueles que porventura não notassem a relevância do Cinema Novo como força política no campo

\footnotetext{
${ }^{1}$ Ivana Bentes, “Introdução”, em Glauber Rocha, Cartas ao mundo, 1997, p. 41.

${ }^{2}$ Glauber Rocha, Cartas ao mundo, 1997, p. 455. [carta de jun. 1973, Paris (França), endereçada por Glauber a Cacá Diegues].
} 
cultural. A enumeração de ataques é grande e a produtora Belair Filmes, de Rogério Sganzerla e Julio Bressane, mais os trabalhos de Oiticica, entre outros, são os escolhidos para o ataque:

"chegou a hora de pulverizar os ratos. pau neles com Detefon. vocês estiveram muito frouxos durante anos. você e Gustavo, em dobradinha, são os melhores do país. esculhambar o livro de Flávio Moreira da Costa, trabalho pra Calmon. dizer pra Oiticica que ele chegou tarde com a favela no museu porque Nelson com Rio Norte 40 graus já tinha mostrado a favela ao mundo e achado uma merda. Oiticica dever ser acusado de explorador sexual de favelados. denunciar a Bel Air como uma empresa diletante que sabotou a luta pelo mercado vendendo filmes a Severiano Ribeiro. análise econômica da produção. Análise do material filmado: plano Helena Ignez dançando com punhal no jardim, onde te vi Odete Lara de punhal e vestido violeta? fácil exterminar canalha.

e dizer que Sganzerla é moleque de boca mesquinha porque se fosse cafajeste mesmo e se tivesse coragem contaria no Pasquim que selecionou as más críticas de Terra em transe em Cannes pro Estadão, colaborando com Dr. Romero Lago”’ ${ }^{3}$

Nesta carta remetida à Cacá e aberta aos demais cinema-novistas, Glauber traça um claro objetivo. Quer retomar as discussões coletivas e partir para a proposta de criação coletiva entre os seus pares. A cada um dos autores ele não hesitou em formular novos projetos de filmagens e ações a serem executadas, lembrando os velhos tempos. No exílio, tomado pelas saudades dos amigos, coisa que sempre deixava transparecer em todas suas cartas remetidas ao Brasil, o sentimento beira a volta ao tempo perdido: "vamos parar de elogiar filmes imperialistas e retomar o vigor de 62 ".

Ainda em 1972, mas já em Paris, Glauber anuncia aos mais próximos as dificuldades materiais de sobrevivência no exílio, mais um fator que o perturbava na vida longe do Brasil e na Europa. Em outra carta ao mesmo Cacá Diegues, ele esclarece que "muita coisa se virou contra mim mas não curto esta de mártir - hoje estou vendo como me sacrifiquei e me acho ridiculamente reduzido a um pária em Paris e todos fogem de mim como se eu fosse o perigo, a doença, o pecado" 5 .

\footnotetext{
${ }^{3}$ Glauber Rocha, Cartas ao mundo, 1997, pp. 434-435. [carta de 1972, Havana (Cuba), endereçada por Glauber a Cacá Diegues].

${ }^{4}$ Glauber Rocha, Cartas ao mundo, 1997, p. 437. [carta de 1972, Havana (Cuba), endereçada por Glauber a Cacá Diegues].

${ }^{5}$ Glauber Rocha, Cartas ao mundo, 1997, p. 446. [carta de 5 jul. 1972, Paris (França), endereçada por Glauber a Cacá Diegues].
} 
O ano de 1973 se inicia e as coisas não parecem melhorar para seu lado. Mais tarde, em carta de agosto de 1974, confessaria ao amigo Paulo Emílio que aquele havia sido o ano de "luta contra a fome". A Zelito Viana, havia dito, no início de 1974, que sua sobrevivência, naqueles recentes anos de exílio, tinha sido "com 37 mil dólares faturados a leves penas nesses três anos incluindo também os trocados de Claude [-Antoine] - os tais

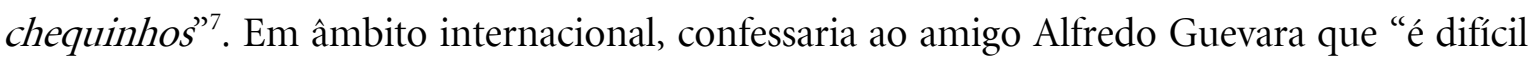
estudar e produzir sem dinheiro"8. As tentativas de sobrevivência chegavam aos ouvidos do Estado brasileiro. Em correspondência com a Embrafilme, representada na figura de Marco Aurélio Marcondes, um dos responsáveis na época pela distribuição de filmes nacionais em circuito, Glauber se mostra em necessidades prementes de conseguir alguns cobres, pague-se o que pagar: oferece direitos irrestritos de seus filmes em troca de adiantamentos pecuniários, numa tentativa de fazer com que o Estado lhe encampasse recursos para que assim pudesse continuar sua sobrevivência intelectual no exílio?.

No campo político, para se compreender a fatídica e famosa carta remetida a Zuenir Ventura, cuja publicação se deu na revista Visão, de 11 de março de 1974, sob o título “Abaixo a mistificação", e cujo teor, muito criticado pela esquerda nacional da época, vinha no sentido de apoio ao governo militar de Ernesto Geisel, afirmando que "os militares são legítimos representantes do povo" ${ }^{10}$, é preciso retomar uma discussão anterior entre Glauber e o seu amigo João Carlos Rodrigues.

De Roma, em 31 de agosto de 1973, o cineasta baiano, talvez motivado pelas recentes conversas que tivera com Jango e Darcy Ribeiro, faz uma minuciosa análise das movimentações políticas da saída de um presidente militar e a entrada de outro. Em via interpretativa, que se poderia no mínimo dizer bastante polêmica, ele encara a fração de militares - aquela representada por generais tais como Albuquerque Lima, Golbery Couto e Silva e Euler Ventes Monteiro - como portadora de uma visão nacional capaz de colocar em prática as transformações radicais na vida social que sua posição política, a de Glauber, tanto

\footnotetext{
${ }^{6}$ Glauber Rocha, Cartas ao mundo, 1997, p. 496. [carta de ago. 1974, Roma (Itália), endereçada por Glauber a Paulo Emílio].

${ }^{7}$ Glauber Rocha, Cartas ao mundo, 1997, p. 476. [carta de 6 jan. 1974, Roma (Itália), endereçada por Glauber a Zelito Viana].

${ }^{8}$ Glauber Rocha, Cartas ao mundo, 1997, p. 467. [carta de set. 1973, Roma (Itália), endereçada por Glauber a Alfredo Guevara].

${ }^{9}$ Cf. Glauber Rocha, Cartas ao mundo, 1997, pp. 469-471. [carta de 13 nov. 1973, endereçada por Glauber a Marco Aurélio Marcondes].

${ }^{10}$ Glauber Rocha, "Abaixo a mistificação", Visão, São Paulo (SP), 11 mar. 1974, p. 153.
} 
almejava. Embora talvez o crítico tenha cometido, em termos de estratégia, um de seus grandes erros assumindo tal posição de defesa - um ônus com a esquerda nacional que, sem exageros, se alongaria por todo o resto de sua vida - é preciso entender que nela, em tal polêmica, está suplantado o seu desejo radical de mudanças estruturais do país. Quando se olha em retrospecto, é evidente que, tempos depois, tal aposta se mostraria um verdadeiro infortúnio, pois com ela se trazia, a solavancos, também um preço alto demais a se pagar, o preço da própria repressão militar - fator desconsiderado por Glauber.

Mais que uma crença, a aposta nos militares no fundo traz consigo duas descrenças suas: na movimentação da esquerda brasileira de atuação interna no país e nas movimentações de forças culturais aqui em ação, caso do cinema underground da Belair Filmes, que notadamente ele denominava "udigrudi". Ao passo que a "união das vanguardas militares" é sumarizada por Glauber da seguinte forma: "Lamarca é a síntese dialética desta contradição fundada no inconsciente rebelde desde o alferes enforcado até a tenentada de 30 novamente significada no radicalismo do General Euler e do visionário Albuquerque que, sacando o óbvio, sabe que libertando o Brasil liberta o terceiro mundo"11.

Embora o próprio Glauber confie seus pensamentos a um fio contraditório de existência - lembre-se que meses antes o cineasta a este mesmo interlocutor, João Carlos Rodrigues, havia recomendado que este concentrasse "suas energias para destruir a ditadura militar" ${ }^{12}$-, deve-se buscar a compreensão de seu ponto de vista, neste biênio 1973-1974, sem todavia esquecer o horizonte de representações que a si próprio ele delegava como artista em ação política. Dizendo-se ser detentor do espírito revolucionário, ele demonstrava que seu horizonte de desejos de transformações estruturais também era passível, entre outras coisas, de incorporar esta tal participação da "vanguarda militar" em direção, como frisou, à superação da situação dependente de terceiro mundo.

A sua posição política se misturava ao próprio papel que ele afirmava ser da arte promovida por todos os cinema-novistas. Mesmo que mal sucedida, já que não conseguiram publicar na época, é modelar, neste sentido, a tentativa de se refazer um caminho de ação para o grupo por intermédio de uma nova fundação dos valores estéticos e políticos do

\footnotetext{
${ }^{11}$ Glauber Rocha, Cartas ao mundo, 1997, p. 462. [carta de 31 ago. 1973, Roma (Itália), endereçada por Glauber a João Carlos Rodrigues].

${ }^{12}$ Glauber Rocha, Cartas ao mundo, 1997, p. 451. [carta de 18 jan. 1973, Roma (Itália), endereçada por Glauber a João Carlos Rodrigues].
} 
movimento por meio do manifesto "Luz \& Ação: de 1963 a 1973"13, uma co-autoria com Carlos Diegues, Joaquim Pedro de Andrade, Leon Hirszman, Miguel Faria Jr., Nelson Pereira dos Santos e Walter Lima Jr. Voltando à carta remetida a João Carlos Rodrigues, parece bastante esclarecedora sua reflexão sobre esta ligação entre as possibilidades de transformações e o real papel do artista presente em seu discurso:

“[...] não é elitismo mas no terceiro mundo as vanguardas são as únicas que podem abrir as compressas pra massa mandar ver. sobre isto ler Isaac Deutscher. não mistifico povo pobre, doente, analfabeto e alienado, mas ao mesmo tempo temos que saber que somente a massa em ação muda a estrutura social. a falência do socialismo na Europa não significa o fracasso do materialismo histórico e dialético, que é uma ciência social, a única que explica o óbvio pelo capital, fetiche desta pobre e velha terra. não sou de utopias. ilhas ripis com escravos nos trópicos. no capitalismo, não sou do fenômeno, minha transa é com o objeto, a energia: LUZ X AÇÃO, e seremos felizes numa sociedade sem estados e sem classe. até chegar lá temos de seguir os caminhos inspirados em Lenin, Mao e os da pesada. os údigrudi são os radicais pequeno-burgueses histéricos que saíram por fumo enquanto seus símiles pra bala. caíram pelas esquinas mas, como diz Mao, um maoísta que fracassa não é um verdadeiro maoísta. ou, como Lenin, a única lei científica da política é aquela que leva à tomada de poder" ${ }^{14}$.

O ano de 1975 pode ser considerado o ano de articulação da volta de Glauber ao Brasil. Quase como gastar as últimas balas da agulha, ele faz suas derradeiras tentativas de ainda obter fundos para seus audaciosos projetos de produções cinematográficas no exterior. Recorre ao produtor francês Claude-Antoine, para o qual oferece a caríssima produção de $O$ nascimento dos deuses, beirando na ocasião as cifras de centenas de milhares de dólares. Tentativas em torno deste projeto e de outros o fazem percorrer os redutos europeus de Paris, Roma e da União Soviética; na América, percorre os Estados Unidos, além de oferecer o projeto no México, sem contar países da América do Sul; enfim, em sua jornada, ele chega à Ásia, em Bagdá. Tentativas, estas, malogradas.

Neste mesmo ano, Glauber filmou e finalizou seu último filme de exílio, Claro, este com recursos limitados: o sonho de levantar fundos milionários transformara-se em

\footnotetext{
${ }^{13}$ Cf. Glauber et al., "Luz \& Aç̃o: de 1963 a 1973", Arte em Revista, São Paulo (SP), jan.-mar. 1979, pp. 5-9.

${ }^{14}$ Glauber Rocha, Cartas ao mundo, 1997, p. 462. [carta de 31 ago. 1973, Roma (Itália), endereçada por Glauber a João Carlos Rodrigues].
} 
suaves 50 mil dólares para serem filmados em nove mil metros de filmes, nada mais. As circunstâncias encaminhavam-se como para uma saída que parecia ser inevitável - a volta do exílio. Como seria preciso preparar o terreno da chegada, restava a ele intensificar mais ainda seu contato com o universo nacional e com as pessoas que aqui estavam. Dentre as estratégias, nada melhor seria do que esquentar velhas polêmicas de âmbito interno. Refirome aos artigos "Glauber por Glauber", publicado no semanário Crítica, nos dias 1-7 de agosto de 1975, e "Vatapá no ventilador", estampado nas páginas do Pasquim, de outubro deste ano.

Se em Crítica, o lugar ainda era dos testes de repercussão das ideias, onde Glauber tinha a possibilidade de ver o veículo se transformar em tribuna para as novas atuações do grupo, ao passo de um de seus parceiros afirmar que este poderia ser o "veículo da reorganização das bases culturais, que começa a ocorrer” ${ }^{15}$, em contrapartida, o espaço do Pasquim já era uma realidade distinta e de ampla repercussão. Neste veículo alternativo carioca, Glauber tinha a seu favor o lugar privilegiado onde poderia assumir sua campanha de novos debates, traçando a movimentação e colocando em evidência, sob a chancela do velho movimento, antigos nomes dispersos em trabalhos individuais.

É o caso de descortinar o já anunciado "Vatapá no ventilador". Tal texto demarca um dos desejos do cineasta baiano, a volta aos velhos temas. O principal deles: a morte e vida do Cinema Novo, segundo ele, um movimento de "autênticos e moderados", tal como o Movimento Democrático Brasileiro (MDB). De um começo provocativo a uma parcela de críticos, em que escreve: "Se a imprensa brasileira se ocupa do CN [Cinema Novo], quer dizer que o movimento continua VIVO E NÃO MORTO como desde 1962 (pasmem!) declarou o Cientista Social Carlos Estevam nas páginas de 'Metropolitano'. Quer dizer: 13 anos de agonia! Um paciente que resiste a tantos atestados de óbitos e discursos fúnebres merece alta"16, seu salto vai direto para um acerto de contas com antigas desavenças, críticos de jornal que não haviam notado a importância de um de seus filmes mais consagrados, Terra em transe. Havia, para Glauber, uma contradição muito particular em toda a recepção crítica ao redor do filme, que o levava a afirmar que seu filme liberado pelos órgãos de censura, fora, por outro lado, censurado pelos críticos, os donos da opinião pública. Em seguida, novos

\footnotetext{
${ }^{15}$ Glauber Rocha, Cartas ao mundo, 1997, p. 552. [carta de 1975, Rio de Janeiro (RJ), endereçada por Orlando Senna a Glauber].

${ }^{16}$ Glauber Rocha, "Vatapá no ventilador", Pasquim, Rio de Janeiro (RJ), out. 1975, s/p.
} 
acertos de contas. Decorre o enfretamento com os opositores políticos, aqueles que ele supunha terem deturpado suas palavras lançadas no polêmico texto de Visão ("Abaixo a mistificação"). Dizia em voz altissonante: "Canalhas e medíocres cineastas, filhos espúrios do Cinema Novo! Quem mandou pra imprensa internacional xeroques de minhas declarações em Visão 74, com tradução TENDENCIOSA, e CORTADA, remontando AS FRASES QUE INTERESSAVA?" ${ }^{17}$.

Na nova discussão sobre os rumos do país, ele conseguia na brecha das ideias políticas fortalecer uma ideia bastante cara a sua figura: era um cineasta pobre, pois nunca estivera disposto ao mundo do cinema comercial ou da publicidade, contudo um cineasta político. Talvez fosse o caso de perguntar a quem se dirigia sua afirmativa: "Se vos dei beleza cinematográfica, posso vos dar beleza política" ${ }^{18}$.

A intensificação de notícias e entrevistas ${ }^{19}$ por ele enviadas estimulava antigos parceiros. Veja-se o caso de Paulo César Saraceni, que notou no gesto do amigo, diante da publicação do artigo em Crítica, uma simbólica tentativa de, em novo tempo, se reunirem para novas e imediatas respostas aos supostos opositores, numa chave de interpretação que parecia indicar que as exigências do passado ainda eram as mesmas. Tratava-se, como afirmou, de um sonho de um "novo novo". O tom da resposta de Saraceni é cheio de entusiasmo e mostrava o estímulo que o amigo conseguira pela sua mensagem política deixada nas páginas do jornal. Em outras palavras, Glauber havia obtido um primeiro êxito com o apoio de um fiel escudeiro, o mesmo dos velhos tempos, embora restasse ainda saber por quanto tempo mais:

\begin{abstract}
"Vibrei com tua nova aparição. E cheio de planos, filmes prontos e o mesmo transe de sempre. O depoimento bomba para Crítica veio pegar o pessoal desprevenido e eu no momento de uma luta idiota mas quente para conseguir tutu para o Anchieta. E fui o primeiro que tive que responder. Senti que apesar da paúra e do respeito do pessoal a tua bomba veio mexer em casa de moribundos e o pessoal chiou e eu fiquei gritando, que isso pessoal vocês não entenderam nada o
\end{abstract}

\footnotetext{
${ }^{17}$ Glauber Rocha, "Vatapá no ventilador", Pasquim, Rio de Janeiro (RJ), out. 1975, s/p.

${ }^{18}$ Glauber Rocha, "Vatapá no ventilador", Pasquim, Rio de Janeiro (RJ), out. 1975, s/p.

${ }^{19}$ Cf. Paulo Francis, "Glauber Rocha”, Status, São Paulo (SP), mar. 1975, pp. 13-17; Orlando Senna, "Glauber Rocha, cineasta desconhecido no Brasil”, Crítica, Rio de Janeiro (RJ), 31 mar. - 06 abr. 1975, pp. 12-13; M. Pontes, "As muitas mortes e ressurreições do Cinema Novo. Terra em Transe", Jornal do Brasil, Rio de Janeiro (RJ), 10 dez. 1975, p. 10; M. Pontes, "Deus e o Diabo no tempo do exílio (Glauber Rocha se explica, desabafa, faz história e até futurologia)”, Jornal do Brasil, Rio de Janeiro (RJ), 13 dez. 1975, p. 10.
} 
Glauber quer é sacudir, botar chuva e sol na roseira, o que está faltando é tesão e coragem e o baiano tá mandando seus fluídos de lá, vamos aproveitar o embalo e mandar ver" ${ }^{20}$.

Do outro lado, é bem possível que Glauber também estivesse estimulado com as notícias que chegavam de cá do Atlântico. Por certo, uma das novidades que mais possa ter lhe agradado, o ocupado de esperanças, era a fixação de homens de seu antigo grupo em torno da Embrafilme. Zelito Viana, em carta enviada entre maio e junho de 1975, informalhe certos passos da notícia: "A política cinematográfica ferve a 1500 graus. Nunca nos reunimos tanto. Os homens entregaram esta loucura que é o cinema brasileiro praticamente em nossas mãos. Grande responsa junto com uma grande perspectiva. Uma nova safra se anuncia, saída desta nova Difilm revista, madura e ampliada que está se tornando a Embrafilme [...] Geisel encampou a luta do mercado pessoalmente. O papo dele com o pessoal que foi lá - Luís Carlos, Nelson, Roberto [Farias] e Jece - foi do caralho. Falou inclusive em abertura da Censura" ${ }^{21}$. Em referência a esta mesma questão, a Cacá Diegues Glauber demonstrava seu otimismo: "A luta aí é correta nesta Embrafilme. Manter o poder na Embrafilme, mas evitar que se crie o monstro tecnocrático que vai reprimir as novas gerações. Está é minha última preocupação"22.

Ao final de 1975, é possível supor que Glauber já soubesse que ali estava se fechando seu tempo de exílio. O fim de um ciclo de experimentações longe da terra natal. A volta seria questão de meses, como se veria. Através das inúmeras experiências vivenciadas, o cineasta baiano chega em território brasileiro marcado profundamente pelos sucessos e insucessos lá fora obtidos.

Em suma, é possível supor que seu olhar havia se transformado e conectam-se a ele, sobretudo, dois pontos que considero centrais para o debate:

1) A desilusão de ter sido considerado um grande cineasta pela crítica europeia e tempos depois ter sido deslocado ao segundo plano de importância, com críticas, muitas delas ácidas em exagero, que dificultavam ainda mais seus planos de realizar produções

\footnotetext{
${ }^{20}$ Glauber Rocha, Cartas ao mundo, 1997, p. 528. [carta de set. 1975, Rio de Janeiro (RJ), endereçada por Paulo César Saraceni a Glauber].

${ }^{21}$ Glauber Rocha, Cartas ao mundo, 1997, p. 521. [carta de 1975, Rio de Janeiro (RJ), endereçada por Zelito Viana a Glauber].

${ }^{22}$ Glauber Rocha, Cartas ao mundo, 1997, p. 521. [carta de 22-23 ago. 1975, Paris (França), endereçada por Glauber a Cacá Diegues].
} 
custosas e ousadas para um estrangeiro na dinâmica do mercado europeu de bens culturais. Tal razão foi tão aguda na vida de Glauber que o levou a responder um dos seus críticos, Jean Louis Bory, do jornal francês Nouvel Observateur, em frase emblemática sobre sua condição: "Os críticos de Paris que proclamaram Rocha gênio vão massacrar Rocha. Muito típico, de profundo reacionarismo"23. Na mesma medida, é também possível supor que Glauber estivesse desalinhado e desiludido com os encaminhamentos da força política de esquerda na Europa ocidental. Suas cartas, de alguma forma, comunicam isso também, demonstrando aos seus interlocutores que a situação não era nada cômoda tanto do ponto de vista da inserção intelectual, como do ponto de vista do sustento material. Suas ideias já não repercutiam como antes;

2) Da desilusão do exílio à necessidade de ação. Na esperança de dias melhores, encontrou na volta ao Brasil um modo de se estabelecer como intelectual e cineasta. Aqui, em seus planos, Glauber poderia incluir, como de fato mais tarde aconteceu, o financiamento público para seus projetos. Mesmo longe e sucumbido pelas reais dificuldades, Glauber aposta na reorganização do movimento, no enfrentamento de críticos de âmbito local e na necessidade de demonstrações de seus sérios problemas financeiros, um "proletário intelectual desempregado", como chegou certa vez a afirmar.

É evidente que todo este sentimento, mistura de desencanto e necessidades prementes, tenha ganhado em Glauber um aspecto centralizador e fundador na configuração de uma atitude retórica ímpar, amparada em uma nova fase de seus escritos. Estes, cada vez mais modulados pela atividade política e pela leitura em retrospecto dos seus feitos culturais, demarcam mais uma vez o território para uma revisão crítica do passado e do seu presente, sempre ao modo de Glauber. Seus textos de colaborações na Folha de S. Paulo são verdadeiros campos de tensões impostos por tal retórica. É o que se segue.

\section{Abertura polytyka, abertura eztétyka}

Ao leitor de hoje, talvez cause certa estranheza um primeiro contato com os textos da coluna de Glauber Rocha, publicados, em geral, na página dois do caderno

\footnotetext{
${ }^{23}$ Glauber Rocha, Cartas ao mundo, 1997, p. 546. [carta de dez. 1975, Paris (França), endereçada por Glauber a Jean Louis Bory].
} 
Ilustrada, na Folha de S. Paulo, no ano de 1978. A causa da estranheza não se limita aos aspectos de conteúdo abordado, embora estes fossem muito polêmicos e provocativos. Ao lançar-se no papel, a língua afiada de Glauber segue o mesmo ritmo febril de seus vulcânicos pensamentos. Convivem, uma junto à outra, duas ações linguísticas, possíveis causas iniciais do referido estranhamento: uma radical liberdade sintática ritmada pela oralidade exacerbada, própria, esta, de sua intemperança retórica, e o uso de palavras com uma grafia distintiva e original, longe, em muito, da ortografia clássica do convencionalismo dos dicionários. Miséria transforma-se em "myzerya"; Brasil em "Brazyl”; político em "polytyko", e assim por diante. Lado a lado, caminham-se o seu balanço temático e o seu balanço formal.

Tal evidência solicita um questionamento: qual a razão da adoção desta nova forma ortográfica? O que ela significa para o intelectual em sua condição recente naquele momento de ex-exilado? O que isso sugere dentro de seu balanço de fatos e ideias do momento?

Em 1956, o pensador alemão Theodor Adorno publicou o texto "Sinais de pontuação", mais tarde reunido em seu célebre livro Notas de literatura I (1958). Como de praxe, o lance interpretativo de Adorno, carregado como sempre de um "estilo atonal" e de um ensaísmo fragmentário e ao mesmo tempo totalizador das ideias e conceitos, partiu para o inusitado. Sua especulação filosófica procurou desvendar, dentro das condições inerentes à própria escrita, o "status fisiognomônico" ${ }^{24}$ dos sinais de pontuação. É desse modo que o ensaísta alemão remeteu sua análise aos aspectos constituintes de linguagem presentes nos sinais gráficos de pontuação e ao caráter vivo e histórico destes. Adorno vinha demonstrar a relação conflitante entre os escritores e a forma e o uso dos sinais de pontuação. A escolha entre um travessão, um parêntese ou os pontos de reticências poderia, no fundo, revelar as opções da visão social e de mundo de um escritor. Ainda mais. Adorno demonstrava que se estes, os sinais, por certo eram inseparáveis da função sintática de um texto, nesta mesma função sintática eles, em contrapartida, não poderiam se esgotar.

Rica e envolvente, a matéria levantada pelo pensador alemão serve de estímulo para que se reflitam as entranhas tipográficas presentes no texto glauberiano, no sentido de apontar seu valor mais duradouro e suas implicações com a visada histórica ali presente. Proliferam-se nos textos articulados por Glauber para a Folha não só o uso dos travessões, dos pontos de exclamação, de interrogação, pontos-e-vírgulas, entre outros sinais, mas

\footnotetext{
${ }^{24}$ Theodor Adorno, "Sinais de pontuação", em Notas de literatura I, 2003, p. 141.
} 
também o uso das demarcações tipográficas representadas nas grafias de palavras em maiúsculas (padrão de caixa-alta no meio editorial) e nas substituições em muitas palavras do "s" por "z", do "i" por "y" e do "c" por "k".

Glauber imprime aos seus textos um estilo singular na montagem das ideias. Parte para um estilo de exposição que privilegia a disposição de ideias na forma de fragmentos, como se fossem pequenos e explosivos textos. Encadeados um atrás do outro, estes minúsculos textos, formam um conjunto que ganha tanto pela independência de ideias como pela capacidade de se misturarem num fio condutor único e presente no texto. Fica a demonstração nestes casos que sua busca por este estilo atesta uma hipótese central em seus trabalhos: a aliança e a conjugação em sua prática escrita com as tensões e os contrastes da experiência vivida, para, assim, extrair sua matéria mais vulcânica e mais polêmica da realidade.

Antes de mais nada, é preciso notar que tais elementos gráficos (sinais de pontuação e ortografia original) são responsáveis em parte significativa na composição deste estilo. Através deles se formula a cadência do fraseado e do fluxo constante de imagens trazidas pelo ensaísta baiano. Através deles se impelem o silêncio ou grito que nas páginas dos jornais transformam-se mais do que nunca uma voz de opinião pública. Através deles se atenuam elementos não proveitosos para sua argumentação ou evidencia aqueles que ele desejava apoiar ou mesmo através deles protestar. O que, convenhamos, já não é pouca coisa.

No que se refere ao seu estilo de montagem, o paralelo mais evidente na literatura brasileira é a poesia de Oswald de Andrade. Haroldo de Campos, em crítica ao livro Paubrasil (1925), foi muito feliz quando nota o novo conceito de livro que aquela poesia propunha: "Seus poemas dificilmente se prestam a uma seleção sob o critério da peça antológica. Funcionam como poemas em série. Como partes menores de um bloco maior: o livro" 25 .

Ultrapassando seu aspecto de organização sintática, portanto sua função gramatical, introjeta-se, nesta pontuação e nesta forma particular de grafia das palavras, a história compartilhada pelo e do seu próprio autor. Explico melhor. Não é incomum nos textos de Glauber que um travessão ganhe o estatuto de um traço de pensamento, que ultrapassa em longe o papel de pausa que introduz uma inserção parentética. Por uma forma autoritária da retórica glauberiana, uma exclamação pode tornar-se um elemento que

\footnotetext{
${ }^{25}$ Haroldo de Campos, "Uma poética da radicalidade”, em Oswald de Andrade, Pau-brasil, 2000, p. 35.
} 
estabelece a ligação a uma ordem externa, num gesto, também autoritário, em que o ensaísta consegue dar ênfase àquilo que só o encadeamento lógico de ideias poderia formalizar, embora sem a devida força no ato da escrita. É neste caso, por exemplo, guardadas aproximações e proporções devidas de época, que Glauber se aproximaria à retórica vibrante de um Euclides da Cunha. Refiro-me aos textos de jornal do autor d'Os Sertões, quando na cobertura jornalística de Canudos, ele, volta e meia, bradava suas palavras num retumbante "Viva a República!"26. Sem ficar atrás, Glauber anunciaria, quase um século depois, o seu "Que VIVA BRAZYL!"27. As reticências são outro exemplo de forma e uso da pontuação aplicados ao estilo. Elas estão presentes em seus vários textos de colunista. Mais do que consagrar uma atmosfera fictícia para demarcar o fraseado sob um sentido inacabado, as reticências são a marca gráfica que sugere chaveamento no fluxo de ideias e fragmentos trazidos à tona por aquela escrita febril e disparada de Glauber.

No fundo, o uso de todos esses sinais gráficos, aliando-os à montagem das ideias em fragmentos, reforça uma exigência do autor Glauber. Trata-se, até o limite do possível, da sua rejeição ao convencionalismo das regras gramaticais. Embora não só isso. Sua rejeição também está diretamente ligada à parcela de discursos produzidos no campo político e artístico. Volto a salientar que Glauber vai até o limite do possível, pois, como já havia notado Adorno em relação à elaboração e utilização da gramática no jogo literário, se ele, o escritor, "não pode confiar nas regras frequentemente rígidas e grosseiras" 28 , ele também não pode ignorá-las por completo, sob o risco de cair no ostracismo e ser vítima de si mesmo, da própria excentricidade. E desta dinâmica particular Glauber não estava blindado.

É o caso de se notar, mais de perto, a forma como ele organizou suas ideias em torno da abertura política do país naquele fim de década.

As colaborações na Ilustrada se iniciam em 3 de junho de 1978, com o artigo "Limite". Neste texto, Glauber comenta o antigo filme de Mário Peixoto, homônimo ao título do artigo. Já o primeiro texto dedicado ao tema da abertura política estaria na Folha depois de duas semanas de iniciada suas colaborações para a coluna. Seu título é "Goal de Figueredo" e sua data de publicação é 17 de junho de 1978. Como é possível supor, o enfoque é a possibilidade de redemocratização no país, cujo pano de fundo está centrado na discussão da

\footnotetext{
${ }^{26}$ Cf. Euclides da Cunha, Diário de uma expedição, 2001.

${ }^{27}$ Glauber Rocha, "Goal de Figueredo", Folha de S. Paulo, São Paulo (SP), 17 jun. 1978, p. 30.

${ }^{28}$ Theodor Adorno, "Sinais de pontuação", em Notas de literatura I, 2003, p. 148.
} 
sucessão presidencial no período. Ano que sairia Ernesto Geisel e entraria João Batista Figueiredo.

Os passos de Glauber seguem a mesma linha de declarações iniciadas desde sua chegada ao Brasil. Ele não via outra saída que não a polêmica. Resultava-se no ataque à fração de intelectuais, no ataque aos partidos políticos, não importando quais fossem, e no ataque aos encaminhamentos adotados por instituições que porventura ele discordasse ou que dele discordassem.

Inicia seu texto manifestando um de seus provocativos apoios: "Let it be - devo me declarar Figueiredyzt num tempo em que a intelectualidade nacyonal prima pelo liberaliyzmu sambyztyk e roquete - a turma”29. A provocação, todavia, não terminaria no apoio ao general Figueiredo, o candidato da situação. Em complemento à estratégica adotada, Glauber passa a rechaçar também intelectuais, aliás, muitos deles de esquerda. Diz ele:
“[...] nenhum intelectual brazylyero tem opinião política formada. Mesmo Paulo Francis em 'Kabeça de Papel'. O Gilberto Vasconcellos perguntou-me como eu, sendo Anti-Machadiano poderia gostar de 'Kabeça', que era Machadiano. Ora, não sou anti-Machado: tenho problemas inexplicáveis com o Roberto Scwarz, aliás pessoa de riso simpaticíssimo e fina sagesse - talvez por causa da suspeita que tenho de que Roberto é anti comunista freudiano-fiquei contra Machado"30.

Em relação aos rumos da próxima gestão presidencial, Glauber expõe suas preferências, embora insólitas para o momento. Seu candidato ao Ministério da Educação é Antonio Candido. Seu candidato ao Ministério da Cultura é Francisco de Almeida Salles. Seu espaço no jornal consolida-se como o espaço das suas provocações. Debochado, Glauber aproveita, mais uma vez, para reagir contra os intelectuais brasileiros que constantemente expunham em artigos sua excentricidade: "Se o General Figueredo vai fazer Revolução Agrária (onde pastará melhor a burrice dos intelectuais liberais pentagonyztas.. )"31.

O fragmento de ideias está em toda parte nestes seus textos de colunista. Mesmo que o elemento central seja a discussão dos rumos políticos da sucessão, é bastante comum que, no meio do texto, Glauber introduza uma forma de digressão de ideias, voltando-se, sem aviso prévio, para outro assunto. Seu corte é brusco. E o leitor mais desatento perde o recado

\footnotetext{
${ }^{29}$ Glauber Rocha, "Goal de Figueiredo", Folha de S. Paulo, São Paulo (SP), 17 jun. 1978, p. 30.

${ }^{30}$ Glauber Rocha, "Goal de Figueiredo", Folha de S. Paulo, São Paulo (SP), 17 jun. 1978, p. 30.

${ }^{31}$ Glauber Rocha, "Goal de Figueiredo", Folha de S. Paulo, São Paulo (SP), 17 jun. 1978, p. 30.
} 
glauberiano fora do eixo mais visível dos fatos. Da mesma forma, sua comunicação, seja neste ou em outros artigos da Folha, não é nada didática. E suas opções instauram uma nova forma de explorar a mítica popular e nacional registrada no mundo histórico por meio do artefato jornalístico. Com isso, é possível avalizar a seguinte ideia: talvez esteja nesse encontro (entre as tradições mais nacionais e a resposta às demandas para se explorar um novo meio) uma preocupação comum na feitura de seus filmes e de seus escritos. Presente nos debates promovidos por seus filmes e nos seus artigos de jornal, esta preocupação sugere que o seu estilo se movimente a partir deste jogo de tensões em diferentes polos. Sem avisar dos chaveamentos existentes, seu estilo se movimenta, num vai-e-vem, do geral, e com espírito totalizador nas análises, ao particular, e com análise mais detida no mundo interior de personagens e suas emoções.

Consciente do seu papel de cineasta e do que é o dispositivo tecnológico do cinema na ordem cultural do século XX, Glauber procurou, em praticamente todos os seus filmes, explorar o povo e suas expressões culturais, sem desconsiderar os riscos da empreitada. Assumi-los sem levar em conta as devidas contradições poderia significar um tiro no escuro. É certo que não queria pagar para ver. No jornal idêntico jogo também é construído. Glauber está a par de que o mundo jornalístico também obedece aos preceitos da indústria cultural. Por este motivo, há em seu texto certos desafios ligados à apresentação de momentos de rupturas, ora estéticas com o meio, ora políticas com os discursos de esquerda e de direita correntes. Há nestas suas digressões no artigo de jornal uma maneira de expor o mundo sujeito à opressão de classe, transpondo nas suas entrelinhas o desejo de mudança radical.

No já referido artigo escrito para a Folha, o trecho a seguir exemplifica bem a questão: "Kultura? Nação? Trybu? A Revolução começa Antropologykamente, criando o Estado Mãe de Oswaldandrade. Estado justo, carinhoso, educativo, liberatório,

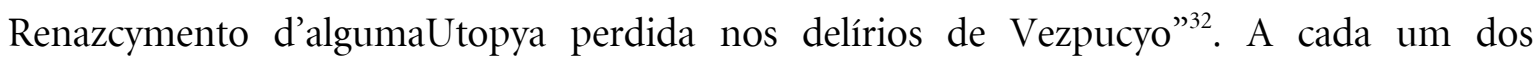
elementos de formação, acompanha-se uma pergunta. Das perguntas vem em estado bruto o novo Estado da nação. O que pensar disto? Glauber se apodera da cara metáfora uterina de Oswald para dar conta do nascimento da nova nação. A reflexão de Glauber sobre os elementos próprios da cultura nacional equaciona o índio. O mesmo indianismo oswaldiano,

\footnotetext{
${ }^{32}$ Glauber Rocha, "Goal de Figueiredo", Folha de S. Paulo, São Paulo (SP), 17 jun. 1978, p. 30.
} 
que, distante de ser formado pelo bom selvagem, este novo índio faz o enfrentamento contra a ardileza do colonizador e explorador das terras alheias.

Em 8 de julho de 1978, Glauber se dirige a mais um personagem da vida política brasileira. É Paulo Maluf e o seu artigo intitula-se “Fomaluf”. Embora não seja formalmente uma carta pública dirigida ao político paulista, o texto de Glauber, em seus aspectos de constituição narrativa, flerta com o específico gênero textual da carta. A todo o momento, Glauber evoca Maluf para uma conversa franca e aberta. Ao político, ele faz lembranças pontuais sobre o significado de governar o estado de São Paulo. Reitera a necessidade de o político firmar compromissos sociais: "São Paulo tem fome, Maluf, e você pode acabar com ela”33. E compromissos políticos a serem assumidos: “Assim, Maluf, governá São Paul equival a Governar o Brazyl, daí sua grande responsabilidade, Maluf, e sua obrigatória fidelidade a Figueredo" ${ }^{34}$. No flerte com o gênero da carta, Glauber instaura uma situação: dirige ao seu interlocutor (destinatário) uma série de questionamentos e perguntas como se, do lado de quem é o remetente, vinculasse o desejo vindo da expectativa de em breve receber uma resposta das interrogações lançadas.

$\mathrm{Na}$ mesma estratégia de evocar Maluf para a conversa, dando conta de certa ordem de problemas que o político precisaria enfrentar, Glauber expõe ainda sua expectativa maior: sobre políticos e a política brasileira no momento. Se o pano de fundo da discussão é o desafio que Maluf enfrentará, a abertura política não deixaria de ser evidenciada e mais uma vez o futuro presidente Figueiredo tornava-se um parâmetro comparativo para o mundo político nacional. Visto por Glauber como alguém faminto pelo poder, Maluf é distinto de Figueiredo. Embora o então futuro presidente, segundo imagem formulada pelo colunista, também estivesse faminto, sua fome tinha outra raiz: Figueiredo tem "fome de Justiça, ele não virou nenhuma mesa, ele recebeu ordens do Presydent Geisel pra cumprir a missão de acabar com a fome no Brazyl” ${ }^{\prime 3}$. Evocado sob a metáfora da grande feijoada ambientada em Macunaíma (o filme), de Joaquim Pedro de Andrade, quando o herói recupera o Muiraquitã do gigante Piaimã, Maluf é a espécie de herói sem nenhum caráter, cuja fome é deglutidora dos seus maiores inimigos: "Você, Maluf, me lembra Mário de Andrade, inclusive fisicamente. Sua vitória foi o Banquet de Venceslau Pietro Pietra em MACUNAYMA: Laudo

\footnotetext{
${ }^{33}$ Glauber Rocha, "Fomaluf”, Folha de S. Paulo, São Paulo (SP), 8 jul. 1978, p. 26.

${ }^{34}$ Glauber Rocha, "Fomaluf", Folha de S. Paulo, São Paulo (SP), 8 jul. 1978, p. 26.

${ }^{35}$ Glauber Rocha, "Fomaluf”, Folha de S. Paulo, São Paulo (SP), 8 jul. 1978, p. 26.
} 
era Wenscelau, você o jogou na Feyjoada"36. Glauber avança para colocar lado a lado mito e realidade. O colunista não apenas referencia no mundo dos fatos o lance estratégico criado por Maluf, quando da eleição para se o governo de São Paulo no ano de 1978, este desbanca na convenção da ARENA Laudo Natel, o candidato preferido do presidente Geisel, mas também coloca o peso de tal fato no circuito dos mitos. Nada parecia melhor do que trazer o registro mítico de Macunaíma à baila.

Essa mistura, em Glauber, entre suas posições políticas e o campo estético - este modalizado tanto na sintaxe formada por curtos períodos, sem muitas subordinações, como pelo uso de pontuação -, abre brecha para diferentes interpretações. Se sua escrita, alimentada por um fluxo febril de pensamento, vem à tona com grande agilidade de cortes e descontinuidades na mudança de assuntos e personagens levantados, tendo-se mesmo, em alguns momentos, a impressão de um ensaio de ideias através do delírio, é preciso também notar que o uso inovador de uma linguagem em jornal não invalida o viés conservador de uma posição política demarcada socialmente. Dito de outro modo, Glauber apresenta-se como um típico iconoclasta das posições políticas: nem esquerda, nem direita.

Quando ele demonstra, todavia, o apoio ao candidato presidenciável, sem que se faça notar uma chave de interpretação irônica dos fatos, Glauber deixa claro que Figueiredo possui um apoiador. Aos seus opositores, de imediato, Glauber faz lembrar a mesma polêmica inscrita antes em Visão, em 1974. Aos seus simpatizantes, talvez não apoiadores naquelas circunstâncias, Glauber sugere-lhes uma ponta de dúvida em relação aos seus próximos passos de intelectual. Enquanto sua aposta, naquele momento, até poderia ser na crença de que o perfil deste general levaria a uma inevitável abertura política, como de fato aconteceu longos anos depois, Glauber, por outro lado, trazia para si um pesado fardo para carregar. Afinal, apoiar militares no poder parecia, principalmente para a esquerda intelectual, uma falta de propósito sem tamanho. Só sugeria, mesmo que não pudesse ser, que o seu flerte com Estado denotava outras dimensões de suas relações com os militares.

No prosseguimento da exposição dos textos de Glauber publicados na Folha de $S$. Paulo, comento a seguir o sentido da relação que existe entre uso da forma do fragmento e a sua montagem no texto final. Para tanto, trago junto um exemplo privilegiado desses textos.

Que Glauber, naquele final de década, utilizava da exposição de fragmentos, nem sempre conectados entre si, para construir um todo organizado de ideias, fosse em sua escrita,

\footnotetext{
${ }^{36}$ Glauber Rocha, “Fomaluf”, Folha de S. Paulo, São Paulo (SP), 8 jul. 1978, p. 26.
} 
fosse na tessitura de um projeto de filme, isso não chega a ser nenhuma novidade. De mesma época, no plano fílmico, basta notar seu famoso curta-metragem, de 1977, sobre o artista Di Cavalcanti. Grosso modo, juntam-se em Di Cavalcantios fragmentos captados do velório do artista, fragmentos de matérias e poemas lidos pelo próprio autor, fragmentos das imagens de notícias do dia pós-morte do artista, das imagens do enterro, das imagens de obras do artista, a relação afetiva que o cineasta demonstra pelo seu biografado, entre outras coisas, para compor uma sinfonia cinematográfica em homenagem ao seu grande amigo pintor.

Urdido sob as mesmas bases, seus textos estabelecem relações duradouras entre o fragmento e o todo. E é nisto que entra uma componente central para a empreitada: o dado da montagem. Como um quebra-cabeça, o colunista vê em sua coluna o espaço propício para o ensaio através da montagem de ideias. Há casos em que isso é feito pelo uso do recurso do discurso direto. Parece-me emblemático, neste sentido, o seu texto "Folhynhaz da Prymavera”, publicado em 26 de agosto de 1978. Todo ele é formado por vários diálogos de vários personagens, incluindo o próprio autor, personagem de si mesmo. O ponto de vista para o assunto político fica mediado pela projeção, em tom jocoso, do que supõe ser a fala desses personagens.

Desde os anos 1960, ao escolher personagens históricos ${ }^{37}$, fossem eles contemporâneos ou não, ou ao criar personagens de caráter estritamente ficcional, e lhes oferecer certa voz, Glauber quase sempre opta por deixá-los, os dois tipos de personagens, carregados por demarcações políticas muito próprias, ligeiramente arredondadas por suas próprias perspectivas, a do cineasta e a do crítico. No caso de "Folhynhaz da Prymavera" isso se torna muito mais evidente. Porque tal arredondamento de ideias está sempre vigiado por Glauber como personagem de si mesmo no texto. Tal personagem está sempre a se intrometer na opinião alheia, com o objetivo de esclarecer as posições políticas próprias do autor e ensaísta. Em um dos casos, a personagem Heleninha lhe informa: "Existe uma campanha contra os concretistas". Em seguida ele, Glauber personagem interfere, esclarecendo, em tom de humor, a mea-culpa de uma situação do passado: "Nunca entendi porque concretistas, pois os considero geniais. Acho Haroldo de Campos devia ser Senador... Já imaginaram Haroldo Koncretyzando Reformaz?"38.

\footnotetext{
${ }^{37}$ Cf. Glauber Rocha, "Perseguição e assassinato de Glauber Rocha pelos intelectuais do hospício carioca, sob a direção de Salvyano Cavalcanti de Paiva" [peça teatral], Fairplay, Rio de Janeiro (RJ), 1967, pp. 10-16.

${ }^{38}$ Glauber Rocha, "Folhynhaz da Prymavera", Folha de S. Paulo, São Paulo (SP), 26 ago. 1978, p. 30.
} 
A dificuldade de detecção do ensaísmo praticado em textos com o perfil de "Folhynhaz da Prymavera" talvez se deva aos seus aspectos híbridos, em que componentes ficcionais dialogam em todo e em qualquer momento com o ensaio de ideias políticas, estas sempre sob o domínio das ações e práticas políticas de seu autor. É o caso, com o propósito de não confundir uma e outra coisa, de talvez apreender certos personagens submetidos ao texto glauberiano sob a perspectiva de comentadores de ideias. Como se sabe, tal dado, do uso da teoria brechtiana do distanciamento, não é novo para os estudiosos de Glauber e, em mais de uma vez, a referência foi notada na análise e interpretações de seus filmes.

Sobre o fato de Glauber procurar criar a perspectiva do comentador, abro neste momento parênteses. Nos primeiros acessos que tive aos materiais inéditos de Glauber, pude notar que o procedimento do uso de um comentador brechtiano também revelava-se em mais de um de seus textos. Foi quando resolvi testar esta hipótese em um de seus inéditos de arquivo. Desse modo, escolhi uma peça teatral, já brevemente comentada sob outros aspectos no capítulo II deste trabalho. Intitulada Jango (tragedya em 3 atos), a peça com um enredo, de fim trágico, retrata um personagem histórico da política nacional, o ex-presidente João Goulart, deposto pela ditadura militar, em 1964. Ao final, num ritual antropofágico, Jango é devorado pelo próprio povo. Segundo marcações do próprio autor, o drama fora escrito em 1976 e sua estrutura se divide em um prólogo e mais três atos. Como forma de exemplificar o uso do recurso do comentador por um dos personagens, interessa aqui apenas apontar dentro do terceiro ato, sua primeira cena, ambientada na fazenda de Jango no Rio Grande do Sul, no ano 1977. Em tal cena, estão os personagens Jango, de um lado, e Ezequiel, um operário, e Maria, a empregada doméstica da fazenda, de outro. Num primeiro momento, Ezequiel se mostra insistente com Jango. Solicita sua volta à vida política. Posteriormente, novos personagens entram em cena: Julio, um ex-guerrilheiro, Marina, uma jovem brasileira, e o negro americano Tony Spencer, um brasilianista de Harvard. Estes três demonstram que o propósito da visita havia sido uma entrevista com Jango. Reticente, num primeiro momento, com a figura do brasilianista norte-americano, o protagonista resiste a falar de si mesmo. O que não demora muito. Pois Jango inicia sua análise e o seu balanço aos fatos do passado.

O final da cena é, todavia, assumida por Ezequiel, que expõe sua condição de classe diferente daquela dos demais presentes. Ezequiel, neste final de cena, assume o lugar de comentador, trazendo à tona o incômodo olhar crítico, por assim dizer, ao leitor / espectador 
do drama. Sua voz reflexiva das suas condições de classe vem à tona ao passo que é estimulado pelo personagem central do drama, Jango. O protagonista, Jango, pede a Ezequiel que este fique. Afirmava que ainda possuía muitas outras histórias a contar ao operário, que de imediato lhe oferece uma resposta: "É tudo história dos donos do poder... sou um operário, doutor Jango, minha estória não tem nada a ver com a do senhor...”. Em outra situação de provocação, a personagem Maria, a empregada doméstica e legítima representante do povo lhe pergunta: “Como não, Ezequiel?”. A resposta do operário é arrebatadora, e comentadora tanto da alienação presente no discurso da personagem que o havia interrogado como das condições de classes menos abastadas: "Sou pobre, dona Maria... Doutor Jango está exilado, mas é rico, é o ex-Presidente, amanhã pode voltar e eu...fui preso, torturado, tinha família grande quer dizer, nem mesmo uma revolução muda minha vida, está ficando tarde, já que tenho quase cinqüenta anos, sou um animal sem esperança...”39.

Fechados os parênteses sobre o uso em outros textos do comentador brechtiano, volto a este dado construtivo adaptado ao perfil de seu texto de jornal, no caso seu "Folhynhaz da Prymavera”. Embora não só a partir dele, é bastante clara a posição assumida pelo personagem Glauber; assume o papel de comentador do momento político sempre que solicitado. Qualquer intervenção de outro personagem transforma-se na deixa para sua entrada como comentador dos fatos políticos. Deslocado de suas conjunturas geográficas e temporais, certos personagens provocam a voz reflexiva do personagem Glauber. É o caso da atriz portuguesa Carmen Dolores: "Estamos além da esquerda e da direita... Nossa dívida externa é fabulosa, existem mais de 40 milhões de habytantz em pobreza geral, outros 80 milhões em crize psico-econômico-sócio-político-fylozhopihyka.. A censura matou as artes nacyonyz" ${ }^{40}$. A resposta do personagem Glauber, intercalada pela pergunta de outro personagem (Lucas Fernandes, em referência ao artista do século XV de Salamanca), é um comentário sobre a situação que, sob sua visão, exige um misto de apoio à candidatura de Figueredo e a exigência de uma abertura cada vez maior que desembocaria nas eleições diretas:

\footnotetext{
${ }^{39}$ Glauber Rocha, Jango (tragedya em 3 atos), 1976. [Datiloscrito, 42 páginas, inédito, Tempo Glauber, Rio de Janeiro (RJ)].

${ }^{40}$ Glauber Rocha, "Folhynhaz da Prymavera", Folha de S. Paulo, São Paulo (SP), 26 ago. 1978, p. 30.
} 
"Glauber: Apesar do Gallup, na minha família a situação é a seguinte: minha mãe votaria no Euler, meu pai em Magalhães e Paula, se fosse brasileira, votaria em Magalhães e eu em Figueiredo...

Lucas Fernandes: Você não era Eulerista?

Glauber: Adoro o Euler... O problema é que ele apareceu depois do Figueiredo e Figueiredo é o candidato do Geisel. Fiquei ligado em Figueiredo, digamos miticamente, porque, segundo o 'Informe JB', eu, Figueiredo, Rita Lee, Sonia Braga, Delfim Neto e Paulo Brossard somos da família dos Touros... E tem mais: acho que deveria HAVER ELEIÇÕES DIRETAS..." ${ }^{\text {41 }}$.

Como se pode notar, as ideias presentes no texto de Glauber não representam o início de um percurso, mas o desdobramento, transformações e ratificação de outras ideias presentes em outros de seus textos.

Cabe avaliar algumas delas mais de perto.

Um pouco mais de um ano antes da publicação de "Folhynhaz da Prymavera", logo após receber a notícia de sua premiação no Festival de Cannes, com o filme Di Cavalcanti, Glauber dá um importante depoimento a Maria Lúcia Rangel, do Jornal do Brasil. Trata-se de uma entrevista-chave, pois seus subsídios permitem compreender de forma mais afinada os comentários posteriores de Glauber, principalmente os de 1978 e 1979. No campo cultural brasileiro, Glauber se mostra ressentido com sua incômoda situação em sua volta ao Brasil e registra dois motivos de sua não-aceitação entre parcela intelectual opositora: havia se tornado um crítico de produtores voltados para o filme comercial, que, segundo ele, estes tomavam empréstimo de dinheiro público através da Embrafilme para suas realizações dentro do mercado interno e não atendiam à demanda cultural necessária no momento; e, ao mesmo tempo, havia empreendido uma crítica a todos aqueles seus antigos companheiros, acusando-os de estarem encharcados de um espírito conformista com os rumos culturais que o país seguia. No campo político, suas interpretações levantavam a bandeira polêmica a favor dos militares. Perguntado sobre as lideranças militares, dizia:

"Eu tenho lido os discursos do Geisel e acho que são os melhores textos políticos que o Brasil tem atualmente. São mais importantes do que os discursos da Oposição e dos articulistas políticos. Os militares aboliram a escravidão, proclamaram a República, fizeram a Revolução de 22 e 30, sempre estiveram

\footnotetext{
${ }^{41}$ Glauber Rocha, "Folhynhaz da Prymavera", Folha de S. Paulo, São Paulo (SP), 26 ago. 1978, p. 30.
} 
intervindo para viabilizar o país. Os políticos criam as crises, usam o povo como massa eleitoral entre os Partidos que disputam o Poder e depois atribuem as responsabilidades aos militares. Isso é uma coisa que eu denunciei em Brasília. O Rui Barbosa foi o grande responsável, aqui, pela campanha antimilitarista. Então o negócio é o seguinte: só elogiam os militares quando estes estão servindo aos seus interesses. No momento em que Geisel afirma não ter compromisso com ninguém, é atacado pelo New York Times e pelo Pravda. Se Moscou e os Estados Unidos atacam Geisel ao mesmo tempo, não se pode dizer que ele é um representante do imperialismo nem o restaurador do Terceiro Reich, como andam dizendo, depois que fez acordo nuclear com a Alemanha. Eu não aceito esse tipo de crítica. Considero que a realidade do poder militar no Brasil é um dado histórico que deve ser analisado seriamente. As pessoas que hoje combatem o regime militar não merecem o meu respeito, porque defendiam este mesmo regime anos atrás" ${ }^{\prime 2}$.

Não resta dúvida que a declaração dada ao Jornal do Brasil reitera o apoio de Glauber à liderança militar à época. Mas é preciso ver mais de perto as razões disso, o que em parte sugerem pontos para o entendimento das críticas a ele imputadas. Sua concepção coloca em destaque Geisel, segundo ele, o líder que havia sinalizado com o processo de abertura política. Do mesmo modo, ele elege Figueiredo como responsável pela continuidade desse processo. Para o cineasta baiano, a distensão do regime levava, em questão de tempo, ao prenúncio da redemocratização. Em suas palavras, já havia se formalizado "um sintoma histórico positivo dentro da crise" ${ }^{\$ 3}$. Segundo ele, debates, antes proibidos, eram gerados e a imprensa em certo sentido já iniciava as discussões em torno do problema da censura. Antes de levantar algumas hipóteses e algumas interpretações em torno deste seu posicionamento político, é o caso de coletar mais um destes depoimentos. Na entrevista, concedida a Lúcia Rito, Glauber fornece pistas para que se compreenda como ele havia chegado às conclusões em relação aos militares:

"Estudo a história do Brasil e tenho uma vasta informação sobre a cultura e a política brasileiras. Os filmes que faço são produzidos pela realidade econômica, política e cultural do Brasil, e então posso me dar o direito de emitir opiniões

\footnotetext{
${ }^{42}$ Glauber Rocha em Maria Lúcia Rangel, "Um incômodo cineasta do terceiro mundo", Jornal do Brasil, Rio de Janeiro (RJ), 28 maio 1977, p. 10. [Depoimento].

${ }^{43}$ Glauber Rocha em Lúcia Rito, “Não me exijam coerência”, Veja, São Paulo (SP), 8 set. 1976, p. 4. [Depoimento].
} 
políticas sobre eventuais contradições antes de o general Geisel tomar posse e algumas coisas que falei mais ou menos se delinearam no quadro político brasileiro. Não aderi ao governo, porque não disputo o poder nem me interessa satisfazer a centros de poder, sejam eles do governo, de partidos ou de grupos econômicos. Eu posso então emitir opiniões independentes de conceitos vigentes" ${ }^{\prime 4}$.

Deve-se considerar que existe um eixo-comum presente nas suas declarações e no que depois ele escreveria nas páginas da Folha. Trocando em miúdos, talvez seja o caso de perguntar: que matéria histórica Glauber operacionaliza tanto nestas declarações como na forma com que aborda os projetos políticos do país em seus textos na coluna da Folha de $S$. Paulo?

Recorro ao que considero, entre os trabalhos recentes, um importante estudo na fortuna crítica de Glauber Rocha. Maurício Cardoso, em sua tese de doutorado sobre os filmes do exílio do cineasta baiano, ao analisar a estratégia narrativa de História do Brasil (1974) (este em co-autoria com Marcos Medeiros), comenta sobre a disposição de dois problemas centrais que motivavam o pensamento intelectual de uma geração no início dos anos 1970. Problemas, por sinal, que ainda reverberavam nos escritos de final de década de Glauber. São eles: a "nacionalidade como um dilema"45 e o método marxista importado e adotado para a análise da realidade local.

Segundo o estudioso, tal abordagem, tensão destes dois pólos e marca registrada também de Glauber escritor e Glauber cineasta, consistia em delinear um eixo de debate em torno do projeto intelectual que visava pensar os problemas da formação do Brasil. Um debate que se traduzia, de diferentes modos, pelo diálogo com as sínteses históricas de nossa formação, composta por ensaístas e intérpretes de grande envergadura de nossa realidade. A lista desses autores é grande e passa por trabalhos fundadores de Euclides da Cunha, Oliveira Lima, Gilberto Freyre, Caio Prado Jr., Sérgio Buarque de Holanda, Florestan Fernandes, só para ficar em alguns mais conhecidos. Embora saldo, muitas vezes, de uma leitura difusa e apressada, é bastante provável que Glauber soubesse avaliar o legado de tais intérpretes nacionais. Em suas interpretações históricas, o cineasta baiano carregava consigo uma base

\footnotetext{
${ }^{44}$ Glauber Rocha em Lúcia Rito, “Não me exijam coerência”, Veja, São Paulo (SP), 8 set. 1976, p. 4. [Depoimento].

${ }^{45}$ Maurício Cardoso, O cinema tricontinental de Glauber Rocha: política, estética e revolução (1969-1974), 2007, p. 183.
} 
comum com o ensaísmo construído principalmente desde os anos 1930, que, nas palavras de Maurício Cardoso, poderia ser equacionada pelo "legado colonial, o desenvolvimento econômico, a construção do Estado Nacional e a luta de classes numa organicidade social que conferiu uma feição original ao país”46.

É importante notar como o estudioso analisa a perspectiva de Glauber em História do Brasil em relação à participação militar na nossa história. Maurício Cardoso vai dizer que este filme do cineasta baiano está povoado de participações militares, de exércitos militares e tropas armadas. Nesse horizonte levantado, o pesquisador demonstra que a narrativa de História do Brasil, em relação aos militares, delimita dois “campos opostos”, cuja mediação é o "critério nacionalista": "de um lado, as ações militares de controle e repressão aos anseios populares, em geral, articuladas aos interesses de uma burguesia nacional associada ao capitalismo internacional e ao imperialismo; de outro, as investidas militares de caráter progressista ou revolucionário, de inspiração nacionalista e pautada em ações de vanguarda" 47 .

Não resta dúvida que mesmo ponto de vista é ainda detectável em outros tipos de textos glauberianos. Veja-se um desses casos. Em uma entrevista dada a Paulo Francis, para a revista Status, em março de 1975, é bastante esclarecedora a fala de Glauber a respeito do papel dos militares:

\begin{abstract}
"Quem analisa a História do Brasil, da proclamação da independência até hoje, vê que o Exército desempenhou em várias fases decisivas um papel progressista, como na abolição da escravatura, proclamação da República e na Revolução de 1930, cujo ciclo ainda não se encerrou. No nosso período, de luta entre oligarquias latifundiárias e burguesia industrial de um lado, e classes trabalhadoras e vanguardas intelectuais, de outro, o Exército é uma força moderadora.

O processo militar de 1964 passou por disputas entre grupos (Castelo Branco e Costa e Silva, para ficarmos na superfície), numa luta que envolveu toda a sociedade, direta ou indiretamente. A subida de Geisel é o resultado dessas contradições e a política dele, em 1974, é o primeiro sinal de uma détente, já visível nas eleições de novembro de 1974, que permitiram ao povo expressar
\end{abstract}

\footnotetext{
${ }^{46}$ Maurício Cardoso, O cinema tricontinental de Glauber Rocha: política, estética e revolução (1969-1974), 2007, p. 183.

${ }^{47}$ Maurício Cardoso, O cinema tricontinental de Glauber Rocha: política, estética e revolução (1969-1974), 2007, p. 190.
} 
oposição pelo voto. É desta progressiva reabertura que renascerão as possibilidades de independência econômica, política, e cultural no Brasil’"48.

É desse modo, portanto, a partir de uma visão em que pese o valor acumulado de figuras militares históricas de alta importância e com acentuada visão nacionalista, que Glauber institui um caminho para sua interpretação histórica em História do Brasil. O percurso histórico com que ele se compromete neste filme vai traçando dois caminhos possíveis para as forças militares, depois dos anos 1930 até a eclosão do golpe em 1964. De um lado, uma fração militar ligada aos setores conservadores, aqueles que seriam os representantes de uma força externa e imperialista e que estariam dispostos às alianças internas com as alas mais conservadoras da política e da classe dirigente nacional. De outro lado, a fração militar nacionalista, a qual Glauber considerava seguidora de um projeto político com visão nacional, de inspiração varguista ${ }^{49}$.

Presente no filme, tal concepção percorre a interpretação histórica de Glauber em seus demais textos de mesma época. Em outras palavras, o que estava contemplado em um filme como História do Brasil através de um balanço das forças presentes entre militares também se internalizava na sua produção escrita, explicitando por textos de jornais e cartas uma proposta de ação prática por meio do apoio aos militares nacionalistas. Ao que parece, Glauber, neste apoio, traçava um objetivo premente, por sinal bastante ambicioso do ponto de vista político: formar as bases nacionais desarticuladas depois de 1964. Sua avaliação procura demonstrar que os passos para uma efetiva transformação dos rumos do país e a reestruturação do valor nacional na cultura estariam intimamente ligados ao apoio a essas lideranças de militares nacionalistas. É desse modo que a figura de Ernesto Geisel se torna estratégica para Glauber. Considerado um legítimo representante de essa ala militar nacionalista, restava a ele declarar publicamente seu apoio ao general.

Voltando aos textos da Folha, aqueles cuja tônica é o pensamento político de Glauber, é nítido que tais artigos representem uma continuidade destas interpretações históricas feitas ao longo da década por seu autor. Se em História do Brasil, como identificado por Maurício Cardoso, nota-se uma estratégia política traçada na análise

\footnotetext{
${ }^{48}$ Glauber Rocha em Paulo Francis, "Glauber Rocha: entrevista concedida a Paulo Francis", Status, São Paulo (SP), mar. 1975, p. 16. [Depoimento].

${ }^{49}$ Cf. Maurício Cardoso, O cinema tricontinental de Glauber Rocha: política, estética e revolução (1969-1974), 2007, pp. 194-195.
} 
histórica em que seu autor projeta especial ênfase à força militar nacionalista e suposta capacidade desta de reelaborar novos caminhos para o país ${ }^{50}$, nos textos de colunista da Folha Glauber recupera as mesmas ideias trazidas do exílio, fazendo-as circular por aqui. Seu engajamento intelectual faz crer que os novos rumos do país poderiam surgir da aliança entre o quadro de seus perfis intelectuais que havia sido importante antes do golpe e o grupo de militares nacionalistas que detinham o poder naquele momento.

Pertencente a este quadro intelectual, Glauber vê em si mesmo um perfil compatível para se tornar um dos protagonistas das mudanças políticas. Um intelectual capaz de se tornar um porta-voz para negociar com o grupo nacionalista de militares. Hoje, olhando em retrospecto os textos produzidos por ele naquele momento de final de década, é com clareza que se nota que Glauber não soube avaliar "quando novos personagens entraram em cena”, para utilizar uma expressão de Eder Sader. Prova disto é que seus artigos pouco circundam a dinâmica dos novos movimentos populares que surgiam no momento, principalmente, na periferia de São Paulo; a formação do "Movimento do Custo de Vida"; o novo sindicalismo que se formava que colocava em crise o modelo tutelar do Estado e com ele as greves que surgem com força a partir daquele momento, principalmente na região do ABC paulista, entre outras mudanças observadas no interior das classes populares que se despontaram na vida política brasileira ${ }^{51}$.

No plano textual dos seus artigos elaborados para a Folha, talvez seja possível dizer que a perspectiva de olhar para si mesmo como um dos grandes personagens em cena crie uma voz autoral muito mais incisiva, em termos políticos, se comparada àquela presente em artigos dos anos 1960. É incisiva, porque, como crítico, ele não quer mais ser limitado pelo uso da terceira pessoa, nem tampouco invalidar-se por uma abordagem morna dos fatos; razão pela qual ele, como figura intelectual, se faz sempre presente em seus textos, assumindo de vez um suposto protagonismo político. É ainda incisiva, pois nela vêm à tona, no mesmo plano, personagens da cena cultural e da cena política para a manifestação de uma de suas teses; ambos se misturam com o objetivo de demonstrar uma raiz comum entre campo cultural e político.

\footnotetext{
${ }^{50}$ Cf. Maurício Cardoso, O cinema tricontinental de Glauber Rocha: política, estética e revolução (1969-1974), 2007, p. 196.

${ }^{51}$ Cf. Eder Sader, Quando novos personagens entraram em cena, 1995, p. 30.
} 
Nos três textos levantados da coluna da Folha para esta seção, tais posturas do autor ficam evidenciadas. Existem momentos em que Glauber transborda-se de seus textos para reafirmar a necessidade de mediação de intelectuais no mundo da política nacional. Neste caso, ele se coloca como o maior exemplo. Próprio de seu tom eloquente, há outros casos em que sua perspectiva histórica de análise do presente é totalizadora, sugerindo ao seu leitor uma única saída dos fatos.

Vejam-se dois desses três exemplos antes trazidos.

Em "Goal de Figueredo", por exemplo, Glauber perfila Figueiredo como o grande herói da abertura, afirmando que sua rejeição poderia ser um equívoco histórico, tal como acontecera, segundo seu ponto de vista, outras vezes na vida social brasileira. A representação de Glauber sugere que não mais exista a limitação entre o homem político e o homem de cultura. Nas suas palavras, as diferenças não se sustentam e todos deveriam prescindir de uma mesma preocupação com os rumos da nação, por isso a mistura deliberada entre políticos e artistas: "Figueredo foi rejeitado como Gilberto Gil, Gilberto Freyre, Jorge Amado, Caetano Veloso e Glauber Rocha. Figueredo lutou contra a repressão em todos os escalões: ele é a Chave da Abertura" ${ }^{52}$.

Em “Fomaluf”, embora Glauber proponha uma forma de texto com interlocução direta com o político Paulo Maluf, ainda fica o espaço privilegiado para a demonstração da relevância dos militares nacionalistas, que estariam lado a lado com os principais figurões de nossa cultura na visão de Glauber: "A Frente de Democratyzação Nacyonal é importante na medida em que obrigará Figueredo a pegar na bola com firmeza e responder com goals aos Desafios! Mas o Brasil precisa também de Euler, de Magalhães, de Teotônio, de Raimondo Faoro, de Darcy Ribeiro, de Celso Furtado, de Gilberto Freyre, de Golbery e de Ernesto Geisel"53.

Voltemos à tese de Maurício Cardoso para se refletir sobre uma última questão. O estudioso de Glauber levantou em seu trabalho uma hipótese que considero bastante profícua. Diz ele que o cineasta baiano ao longo da década de 1970 foi confirmando uma participação cada vez maior de si mesmo no universo diegético dos filmes. Das participações mais acanhadas presentes em Cabezas cortadas, Glauber inicia com Claro, em 1975 sua

\footnotetext{
${ }^{52}$ Glauber Rocha, “Goal de Figueiredo”, Folha de S. Paulo, São Paulo (SP), 17 jun. 1978, p. 30.

${ }^{53}$ Glauber Rocha, “Fomaluf”, Folha de S. Paulo, São Paulo (SP), 8 jul. 1978, p. 26.
} 
invasão à diégese, até resultar na maneira performática com que sua fala ocupa em $A$ idade $d a$ terra.

Maurício Cardoso chama a atenção para o modo como Glauber havia entrelaçado, tanto em História do Brasil como em filmes posteriores, tal como $A$ idade da terra (1980), sua biografia no "torvelinho das transformações do seu tempo" ${ }^{4}$. Questão, esta, que se traduzia em dois pontos principais para a análise: pelo traço pessoal da biografia de Glauber que permite observar os dados históricos por ele adotados em sua obra; e, ao mesmo tempo, a forma como Glauber se contaminava com o que havia de dado histórico de sua obra $^{55}$.

Deve-se observar, em seus textos de colunista da Folha, que o traço pessoal e biográfico parece se contaminar com o mundo dos fatos e das ações políticas voltado para uma periodização de cunho mais oficial. Daí se explica que seu tratamento do período entende que o valor democrático passava por um processo de redemocratização, que, em curso, era o resultado da distensão de Geisel e a abertura de Figueredo. Mesmo quando Glauber reconstrói personagens trazidos do mito, caso de Don Juan em "Folhynhaz da Prymavera", ele os transforma pela via do presente. Transforma-os, tais personagens, pela voz trançada ao momento histórico:

\begin{abstract}
"Don Juan: Dissolução dos Partidos. Criação de Cinco Partidos. Cinco Candidatos (ou menos, a depender das Co-Ligações dos Partidos). Concorreriam Euler, Figueiredo, Magalhães e um candidato jovem, na área dos 40 anos, independente das correntes dominantes... Talvez u'a MULHER... Insisto que o problema não se revolve com NOMES - mas com um PROGRAMAHUMANYZTA! Menos ideologia e mais Amor. Neste mês choramos e Oramuz a morte do Grande Vargas, o Pay da Patrya, cujo Ezpyryto ilumina e projete os destinos do Brazyl" ${ }^{\prime 56}$.
\end{abstract}

\footnotetext{
${ }^{54}$ Cf. Maurício Cardoso, O cinema tricontinental de Glauber Rocha: política, estética e revolução (1969-1974), 2007, p. 196.

${ }^{55}$ Cf. Maurício Cardoso, O cinema tricontinental de Glauber Rocha: política, estética e revolução (1969-1974), 2007, pp. 196-197.

${ }^{56}$ Glauber Rocha, "Folhynhaz da Prymavera", Folha de S. Paulo, São Paulo (SP), 26 ago. 1978, p. 30.
} 


\section{Intelectuais à brasileira por Glauber ou alguma coisa que veio de Iracema até Macunaíma}

Sergio Miceli, em seu já clássico estudo Intelectuais e classe dirigente no Brasil (1979), oferece uma síntese privilegiada do processo cultural entre as décadas de 1920 e 1940. Seu foco de análise recai sobre os intelectuais e suas relações, bem como suas estratégias lançadas, para alcançarem destaque e posições em carreiras intelectuais nos setores público e privado, em sua expansão de postos de trabalho. As contribuições do estudo de Miceli são muitas, mas uma delas, a meu ver, se destaca por trazer argumentos bastante válidos para o cerne da discussão acerca do grupo de intelectuais cooptados pelo Estado.

Trouxe o estudo de Miceli como referência para dizer sobre as tarefas políticas que engajaram gerações de intelectuais desde os tempos do Império. De um modo ou de outro, intelectuais ligados ao Estado sempre estiveram envolvidos nas demandas políticas solicitadas por seus representantes. Antes do regime Vargas, tais intelectuais dependiam quase que exclusivamente de chefes políticos oligárquicos. Depois de instituído o regime, dependiam muito mais de uma elite burocrática cada vez mais forte em termos políticos ${ }^{57}$. Enfim, a partir do estudo pioneiro de Miceli, o que se começa a notar com maior efeito é uma ligação bastante íntima entre classe intelectual e demandas políticas existentes na vida social.

Para o momento, cabe notar que a visão de Glauber - refiro-me aos seus textos de depois do exílio - privilegia o intelectual engajado com uma agenda política. Mas não qualquer agenda política. Nem qualquer perfil de intelectual. É o caso, sem dúvida, de se avaliar que tipo de intelectual estaria ele valorizando. Antes de adentrar nos comentários dos textos produzidos para sua coluna na Folha, abro espaço para debater um perfil intelectual por ele valorizado e um perfil intelectual por ele rejeitado, dando uma dimensão inicial do problema.

Trata-se de uma polêmica reavivada no ano de 1976: Alencar-Machado.

Glauber chega ao Brasil em 23 de junho de 1976, numa quarta-feira. Já no sábado, dia 26, o Jornal do Brasil publica uma página de sua entrevista, em que mais uma vez o cineasta baiano faz um de seus balanços. O primeiro em sua volta. Em pauta: o saldo final do exílio, as novas perspectivas para o cinema brasileiro de então e os valores presentes na vida intelectual brasileira. Perguntado, ao final, se existiria no momento uma saída possível

\footnotetext{
${ }^{57}$ Cf. Sergio Miceli, “Intelectuais à brasileira”, 2001, p. 198.
} 
para a crise vivida por nossa arte, Glauber dá a seguinte resposta: "O Brasil produz uma arte forte, viva, violenta, popular, colorida, erótica, barroca, tropical, generosa, e cuja característica principal é a sua indisciplina, seu antiacademicismo. Com exceção de Machado de Assis, que é o sistema da cultura reprimida, e por isso feito para a censura. Mas Guimarães Rosa, e Drummond não são, nem Oscar Niemeyer projetando Brasília. Eles estão além disso. Daí decorre o drama de todos os Estados que querem produzir uma arte à sua imagem, quando a arte é a anti-imagem, porque é outra imagem escondida. O charco burocrático não cria. A arte brasileira só pode existir a partir da sua indisciplina" ${ }^{38}$.

Dias depois, um novo depoimento no jornal alternativo Movimento, de São Paulo. E Glauber, nesta entrevista, desdobra a ideia, antes mencionada no Jornal do Brasil, sobre Machado de Assis, acrescentando outros elementos à polêmica: "E a estética só é grande quando é livre. E a principal característica da arte brasileira é sua indisciplina. Exemplo: Machado de Assis é um escritor que escreve para ser censurado, porque é um acadêmico. Então é o escritor por excelência responsável pela mediocridade; é um modelo que impõe uma mediocridade literária que imita um padrão. O censor entende Machado de Assis. O Guimarães Rosa é um escritor para não ser censurado, porque o censor está diante de uma língua nova. Então, um artista que quer ser censurado apresenta um estilo suscetível de ser censurado [...] O responsável pela censura é Machado de Assis, que determina um tabu linguístico, tremendamente moralista e conservador" ${ }^{25}$.

Duras palavras ao escritor de Dom Casmurro. Tão duras que há de se entrever que por detrás delas estejam demonstrações e rejeições de compatibilidades do que Glauber considera um autêntico intelectual nacional. As declarações dadas ainda sob o impacto de sua chegada ao Brasil apenas registram a ponta do iceberg.

Numa das reações que suas palavras suscitaram destaca-se a polêmica dele com o então editor de cultura do semanário Movimento, Flávio Aguiar. Em 9 de agosto de 1976, neste mesmo semanário, o crítico literário porto-alegrense alfineta Glauber com o artigo de longo título: "E geme o sino em lúgubres responsos Pobre Glauber! Pobre Glauber! (ou: 'Nem Lênin, nem Stalin, nem Marx, nem mesmo Machado de Assis'. E muito menos Glauber Rocha)". Tal título, tomado do último verso de Alphonsus de Guimaraens, do poema "A

\footnotetext{
${ }^{58}$ Glauber Rocha em Mary Ventura, "Glauber Rocha de volta”, Jornal do Brasil, Rio de Janeiro (RJ), 26 jun. 1976, p. 1. [Depoimento].

${ }^{59}$ Glauber Rocha, em Narciso Lobo, "Nem Lênin, Nem Mao, nem Stalin, nem mesmo Machado de Assis", Movimento, São Paulo (SP), 19 jul. 1976, p. 19.
} 
catedral”, em que o próprio poeta a si evocava a angústia do dia que se passava, sob os badalos do sino da igreja: "Pobre Alphonsus! Pobre Alphonsus!", registra uma intenção de Flávio que se confirma com o desenrolar do seu artigo. Flávio Aguiar, neste artigo, diz não querer desentranhar o Glauber de ontem, personagem central dos nossos avanços cinematográficos, para desvelar esse Glauber de então, "disposto a ser uma espécie de enfant terrible de nosso vazio cultural”"60. Sua estratégia foi outra. Ao invés de utilizar a mesma moeda de troca de Glauber, Flávio apenas propõe que esperamos. Sejamos pacientes. No aguardo para que, segundo ele, "esse Glauber aprenda, como aprendemos, com o outro" ${ }^{1}$. Que aprendesse, por exemplo, com seu próprio personagem Antonio das Mortes, que depois de dois filmes, aprendeu a enxergar alguns palmos além do próprio nariz. Flávio ainda justifica que a atitude de Glauber só vinha provar algo. Diz ele: “o cinema brasileiro precisa de cada vez menos de enfants terribles, que servem de diversão muitas vezes a quem olha a arte como diletantismo, e muito mais de gente adulta, com o discernimento crítico, que, com criatividade, espírito combativo, seja no drama ou na sátira, saiba distinguir o sul do norte, o leste do oeste e o Machado da tesoura" ${ }^{\prime 2}$.

A réplica, até certo ponto exagerada de Glauber, vem pelas páginas do Pasquim. Acusa o jornal Movimento de fazer sensacionalismo com seu nome: "vamos vender a cabeça da fera pra vender mais jornal”33. Mas é na questão Machado de Assis que Glauber nota uma espécie de censura por parte do semanário. Diz ele, em alto e bom som:

“Se o pessoal do 'Movimento’ estivesse no poder Glauber Rocha cineasta
revolucionário do Terceiro Mundo seria fuzilado porque esculhambou Machado
de Assis. Porque veio um crítico chamado Flávio de Aguiar, inocente útil a serviço
de Jean Claude Bernardet, anunciar em dobres fúnebres nas páginas de
'Movimento' minha morte [...] Vivemos num país democrático onde a censura do
governo permite que eu publique materialismo dialético onde o 'Movimento' em

\footnotetext{
${ }^{60}$ Flávio Aguiar, "E geme o sino em lúgubres responsos Pobre Glauber! Pobre Glauber! (ou: 'Nem Lênin, nem Stalin, nem Marx, nem mesmo Machado de Assis'. E muito menos Glauber Rocha)", Movimento, São Paulo (SP), 9 ago. 1976, p. 15.

${ }^{61}$ Flávio Aguiar, "E geme o sino em lúgubres responsos Pobre Glauber! Pobre Glauber! (ou: 'Nem Lênin, nem Stalin, nem Marx, nem mesmo Machado de Assis'. E muito menos Glauber Rocha)", Movimento, São Paulo (SP), 9 ago. 1976, p. 15.

${ }^{62}$ Flávio Aguiar, "E geme o sino em lúgubres responsos Pobre Glauber! Pobre Glauber! (ou: 'Nem Lênin, nem Stalin, nem Marx, nem mesmo Machado de Assis'. E muito menos Glauber Rocha)", Movimento, São Paulo (SP), 9 ago. 1976, p. 15.

${ }^{63}$ Glauber Rocha, "Querem me matar (ou, votem na Arena)", O Pasquim, Rio de Janeiro (RJ), 13-19 ago. 1976, p. 14.
} 
nome da Revolução brasileira pede minha cabeça porque eu esculhambei com Machado de Assis. De quem é a censura?" ${ }^{64}$.

Se o próprio Pasquim abriu seu espaço para a tréplica de Flávio Aguiar ${ }^{65}$, que ocupou o espaço para se defender das acusações de Glauber quanto à censura de Movimento em relação a sua entrevista, foi nas páginas deste semanário carioca que Glauber continuou suas reações contra Machado. Passamos mais perto por suas novas reações. Coincidência ou não, ao que tudo indica o cineasta baiano fora ainda mais motivado por uma discussão vinda diretamente de Brasília, das tribunas do Congresso Nacional. Em primeiro de setembro daquele ano, o senador Luiz Viana, da Arena da Bahia, também acadêmico da ABL, fez um longo discurso em que expressa uma antiga celeuma: deveria Machado de Assis ser o patrono das nossas letras ou o papel seria de José de Alencar? Em andamento naquela Casa e já aprovado pela Câmara dos Deputados, o projeto de autoria do deputado Alberto Lavinas declarava-se em favor de Machado. Diferente, Luiz Viana se colocava a favor de José Alencar, segundo ele, o "inconteste criador da literatura brasileira"

O discurso de Luiz Viana, cuja repercussão também gerou matéria no Jornal do Brasi $^{7}$, cerca o problema sem estabelecer um confronto entre os dois escritores. Tratava-se, como frisou, de atribuir a um deles o lugar que lhe era de direito. Um lugar dedicado a José de Alencar. Um lugar que "lhe competia na vida, na história e na formação das nossas Letras" ${ }^{\prime 6}$. Para o senador, entre os motivos da autêntica brasilidade adquirida por José de Alencar estaria seu estilo, de uma língua que ele mesmo criou pelas singularidades sintáticas e vocabulares do falar brasileiro, de um pioneirismo, enfim, que o libertava dos laços de dependência com o mundo lusitano. Nada, desse modo, parecia mais justo para o político que, mesmo com a admiração incontestável por Machado de Assis, pudesse valer seu voto parlamentar e proclamar José de Alencar como o verdadeiro patrono das nossas letras.

\footnotetext{
${ }^{64}$ Glauber Rocha, "Querem me matar (ou, votem na Arena)", O Pasquim, Rio de Janeiro (RJ), 13-19 ago. 1976, p. 14.

${ }^{65}$ Cf. Flávio Aguiar, “A tréplica de Flávio a Glauber”, O Pasquim, Rio de Janeiro (RJ), 10-16 set. 1976, p. 19.

${ }^{66}$ Luiz Viana em Diário do Congresso Nacional, Seção II, Brasília (DF), 2 set. 1976, p. 5336. [Discurso do senador Luiz Viana, proferido em 1 set. 1976].

67 "Senador veta Machado e afirma que Alencar deve ser patrono das Letras", Jornal do Brasil, Rio de Janeiro (RJ), 2 set. 1976.

${ }^{68}$ Luiz Viana em Diário do Congresso Nacional, Seção II, Brasília (DF), 2 set. 1976, p. 5337. [Discurso do senador Luiz Viana, proferido em 1 set. 1976].
} 
Discurso feito pelo senador na quarta-feira, dia 1, repercutido no dia 2, e Glauber já de opinião formada no dia 6 de setembro. Ocasião que escreve e publica o artigo " $\mathrm{O}$ Guarany' e 'Dom Casmurro' ou a competição entre Iracema e Capitu pelo título de Misse Brazyl" para o Jornal do Brasil. Por se deter mais na polêmica, tal texto é chave para se detectar evidências mais substanciais da posição assumida pelo cineasta, deixando clara sua opção pelo tipo intelectual de José de Alencar e, ao mesmo tempo, negando o modelo intelectual de Machado de Assis. Resta saber as razões disso.

O artigo de Glauber começa pela digressão a uma conversa que ele havia tido, na França, com o crítico Roberto Schwarz, mais Leandro Konder e José Guilherme Merquior. Da conversa, o autor de Terra em transe conclui que há uma indisposição da crítica em relação ao nosso romantismo. Deixando transparecer que tal crítica está muito mais propensa a fundar o nosso verdadeiro romance por Machado de Assis, Glauber escreve, para em seguida contestar tal afirmação: "a tese geral de nossa crítica literária, não conheço discordantes, é a de que o nosso Romantismo não passa de reprodução da Europa. O índio alencariano ou gonçalvista não passa de um bom selvagem do Jango Jaca Russó”69.

Os motivos de desagrado para com Machado de Assis, segundo Glauber, é sua carreira política pouco engajada, mesmo medíocre. Nesta perspectiva, toda a desenvoltura de Machado em galgar posições sociais em uma sociedade tão pouco permeável, quanto era o Rio de Janeiro daquele fin de siècle, não surtia nem um efeito social mais imediato na visão de Glauber. Tudo que lhe restava, assim, era o prestígio literário, marcado pela criação já em fase madura da Academia Brasileira de Letras e a constituição de uma "Legislação Estética, Apanágio da Mediocridade Parnasiana! Academia Símbolo da Última Flor de Lácio Oh Inculta e Bela!"70. Glauber busca construir um Machado vulnerável ao mundo político, um autor que morre velho, cercado de amigos e protegido por um neutralismo das posições políticas: "Machado serviu ao Império e à República, a liberais e conservadores, nunca sujou as mãos nas senzalas, falou contra arte regionalista, negou a felicidade, viu o Brazyl com os olhos de Bentinho" ${ }^{\text {"11 }}$.

\footnotetext{
${ }^{69}$ Glauber Rocha, “'O Guarany' e 'Dom Casmurro' ou a competição entre Iracema e Capitu pelo título de Misse Brazyl”, Jornal do Brasil, Rio de Janeiro (RJ), 6 set. 1976, p. 10.

${ }^{70}$ Glauber Rocha, “'O Guarany' e 'Dom Casmurro' ou a competição entre Iracema e Capitu pelo título de Misse Brazyl”, Jornal do Brasil, Rio de Janeiro (RJ), 6 set. 1976, p. 10.

${ }^{71}$ Glauber Rocha, “'O Guarany' e 'Dom Casmurro' ou a competição entre Iracema e Capitu pelo título de Misse Brazyl”, Jornal do Brasil, Rio de Janeiro (RJ), 6 set. 1976, p. 10.
} 
De outro lado, o perfil intelectual construído por Glauber para José de Alencar ganha contornos épicos. Homem de posição política firme, apoiando o imperador quando fosse necessário, mas também entrando em desacordo em certos momentos, Alencar é visto como um intelectual capaz de ser aceito na corte pela excepcionalidade de seu talento tão apenas. Pois longe da elegância oratória de homens de corte, Alencar seria o "boêmio, playboy, dandy, político, malandro", carregando consigo, segundo suas palavras, as "taras nordestinas" 72 .

Em contraponto ao que fora Machado, o cineasta inscreve Alencar como um desbravador do mercado interno das letras. Um escritor que conseguia equilibrar na balança a vida pública e política e o investimento de tempo e talento no mundo das artes. Não só isso. Para Glauber, era ainda um defensor do ideário de liberdade. Certamente, sem conhecer suas cartas dirigidas ao imperador a favor da escravidão ${ }^{73}$, o cineasta baiano formulava um perfil de cidadão justo e político exemplar para Alencar. Um político que proibia a venda de negros, sob pregão, em lugar público; um político que enfrentava quem pudesse ser dentro das cercanias do poder: "seus diálogos com Dom Pedro II são de homem pra homem, em nenhum repique Alencar se rebaixa diante do Grande Português"74; um escritor que foi o que mais avançou diante da invasão de romances e dramas estrangeiros, no Rio de Janeiro do século XIX: “O Guarany fez o mesmo, ou mais, sucesso popular do que Os Miseráveis, de Victor Hugo, numa época em que o teatro era ruim, não tinha cinema e a novela era o folhetim"75.

A tendência de Glauber ao analisar o perfil intelectual de José de Alencar é trazêlo à lume a partir de sua visão contemporânea dos fatos. Neste redemoinho de perspectivas, é evidente que sua atualização delineia características no escritor de Iracema fora do seu tempo. Basta levantar os tipos alencarianos previstos por Glauber. O Alencar subversivo com o mundo político, o Alencar revolucionário e o Alencar feminista são apenas construções que têm muito da época vivida pelo cineasta e do próprio perfil que Glauber considerava mais adequado para um intelectual de nossa cultura. É desse modo que o perfil intelectual de

\footnotetext{
${ }^{72}$ Glauber Rocha, “'O Guarany’ e 'Dom Casmurro’ ou a competição entre Iracema e Capitu pelo título de Misse Brazyl”, Jornal do Brasil, Rio de Janeiro (RJ), 6 set. 1976, p. 10.

${ }^{73}$ Cf. José de Alencar, Cartas a favor da escravidão, 2008.

${ }^{74}$ Glauber Rocha, “'O Guarany’ e 'Dom Casmurro’ ou a competição entre Iracema e Capitu pelo título de Misse Brazyl”, Jornal do Brasil, Rio de Janeiro (RJ), 6 set. 1976, p. 10.

${ }^{75}$ Glauber Rocha, “'O Guarany’ e 'Dom Casmurro’ ou a competição entre Iracema e Capitu pelo título de Misse Brazyl”, Jornal do Brasil, Rio de Janeiro (RJ), 6 set. 1976, p. 10.
} 
Alencar torna-se o seu próprio espelho de vida intelectual. E Alencar e Machado espelhos da política nacional, sob sua concepção: “Alencar, um brasileiro típico candidato do MDB, é defendido por Luiz Viana, que não reconhece Machado patrono da velha bossa da Arena [...] Machado perde as eleições. Sua literatura é água encanada. A literatura de Alencar é o encontro do Negro com o Solimões"76.

Glauber segue por um campo minado. Ao mesmo tempo em que separa Machado de Assis e José de Alencar em setores distintos de ação prática na vida intelectual dos seus respectivos tempos, ele também define uma opção sua desta mesma vida prática para o seu próprio tempo. Aliás, apresentá-los, tais perfis, como água e vinho, foi um caminho discutível de elaboração. Basta notar algumas repercussões de várias ordens em textos de época $^{77}$. Porque, diga-se bem, a separação talvez não seja das mais fáceis de ser realizada, haja vista a permeabilidade de tempo histórico que ambos os escritores vivenciaram. A propósito, como a mão e a luva, a metáfora criada por Flávio Aguiar oferece uma interpretação mais sóbria para o caso: "Machado e Alencar são vinhos da mesma pipa, ainda que de safras diferentes"78. Mas há de se salientar, por outro lado, que Glauber também não buscava a sobriedade acadêmica na análise dos fatos. E sim a partidarização entre um e outro perfil. É desse modo que seria possível definir o seu intelectual de preferência por dois fatores: este não seria completo se apenas estivesse vinculado ao engajamento panfletário. Nem também cumpriria seu papel se apenas estivesse preso à própria prática de sua arte - sua arte por ela mesma. Alencar, portanto, é seu protótipo legítimo e nacional. Seu apoio para futuras observações.

Como se pode observar, a polêmica Machado-Alencar alimentada por Glauber fala muito além dos dois escritores. Sob seu próprio ângulo, frisa-se, ele polariza por dois perfis intelectuais: de um lado um suposto artista nacionalista e de outro o mito do artista omisso com os problemas nacionais e só preocupado com as sinecuras e os rendimentos que dela derivassem. Tanto Alencar como Machado, nesse horizonte de interpretações, tornam-se chave de interpretação para suas leituras de trajetórias. Glauber prosseguiria, em ano seguinte, em 1978, com os seus artigos de perfis intelectuais, dentro da coluna da Folha de $S$. Paulo.

\footnotetext{
${ }^{76}$ Glauber Rocha, “'O Guarany’ e 'Dom Casmurro’ ou a competição entre Iracema e Capitu pelo título de Misse Brazyl”, Jornal do Brasil, Rio de Janeiro (RJ), 6 set. 1976, p. 10.

${ }^{77}$ Cf. Flávio Aguiar, "Alencar e Machado, uma falsa polêmica”, Movimento, São Paulo (SP), 20 set. 1976, p. 18.

${ }^{78}$ Flávio Aguiar, “Alencar e Machado, uma falsa polêmica”, Movimento, São Paulo (SP), 20 set. 1976, p. 18.
} 
Vejamos.

Como era de se esperar, as críticas de Glauber a Machado continuaram a aparecer na imprensa. Dessa vez, estampadas nas páginas da Folha. Em 3 de junho de 1978, no texto "Limite", o tema inicial de sua discussão, motivado pela oportunidade de Glauber ter assistido pela primeira vez o filme (homônimo ao título do artigo) de Mario Peixoto, é a decadência. Ocasião em que Glauber julga Limite (1931) como "produto de intelectual burguês decadente" ${ }^{\text {79 }}$. Na discussão sobre o filme, Glauber encontra a brecha para a crítica a Machado de Assis. Não haveria, segundo ele, exemplo maior de um decadente em nossas artes e em nossa cultura do que o autor de Memórias póstumas. Neste sentido, ele faz supor que o gesto de decadência presente na vida e obra do escritor fluminense advinha da omissão para com o mundo, revolvendo-se, como se sabe, uma velha crítica, e já ultrapassada naquele fim de década, dirigida a Machado de Assis. Não é novidade que Glauber é passional. Sempre que pode ele dá uma dimensão pessoal às suas defesas. Veja-se uma clara demonstração de sua rejeição a Machado e a demarcação de uma de suas preferências: “o psicologismo satírico de Machado suprime a dramatyka luta de classes em nome dos minuetos ritualísticos do Segundo Ymperyu e por isso interrompi a leitura de 'Quincas Borba' e abri as delirantes páginas de 'Palmeiras Selvagens', romance de William Faulkner que o coloca o Heroy entre a Dor e o Nada" $"$.

Uma semana depois, em 10 de junho de 1978, as críticas continuam no artigo "Kranyo". Estas, muito mais contundentes que as anteriores. Para Glauber, em Machado de Assis, diferente de Alencar, há o compromisso com as elites. Diz ele:

\footnotetext{
"Enquanto as elites burguezas de D. Pedro II são contestadas pelas utopyas de José D’Alenkar, Gonçalves Diaz. Kastro Alves, Álvares de Azevedo, Kazimiro de Abreu - Machado de Assiz fetichyza os rituais decorrentes da kort.

Os signos de Machado são comprometidos com o liberalyzm escravocrata (...'uns crioulos de Mynas...' em Quincas Borba) - elegendo deliberadamente a dramaturgya da casa grande como centro de seu genyo" ${ }^{\prime 1}$.
}

Falar que Machado inclui a casa-grande como centro de sua literatura, no fundo, trazia dois efeitos para a caracterização do escritor fluminense. Tratava-se, nesta visão criada

\footnotetext{
${ }^{79}$ Glauber Rocha, "Limite”, Folha de S. Paulo, São Paulo (SP), 3 jun. 1978, p. 30.

${ }^{80}$ Glauber Rocha, "Limite", Folha de S. Paulo, São Paulo (SP), 3 jun. 1978, p. 30.

${ }^{81}$ Glauber Rocha, “Kranyo”, Folha de S. Paulo, São Paulo (SP), 10 jun. 1978, p. 32.
} 
pelo colunista, de um autor apenas preocupado com o mundo de pompas e etiquetas da elite carioca, quando, na verdade, hoje sabemos que a entrelinha de Machado havia falado muito do que se supunha ele não ter falado. Além disso, para Glauber haveria uma tendência de Machado como escritor ao esquecimento da própria condição de mulato, não levando em conta, dessa forma, quaisquer ressonâncias vindas do mundo das senzalas. Daí Glauber, em mais de uma vez, chamá-lo, sob o vocabulário marxista, de um escritor alienado. Daí ele caracterizá-lo como um escritor mistificado, cuja obra, segundo o cineasta, "farfalham rendilhotas, velas do bolo, novela de Janet K. Clair, alienação mistificada pela crítica naturalista" 82 .

Sob certo ângulo do colunista, Machado de Assis é um fragmento de nossa literatura mais conservadora. Não só isso. Ele carregaria consigo também uma crítica favorável que estaria amparando uma visão falseada da nossa vida social e cultural. Razão que obrigava o cineasta, por certo, a confrontar a crítica de alguns machadianos com sua própria posição pouco conciliatória com Machado de Assis. É o caso de se ler com atenção o trecho a seguir, para que se possa dedilhar um breve comentário: "Com a conversão de Machado ao lyberalysmo ezkolaztyk d'Akademya Brasyleyra de Letraz, fundou-se a rezyztencya a revolução kultural: tese de que os romantykuz são repetecos do romantyzmo francês, Jorge Amado escreve mal, Gylberto Freyre fascista etc." ${ }^{{ }^{83}}$.

No centro do referido trecho, há um problema que Glauber levanta, cuja defesa sua vai em sentido contrário. Refiro-me à tese não aceita por ele de que os românticos incorporam o modelo de romance francês do século XIX. Seu horizonte de debate enxerga a crítica de Roberto Schwarz, então recém-lançada. Lembre-se que Ao vencedor as batatas é de 1977 e o texto de Glauber é de 1978. Época, portanto, em que as ideias de Schwarz ainda são recepcionadas no âmbito brasileiro.

Parece nítido que Glauber está contra a tese inscrita em uma das partes de $A o$ vencedor as batatas, sobretudo aquela em que o crítico aponta as variadas respostas de Alencar na incorporação do molde europeu, que combinado à rica matéria local, produz uma série de efeitos, segundo ele, nem sempre bem-sucedidos sob a perspectiva literária. Há de se colocar que toda a construção de Glauber em defesa de Alencar poderia ruir-se, diante do

\footnotetext{
${ }^{82}$ Glauber Rocha, "Kranyo", Folha de S. Paulo, São Paulo (SP), 10 jun. 1978, p. 32.

${ }^{83}$ Glauber Rocha, "Kranyo”, Folha de S. Paulo, São Paulo (SP), 10 jun. 1978, p. 32.
} 
método avassalador do crítico. É provável que entre as passagens mais indigestas para Glauber da obra de Schwarz esteja o seguinte trecho:

\begin{abstract}
"Chega o romancista, que é parte ele próprio desse movimento faceiro da sociedade, e não lhe copia as novas feições, copiadas à Europa, como as copia segundo a maneira européia. Ora, esta segunda cópia disfarçada, mas não por completo, a natureza da primeira, o que para a literatura é um infelicidade, e lhe acentua a veia ornamental. Adotando forma e tom do romance realista, Alencar acata a sua apreciação tácita da vida das idéias. Eis o problema: trata como sérias as ideias que entre nós são diferentes; como se fossem de primeiro, ideologias de segundo grau. Soma em conseqüência do lado empolado e acrítico - a despeito do assunto escandaloso - desprovido da malícia sem a qual o tom moderno entre nós é inconsciência histórica. Ainda uma vez chegamos ao nó que Machado de Assis vai desatar" ${ }^{\prime 4}$.
\end{abstract}

O trecho se torna indigesto a Glauber, pois o crítico ao mesmo tempo em que destaca o aspecto imitativo da obra alencarina também registra que entre nós apenas o tom moderno e malicioso de Machado teria conseguido superar de forma mais crítica tal inconsistência. Se Glauber institui Alencar como revolucionário das nossas letras - para ficarmos num termo moderno de uso constante nos escritos do autor de Terra em transe-, é evidente que aceitar o influxo externo na modulação da literatura deste escritor romântico tornava-se um disparate, um contrassenso para o cineasta. Ao contrário de Schwarz, a perspectiva de Glauber dispõe Alencar de uma malícia e de um trato original com a brasilidade a ponto de transformá-lo, como notado antes, no grande patrono das nossas letras e das nossas artes. Da mesma forma que Roberto Schwarz nota um defeito na "grandiloquência séria e central da obra alencarina" ${ }^{85}$, cuja solução, segundo ele, viria com Machado de Assis e sua tonalidade grotesca, demonstrando que este sabia tirar proveito de um desajuste naturalmente cômico, em Glauber se nota o oposto em sua formulação. É a grandiloquência na abordagem, ajustada à cor local, que faz da obra alencarina alcançar sua dimensão épica e de transformação e, por consequência, fixação da forma do romance nacional. Sempre longe de uma neutralidade, isso só reforça que em Glauber falar de Machado é falar de Alencar e vice-versa. Falar da qualidade intelectual de um, no caso

\footnotetext{
${ }^{84}$ Roberto Schwarz, Ao vencedor as batatas, 2000, pp. 46-47.

${ }^{85}$ Roberto Schwarz, Ao vencedor as batatas, 2000, p. 50.
} 
Alencar, é deixar à vista os defeitos de outro, os de Machado. Ainda sim, sem esquecer que existem casos, como veremos a seguir, em que falar de um perfil intelectual é remetê-lo ao mito fundador, ao caso do perfil construído do patrono das nossas artes, conforme se disse.

Em 23 de setembro de 1978, ele escreve o artigo intitulado "Makunayma (1)", a primeira parte de um texto dedicado ao cineasta Joaquim Pedro de Andrade, autor do famoso filme Macunaíma, de 1969. A imprecisão com que Glauber lapida o perfil intelectual de Joaquim Pedro de Andrade tem sua razão de ser. Os fragmentos que desenham os contornos do seu personagem contemporâneo compõem um mosaico sob duas dimensões construtivas: a luta coletiva do autor de Os inconfidentes, cujo embate o ligava ao mundo do Cinema Novo, e o rigor e apego individual na ordem operacional da construção de sua obra multifacetada, ramificação, por assim dizer, poderosa deste mesmo Cinema Novo.

Espécie de um tipo alencariano, Quincas, como era chamado o cineasta de Macunaíma no ambiente carioca, é observado por Glauber como um intelectual que não se reserva à atuação apenas no campo cinematográfico. Suas filiações ultrapassam em larga escala o limite de uma arte apenas. A lista de Glauber é interminável. É discípulo de Plínio Sussekind Rocha, é ligado a Saulo Pereira (este, por sua vez, estivera ligado a Mario Peixoto do mitológico Limite), faz parte da "igreja de Octávio de Faria" ${ }^{86}$, é da turma adepta das críticas de Vinicius de Moraes e de Alex Viany, e ainda por cima é filho de Rodrigo Melo Franco de Andrade, um dos fundadores do que hoje conhecemos por Instituto do Patrimônio Histórico e Artístico Nacional (IPHAN). Longe de servir para demonstrações da ligação do cineasta com a elite carioca, a lista de filiações numerada por Glauber presta-se para salientar o talento individual de formação heterogênea que justificava uma obra que ultrapassava a própria condição social do cineasta de $O$ padre e a moça. O que não causa nenhum espanto que Glauber escreva a respeito de Quincas, em certo momento do seu texto o seguinte: "o aristocrata ia ao povo", pois, afinal, "era povo. Rompia com a legenda de que se tratava de um esnobe que não bebia água em botequim pra não contrair moléstias populares nos copos" $" 87$.

No segundo artigo dedicado a Joaquim Pedro de Andrade, o cineasta baiano dá prosseguimento às ideias tratadas no primeiro texto. Reitera-se a figura de aristocrata que vai ao povo. Para isso, nada parece se ajustar melhor à tal imagem do que remeter, em plena

\footnotetext{
${ }^{86}$ Glauber Rocha, "Makunayma (1)", Folha de S. Paulo, São Paulo (SP), 23 set. 1978, p. 32.

${ }^{87}$ Glauber Rocha, "Makunayma (1)", Folha de S. Paulo, São Paulo (SP), 23 set. 1978, p. 32.
} 
sintonia, o autor, seu engajamento, e obra, uma das mais simbólicas representantes do Cinema Novo. Modelar, portanto, seria o que havia se construído e entrevisto pela representação de Macunaíma, um filme de considerável sucesso de público:

\begin{abstract}
“'Macunaíma’ é o Klymax da experiência kyno-tropykalyzta de um cineasta que conquistou, pela comédia an-tro-po-fa-gi-ka, um público dominado, poluído, sob paternylização demagogykrymyna de críticos inspirados por Harry Stone, Jack Valenti, Pedro Tatlebaum e outros representantes dos interesses multinacionais que visam destruir as possibilidades de uma Indústria que 'conquiste' e não 'explore' o público, pratica dos pornô-historicistas que se identificam aqueles intelectuais desejantes de uma Arte Ruin ao alcance de todos...

Porque recusa o comercialismo criminal contra a cultura popular e ao controle estético-político dos Partidos ou Igrejas... O Kynema Novo, caminho ORYGYNAL, sofre violento boicote há 20 anos, dai ser redundante a atual campanha contra a Embrafilme"
\end{abstract}

Glauber compõe um estilo individual e épico para Joaquim Pedro de Andrade. Como sua característica marcante, está o seu estilo anticomercial, no sentido daquele que se recusa a trocar a ideia por um preço. Um estilo que, como consequência, se encaixaria no estilo coletivo do Cinema Novo. Ao ponto de a mistificação de personagens dos filmes do cineasta carioca se juntar à mistificação do próprio autor.

O texto de Glauber cria um jogo para Joaquim: se seus heróis personagens passam por protótipos da sociedade brasileira, desde intelectuais de renome, como, por exemplo, Manuel Bandeira e Gilberto Freyre dos primeiros filmes de curta-metragem, passando pela lenda mítica de Macunaíma, e ainda interpreta uma figura popular como Garrincha, é porque em todos eles há o personalismo de Joaquim, que soube moldá-los ao seu estilo e tonalidade, dando lhes, aos personagens, uma dimensão épica e central para a interpretação da vida nacional em seus principais momentos. Tornava-se, com isso, a "coluna mestra do Kynema Novo Brazyleyro"89. Essa simbiose entre as dimensões da representação dos personagens e a dimensão da representação do intelectual talvez fique mais evidente em um trecho selecionado:

\footnotetext{
${ }^{88}$ Glauber Rocha, "Makunayma - 2”, Folha de S. Paulo, São Paulo (SP), 28 out. 1978, p. 40.

${ }^{89}$ Glauber Rocha, "Makunayma - 2", Folha de S. Paulo, São Paulo (SP), 28 out. 1978, p. 40.
} 
"Bandeira, Gylberto, Gatos desencourados por capitães de areia nas favelas cariocas, Padre foge com Moça perseguidos pelo fanatismo católico subdesenvolvido das Mynas Geraes decadentes, Macunaíma o herói sem nenhum caráter do Modernysmaryandandrá, Inkofidentes da Heuztórya do Brazyl e casais de várias classes em Guerra Conjugal.

Qual a relação entre

Manuel Bandeira

Gylberto Freyre

Gatos

Pivetes

Padre

Moça

Macunaíma.

GARRINCHA é Makunayma Negro

Tyradentes (Joaquim seria Tomaz Antonio Gonzaga e Cristina Axé Marília de Dirceu).

Tyradentez é Makunayma Louro.

Joaquim Pedro foi preso algumas vezes, sob acusações de 'Karakter polytyk'

[...]Se de Manuel;Gilberto a Couro de Gato/Padre;Inconfidentes/Guerra há um Pedro, há um Joaquim em Macunaíma, e um J. Pedro em Garrincha.

Andrade monta estas contradições: Padre um quarteto, Macunaíma uma Synfonya, Inconfidência operística épica, Guerra cômica dos sexos" ${ }^{\prime 0}$.

Não há sombra de dúvida que Glauber aproxima Joaquim Pedro de Andrade da figura épica que se construiu em torno de José de Alencar. Não sem razão. Isolado e ainda crente de que seria capaz de reorganizar em termos programáticos o grupo de cinemanovistas de maior destaque, Glauber viu na estratégia de abordar um de seus integrantes, talvez o mais visível dos herdeiros da tradição literária modernista em nosso cinema, uma cartada de mestre: ao mesmo tempo em que ele propunha uma nova aliança com um dos seus mais fortes representantes de seu mais saudoso passado, ele também registrava a continuidade e ramificação no cinema, pela primeira vez na nossa história cultural, da reconhecida e consagrada tradição literária moderna. A quem quisesse ouvir, Glauber só vinha confirmar uma ideia sua: do mesmo modo que Alencar havia colocado a nação no rol de produtores da forma romanesca, o Cinema Novo conseguira alçar a nação entre os mais distintivos produtores de cinema moderno.

\footnotetext{
${ }^{90}$ Glauber Rocha, “Makunayma - 2", Folha de S. Paulo, São Paulo (SP), 28 out. 1978, p. 40.
} 
Do mesmo modo que esse seu intento procurava definir e destacar a marca de inovação do grupo cinema-novista - um grupo quase de heróis míticos sob sua concepção -, não se deve esquecer que, em igual disposição, embora um tanto velada, sua tentativa considerava ainda a necessidade de evitar a abordagem de eventuais desajustes e mesmo alianças mais conservadoras que, porventura, pudessem ter eles se beneficiados dentro da dinâmica do funcionamento do campo cinematográfico em expansão no Brasil dos anos 1960 e 1970.

Em todos os sentidos, por esta e outras razões, que José de Alencar se tornava personagem modelar. Se não o patrono das nossas letras, já ganhava, por parte de Glauber, algum fôlego para se tornar o patrono do nosso cinema. Sendo ele um homem de um tempo que sequer o cinema existia, e vindo de quem veio, tal feito não é pouca coisa. Cheio de cousas e lousas, o feito revelava matéria digna para um bom conto de Machado. Embora Glauber fosse discordante de muitas ideias de Roberto Schwarz, uma talvez ele devesse concordar com o crítico: "de Iracema, alguma coisa veio até Macunaíma"

\section{A organização programática do livro Revolução do cinema novo: isolamento e tentativa de conciliação}

A fortuna crítica de Glauber Rocha já assinalou Revolução do cinema novo de sua autoria como um livro programático, na medida em que foi uma obra de registro das marcas das ações políticas do grupo, juntamente com suas intenções no campo cultural brasileiro. Publicado em 1981, não foi uma obra programática no sentido restrito: ou seja, tão-somente uma carta de intenções do que foi um movimento. Revolução encampa uma proposta pessoal. O percurso pessoal do próprio Glauber. Seccionado, nesta caminhada, também está o perfil conciliatório do seu autor, sua experiência bastante amarga, emaranhada de críticas suas e de seus opositores.

Trata-se, em outras palavras, de um livro feito por um intelectual como o balanço de uma vida intensa e produtiva. Um livro com sua marca biográfica em cada linha e entrelinha. Se a obra não representasse o "fim" de um percurso - já que estaria por vir o último dos capítulos -, era evidente dentro da proposta sua sinalização e registro dos limites

\footnotetext{
${ }^{91}$ Roberto Schwarz, Ao vencedor as batatas, 2000, pp. 38-39.
} 
deste percurso numa jornada iniciada nos anos 1950. Era livro de um tortuoso trajeto marcado pela memória - desde as primeiras empreitadas do jovem crítico até a consagração do intelectual dentro do seu campo de atuação. Obra que, segundo seu autor, vinha para desfazer a incompreensão de muitos, fosse aqui ou lá fora.

Em seu percurso de trajetória intelectual - longo, combativo e de relativo sucesso e consagração - Glauber deixou um rastro de seus gestos, sempre marcado por uma fala perturbadora, uma declaração desconcertante, um texto pontual criticando práticas que priorizavam a utilidade individual e não coletiva. Revolução, como já assinalou Ismail Xavier no prefácio à nova edição da obra, é a garantia de que estes gestos foram reagrupados, revistos, refeitos e realinhados para nova ação, enfim, são eles mais uma vez transformados em voz combativa do seu autor, mesmo que, naquele momento, uma voz já embargada pelos ressentimentos da dura década de 1970, principalmente em seu quarto final, quando se isolou de forma mais radical.

No mesmo prefácio, já aqui referido, o crítico Ismail Xavier registra um tópico que merece aqui ser descrito pela sua força sugestiva para se pensar o livro de Glauber:

\begin{abstract}
"Os anos de batalhas vividas em filmes de impacto e numa política de autor conduzida com tino admirável já haviam deixado claro que a escala de seus embates era mundial, no que Glauber, com seu pendor para traçar amplos esquemas e intervir em tudo, encontrava no terreno fértil para a montagem do drama cujo conflito central, nas páginas de Revolução do cinema novo, já não deriva do combate por um programa, mas do combate por uma memória"92.
\end{abstract}

Quando se olha o conjunto estrutural de Revolução, a pergunta, talvez, mais adequada a se fazer seja: que significado tem essa memória no livro?

Não se trata de uma pergunta fácil de responder. Na formulação de uma resposta ainda provisória, é possível dizer que o livro, todo ele, é atravessado por dois tipos de memória e que ambas guardam certas ligações para a comparação.

Em primeiro lugar, seu autor criou uma tática de organização da própria memória individual; revirou baús e pincelou os textos que melhor representassem um percurso crítico de seu empenho intelectual. Aquilo que era registro inacabado ganha novos contornos para o novo tempo. Linhas são reescritas, formuladas e reformuladas.

\footnotetext{
${ }^{92}$ Ismail Xavier, "Prefácio", em Glauber Rocha, Revolução do cinema novo, 2004, p. 18.
} 
Ainda em relação ao prefácio escrito para a nova edição de Revolução, Ismail Xavier, em dado que pode parecer irrelevante ao leitor desatento, indica o grau de intervenção de Glauber e a sua disposição em se trabalhar a palavra nos seus limites, num vaivém de releituras e refeituras do texto original. O crítico vai apontar que Glauber, logo após finalizar seu último filme, $A$ idade da terra, começa seu trabalho de organizar o livro, escrevendo os "recados aos contemporâneos", selecionando e reescrevendo o que estava escrito, constituindo uma ordem para aquelas páginas: "O seu impulso era o de intervir até o último momento, fazer revisões radicais na vigésima quinta hora, como nos filmes, onde praticava um obsessivo recomeçar a cada etapa, a filmagem desfazendo o roteiro e sendo desfeita pela montagem" ${ }^{\prime 23}$. Seu esforço esteve em marcar os contornos do ensaísta no retrato do próprio objeto representado, conforme as palavras de Ismail: "Reafirmava no livro, num registro sem dúvida mais confessional, um estilo de trabalho que desenhava, nos gestos de 'caneta na mão', a imagem daquilo que seus escritos haviam afirmado como um princípio estético a orientar suas obras, sempre tensionadas e cada vez mais livres na justaposição de fragmentos" 94 .

Ao encontro do que disse o crítico, Carlos Augusto Calil, que era o coordenador editorial quando da publicação da primeira edição de Revolução pela Alhambra / Embrafilme, esclarece fatos em torno dos bastidores do livro. Suas palavras são bastante precisas quanto às intervenções de Glauber no processo de edição do livro:

\footnotetext{
"Pressionado pela data da viagem [a Veneza], Glauber alterava sucessivamente o conjunto, a montagem. De simples coletânea de textos prévios, passou a um ajuste de contas com o movimento do cinema novo e seus desdobramentos. Um nervoso balanço de geração. Uma autobiografia oblíqua. O encerramento de um capítulo da sua vida e da própria cultura brasileira. O processo era na verdade conduzido por uma determinação: a de recuperar o papel central na condução da política do cinema brasileiro" ${ }^{\prime 2}$.
}

Em outras palavras, o livro de Glauber é um passo firme em direção à sua própria memória. Aquilo que é registro acabado e representa o mesmo gesto do passado é trazido à tona para que se possa atualizar nas páginas impressas do livro. Aquilo que faltou, mas que

\footnotetext{
${ }^{93}$ Ismail Xavier, "Prefácio”, em Revolução do cinema novo, 2004, p. 13.

${ }^{94}$ Ismail Xavier, "Prefácio”, em Revolução do cinema novo, 2004, p. 13.

${ }^{95}$ Carlos Augusto Calil, "Glauber dá sua risada”, em Revolução do cinema novo, 2004, pp. 524-525.
} 
ainda a memória individual guarda como gesto necessário para ser lembrado nas novas circunstâncias, é costurado e urdido pela imaginação do seu autor. Nesses aspectos repousa esse primeiro tipo de memória.

A ela, adere-se a memória mais coletiva e participativa do que representou o próprio Cinema Novo. Glauber permite que ela, um arranjo de memória coletiva, circule entre seus textos, formule-se em discurso de uma história feita por seus próprios participantes, cujo personagem mais importante, talvez, fosse o próprio autor. Não é à toa que, como mais uma marca do seu gesto coletivo, ele escreva na parte final do livro os últimos retoques dessa história e insira no meio, como título de cada seção dedicada a essa história, os seus homenageados, aqueles que fizeram sua propalada "Heuztorya", mesmo que se dividissem, segundo ele, entre revolucionários e conservadores. É nítida nesse tipo de registro a marca atualizada de um tempo, como também ficam nítidos seus afetos e desavenças, resultado da simbiose entre aquilo que se forjou como individual e como coletivo.

Da sua memória individual que se entrelaça à coletiva sobressai um confronto ponderado por duas intenções suas: a tentativa de conciliação com membros de seu antigo grupo e a tentativa de marcar pelo passado uma história coletiva como exemplo para o futuro, esperança de que pudesse ser reavivada por todos aqueles que dela participaram.

A ideia de se fazer um livro que, de forma ou de outra, pudesse continuar a "linha de combate" de Revisão crítica era uma aposta antiga de Glauber. Aos 32 anos, portanto no início dos anos 1970, ele resolve fazer um depoimento gravado em fita cassete, de onde se transcreveu o seguinte trecho atestando sua intenção:

"Eu resolvi escrever esse livro porque achei que tinha chegado a hora de dar um balanço acadêmico, de década. 'Década de 60, vamos fazer um balanço'. Não, não é isso. Por uma coincidência, os anos 60 foram os anos mais importantes do Cinema Brasileiro.

[...] Eu resolvi gravar este livro, porque eu não queria me sentar numa máquina, porque em me sentando numa máquina, eu ia tomar uma posição típica da maioria dos críticos e dos intelectuais brasileiros de dizer: 'Está tudo uma porcaria, eu sei de tudo, vocês não sabem de nada'. Então, eu começaria a citar livros, fontes bibliográficas, defender uma posição culturalista, uma posição historicista, uma posição estruturalista e conceituar sobre o vago. Não o cinema brasileiro é a minha carne. 
Eu quero, então, fazer o seguinte: não quero falar do que existia antes de 1960, porque, como eu estava dizendo, está lá em Revisão crítica do cinema brasileiro, pra quem quiser ver. Eu quero falar a partir... Eu quero começar a refazer o VI capítulo do meu livro - Origens de um Novo Cinema. E pra refazer esse VI capítulo até hoje, eu quero contar, eu peço então desculpas ao leitor ou a quem esteja ainda interessado em cinema brasileiro, por uma certa indisciplina que vai haver esse livro, por uma certa falta de erudição que tanto glorifica certos críticos que são especialistas em cinema estrangeiro e analfabetos em cinema nacional $[\ldots]^{p 96}$.

A ideia de passar em revista o cinema a partir de 1960, embora iniciada bem antes, como se pôde notar, só ganhou corpo anos depois. Distinta da proposta inicial, onde o livro integralmente se anunciava como a continuidade dos capítulos finais de Revisão crítica, Glauber faz de Revolução um livro de conjunturas e desabafo de momento. Uma conjuntura pessoal e histórica, por assim dizer, reavivando a matéria da memória nas suas dimensões mais íntima e autobiográfica e a matéria coletiva, tentativa conciliatória de recolocar o grupo e o movimento do Cinema Novo nos trilhos de uma nova marcha histórica.

Daqueles anos finais de década, em um ambiente acalorado como foi o da produção de Revolução, eu chamo a atenção para duas ocorrências: uma no Festival de Brasília e outra por uma reação em torno do lançamento brasileiro de $A$ idade da terra, seu último filme. Estas duas ações revelam e documentam a dimensão do momento vivido por Glauber.

Em setembro de 1979, sem que tivesse um filme seu inscrito no certame, Glauber chega ao Festival de Brasília disposto a fazer um escândalo. Segue para o Hotel Nacional, onde ele sabia que júri, convidados, organizadores e autoridades do evento se hospedavam. No saguão do hotel, começa esbravejar diante de todos. Jean Rouch, cineasta francês e um dos convidados do Festival, é acusado por Glauber de espião dos países desenvolvidos. Além de espião, Pierre Kast, também francês e outro convidado do evento, é tachado de participar do "bando da cinemateca francesa". Ruy Pereira da Silva, então presidente da Fundação Cultural do Distrito Federal, responsável pela organização do evento, é acusado de "agente da CIA que no Festival do ano passado bancou o dedo-duro, entregando diretores nacionais às autoridades".

\footnotetext{
${ }^{96}$ Glauber Rocha, “Transcrição de depoimento de fita cassete”, 1970-1971? [Datiloscrito, 18 páginas, inédito, Centro de Documentação e Pesquisa da Cinemateca Brasileira, São Paulo (SP)].
} 
Já quase sendo encaminhado para fora do hotel por seguranças, Glauber continuava suas acusações. Dizia em alto e bom som: primeiro, "o Brasil de Figueiredo não aceita a presença de espiões”, para em seguida solicitar da plateia, já presente em bom número, que todos, dentro do Festival, se manifestassem em favor da exigência da demissão do seu diretor. As frases de efeito ditavam o tom final do seu discurso no saguão do hotel: "este é um festival infiltrado de agentes estrangeiros"; trata-se, dizia, de "uma mostra onde só existem cineastas prostituídos pelo dinheiro da Embrafilme" ${ }^{\text {97 }}$. Já fora do saguão e na porta de entrada do hotel reúne jornalistas para mais um discurso. Glauber ensaiava uma prévia do que faria, um ano depois, em Veneza, em meio a um dos mais famosos festivais do velho mundo.

Em novembro de 1980, dois meses depois do escândalo de Veneza, Glauber tem à sua frente um novo desafio. O lançamento nas capitais paulista e carioca de seu último filme, $A$ idade da terra. Uma ocasião, como avaliou, adequada para que escrevesse o seu texto "Idade da Terra: um aviso aos intelectuais", publicado na Folha de S. Paulo, em 9 de novembro de 1980.

Antes de ser notado como um comum artigo de jornal, tal texto deve ser compreendido como um recado de seu combate. Um retrato da situação incômoda que Glauber já estava experimentando quase que no mesmo momento de finalização de Revolução. Trata-se, enfim, de um texto que diz muito sobre o modo como ele estava sendo visto por seus críticos e sobre a forma como ele solicita as regras do jogo e das críticas em torno de $A$ idade da terra. Assim, escreve: “Antes da 'batalha', quero solicitar, sobretudo aos yntelektuais que serão implacáveis, condições para que o combate se desenrole democraticamente, alimentando mesmo com vômitos e diarréias o fértil deserto de nossas 'aberturas fygueyrediztas'”98.

Que condições e regulamento Glauber quer estipular para o procedimento crítico de seus adversários?

Antes de qualquer coisa, que tais adversários não confundam sua pessoa com o que seu filme pudesse gerar em termos de recepção. É preciso lembrar que Glauber vinha da experiência um tanto traumática da nada boa recepção do filme em Veneza. É desse modo

\footnotetext{
${ }^{97}$ Cf. Orlando L. Fassoni, "Glauber, um escândalo no Festival", Folha de S. Paulo, São Paulo (SP), 26 set. 1979, p. 31.

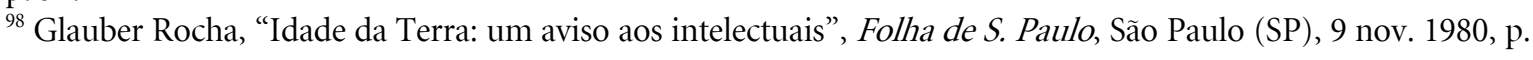
51.
} 
que ele lamenta que $A$ idade da terra não possa prescindir da mitologia que a ele estava atribuída. Tal trecho é bastante ilustrativo deste seu ponto de vista:

\begin{abstract}
"Espero que o filme seja criticado pelos intelectuais com o mínimo de preconceitos que existem em torno, sub e sobre 'Glauber Rocha'. São legendas alimentadas por Deus e pelo Diabo que proclamam aos 4 ventos minhas virtudes e males. Aos 41 anos me vejo mytyfykado - o que é tragypoetyko - porque o myto sofre do mal de ser odiado ou amado não pelo cerne vital (ou medula sexual) mas pelas várias e diferentes versões que a sociedade constrói e divulga a seu respeito. Lamento que apenas uma centena de yntelektuais brasileiros tenham consciência da importância revolucionária de minha obrakynomatographyka.

A imprensa, via artigos de jornalistas teleguiados, procura me pintar como louko, marginal, fracassado, corrupto fascista e todos estes adjetivos tentam esconder a criatividade de meus filmes. A minoria de jornalistas que revela a realidade sobre Glauber Rocha é acusada de escrever sob pressão dos 'meus ferrões', expressão usada por meu dileto Alberto Dines em 'Pasquim' [...]"'99.
\end{abstract}

Essas duas ações, o discurso ácido promovido em pleno Festival de Brasília e o recado dirigido aos seus críticos, demonstram com clareza, da parte de Glauber, a atmosfera de isolamento que ele estava submetido. Conforme o crítico Ismail Xavier havia notado, o cineasta vivia um tempo de descompasso com a cultura e o mundo do cinema, cujas marcas seriam gritantes no enredo de Revolução do cinema novo: "era um tempo adverso em que ele não encontrava os sinais desejados, nem as interpretações desejadas, num ambiente de produção e de crítica que, a seu ver, estava conformado com os caminhos de um cinema que se racionalizava em nome de imperativos comerciais" ${ }^{\prime 100}$.

Entrevistas suas desde a época do lançamento de seu único livro publicado de ficção, Riverão Sussuarana, em 1978, dão conta também de um estágio deste isolamento vivido por ele. Afirmara sobre a falta de um diálogo existente entre ele e o que julgou ser "os donos oficiais da cultura", que, segundo o cineasta, não o perdoavam por conta de sua independência em relação à tradicional esquerda brasileira ${ }^{101}$. Custava-lhe, assim, a repressão por todos os lados, inclusive em meios editoriais. O cineasta baiano partia de uma hipótese

\footnotetext{
${ }^{99}$ Glauber Rocha, "Idade da Terra: um aviso aos intelectuais", Folha de S. Paulo, São Paulo (SP), 9 nov. 1980, p. 51.

${ }^{100}$ Ismail Xavier, "Prefácio”, em Revolução do cinema novo, 2004, p. 15.

${ }^{101}$ Cf. Glauber Rocha em Isa Cambará, "'Contra dos donos oficiais da cultura”, Folha de S. Paulo, São Paulo (SP), 30 maio 1978, p. 37. [Depoimento].
} 
para o isolamento: os intelectuais não queriam responder sua forma ousada e provocativa de discurso. Sem respostas, Glauber não encontrou outro caminho possível que não o isolamento, além das tentativas seguidas, mas pouco satisfatórias, de conciliação e reagrupamento com intelectuais que surgiram com o Cinema Novo.

Um dado trazido por Carlos Augusto Calil sobre os bastidores de edição de Revolução revela o quão forte se projetava em Glauber o desejo de conciliação, embora desejo vindo de um isolamento pessoal dentro do mundo intelectual. Nas palavras do crítico lê-se o seguinte:

"A prova dos nove está na fotografia escolhida para a capa de Revolução do cinema novo. Até o momento de seguir para a gráfica, a capa deveria apresentar um desenho primitivo / simbolista de Paula Gaitán, a mulher do autor. No derradeiro instante, Glauber sacou do baú a fotografia em que divide a cena com Nelson Pereira dos Santos, o verdadeiro guru do cinema novo, o montador que havia dado forma aos impulsos contraditórios de Barravento. E que havia avalizado o ingresso de Glauber Rocha no cinema"102.

O sentido trazido pela escolha da foto (figura 3) pelo cineasta baiano é múltiplo. Primeiro, deve-se destacar que a sugestão da imagem, ancorada no riso cheio de espertezas e marotagem de Nelson e Glauber, remete, como o autor previra, ao tempo de origem do Cinema Novo. Tratava-se, conforme afirmou Calil, de uma época "em que ocupavam a mesma trincheira" ${ }^{103}$. Embora fosse uma imagem de 1974, em Cannes, a memória levantada por ela ultrapassa em longe tal tempo. A força da imagem, com Nelson e Glauber lado a lado, registra uma cumplicidade vinda do tempo retratado no próprio livro. Estrategicamente, na memória, tanto coletiva como individual, evocada pela foto, pela capa, Glauber começa sua história recheada de balanços e opiniões. Na sua concepção, já que se tratava de um livro que também desembocava no seu isolamento e seus ressentimentos, parecia uma escolha justa para seu leitor de Revolução que ele pudesse fazer seu primeiro juízo a partir daquele símbolo. Mesmo o leitor mais desavisado, faria suas implicações diante de Glauber e Nelson sorridentes.

\footnotetext{
${ }^{102}$ Carlos Augusto Calil, "Glauber dá sua risada”, em Revolução do cinema novo, 2004, p. 525.

${ }^{103}$ Carlos Augusto Calil, "Glauber dá sua risada”, em Revolução do cinema novo, 2004, p. 525.
} 


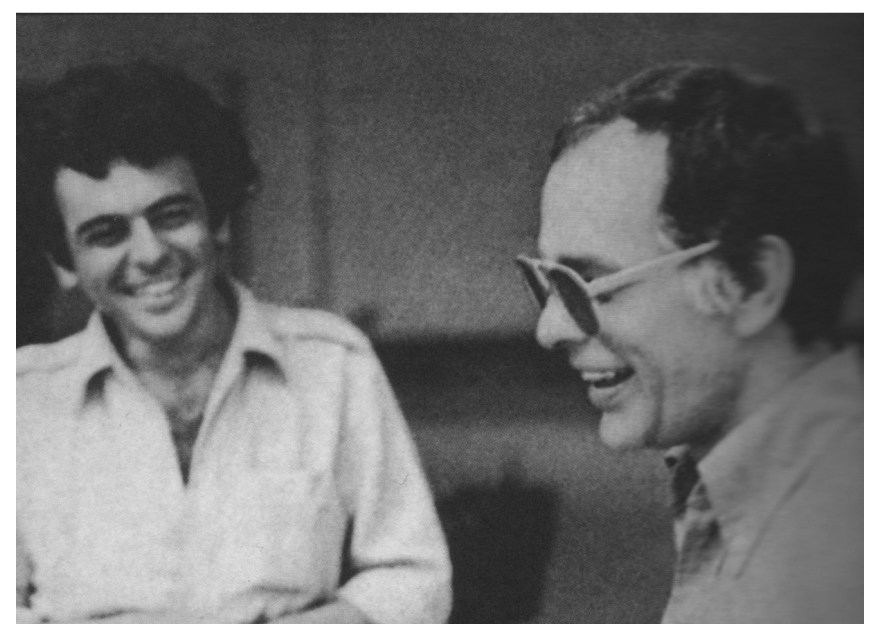

Figura 3. Glauber Rocha e Nelson Pereira dos Santos, em Cannes, no ano de 1974.

Foto da capa da primeira edição de Revolução do cinema novo (1981).

\section{Prefácios, Américas e outras trajetórias}

Para o momento, cabe salientar mais de perto todos esses fatores presentes na escrita de Revolução do cinema novo. Uma escrita que vai acomodar todos estes problemas pessoais. Um livro de memórias, tanto de seu autor, como de sua disposição em termos coletivos, de avaliar pessoas e fatos. Vejamos.

As nomeações em torno de Revolução são muitas. Tantas quanto o mito do seu autor poderia comportar. Já se disse do livro que era "meio bíblico" (David Neves) como um testamento do nosso cinema, que retratava o "delírio de um grande artista visionário" (Cacá Diegues), que tratava de "uma autobiografia oblíqua" (Carlos Augusto Calil), que foi também composto, entre outras coisas, de um "autorretrato do artista como a figura do injustiçado" (Ismail Xavier). Acrescentaria a essas definições, espécie de complemento a todas às outras, que Revolução foi acima de tudo um livro de reação. Antes que se questione "reação a quê?", digo que Glauber, como veremos em seus dois prefácios, parte para a defesa de sua posição consagrada dentro do campo cinematográfico, reagindo contra aqueles que buscavam desestabilizar aquilo que ele considerava uma ordem estabelecida pelo Cinema Novo de tempos atrás. Dentro da perspectiva do cineasta baiano, está sua estratégia em revalidar o modelo de avaliação de filmes pelo parâmetro criado nos tempos do movimento cinemanovista. Ele sabia quem eram seus adversários de momento. Tendo em vista tal situação, hoje seria possível dizer: um espectro rondava Glauber e aqueles que porventura estivessem ao seu lado - o espectro da irrupção de novos críticos. Todos se uniam numa Santa Aliança para 
conjurá-lo, Glauber: os críticos de esquerda, a nova leva de cineastas e a velha leva de cineastas discordantes, sem contar críticos de uma direita conservadora.

Dito isso, comento a seguir os prefácios dedicados à obra. Disse prefácios, pois Glauber formalizou dois deles. Apenas um, o mais sintético deles, foi publicado, em 1981. O outro, inédito até a reedição da obra, em 2004, oferece uma boa base de comparação para a leitura daquele que foi publicado na primeira edição.

Tanto o prefácio publicado em Revolução, intitulado "Prefácio de uma Revolução", como o não publicado na edição de 1981, este sob o nome "Prefácio 80", são unânimes em registrar a crise de memória vivida em torno do movimento e do grupo do Cinema Novo. No primeiro prefácio, nas suas linhas iniciais, parece-me que o seu autor não se esforça para construir tão-somente um estudo histórico do movimento. Logo se vê que por detrás desta intenção paira outra: demonstrar suas razões pessoais em torno do que constituiu e formou-se ao redor do grupo e, com ele, sua posterior dissolução. Tal encontro não é nada pacífico em Glauber. Significa, em suas palavras, que uma geração de intelectuais fora "dilacerada pelo cruel processo nacyonal" ${ }^{104}$. Sem alternativas, ele buscaria analisar esse processo.

Neste prefácio publicado, o tom de Glauber é trágico. Traz, à reboque disso, o sentido de um alerta geral para um fim iminente: "Sofre o cinema novo uma guerra interna e externa que ameaça destruí-lo desde suas origens até hoje" ${ }^{105}$. Ele não hesita e sua opção pelo tom de um manifesto trágico talvez explique uma outra razão, não menos importante. Ao invés de publicar o texto bastante explicativo e longo, que é o "Prefácio 80", Glauber preferiu uma versão mais sintética, mais enxuta, que inevitavelmente, em face de sua escrita mais sintomática da sua experiência contemporânea, despendia uma leitura mais pessimista do retrato por ele composto e divulgado. Um retrato, por sinal, que também remeteria a sua própria biografia, feita naquele momento de isolamento e ressentimento geral.

Dentro do intercâmbio existente entre os dois textos, é curioso ainda notar ideias que aparecem em "Prefácio 80" e que foram suprimidas na versão publicada de "Prefácio de uma Revolução". No texto inédito à primeira edição, há uma nítida diferença para a abordagem de seu ressentimento e sua esperança de reconciliação com os ex-integrantes do Cinema Novo, sua clara tentativa ou marca de um sentimento de que seria bastante possível,

\footnotetext{
${ }^{104}$ Glauber Rocha, "Prefácio de uma Revolução", em Revolução do cinema novo, 2004, p. 35.

${ }^{105}$ Glauber Rocha, "Prefácio de uma Revolução", em Revolução do cinema novo, 2004, p. 35.
} 
e até certo ponto provável, evitar-se a dissolução do grupo por completo. Note-se o seguinte trecho de "Prefácio 80", cujo tom é menos abalado e pessimista que o presente na versão publicada no livro de primeira edição:

"Hoje os Irmãos do Cinema Novo estão desunidos, alguns brigados, outros desesperados, poucos não se deixaram dominar pela guerra egocêntrica, mas autofagicamente reconstruindo o espaço Kinomatografico num Brazyl précolonizado pelo cinema novo.

Vivo, matado várias vezes, sempre ressuscitado desde que necessário, o cinema novo permanece dominando o Cinema Brasileiro.

Em qualquer grupo cinematográfico, dos muitos filhos e netos e bisnetos do cinema novo, existe a Teologia Cinemanovista jamais destruída por quantas intentonas revisionistas. Tentaram, durante todo o subvertido per-dis-re-curso do rio cinemanovista, sabotar o Movimento.

O Movimento superou os reacionários anticinemanovistas sustentado pelos intelectuais colonizados ainda ignorantes da cultural audiovisual" ${ }^{106}$.

Dado o trecho anterior, a primeira observação a ser feita refere-se à forma como Glauber vai tratar seus antigos colegas de Cinema Novo. O substantivo “Irmãos”, utilizado com iniciais maiúsculas, tendo ele aparecido em mais de uma vez neste texto, já é por si só digno para significar um convite conciliatório a todos. O cineasta baiano faz sua chamada para propor uma nova dinâmica de ação para os colegas do ex-grupo: "O cinema novo, pela boca de qualquer dos Irmãos, ou da minha poderá criticar seus críticos - não para puni-los como indivíduos mas para educá-los e dialeticamente re-educar ou iniciar alguns Irmãos desviados mas, como salienta Joaquim Pedro de Andrade, nunca prostituídos”107. Embora constate a desunião do grupo naquele momento, ele supõe uma carga de vivacidade e de importância tão significativa ao movimento de modo que impediria, mesmo os mais descrentes, qualquer reação contrária ao que significou e, segundo Glauber, ainda significava o projeto histórico do Cinema Novo. Há de se prever que é por este motivo que ele cria um quadro histórico da nossa cultura, inserindo seu movimento de cinema em vitrine privilegiada:

\footnotetext{
${ }^{106}$ Glauber Rocha, "Prefácio 80”, em Revolução do cinema novo, 2004, pp. 515-516.

${ }^{107}$ Glauber Rocha, “Prefácio 80”, em Revolução do cinema novo, 2004, p. 516.
} 
"Do barroco satírico-místico-lírico de Gregório de Mattos, da épica geocósmica do Padre António Vieira, da inconfidência árcade, do romantismo abolicionista e republicano, do positivismo neocapitalista. Ciclo iniciante do cinema novo - o 1922 da Semana de Arte Moderna, do levante Tenentista no Forte de Copacabana e da Fundação do Partido Comunista - a Utopya se metaforiza na barroca linguagem simbólica do nosso tropicalismo se expressando à medida que estrutura o inconsciente coletivo poetykas máximas de o Aleijadinho \& VillaLobos, plástica e som do Korpo Brazyl, KORPOBRAZ"108.

Uma tanto distinta parece ser a chamada conciliatória, se assim podemos chamála, formulada por Glauber em "Prefácio de uma Revolução”. Se comparada ao prefácio inédito à primeira edição, esta se encontra suavizada por outros fatores. O recado aos exintegrantes contido no prefácio publicado é oferecido de forma indireta. Consciente do que acontecera, Glauber tenta mostrar que aquilo que o grupo havia acolhido de diferenças de seus artistas, razão pela qual este mesmo grupo tornou-se dominante no campo cinematográfico, foi também aquilo que levou o grupo à crise, cujo saldo final levou-os à dissolução daquilo que os ligava.

Neste sentido, aquelas "mil faces do cinema novo"109 vinham desorientar não só os críticos nacionais, como Glauber escreveu, mas também vinham demonstrar que dentro do grupo não só havia "revolucionários" como também "conservadores". Ao invés do apelo direto para a luta, tal como o contido em "Prefácio 80", a solicitação do cineasta aos exintegrantes gira em torno da demonstração do seu próprio exemplo em escrever um grande livro, revirando as memórias do Cinema Novo. Nas entrelinhas havia uma sugestão que todos devessem seguir. Só desse modo, dentro da perspectiva de Glauber, seria possível engrossar o coro em nome de uma memória coletiva do movimento. Ele deixava, assim, seu recado final: a existência de todos, em termos intelectuais, só viria a se concretizar, de fato, na medida em que todos participassem de modo a reescrever a história do Cinema Novo como uma história distinta e distintiva das demais no campo cinematográfico, no qual todos participavam. Diz ele: "Quase todos os cineastas do movimento escreverão suas memórias que serão tão diferentes na miséria e na grandeza quanto seus filmes construtores audiovisuais do Payz do

\footnotetext{
${ }^{108}$ Glauber Rocha, "Prefácio 80”, em Revolução do cinema novo, 2004, p. 518.

${ }^{109}$ Glauber Rocha, "Prefácio de uma Revolução", em Revolução do cinema novo, 2004, p. 35.
} 
Futuro no desejo do suicida Stefan Zweig. O livro é também a revisão crítica do crítico que sou há 25 anos"110.

Dos prefácios para o miolo central do livro. Se em parte considerável de páginas de Revolução tem-se um livro montado por Glauber a partir de textos antes publicados em jornais e revistas, devem-se considerar, em sua estratégia, também os textos inéditos que entraram nesta montagem. Exemplo disso é “América Nuestra 69". Neste caso, trata-se de um texto em que Glauber faz uma reflexão a partir do seu projeto de roteiro de América Nuestra - um filme pensado por ele ainda nos anos 1960 e que abarcou vários tratamentos de roteiros e várias propostas de filmagem ensaiadas em várias circunstâncias e conjunturas em âmbito nacional e estrangeiro; trata-se ainda de uma reflexão que ofereceu subsídio importante para outros projetos fílmicos do autor, tais como Terra em transe, Cabezas cortadas e A idade da terra.

Na dinâmica organizada por Glauber dentro de Revolução, "América Nuestra 69" tem papel estratégico. Pode ser considerado como um ensaio que chama a atenção para o drama vivido pelo intelectual em uma situação de subdesenvolvimento, fosse ele de cinema ou não. Glauber é o exemplo deste intelectual; um sujeito que quer deixar à vista de todos sua ambição nada menor, por isso impõe-se a revelar o teatro, e a teatralidade, de seu projeto audacioso.

Sobre Revolução, Ismail Xavier, em seu já aqui referido prefácio, notou muito bem a identidade de homem prático ("múltiplo homem brasileiro") de Glauber presente na obra. Sob o domínio do cinema, arte em que a viabilização econômica interfere como elemento externo à sua exigência interna, Glauber, verdadeiro "múltiplo homem brasileiro", soube como nenhum outro encharcar-se dessa situação para revertê-la em nome próprio, transformando essa relação em bandeira de luta na condição de periferia. Ainda sobre a ótica do prefácio de Ismail, é bastante apropriado o que o crítico observa, podendo tal conteúdo ser expandido para o caso específico de "América Nuestra 69": "A insistência de Glauber nesta multiplicidade de empenhos define o teor de sua prática diária que se orienta por uma concepção da cultura em que os gestos pessoais se fazem representações de forças maiores enlaçadas na conformação de destinos coletivos" ${ }^{\prime 11}$.

\footnotetext{
${ }^{110}$ Glauber Rocha, "Prefácio de uma Revolução", em Revolução do cinema novo, 2004, p. 36.

${ }^{111}$ Ismail Xavier, "Prefácio", em Revolução do cinema novo, 2004, p. 20.
} 
É bem possível e não é nenhum exagero supor que a escolha de "América Nuestra 69" sirva para não só demarcar um momento de grande síntese de lembranças individuais de uma luta, por assim dizer, coletiva, extraída (tal memória) de uma época de grande consagração alcançada por Glauber, como também seja a notação de um recado para os descrentes na história do Cinema Novo, além de ser uma explicação para si mesmo das razões de sucessos e insucessos que marcaram sua trajetória intelectual.

O início do ensaio diz muito sobre esse projeto ambicioso: "Poema Épico, Representação Teatral, comentário, polêmica e política da América Latina"112. E seu tom de diário exemplifica com exatidão a ambição intelectual por ele trilhada. Seu objetivo era mostrar, na base do instantâneo fotográfico de uma época e de certas circunstâncias pessoais, que se tratava de um projeto que ultrapassava as fronteiras nacionais, ao passo que, paradoxalmente, também firmava seu compromisso em discutir o elemento nacional de forma coletiva.

Na tonalidade de diário presente em “America Nuestra 69", Glauber encontra espaço para a demonstração do afeto aos seus companheiros, demonstrando que o retrato congelado de suas relações pessoais também era o registro de uma vida intelectual de uma criação coletiva, cujo projeto de filmagem de América Nuestra poderia ser a síntese de todo aquele movimento de um tempo perdido:

“[...] Conversar com Leon desenvolve minha razão cinematográfica. Nelson me põe em dúvida. Walter me dá segurança. Cacá me aprimora a cultura. Gustavo educa meu gosto. Paulo César ajuda minha integridade. Zelito me estimula. Barreto. David é meu confidente. Antônio e Escorel são meus colaboradores, ... que eles devem fazer filmes e penso em produzir os primeiros filmes deles. Conversar com Gianni Amico é fantástico. Gianni e... não existem. Gianni vai me ajudar a botar os planos do Leão. Trigueirinho e Gianni me ensinaram tanto do cinema como... e... do teatro e da arte em geral. Na crítica, Walter da Silveira me introduziu. Paulo Emílio, Alex, o Presidente, Rudá, Louis Marcorelles e até mesmo me ensinaram muito. Inclusive o Salvyano!!!

Falo daqui destas coisas porque quero talvez me livrar de todas as influências boas e ruins para me preparar para filmar.

[...] Penso nos mortos anônimos e famosos pela libertação da América Latina. Temo que não possa fazer este filme, mas pelo menos vou escrevê-lo.

\footnotetext{
${ }^{112}$ Glauber Rocha, “América Nuestra 69”, em Revolução do cinema novo, 2004, p. 161.
} 
As várias versões ficarão guardadas na medida do possível, o que poderá permitir uma análise mais profunda de todo o filme"113.

Ainda em relação à “América Nuestra 69", há outros trechos que se prestam ao registro de uma situação que Glauber faz supor ser enfrentada por todos os participantes cinema-novistas. Escreve ele em certo momento do texto: "Os autores que criaram grandes obras na América Latina venceram o medo de não sucumbir ao terrorismo do complexo de inferioridade" 114 . Ele compartilha o sentimento de que, como intelectual periférico, é preciso encarar o centro (entendam-se países desenvolvidos) com ousadia e pretensão além das próprias fronteiras. Um valor que justificava o empenho alcançado pelo Cinema Novo. Como disse: "virou um fenômeno cultural internacional"115. Por esta perspectiva, razão pela qual o movimento cinema-novista despertava ataques de todos os cantos: o Cinema Novo havia, afinal, ainda segundo Glauber, atingido o complexo de inferioridade de modo tão violento que reações poderiam ser consideradas normais àquela altura. Não restava dúvida para o cineasta, os cinema-novistas tinham implementado o "capítulo 2" da Semana de Arte Moderna.

Integrado a essa forma de revalorização dos feitos e ações de intelectuais ligados ao Cinema Novo, está outra discussão presente em Revolução. Esta indica uma motivação conciliatória de seu autor no jogo de construção histórica ali implementado. Refiro-me à parte final do livro. Nela, Glauber constitui um mosaico de trajetórias com um duplo propósito: 1) valorizar os principais exemplos do Cinema Novo por meio de seus participantes; 2) reafirmar uma história totalizadora do nosso cinema, integrando-o definitivamente ao ramo da alta cultura nacional. Tomando de empréstimo a expressão de Ismail Xavier, vou dizer que Glauber fez questão de escrever a história cultural desse "múltiplo homem brasileiro" pelos protagonistas, coadjuvantes e eventuais discordantes que também tratou.

Tais trajetórias escritas por Glauber ocupam uma parte significativa de páginas de Revolução. Aproximadamente, um pouco mais de um quinto do livro. Embora o dado quantitativo, neste caso, não queira dizer muita coisa, é notável, mesmo assim, que nestas páginas ele tenha sumarizado uma grande quantidade de produtores culturais, atores,

\footnotetext{
${ }^{113}$ Glauber Rocha, “América Nuestra 69”, em Revolução do cinema novo, 2004, p. 163.

${ }^{114}$ Glauber Rocha, “América Nuestra 69”, em Revolução do cinema novo, 2004, p. 164.

${ }^{115}$ Glauber Rocha, “América Nuestra 69”, em Revolução do cinema novo, 2004, p. 166.
} 
cineastas etc. Mas a questão se mostra mais intrigante, entretanto, se levarmos em conta a forma como cada um ou parcela destes personagens inseriu-se no texto do cineasta baiano.

As passagens que Glauber escolhe para inserir seus personagens não são aleatórias. O uso consciente dessas passagens pode ser mais bem visualizado quando a escolha está diretamente ligada aos seus adversários dentro do campo cinematográfico. Exemplo dos cineastas Júlio Bressane e Rogério Sganzerla. Para o primeiro, ele se refere à "luta contra agentes externos e internos personificados: [...] no udigrudi concretotropicanalhista" ${ }^{116}$; para o segundo, o recado segue: "precisamos acabar com esta mania de importar filósofos euramericanos e viver de citações anticriativas" ${ }^{\prime 17}$.

É o caso de se notar ainda mais seu método. Acompanhe-se a figura a seguir; uma página manuscrita de um trecho em que Glauber faz reparos e acréscimos na escrita desses fragmentos biográficos:

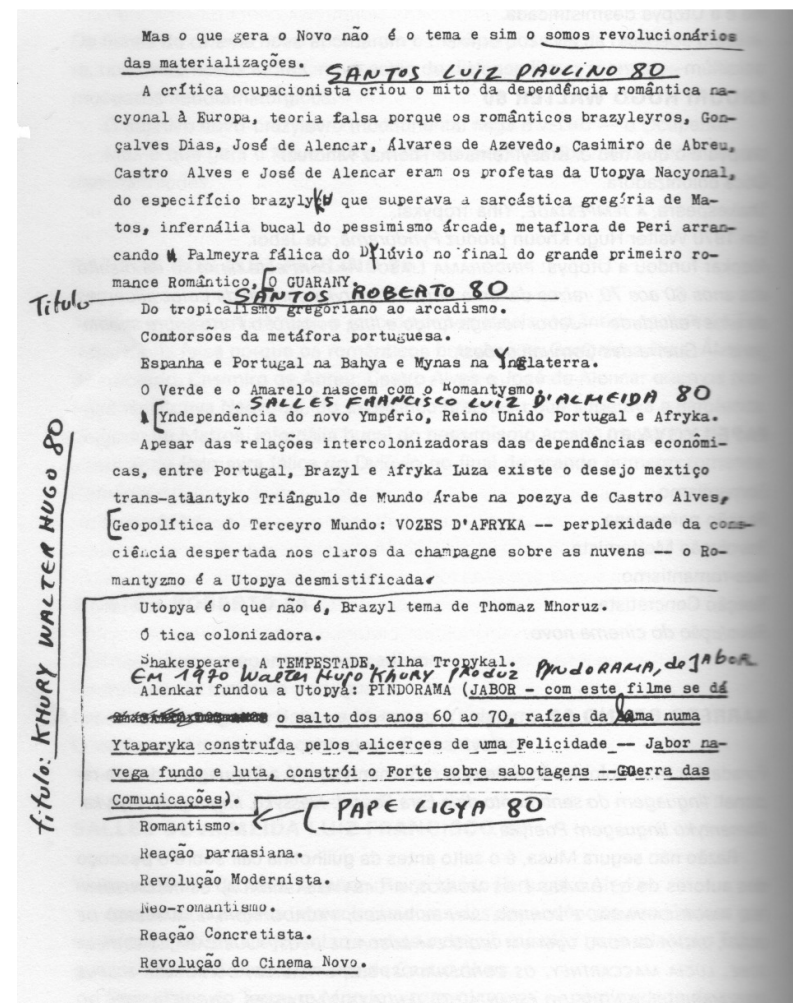

Figura 4. Página datiloscrita para o preparo da primeira edição de Revolução do Cinema Novo. Emendas de Glauber Rocha. Extraído da edição de Revolução, publicada pela Cosac Naify.

\footnotetext{
${ }^{116}$ Glauber Rocha, “Bressane Júlio 80”, em Revolução do cinema novo, 2004, p. 467.

117 Glauber Rocha, “Sganzerla Rogério 80”, em Revolução do cinema novo, 2004, p. 487.
} 


\section{O que deste exemplo extrair?}

Primeira questão a se notar são os intertítulos feitos no calor da revisão final. Provavelmente, conforme relatou Carlos Augusto Calil e Ismail Xavier, às vésperas do embarque para Veneza, onde apresentaria ao mundo o seu $A$ idade da terra. A letra de forma, puxada por setas, cortes no texto e grifos, é a marca mais evidente de que todas aquelas emendas projetavam uma decisão de última hora no que já se considerava o texto editado e final para a composição das páginas de Revolução. Uma marca que, sob certos aspectos, lembra o método de outras composições suas; para não se alongar, fico em dois exemplos: é a história de Corisco, num primeiro tratamento de seu argumento $A$ ira de Deus, que vai se transformando por enxertos até se chegar à versão utilizada, em forma de roteiro, nas filmagens de Deus e o Diabo na terra do sol; são os poemas compostos para Paulo Martins, de Terra em transe, que ensejam uma linha de interpretação possível para a história pessoal e ressentida do personagem, que vai, depois, na composição final do filme e no seu roteiro final, ganhando outros elementos, outras falas, até se chegar ao produto final que conhecemos, em que os poemas são um entre vários elementos que nos leva a definir os traços daquele protagonista.

Salientem-se as implicações deste método neste exemplo extraído de Revolução. No que seria um texto único, Glauber o corta para sua montagem e acrescenta o nome das personalidades que acreditava serem as mais compatíveis com a escrita do seu ensaio. As personalidades-títulos são: Luiz Paulino dos Santos, Roberto Santos, Francisco Luiz de Almeida Salles, Walter Hugo Khoury e Lygia Pape. A mistura vai de cineasta baiano à artista neoconcreta, indicação de que seu método não criava um texto particular para cada nome remetido, mas sim impunha o fragmento do texto maior ao particular do que era o título e o personagem retratado. Em nível hierárquico de composição, seria possível dizer que não era o texto que se submetia ao biografado, mas o biografado que se submetia ao texto já delineado. O efeito é um resultado onde o leitor não consegue afirmar com precisão o momento de entrada do dado biográfico e o momento de interpretação histórica do autor.

Sob certo ângulo, sua prática é de uma nova montagem ao texto. Caso se note apenas o texto em seu conjunto, sem que se leve em conta os intertítulos, não há sombra de dúvida que Glauber está ensaiando um texto de interpretação do Brasil, que passa pelo nosso romantismo e mais uma vez seu ponto final é a revolução do Cinema Novo, tão pregada por ele. Glauber entrecorta a análise para posicionar personagens do mundo nacional, como se 
fossem peças de um tabuleiro. Para ele, não vale ressaltar a história individual destes homens e mulheres do cinema, mas sim submetê-los dentro de uma história coletiva.

Deste exemplo trazido cabe dizer:

Em relação ao cineasta baiano Luiz Paulino dos Santos, o mesmo que Glauber havia afastado das filmagens de Barravento no início dos anos 1960, o autor de Revolução inicia sua interpretação sobre a independência do nosso romantismo, confirmando o que já havia dito em suas polêmicas anteriores entre Machado e Alencar, este um dos "profetas da Utopya Nacyonal"118.

Quanto a Roberto Santos, cineasta que ele considerava a "velha bossa séria" do nosso cinema, seu texto faz uma síntese, cuja referência demarca a essência do romantismo verde-amarelo. Como se o cineasta de $O$ grande momento trouxesse consigo uma herança rica e nacional, desde os tempos de colônia.

Para o caso de Francisco Luiz de Almeida Salles, aquele que Glauber já havia apontado como seu candidato ao Ministério da Cultura ${ }^{119}$, seu texto segue a tendência de defesa de uma tese: agora o desejo de libertação colonial, simbolizado pelas "Vozes d'África" de Castro Alves, alcança sua utopia máxima - "o Romantyzmo é a Utopya desmistificada" 20.

Já em relação à Walter Hugo Khoury, a utopia continua como assunto organizador da vida nacional; são gestos que Glauber quer explicitar: sobretudo, que aquela utopia participativa de um novo cinema moderno brasileiro é a ramificação mais nobre do que se representou do melhor de nossa cultura no tempo passado. Nesse horizonte de interpretações, a utopia é encarada por Glauber em um sentido mais amplo do que se possa imaginar. Existem textos inéditos de Glauber em torno exclusivamente deste tema: caso de "Methaphora da Utopya 80", que fora utilizado por ele em Revolução; ou textos como "Revolução do Brazyl”, em que ele escreveu “[...] a Companhia das Índias deseja criar uma Utopya" 121 ; ou em interpretações da nossa vida literária, como no texto "Revyzão Impressyonyzta da Poezya Brazyleyra”, em que ele nota que, em cada fase histórica de nossa literatura, há poetas prestes a reescrever uma nova literatura pela quebra e pela novidade de uma nova utopia: “[...] a destruição da utopia é cantada por Basílio da Gama no poema épico

\footnotetext{
${ }^{118}$ Glauber Rocha, “Santos dos Luiz Paulino 80”, em Revolução do cinema novo, 2004, p. 490.

${ }^{119}$ Cf. Glauber Rocha, "Goal de Figueiredo", Folha de S. Paulo, São Paulo (SP), 17 jun. 1978, p. 30.

${ }^{120}$ Glauber Rocha, “Salles de Almeida Luiz Francisco 80”, em Revolução do cinema novo, 2004, p. 491.

${ }^{121}$ Glauber Rocha, "Revolução do Brazyl”, s/d. [Datiloscrito, 4 páginas, inédito, Tempo Glauber, Rio de Janeiro $(\mathrm{RJ})]$.
} 
didático o 'Uraguai' [...] Thomaz Antonio Gonzaga teoriza a Utopia e a põe em prática revolucionária" ${ }^{122}$.

Por fim, quanto à Lygia Pape, que Glauber conhecera desde os anos finais da década de 1950, seu texto transita da utopia para os movimentos de marco histórico em nossa cultura. É desse modo que o autor de Revolução sublinha a "Reação Concretista", referência ao que tudo indica aos neoconcretos do Rio. Como não podia deixar de ressaltar a "Revolução do cinema novo" é sublinhada como fim do percurso. Diga-se, em caráter ambíguo, afinal não temos certeza se a referência se dá ao movimento ou ao livro que ele acabara de conceber.

Glauber com os fragmentos ligados a cada uma das trajetórias foi perspicaz e bastante estratégico. Enquanto fixava os principais nomes ligados ao nosso cinema, defendia certos princípios que, quer queiram ou não, demonstravam que a história de Revolução do cinema novo também era parte da história de nossa própria cultura. Naquele momento, talvez havia conseguido a proeza de retirar de vez o mundo do cinema, o seu cinema, de algum gueto dependente. Em seu tabuleiro, ele havia posto mocinhos, inimigos, feito algumas intrigas de enredo, criado um tempo e espaço apropriados, tudo isso para um roteiro de filme, conforme afirmou no prefácio para o seu livro, sem o "clássico happy end do último capítulo" ${ }^{\prime 23}$.

Convém notar que Glauber não retratou em título específico sua trajetória; o líder ficou sem abordagem própria. Talvez porque já considerasse que Revolução do cinema novo havia se tornado muito mais autobiográfico do que ele mesmo previra - um livro de confissão. Pratos no ar. Mira apontada. Na mosca. Era uma de suas últimas pontarias no território nacional. Revolução era, a um só tempo, seu tiro de misericórdia e maledicência. Errara os pratos, mas abatera um pássaro, em pleno voo.

\footnotetext{
${ }^{122}$ Glauber Rocha, "Revyzão Impressyonyzta da Poezya Brazyleyra", s/d. [Datiloscrito, 23 páginas, inédito, Tempo Glauber, Rio de Janeiro (RJ)].

${ }^{123}$ Glauber Rocha, "Prefácio de uma Revolução", em Revolução do cinema novo, 2004, p. 36.
} 


\section{Referências Bibliográficas}

\section{Livros, teses e artigos}

ADORNO, Theodor W. Notas de literatura I. Tradução e apresentação: Jorge M. B. de Almeida. São Paulo: Duas Cidades / Editora 34, 2003.

AMADEI, Yolanda. "Yanka Rudzka”. In: COELHO, Maria Cristina Barbosa Lopes; XAVIER, Renata Ferreira (Orgs.). Memória da Dança em São Paulo. São Paulo: Centro Cultural São Paulo, 2007.

AVELAR, José Carlos. A ponte clandestina. Teorias do cinema na América Latina. Rio de Janeiro/São Paulo: Ed.34/EDUSP, 1995.

BERNARDET, Jean-Claude. Brasil em tempo de cinema: ensaio sobre cinema brasileiro. 3.ed. Rio de Janeiro: 1978.

BERNARDET, Jean-Claude. Historiografia clássica do cinema brasileiro. São Paulo: Annablume, 1995.

BOSI, Alfredo. Literatura e resistência. São Paulo: Companhia das Letras, 2002.

BOURDIEU, Pierre. A distinção. São Paulo: Edusp, 2007.

BOURDIEU, Pierre. A economia das trocas simbólicas. São Paulo: Perspectiva, 2007.

BOURDIEU, Pierre. A produção da crença. Porto Alegre: Zouk, 2008.

BOURDIEU, Pierre. As regras da arte. São Paulo: Companhia das Letras, 1996.

BOURDIEU, Pierre. Esquisse d'une theorie de la pratique. Paris: Droz, 1972.

BOURDIEU, Pierre. O amor pela arte. 2. ed. São Paulo: Edusp; Porto Alegre: Zouk, 2007.

BOURDIEU, Pierre. Os usos sociais da ciência. São Paulo: Edunesp, 2004.

BOURDIEU, Pierre. Razões práticas. Campinas: Papirus, 1996.

BRECHT, Bertolt. Estudos sobre teatro. Rio de Janeiro: Nova Fronteira, 1978.

BRITO, Ronaldo. Neoconcretismo: vértice e ruptura do projeto construtivo brasileiro. São Paulo: Cosac Naify, 1999. 
BUENO, Alexei. Glauber Rocha: mais fortes são os poderes do povo!. Rio de Janeiro: Manati, 2003.

CAMPOS, Haroldo de, "Ruptura nos gêneros na literatura latino-americana”. In: MORENO, César Fernández. América Latina em sua literatura. São Paulo: Perspectiva, 1979.

CAMPOS, Haroldo. “Uma poética da radicalidade”. In: ANDRADE, Oswald. Pau-brasil. 5 ed. São Paulo: Editora Globo, 2000.

CANDIDO, Antonio et all. A personagem de ficção. 9 ed. São Paulo: Perspectiva, 1998.

CANDIDO, Antonio. "Radicalismos”. In: CANDIDO, Antonio. Vários escritos. São Paulo: Ouro sobre Azul, 2004.

CANDIDO, Antonio. A educação pela noite. São Paulo: Ouro sobre Azul, 2006.

CANDIDO, Antonio. Formação da literatura brasileira: momentos decisivos, 1750-1880. Belo Horizonte: Itatiaia, 2000.

CANDIDO, Antonio. "Limites da biografia". In: Suplemento Literário d'O Estado de S. Paulo. 24 de janeiro de 1959, p.1.

CANDIDO, Antonio. Literatura e sociedade. 8 ed. São Paulo: T.A. Queiroz, 2000.

CANDIDO, Antonio. Noções de análise histórico-literária. São Paulo: Associação Editorial Humanitas, 2005.

CANDIDO, Antonio. Perenidade da biografia. In: Suplemento Literário d'O Estado de $S$. Paulo. 28 de fevereiro de 1959, p.1.

CARDOSO, Maurício. O cinema tricontinental de Glauber Rocha: política, estética e revolução (1969-1974). 285 f. Tese (Doutorado em História Social) - Faculdade de Filosofia, Letras e Ciências Humanas da Universidade de São Paulo, São Paulo, 2007.

CARPEAUX, Otto Maria. História da literatura ocidental. 2 ed. Rio de Janeiro: Alhambra, 1978.

CARPENTIER, Alejo. Literatura e consciência política na América Latina. São Paulo: Global, 1969.

CARVALHO, Maria do Socorro Silva. Imagens de um tempo em movimento. Salvador: Editora da UFBA, 1999.

CHAUI, Marilena. Seminários. São Paulo: Brasiliense, 1984.

CONSTANTINI, Eduardo F.; GOLDMAN, Ana; CANGI, Adrián. Glauber Rocha: del hambre al sueño. Buenos Aires: Malba, 2004.

COSTA, Flávio Moreira da (Org.). Cinema moderno, cinema novo. Rio de Janeiro: José Álvaro, 1966. 
CUNHA, Euclides. Diário de uma expedição. Organização de Walnice Nogueira Galvão. São Paulo: Companhia das Letras, 2001.

DEL PICHIA, Pedro. "Veneza dá os Leões, e Glauber faz comício". Folha de S. Paulo, São Paulo (SP), set. 1980.

DEL PICHIA, Pedro; MURANO, Virginia (Orgs.). Glauber, o leão de Veneza. São Paulo: Editora Escrita, 1982

DIAS, André Luís Mattedi. “A universidade e a modernização conservadora na Bahia: Edgard Santos, o Instituto de Matemática e Física e a Petrobras". Revista da SBHC, Rio de Janeiro (RJ), v. 3, n. 2, jul./dez. 2005, p. 126.

ELIAS, Norbert. A peregrinação de Watteau à ilha do amor. Rio de Janeiro: Zahar, 2005.

ELIAS, Norbert. A sociedade de corte. Rio de Janeiro: Zahar, 2001.

FABRIS, Mariarosaria. Nelson Pereira do Santos. um olhar neo-realista? São Paulo: Edusp, 1994.

FERNANDES, Florestan. A revolução burguesa do Brasil: ensaios de interpretação sociológica. São Paulo: Editora Globo, 2006 [1. ed.: 1976].

FERNANDES, Florestan. Sociedade de classes e subdesenvolvimento. São Paulo: Global, 2008 [1. ed.: 1968].

FERRARI, Marco. Ti ricordi Glauber. Palermo: Sellerio, 1999.

FERRO, Sérgio. “Arquitetura Nova”. Teoria e Prática, São Paulo (SP), n. 1, 1967, pp. 3-15.

FERRO, Sérgio; LEFÈVRE, Rodrigo. "Proposta inicial para um debate: possibilidade de atuação”. In: FERRO, Sérgio. Arquitetura e trabalho livre. São Paulo: Cosac Naify, 2006.

FIGUERÔA, Alexandre. Cinema Novo: a onda do jovem cinema e sua recepção na França. Campinas, Papirus, 2004.

FRANCIS, Paulo. "Glauber, o leão de Veneza". Folha de São Paulo, São Paulo (SP), 19 set. 1980.

FREYRE, Gilberto. Casa-grande \& senzala. Introdução à história da sociedade patriarcal no Brasil - 1. 39 ed. Rio de Janeiro: Record, 2000. [1. ed.: 1933].

GALVÃO, Walnice Nogueira. "Musas sob assédio”. Folha de S. Paulo (suplemento Mais.), São Paulo (SP), 17 mar. 2002, pp. 5-11.

GATTI, André. “Cineclube”. In: RAMOS, Fernão; MIRANDA, Luiz Felipe. Enciclopédia do cinema brasileiro. 2. ed. São Paulo: Editora Senac, 1997.

GERBER, Raquel. O mito da civilização Atlântica: Glauber Rocha, cinema, política e a estética do inconsciente. Petrópolis: Vozes, 1982. 
GOMES, João Carlos Teixeira. Camões contestador e outros ensaios. Salvador: Fundação Cultural do Estado da Bahia, 1979.

GOMES, João Carlos Teixeira. Glauber Rocha, esse vulcão. Rio de Janeiro: Nova Fronteira, 1997.

GOMES, Paulo Emílio Sales. Cinema: trajetória no subdesenvolvimento. São Paulo: Paz e Terra, 1996.

GOMES, Paulo Emílio Sales. Crítica de Cinema no Suplemento Literário. V.1 e V.2. Rio de Janeiro: Paz e Terra, 1981.

GRAMSCI, Antonio. Literatura e vida social. 2 ed. Rio de Janeiro: Civilização Brasileira, 1978.

GUEVARA, Alfredo. Um sueño compartido. Madrid (Espanha): Iberoautor, 2002.

HOLANDA, Sérgio Buarque. Raízes do Brasil. Edição comemorativa 70 anos. São Paulo: Companhia das Letras, 2006 [1. ed.: 1936]..

JOHNSON, Randal; STAM, Robert. Brazilian cinema. New York: Columbia University Press, 1995.

LABAKI, Amir. "Memórias de uma geração" [entrevista com Louis Malle]. Folha de S. Paulo (suplemento Mais.), São Paulo (SP), 21 jan. 1996.

LINS, Álvaro; CARPEAUX, Otto Maria; THOMPSON, Franklin M. José Lins do Rêgo. Rio de Janeiro: Ministério da Educação e Saúde, 1952.

LINS, Osman. Lima Barreto e o Espaço Romanesco. São Paulo: Ática, 1976.

LISBOA, Fátima Sebastiana Gomes. Un artiste intellectuel: Glauber Rocha et l'utopie du Cinema Novo (1955-1971). Lille: Presses Universitaire du Septentrion, 2002.

LUKÁCS, Georg. A teoria do romance. Tradução, posfácio e notas: José Marcos Mariani de Macedo. São Paulo: Duas Cidades / Editora 34, 2000.

MACIEL, Luis Carlos. "Dialética da violência”. In: VÁRIOS AUTORES, Deus e o Diabo na terra do sol. Rio de Janeiro: Civilização Brasileira, 1965.

MAIA, Vasconcelos; ARAUJO, Nelson de. Panorama do conto baiano. Salvador: Imprensa Oficial da Bahia, Livraria Progresso Editora, 1959.

MARTINS, Maurício Vieira, "Bourdieu e o fenômeno estético", Revista Brasileira de Ciências Sociais, v. 19, n. 56, out. 2004.

MASSA, Jean-Michel. A juventude de Machado de Assis. São Paulo: Edunesp, 2009.

MATTA, João Eurico. Ângulos. a vigência de uma revista universitária. Salvador: Centro de Estudos Baianos da Universidade Federal da Bahia, 1987. 
MEIRELES, Cecília. Mar Absoluto e outros poemas. In: MEIRELES, Cecília. Obra Poética. Rio de Janeiro: Aguilar, 1967.

MICELI, Sergio. Intelectuais à brasileira. São Paulo: Companhia das Letras, 2001.

MICELI, Sergio. "Bourdieu e a renovação da sociologia contemporânea da cultura". Tempo Social, São Paulo (SP), v. 15, n. 1, abr. 2003.

MICELI, Sergio. "Introdução: a força do sentido". In: BOURDIEU, Pierre. A economia das trocas simbólicas. São Paulo: Perspectiva, 2007.

MONZANI, Josette Maria Alves de Souza. Gênese de Deus e o Diabo na terra do sol. São Paulo: Annablume/ Fapesp, 2005.

MORENO, César Fernández. América Latina em sua literatura. São Paulo: Perspectiva, 1979.

MOTA, Carlos Guilherme. Ideologia da cultura brasileira (Pontos de partida para uma revisão histórica). 9. ed. São Paulo: Ática, 1994.

MOTA, Regina. A épica eletrônica de Glauber. um estudo sobre cinema e TV. Belo Horizonte: ed.UFMG, 2001.

NEVES, Sheila Grecco de Oliveira. Dois, diversos. alegorias do Brasil em Guimarães Rosa e Glauber Rocha. Tese de doutorado (Letras). Faculdade de Filosofia, Letras e Ciências Humanas, Universidade de São Paulo, 2005.

ORTIZ, Renato (Org.). A sociologia de Pierre Bourdieu. São Paulo: Olho d’Água, 2003.

ORTIZ, Renato. "A porosidade das fronteiras nas Ciências Sociais”. In: ORTIZ, Renato (Org.). A sociologia de Pierre Bourdieu. São Paulo: Olho d’Água, 2003.

PAULA FREITAS, Ayêska; LOBO, Júlio César. Glauber: a conquista de um sonho, os anos verdes. Belo Horizonte: Dimensão, 1995.

PIERRE, Sylvie. Glauber Rocha: textos e entrevistas com Glauber Rocha. Campinas: Papirus, 1996.

PRADO JR., Caio. A revolução brasileira. São Paulo: Brasiliense, 1966.

RAMA, Ángel. "Dez problemas para o romancista latino-americano". In: AGUIAR, Flávio; VASCONCELOS, Sandra Guardini T.. Ángel Rama: literatura e cultura na América Latina. São Paulo: Edusp, 2001.

RAMA, Ángel. "Nossa América". In: RAMA, Ángel. Literatura, cultura e sociedade na América Latina. Organização Pablo Rocca. Belo Horizonte: Editora da UFMG, 2008.

REGO, José Lins. Cangaceiros. Rio de Janeiro: Jose Olympio, 1976.

REGO, José Lins. Presença do Nordeste na literatura. Rio de Janeiro: Departamento de Imprensa Nacional, 1957. 
RISÉRIO, Antonio. Avant-garde na Bahia. São Paulo: Instituto Lina Bo e P.M. Bardi, 1995.

ROCHA, Glauber. “O Diretor (ou o Autor)”. In: COSTA, Flávio Moreira da (Org.). Cinema moderno, cinema novo. Rio de Janeiro: José Álvaro, 1966. pp. 51-52.

ROCHA, Glauber. Cartas ao mundo. Organização de Ivana Bentes. São Paulo: Companhia das Letras, 1997.

ROCHA, Glauber. O século do cinema. São Paulo: Cosac Naify, 2006.

ROCHA, Glauber. Poemas eskolhydos de Glauber Rocha. Rio de Janeiro: Alhambra, 1989.

ROCHA, Glauber. Revisão crítica do cinema brasileiro. São Paulo: Cosac Naify, 2003.

ROCHA, Glauber. Revolução do Cinema Novo. São Paulo: Cosac Naify, 2004.

ROCHA, Glauber. Riverão Sussuarana. Rio de Janeiro: Record, 1977.

ROCHA, Glauber. Roteiros do Terceyro Mundo. Organização de Orlando Senna. Rio de Janeiro: Alhambra/Embrafilme, 1985.

ROCHA, Glauber. "Uma estética da fome”. Revista Civilização Brasileira. Rio de Janeiro (RJ), ano 1, n. 3, jul. 1965, pp. 165-70.

SANTANA, Jussilene. Impressões modernas/A má consciência teatral: compreensão e debate sobre teatro na cobertura dos jornais A Tarde e Diário de Notícias entre 1956 e 1961. 216 f. Dissertação (Mestrado em Artes Cênicas) - Escola de Teatro, Universidade Federal da Bahia, Salvador, 2006.

SANTOS, Edgard. Afirmaçôes e testemunhos. Salvador: UFBA, 1971.

SANTOS, Geraldo. Loucos, poetas, amantes. Rio de Janeiro: São José, 1956.

SAPIRO, Gisele. "Elementos para uma história do processo de autonomização: o exemplo do campo literário francês”, Tempo Social, São Paulo (SP), v. 16, n. 1, jun. 2004.

SARACENI, Paulo César. Por dentro do cinema: minha viagem. Rio de Janeiro: Nova Fronteira, 1993.

SARNO, Geraldo. Glauber Rocha e o cinema latino americano. Rio de Janeiro: Centro Interdisciplinar de Estudos Contemporâneos, Escola de Comunicação UFRJ: Rio Filme, Prefeitura do Rio, 1994.

SCHWARZ, Roberto. Ao vencedor as batatas. São Paulo: Editora 34, 2000.

SCHWARZ, Roberto. Cultura e política. São Paulo: Paz e Terra, 2005.

SCHWARZ, Roberto. Sequências brasileiras. São Paulo: Companhia das Letras, 1999. 
SHOHAT, Ella; STAM, Robert. Crítica da imagem eurocêntrica. São Paulo: Cosac Naify, 2006.

SILVEIRA, Walter. A História do Cinema Vista da Província. Salvador: Fundação. Cultural do Estado da Bahia, 1978.

STAM, Robert. Tropical multiculturalism: a comparative history of race in Brazilian cinema and culture. Durham: Duke University Press, 1997.

SÜSSEKIND, Flora. Literatura e vida literária: polêmicas, diários \& retratos. Belo Horizonte: Editora UFMG, 2004.

SZONDI, Peter. Teoria do drama moderno: 1880-1950. São Paulo: Cosac Naify, 2001.

VALENTINETTI, Claudio. Glauber, um olhar europeu. São Paulo: Instituto Lina Bo e P.M. Bardi; Rio de Janeiro: Prefeitura do Rio, 2002.

VÁRIOS AUTORES. Glauber Rocha. 2 ed. São Paulo: Paz e Terra, 1991

VASCONCELLOS, Gilberto Felisberto. Glauber Pátria Rocha Livre. São Paulo: Senac, 2001.

VEIGA, Benedito. Memória da vida literária baiana: década de 60 (indexação do Suplemento Dominical do Diário de Notícias: 1956-1971). Salvador: Uneb; Quarteto, 2003.

VENTURA, Tereza. A poética polytica de Glauber Rocha. Rio de Janeiro: Funarte, 2000.

VIANY, Alex (Org.). O processo do cinema novo. Rio de Janeiro: Aeroplano, 1999.

WACQUANT, Loïc. "Habitus". In: International Encyclopedia of Economic Sociology, Londres: Routledge, 2005.

WILLIAMS, Raymond. Tragédia moderna. São Paulo: Cosac Naify, 2002.

XAVIER, Ismail. "Prefácio". In: ROCHA, Glauber. Revisão crítica do cinema brasileiro. São Paulo: Cosac Naify, 2003.

XAVIER, Ismail. "Prefácio". In: ROCHA, Glauber. Revolução do Cinema Novo. São Paulo: Cosac Naify, 2004.

XAVIER, Ismail. Alegorias do subdesenvolvimento: Cinema Novo,Tropicalismo, Cinema Marginal. São Paulo: Brasiliense, 1993.

XAVIER, Ismail. O cinema brasileiro moderno. São Paulo: Paz e Terra, 2001.

XAVIER, Ismail. Sertão Mar. Glauber Rocha e a estética da fome. São Paulo: Brasiliense, 1983. 


\section{Periódicos com colaboração de Glauber*}

${ }^{*}$ na lista a seguir, constam os artigos de Glauber utilizados em cada capítulo da tese e estão organizados segundo sua ordem de aparição neste estudo. Entre os colchetes, ao final de cada referência, encontram-se as páginas para sua localização na "Kynoperzpektyva de Glauber Rocha: seleção de textos”, presente no segundo volume.

\section{Capítulo I}

Glauber Rocha, "Romance de José Lins do Rêgo", Mapa, Salvador (BA), ano 1, n. 2, 1957, pp. 58-77. [Segundo volume: pp. 319-338].

Glauber Rocha, "O western - uma introdução ao estudo do gênero e do herói", Mapa, Salvador (BA), ano 1, n. 1, 1957, pp. 18-19. [Segundo volume: pp. 339-344].

Glauber Rocha, "Burguês não é o herói que saca a pistola e enfrenta a morte no quente meiodia”, Diário de Notícias, Salvador (BA), 10-11 jan. 1960, p. 3. [Segundo volume: p. 345].

Glauber Rocha, "Raices mexicanas de Benito Alazraki", Mapa, Salvador (BA), ano 2, n. 3, ago. 1958, s/p. [Segundo volume: pp. 403-408].

Glauber Rocha, "Romance brasileiro - 57", Angulos, Salvador (BA), ano VII, n. 12, dez. 1957, pp. 128-136. [Segundo volume: pp. 346-354].

Glauber Rocha, "Velas. Calasans Neto e Paulo Gil", Ângulos, Salvador (BA), ano VIII , n. 13, jul. 1958, pp. 144-145. [Segundo volume: pp. 355-356].

Glauber Rocha, "De cinestética", Angulos, Salvador (BA), ano VIII , n. 13, jul. 1958, pp. 115127. [Segundo volume: pp. 430-442].

Glauber Rocha, "Filme experimental: um tempo fora do tempo", Angulos, Salvador (BA), ano IX, n. 13, maio 1959, p. 103-106. [Segundo volume: pp. 443-446].

\section{Capítulo II}

Glauber Rocha, "Glória feita de sangue (I)", Jornal da Bahia, Salvador (BA), 04 nov. 1958, p.

3. [Segundo volume: pp. 447].

Glauber Rocha, "Glória feita de sangue (II)", Jornal da Bahia, Salvador (BA), 05 nov. 1958, p.

3. [Segundo volume: pp. 448-450]. 
Glauber Rocha, “As virgens de Salém (I)", Jornal da Bahia, Salvador (BA), 16 out. 1958, p. 3. [Segundo volume: pp. 451].

Glauber Rocha, “As virgens de Salém (II)", Jornal da Bahia, Salvador (BA), 17 out. 1958, p. 3. [Segundo volume: pp. 452-453].

Glauber Rocha, "Cinema nacional sabotado", Jornal da Bahia, Salvador (BA), 15 nov. 1958, p. 3. [Segundo volume: pp. 360].

Glauber Rocha, "Nota breve: o intelectual e o cinema", Jornal da Bahia, Salvador (BA), 25-26 jan. 1959, p. 3. [Segundo volume: pp. 454-455].

Glauber Rocha, "Indústria de cinema na Bahia", Jornal da Bahia, Salvador (BA), 14 dez. 1958, p. 3. [Segundo volume: pp. 359].

Glauber Rocha, “'Redenção' - primeiro filme baiano”, Jornal da Bahia, Salvador (BA), 09 out. 1958, p. 3. [Segundo volume: pp. 358].

Glauber Rocha, "Notas e comentários de cinema na Bahia", Jornal da Bahia, Salvador (BA), 04 dez. 1958, p. 3. [Segundo volume: pp. 357].

Glauber Rocha, "Rio, Zona Norte", Jornal da Bahia, Salvador (BA), 18 dez. 1958, p. 3. [Segundo volume: pp. 310].

Glauber Rocha, "Importância de Nelson Pereira dos Santos", Jornal da Bahia, Salvador (BA), 21-22 dez. 1958, p. 3. [Segundo volume: pp. 308-309].

Glauber Rocha, "Rio, Zona Norte (II)", Jornal da Bahia, Salvador (BA), 25 dez. 1958, p. 3. [Segundo volume: pp. 311].

Glauber Rocha, "reunião (E Sonia) 1", Diário de Notícias, Salvador (BA), 19-20 mar. 1961, p. 1. [Segundo volume: pp. 364].

Glauber Rocha, "David \& Ubaldo \& Noenio", Diário de Notícias, Salvador (BA), 26-27 mar. 1961, pp. 1-2. [Segundo volume: pp. 361-363].

Glauber Rocha, "Inconsciência \& inconseqüência da atual cultura baiana”, Diário de Notícias, Salvador (BA), 05 fev. 1961, p. 1. [Segundo volume: pp. 369-376].

Glauber Rocha, "Eis a fogueira, poeta!", Diário de Notícias, Salvador (BA), 28-29 maio 1961, p. 5. [Segundo volume: pp. 367-368].

Glauber Rocha, "Sobre 'ângulos' \& outros bichos”, Diário de Notícias, Salvador (BA), 18-19 jun. 1961, p. 5. [Segundo volume: pp. 365-366].

Glauber Rocha, "Experiência 'Barravento': confissão sem moldura”, Diário de Notícias, Salvador (BA), 25-26 dez. 1960, p. 6. [Segundo volume: pp. 312].

Glauber Rocha, "Luz Atlântica, 1962", Diário de Notícias, Salvador (BA), 31 dez. 1961, s/p. [Segundo volume: pp. 456-457]. 


\section{Capítulo III}

Glauber Rocha, "Orfeu metafísica de favela", Suplemento Dominical do Jornal do Brasil (SDJB), Rio de Janeiro (RJ), 24 out. 1959, p. 1. [Segundo volume: pp. 313-316].

Glauber Rocha, "Sete pontos: cinema brasileiro", Suplemento Dominical do Jornal do Brasil (SDJB), Rio de Janeiro (RJ), 5 abr. 1959, p. 5. [Segundo volume: pp. 401].

Glauber Rocha, "Cinema: operação Nordeste”, Suplemento Dominical do Jornal do Brasil (SDJB), Rio de Janeiro (RJ), 12 dez. 1959, p. 5. [Segundo volume: pp. 385-388].

Glauber Rocha, “'Bossa Nova' no cinema brasileiro”, Suplemento Dominical do Jornal do Brasil (SDJB), Rio de Janeiro (RJ), 12 mar. 1960, p. 5. [Segundo volume: pp. 389-391].

Glauber Rocha, "O processo cinema", Suplemento Dominical do Jornal do Brasil (SDJB), Rio de Janeiro (RJ), 6 maio 1961, p. 3. [Segundo volume: pp. 377-379].

Glauber Rocha, “Atenção, Paulo Francis”, Suplemento Dominical do Jornal do Brasil (SDJB), Rio de Janeiro (RJ), 14-15 jan. 1961, p. 7. [Segundo volume: pp. 392-393].

Glauber Rocha, “Tope a parada, 'Mr.' Francis”, Suplemento Dominical do Jornal do Brasil (SDJB), Rio de Janeiro (RJ), 11 fev. 1961, p. 4. [Segundo volume: pp. 394-400].

Glauber Rocha, "Cinema novo e cinema livre”, Suplemento Dominical do Jornal do Brasil (SDJB), Rio de Janeiro (RJ), 8 jul. 1961, p. 7. [Segundo volume: pp. 380-382].

Glauber Rocha, "Arraial, cinema novo e câmara na mão", Suplemento Dominical do Jornal do Brasil (SDJB), Rio de Janeiro (RJ), 12 ago. 1961, p. 4. [Segundo volume: pp. 383-384].

Glauber Rocha, "Contra direitas e esquerdas o nosso cinema segue em frente”, Última Hora, Rio de Janeiro (RJ), 27 fev. 1970, s/p. [Segundo volume: pp. 411-413].

Glauber Rocha, "O barato do Lacerda (não ficção, interartigo, duplifarsa, óleo de rícino, ensaitixix, etc.)”, O Pasquim, Rio de Janeiro (RJ), 05-11 mar. 1970. [Segundo volume: pp. 409-410].

Glauber Rocha, "Os mortos do primavera", O Pasquim, Rio de Janeiro (RJ), 29 fev. 1972. [Segundo volume: pp. 317]. 


\section{Capítulo IV}

Glauber Rocha, "Vatapá no ventilador", Pasquim, Rio de Janeiro (RJ), out. 1975, s/p. [Segundo volume: pp. 420-423].

Glauber em M. Pontes, "Deus e o Diabo no tempo do exílio (Glauber Rocha se explica, desabafa, faz história e até futurologia)", Jornal do Brasil, Rio de Janeiro (RJ), 13 dez. 1975, p. 10. [Segundo volume: pp. 481-485].

Glauber Rocha, "Goal de Figueredo", Folha de S. Paulo, São Paulo (SP), 17 jun. 1978, p. 30. [Segundo volume: pp. 414-417].

Glauber Rocha, "Fomaluf", Folha de S. Paulo, São Paulo (SP), 8 jul. 1978, p. 26. [Segundo volume: pp. 418].

Glauber Rocha, "Folhynhaz da Prymavera", Folha de S. Paulo, São Paulo (SP), 26 ago. 1978, p. 30. [Segundo volume: pp. 419].

Glauber Rocha em Maria Lúcia Rangel, "Um incômodo cineasta do terceiro mundo", Jornal do Brasil, Rio de Janeiro (RJ), 28 maio 1977, p. 10. [Depoimento]. [Segundo volume: pp. 502-505].

Glauber Rocha em Lúcia Rito, “Não me exijam coerência”, Veja, São Paulo (SP), 8 set. 1976, p. 4. [Depoimento]. [Segundo volume: pp. 497-501].

Glauber Rocha em Paulo Francis, "Glauber Rocha: entrevista concedida a Paulo Francis", Status, São Paulo (SP), mar. 1975, pp. 13-17. [Depoimento]. [Segundo volume: pp. 474480].

Glauber Rocha em Mary Ventura, "Glauber Rocha de volta", Jornal do Brasil, Rio de Janeiro (RJ), 26 jun. 1976, p. 1. [Depoimento]. [Segundo volume: pp. 486-489].

Glauber Rocha, em Narciso Lobo, "Nem Lênin, Nem Mao, nem Stalin, nem mesmo Machado de Assis”, Movimento, São Paulo (SP), 19 jul. 1976, p. 19. [Segundo volume: pp. ]. [Segundo volume: pp. 493-496].

Glauber Rocha, "Querem me matar (ou, votem na Arena)", O Pasquim, Rio de Janeiro (RJ), 13-19 ago. 1976, p. 14. [Segundo volume: pp. 424-428].

Glauber Rocha, “'O Guarany’ e 'Dom Casmurro’ ou a competição entre Iracema e Capitu pelo título de Misse Brazyl”, Jornal do Brasil, Rio de Janeiro (RJ), 6 set. 1976, p. 10. [Segundo volume: pp. 466-470].

Glauber Rocha, "Limite", Folha de S. Paulo, São Paulo (SP), 3 jun. 1978, p. 30. [Segundo volume: pp. 458-459].

Glauber Rocha, "Kranyo", Folha de S. Paulo, São Paulo (SP), 10 jun. 1978, p. 32. [Segundo volume: pp. 460]. 
Glauber Rocha, "Makunayma (1)", Folha de S. Paulo, São Paulo (SP), 23 set. 1978, p. 32. [Segundo volume: pp. 461-463].

Glauber Rocha, "Makunayma - 2", Folha de S. Paulo, São Paulo (SP), 28 out. 1978, p. [Segundo volume: pp. 464-465].

Glauber Rocha, "Idade da Terra: um aviso aos intelectuais", Folha de S. Paulo, São Paulo (SP), 9 nov. 1980, p. 51. [Segundo volume: pp. 471-472].

Glauber Rocha em Isa Cambará, "'Contra dos donos oficiais da cultura”, Folha de S. Paulo, São Paulo (SP), 30 maio 1978, p. 37. [Depoimento]. [Segundo volume: pp. 506-508]. 